\author{
UNIVERSIDADE DE SÃO PAULO \\ FACULDADE DE FLOSOFIA, LETRAS E CIÊNCIAS HUMANAS \\ DEPARTAMENTO DE LETRAS MODERNAS \\ PROGRAMA DE PÓS-GRADUAÇÃO EM ESTUDOS LINGUÍSTICOS, \\ LITERÁRIOS E TRADUTOLÓGICOS EM FRANCÊS
}

ALINE HITOMI SUMIYA

O gênero multimodal tutorial em vídeo e suas contribuições no ensinoaprendizagem de francês como língua estrangeira por adolescentes

Versão Corrigida

São Paulo

2017 
UNIVERSIDADE DE SÃO PAULO

FACULDADE DE FLOSOFIA, LETRAS E CIÊNCIAS HUMANAS

DEPARTAMENTO DE LETRAS MODERNAS

PROGRAMA DE PÓS-GRADUAÇÃO EM ESTUDOS LINGUÍSTICOS,

LITERÁRIOS E TRADUTOLÓGICOS EM FRANCÊS

\title{
O gênero multimodal tutorial em vídeo e suas contribuições no ensino- aprendizagem de francês como língua estrangeira por adolescentes
}

\author{
Aline Hitomi Sumiya \\ Dissertação apresentada ao Programa de \\ Pós-Graduação em Estudos Linguísticos, \\ Literários e Tradutológicos em Francês do \\ Departamento de Letras Modernas da \\ Faculdade de Filosofia, Letras e Ciências \\ Humanas da Universidade de São Paulo, \\ para a obtenção do título de Mestre em \\ Letras, Língua e Literatura Francesa.
}

Orientadora: $\operatorname{Prof}^{\mathrm{a}} \mathrm{Dr}^{\mathrm{a}}$ Eliane Gouvêa Lousada

Versão Corrigida

São Paulo 
Nome: SUMIYA, Aline Hitomi

Título: O gênero multimodal tutorial em vídeo e suas contribuições no ensinoaprendizagem de francês como língua estrangeira por adolescentes

Dissertação apresentada ao Programa de Pós-Graduação em Estudos Linguísticos, Literários e Tradutológicos em Francês do Departamento de Letras Modernas da Faculdade de Filosofia, Letras e Ciências Humanas da Universidade de São Paulo, para a obtenção do título de Mestre em Letras, Língua e Literatura Francesa.

Aprovada em:

Banca Examinadora

Prof. Dr.: Instituição:

Julgamento: Assinatura:

Prof. Dr.: Instituição:

Julgamento: Assinatura:

Prof. Dr.: Instituição:

Julgamento: Assinatura: 
SUMIYA, A. H. O gênero multimodal tutorial em vídeos e suas contribuições para o ensino-aprendizagem de francês como língua estrangeira por adolescentes. 2017. 174 f. Dissertação (Mestrado) - Faculdade de Filosofia, Letras e Ciências Humanas. Universidade de São Paulo, São Paulo, 2016.

\section{RESUMO}

Esta dissertação tem como objetivo estudar o ensino-aprendizagem do francês como língua estrangeira por alunos adolescentes por meio da produção do gênero multimodal tutorial em vídeos, bem como verificar como os alunos desenvolveram as capacidades de linguagem por meio de uma sequência didática visando a produção desse gênero. Para realizá-la, nos embasamos, sobretudo, no quadro teórico-metodológico do Interacionismo Sociodiscursivo (ISD), tal como apresentado por Bronckart (1999, 2003, 2006, 2008, 2010) para a compreensão do agir humano por meio da linguagem e de seu consequente desenvolvimento. Assim, apoiamo-nos no modelo de análise textual do ISD para o estudo dos aspectos verbais presentes no gênero tutorial em vídeos. Como o gênero articula tanto os aspectos verbais como não verbais na sua construção de sentido, servimo-nos do quadro da Semiótica Sociointeracional proposta por Leal (2011) em que a autora propõe a união do quadro de análise do ISD com as categorias da Gramática do Design Visual (GDV) desenvolvida por Kress e Van Leeuwen (2006). Além disso, baseamo-nos nos estudos de Schneuwly e Dolz (2004/2012) sobre a utilização de gêneros textuais como instrumentos no ensino-aprendizagem e em Dolz, Pasquier e Bronckart (1993) sobre a noção de capacidades de linguagem. No que concerne ao campo da didática de línguas (maternas e estrangeiras), tivemos como aportes os estudos de outros teóricos da vertente do ISD (SCHNEUWLY; DOLZ, 2004/2012; CRISTOVÃO, 2014/2015; LOUSADA, 2014, MELÃO, 2014). Para ter o gênero como objeto de ensino, fizemos uma análise textual, o modelo didático, e posteriormente, elaboramos uma sequência didática e aplicamos em duas turmas de adolescentes. Após a aplicação, analisamos as produções iniciais e finais com a finalidade de saber se houve o desenvolvimento das capacidades de linguagem dos alunos. Para trazer mais indícios sobre o desenvolvimento, recuperamos excertos do diário de bordo da professora e das conversas gravadas dos alunos trocadas no momento da produção. Os resultados mostraram que houve um desenvolvimento significativo das capacidades de linguagem dos alunos, embora o gênero seja complexo por articular tanto elementos verbais como não verbais. Ademais, o gênero permitiu a aprendizagem dos alunos no que diz respeito a outros saberes não previstos no nosso estudo. Com esta pesquisa, esperamos ter trazido contribuições ao ensino-aprendizagem de línguas por meio de gêneros textuais, à multimodalidade e aos gêneros emergentes na era digital.

Palavras-chave: ensino-aprendizagem; FLE; gênero tutorial em vídeos; adolescentes. 
SUMIYA, A. H. The multimodal genre "video tutorial" and its contributions to the teaching and learning of French as a foreign language by teenage students. 2017. 174 f. Dissertação (Mestrado) - Faculdade de Filosofia, Letras e Ciências Humanas. Universidade de São Paulo, São Paulo, 2016.

\begin{abstract}
This dissertation's goal is to study the teaching and learning of French by teenage students through the production of the multimodal genre video tutorial, as well as verify how the students developed the language capacities through a didactic sequence that aimed at the production of this genre. Our research was based mainly on the SocioDiscursive Interactionism (SDI) theoretical and methodological framework as developed by Bronckart $(1999,2003,2006,2008,2010)$ to understand human acting through language and its consequent development. This research is also based on the SDI textual model analysis to study the verbal aspects found in the video tutorial genre. Since verbal and nonverbal aspects are combined in this genre, we used the SocioInteractionism Semiotics proposed by Leal (2011) in which the author suggests the union of the SDI analysis framework with the Grammar of Visual Design (GVD) developed by Kress and Van Leeuwen (2006). In addition, this research is based on the studies by Schneuwly and Dolz (2004/2012) about the use of textual genres as instruments in teaching and learning and about the concept of language capacities. Regarding the field of language didactics (L1 and L2), we also employed studies by SDI scholars (SCHNEUWLY; DOLZ, 2004/2012; CRISTOVÃO, 2014/2015; LOUSADA, 2014, MELÃO, 2014). In order to use the genre as an object of teaching, we analysed some texts and created a didactic model of it; then, we created a didactic sequence which we applied to two classes of teenage students. After applying it, we analysed the initial and final productions in order to discover if the students developed their language capacities. We had access to some excerpts of the teacher's journal and to some conversations recorded between the students when doing their productions to have more clues about the development. The results showed that the students developed substantially their language capacities, in spite of the complexity of the genre due to the articulation of so many verbal and nonverbal elements. Moreover, the genre allowed the students to learn other knowledge that were not foreseen in our study. With this research, we hope to bring contributions to the field of teaching and learning of languages through textual genres, of multimodality and of emergent genres of the digital era.
\end{abstract}

Key words: learning and teaching; FFL; video tutorial genre; teenage students. 
SUMIYA, A. H. Le genre multimodal tutoriel vidéo et ses contributions pour l'enseignement-apprentissage du Français Langue Etrangère aux adolescents. 2017. 174 f. Dissertação (Mestrado) - Faculdade de Filosofia, Letras e Ciências Humanas. Universidade de São Paulo, São Paulo, 2016.

\section{RÉSUMÉ}

Ce mémoire a pour but d'étudier l'enseignement-apprentissage du français comme langue étrangère à des adolescents à travers la production du genre multimodal tutoriel vidéo, ainsi que de vérifier comment les élèves ont développé leurs capacités langagières à partir d'une séquence didactique qui vise à la production de ce genre. Pour la réaliser, nous nous sommes basés surtout sur le cadre théorique-méthodologique de l'Interactionnisme Socio-discursif (ISD) de Bronckart (1999, 2003, 2006, 2008, 2010) pour la compréhension de l'agir humain à travers le langage et de son conséquent développement. Ainsi, nous nous sommes appuyés sur le modèle de l'analyse textuel de l'ISD pour les études des aspects verbaux présents dans le genre tutoriel vidéo. Etant donné que le genre a des aspects verbaux et aussi des aspects non verbaux et que le deux contribuent à la construction du sens, nous nous sommes servis du cadre de la Sémiotique Socio-interactionnelle proposé par Leal (2011) où l'auteure propose l'union du cadre de l'analyse de l'ISD avec des catégories de la Grammaire du Design Visuel (GDV) développée par Kress et Van Leeuwen (2006). De plus, nous nous sommes basés sur les études de Schneuwly et Dolz (2004/2012) sur l'utilisation des genres comme instrument dans l'enseignement-apprentissage et sur Dolz, Pasquier et Bronckart (1993) sur la notion des capacités langagières. En ce qui concerne le champ de la didactique des langues (maternelle et étrangères), nous avons eu comme base les études d'autres auteurs qui se basent sur l'ISD (SCHNEUWLY; DOLZ, 2004/2012; CRISTOVÃO, 2014/2015; LOUSADA, 2014, MELÃO, 2014). Pour utiliser le genre tutoriel vidéo comme objet d'enseignement, nous avons fait une analyse textuelle, le modèle didactique, et ensuite, nous avons élaboré une séquence didactique et nous l'avons appliquée dans deux groupes d'adolescents. Après l'application, nous avons analysé les productions initiales et finales pour savoir s'il y a eu le développement des capacités langagières des élèves. Pour avoir plus d'indices sur leur développement, nous avons récupéré les extraits du journal de bord de la professeure et des conversations enregistrées des élèves échangés au moment de la production. Malgré la complexité de ce genre, les résultats nous montrent qu'il y a eu un développement significatif des capacités langagières des élèves. En outre, le genre a permis l'apprentissage d'autres savoirs par les élèves qui n'étaient pas prévus dans notre étude. Avec cette recherche, nous espérons avoir apporté des contributions sur l'enseignement-apprentissage des langues à travers les genres textuels, sur la multimodalité et sur les études de genres provenant de l'ère informatique.

Mots-clés: enseignement-aprentissage; FLE; genre tutoriel vidéo; adolescents. 


\section{AGRADECIMENTOS}

À minha orientadora Eliane Gouvêa Lousada, pela dedicação. Por ter sido paciente neste meu percurso, por me proporcionar todo apoio e instrumentos necessários para o meu aprendizado e desenvolvimento.

Aos meus pais e meus irmãos, por sempre me apoiarem à cada decisão, pelo amor e carinho, por me fazerem acreditar que eu posso lutar pelos meus sonhos, ainda que pareçam inalcançáveis.

À professora Anise d'Orange Ferreira, pela leitura atenta ao meu trabalho, pela paciência e pelas contribuições no exame de qualificação. À professora Véronique Marie Braun Dahlet, pela sensibilidade, pelas reflexões glissantianas e pelos importantes comentários para a realização da minha pesquisa. Ao professor Joaquim Dolz, pela paciência, por me incentivar a continuar na caminhada acadêmica e pelas contribuições no meu estudo. Ao professor Olivier Dezutter, por ter me acolhido em terras québécoises e por ter me passado grandes ensinamentos, tanto sobre o amor à literatura quanto à minha pesquisa.

À minhas amigas Ana Paula Dias e Naiara Duarte, parceiras de angústias, crises existenciais e, principalmente, momentos de alegria, por me apoiarem e me fazerem rir.

Aos meus parceiros do grupo ALTER-AGE CNPq, por terem me acolhido e, por me mostrarem que, diferentemente do que todos dizem, a trajetória acadêmica não precisa ser solitária.

À Escola de Aplicação, à professora Sahsha Delatorre, aos alunos do primeiro ano, por não só fazerem parte desta pesquisa, mas também por terem me recebido com todo o carinho.

Aos meus alunos e ex alunos, pelos momentos de aprendizado, por fazerem do meu percurso acadêmico bem mais leve.

Aos meus amigos de Viçosa, que mesmo longe, estão sempre na torcida e presentes em minha vida. Aos meus colocs préférés, Adriana Silva, Nathalia dos Santos, Dario Marinkovic. Por me fazerem sentir sempre em casa, pelos conselhos, pelos abraços. Aos meu ex vizinho João Lennon, pelas cervejas no fim da noite, conversas com e sem sentido e risos de madrugada. 


\section{SUMÁRIO}

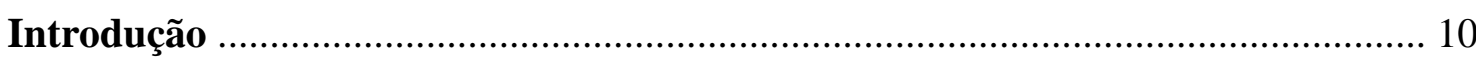

Objetivos e perguntas de pesquisa ………………………….................................. 14

Organização da dissertação ................................................................................. 15

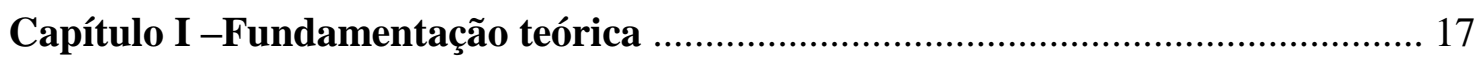

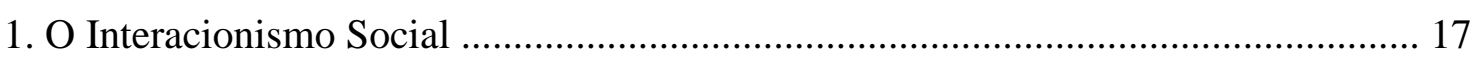

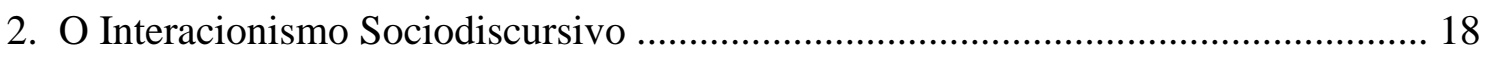

3. O instrumento psicológico e a Zona de Desenvolvimento Proximal ......................... 21

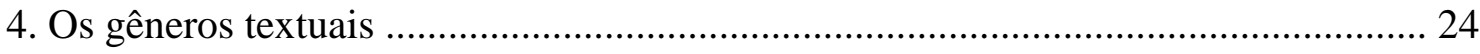

5. O Gênero tutorial em vídeos .............................................................................. 26

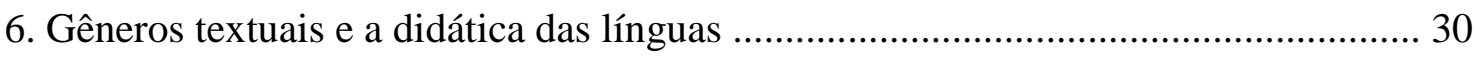

7. O Modelo Didático e a Sequência Didática ……………………………………….... 32

8. O modelo de análise textual do Interacionismo Sociodiscursivo ................................ 34

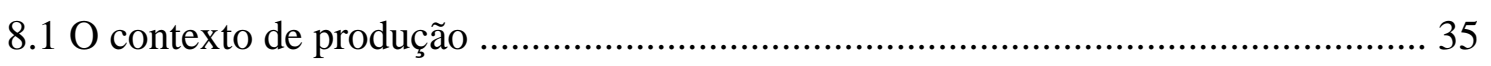

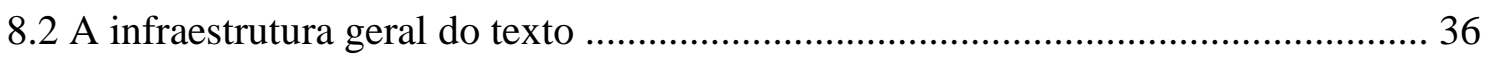

8.3 Os mecanismos de textualização .............................................................................. 39

8.4 Os mecanismos enunciativos ............................................................................. 40

9. A Gramática do Design Visual ........................................................................ 41

9.1 Os participantes da Gramática do Design Visual ..................................................... 43

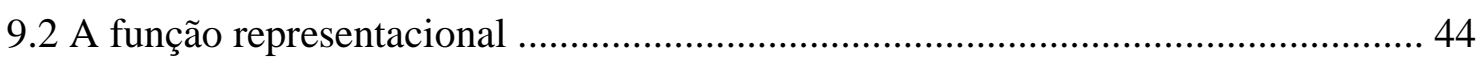

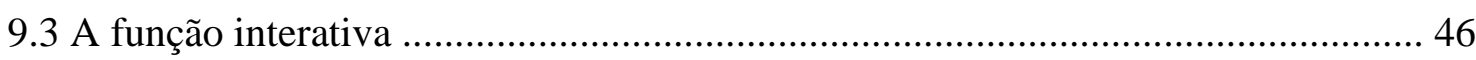

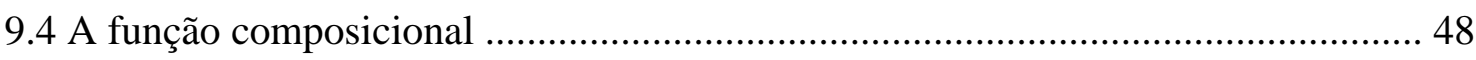

10 O modelo de análise Semiótico Sociointeracional ...................................................... 49

10.1 O contexto de produção, recepção e conteúdo temático ......................................... 49

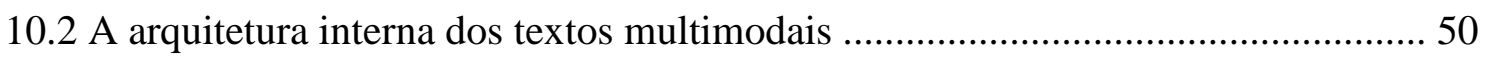

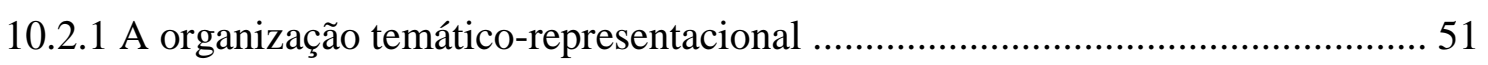

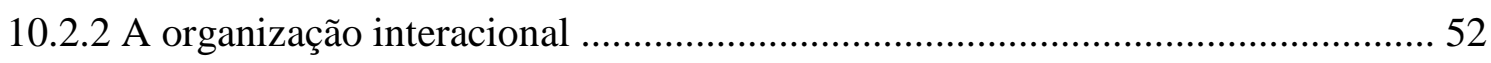

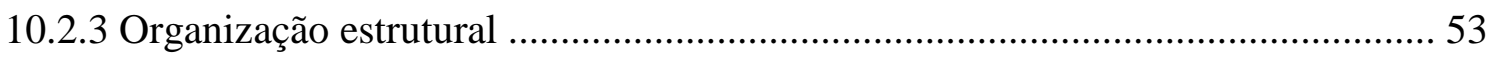

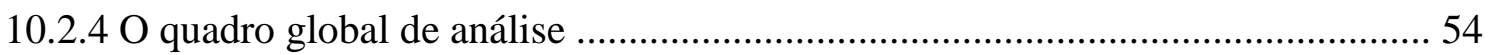




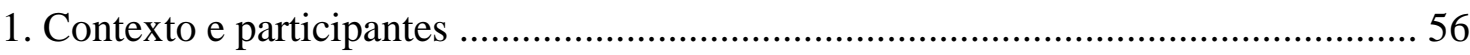

1.1. Escola de Aplicação da Faculdade de Educação da Universidade de São Paulo ... 57

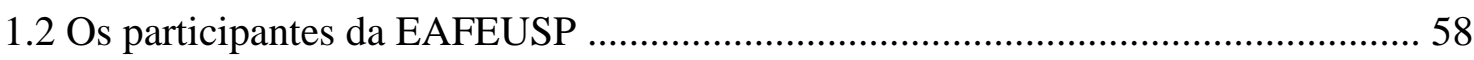

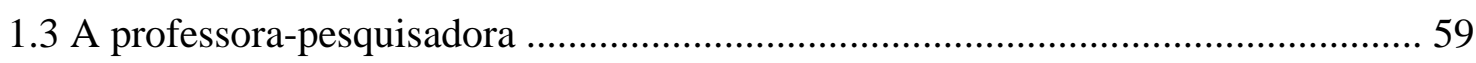

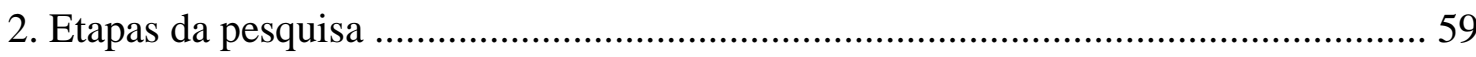

3 Os procedimentos para elaboração do modelo didático do gênero tutorial em vídeo 60

3.1 Os tutoriais selecionados para a elaboração do modelo didático ........................... 61

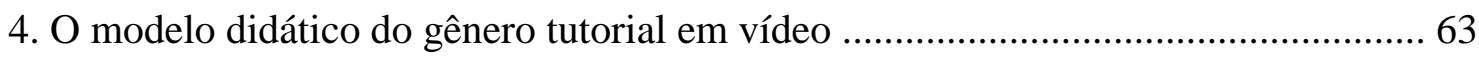

5. Os procedimentos para a elaboração da sequência didática ..................................... 80

6. A sequência didática do gênero tutorial em vídeo................................................. 81

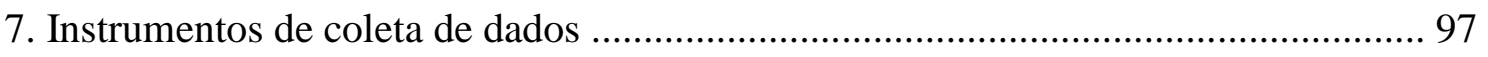

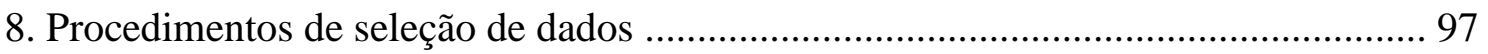

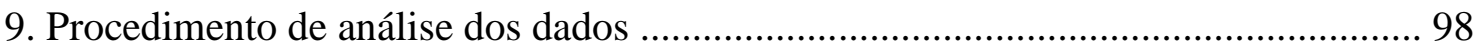

Capítulo III - Resultados das análises ............................................................... 101

1. Análise das produções dos tutoriais em vídeos dos alunos: Turma A ..................... 104

2. Análise das produções dos tutoriais em vídeos dos alunos: Turma B .................... 116

3. Discussão das análises e resultados ..................................................................... 132

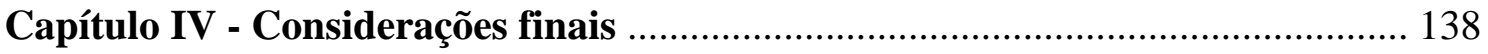

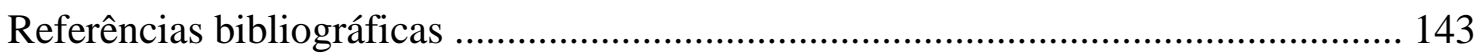

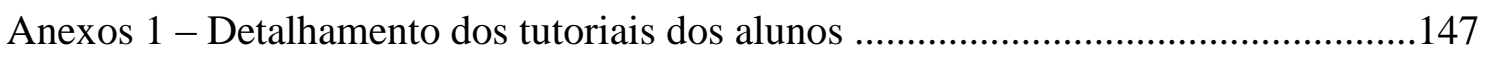

Anexos 2 - Diário de bordo da professora pesquisadora ...................................... 167 


\section{INTRODUÇÃO}

Esta pesquisa tem por objetivo estudar o desenvolvimento das capacidades de linguagem de alunos adolescentes em francês como língua estrangeira (doravante FLE) por meio da produção do gênero multimodal tutorial em vídeos. Sendo assim, procuramos verificar se os alunos desenvolvem as capacidades de linguagem através de uma sequência didática (SD) visando o ensino desse gênero. Nosso estudo contribui, portanto, para as pesquisas que têm sido realizadas pelo grupo ALTER-AGE-CNPq, do qual faz parte, e pretende investigar dois dos campos menos estudados pelo grupo: o papel dos gêneros multimodais no ensino-aprendizagem do francês e o ensinoaprendizagem do francês por adolescentes.

O trabalho com gêneros textuais como instrumento para o desenvolvimento de capacidades de linguagem de alunos em FLE não é novo nos estudos do grupo ALTERAGE, como podemos constatar em pesquisas de Barioni (2010), Guimarães-Santos (2012), Rocha (2014), Melão (2014), Oliveira (2014), Santos (2016), todavia, o nosso estudo difere dos realizados, uma vez que tínhamos por objetivo analisar também as gravações das conversas trocadas pelos alunos e o diário de bordo da professorapesquisadora como forma de trazer mais indícios sobre o desenvolvimento dessas capacidades e sobre o processo de produção textual dos alunos. Mais do que isso, nossa pesquisa é inovadora ao propor o uso de um gênero multimodal, o que já tinha sido tratado por Melão (2014) ao estudar o gênero anúncio publicitário, no entanto, no nosso caso, como dissemos, nos voltamos para imagens móveis, como as dos vídeos, e para um gênero que é frequentemente utilizado nas práticas sociais do nosso público-alvo, os adolescentes.

Ainda que a perspectiva do ensino-aprendizagem de línguas (materna e estrangeira) por meio de gêneros não seja nova no Brasil, nos deparamos com materiais didáticos que privilegiam aspectos exclusivamente linguísticos do texto, fazendo com que esse ensino seja desprovido de uma relação com a situação autêntica de comunicação (SCHNEUWLY; DOLZ, 2013). Esquece-se assim, a natureza dos gêneros enquanto construções históricas e sociais correlacionados por uma visão ideológica e também histórica e social do sujeito. Dessa forma, é produzida, como salientam Dolz e Schneuwly, "uma inversão em que a comunicação desaparece quase totalmente em prol 
da objetivação, e o gênero torna-se uma pura forma linguística, cujo domínio é o objetivo" (2013, p.61, grifo dos autores).

Ademais, como veremos ao longo deste estudo, em uma perspectiva vigotskiana do desenvolvimento, concebemos o gênero textual como um instrumento psicológico e o ensino com base em gêneros um instrumento para o desenvolvimento das capacidades de linguagem (DOLZ, PASQUIER, BRONCKART, 1993) dos alunos, a saber: as capacidades de ação, as discursivas e as linguístico-discursivas, que definiremos mais à frente.

Sendo assim, acreditamos que o ensino de línguas com base em gêneros de textos trará bons resultados, pois como ressalta Cristovão, (2010, p.105), "quanto maior for o conhecimento de gêneros diversos, mais possibilidades terá o agente de agir adequadamente com a linguagem em diversas situações”. Isto é, com o contato com textos de variadas esferas sociais e na compreensão da utilização dos textos pertencentes a determinado gênero, os alunos poderão adaptar os conhecimentos a outros gêneros, ainda que desconhecidos. Dentre as esferas sociais, não podemos ignorar o ambiente digital, pois com o avanço da tecnologia, os suportes digitais assumiram grande importância no nosso agir e, consequentemente, nas nossas trocas sociais, fazendo com que os estudos de gêneros emergentes na era digital ${ }^{1}$ e suas contribuições no ensino de línguas sejam necessários. Tal como salientado por Marcuschi, a análise desses textos faz-se necessária por três aspectos:

“(1) seu franco desenvolvimento e um uso cada vez mais generalizado; (2) suas peculiaridades formais e funcionais, não obstante terem eles contrapartes em gêneros prévios; (3) a possibilidade que oferecem de rever conceitos tradicionais, permitindo repensar nossa relação com a oralidade e a escrita" (2005, p. 14).

Considerando-se que o autor fez essa afirmação no ano de 2005, e partindo da concepção de que a linguagem se molda e se modifica de acordo com os contextos sócio-históricos de uso, percebemos que, além de termos constantemente que rever conceitos tradicionais sobre a oralidade e a escrita, passamos a ter outras preocupações, pois hoje, os avanços tecnológicos e sua consequente velocidade de transmissão de dados eletronicamente, nos permite não só o envio de mensagens de voz como de imagens e vídeos. Há, pois, uma relação de quase paridade entre os elementos

\footnotetext{
${ }^{1}$ Utilizamos os termos "gêneros digitais", "gêneros emergentes na era digital", inspirados na obra "Hipertexto e gêneros digitais - Novas formas de construção de sentido" de Marcuschi e Xavier (2005). Eles se referem a todos os gêneros textuais que estão surgindo no contexto tecnológico atual.
} 
multimodais ${ }^{2}$ nos novos gêneros que vão surgindo e esses novos gêneros implicam em novas formas de agir por meio da linguagem criando uma necessidade de estudos na área.

Assim, ainda que o trabalho com gêneros multimodais tenham ganhado expressividade nos estudos brasileiros, como constatamos, por exemplo, no Simpósio Internacional de Estudos de Gêneros Textuais (SIGET) ocorrido no ano de 2015³ o trabalho com a produção de vídeos em sala de aula ainda é pouco explorado, o que nos fez refletir sobre o ineditismo da nossa pesquisa.

O vídeo tutorial, com efeito, parece ter surgido como uma adaptação do manual de instruções e ganhou força com a utilização da internet e de suas redes de compartilhamento de informações. Nele, o interlocutor, que pode ser um personagem fictício, um especialista, uma pessoa pública ou uma pessoa desconhecida, grava um passo à passo de como se fazer algo articulando variados recursos: texto oral, escrito, imagens, efeitos, músicas etc. Para escolher o gênero a ser trabalhado em sala de aula com os alunos adolescentes, consideramos quatro dimensões postuladas por Dolz e Schneuwly (2013): a psicológica, a cognitiva, a social e a didática. A dimensão psicológica é relacionada às motivações e aos interesses dos alunos; a cognitiva é a dimensão que leva em consideração a complexidade do tema e o conhecimento global dos alunos; a social seria a densidade social do tema escolhido, sua relação com o aluno fora ou dentro da escola e o seu potencial na elaboração de uma atividade em sala de aula; por fim, a didática é a concepção de que o gênero escolhido deve ser apreensível, mas sem ser excessivamente cotidiano. Diante disso, selecionamos o tutorial em vídeos, pois levamos em consideração que o gênero em questão pode motivá-los por ser um gênero emergente e que traz um suporte diferente do qual os alunos estão habituados em sala de aula. De fato, como observamos em diferentes contextos, o tutorial em vídeos é um gênero que tem adquirido grande relevância, sobretudo entre jovens; por ser um gênero multimodal, ou seja, com o tutorial, os alunos trabalharão algumas estratégias

\footnotetext{
${ }^{2} \mathrm{O}$ termo multimodalidade tem sido muito recorrente nas pesquisas atuais, uma vez que o avanço da tecnologia e a ampla utilização da internet permitiu a produção de textos com múltiplas semioses, desde tamanhos e cores nas letras até imagens e vídeos na sua estruturação. Assim, em nosso estudo, concordamos com Dionísio (2005) que utiliza o termo para designar as diferentes maneiras e modos de representação na construção de uma dada mensagem.

${ }^{3}$ Ao fazermos uma busca da palavra multimodalidade no caderno de resumos do SIGET 2014, chegamos ao número 76 de ocorrências e a busca da palavra multimodal resultou em 100, sendo que o evento contou com 682 trabalhos apresentados. Evidentemente, esta busca foi aproximativa, uma vez que as palavras acima podem ter aparecido mais de uma vez nos resumos. Disponível em: http://siget2015.fflch.usp.br/sites/siget2015.fflch.usp.br/files/u56/Caderno\%20de\%20resumos\%204.pdf. Acesso em 09 jan. 2015.
} 
básicas para a construção de sentido do texto, como por exemplo, os recursos imagéticos associados aos recursos verbais; por razão do gênero poder proporcionar discussões em relação a seu uso, dentro ou fora da escola; por ser um gênero apreensível, por ser próximo dos alunos, e ao mesmo tempo complexo, por combinar linguagem verbal e visual. Embora os autores postulem que o gênero não pode ser excessivamente do cotidiano - dimensão didática -, é importante salientar que eles estavam situados no contexto de Língua Materna (LM) e sabemos que, no contexto de Língua Estrangeira (LE), como no nosso caso, os gêneros do cotidiano são os primeiros a serem ensinados em sala de aula.

Além disso, levamos em consideração que o público com o qual trabalhamos são frequentes produtores e consumidores desse gênero (ARAÚJO, 2005). Assim, partimos do pressuposto que, a partir da compreensão e produção de gêneros aos quais os alunos estejam habituados em Língua Materna, ou seja, na apropriação de textos mais conhecidos, os alunos poderão passar a produzir esses mesmos textos em francês com mais facilidade. Outra razão que nos levou à escolha desse gênero é o fato de ele ser multimodal, fazendo com que os alunos percebam a importância dos recursos imagéticos na construção de sentido do texto, pois como ressalta Araújo (2005)

“o bom produtor hoje, sobretudo se ele navega na web, não precisa apenas ter uma ideia na cabeça, é necessário que ele domine estratégias básicas de textualização e, ainda, aspectos multimodais dessa atividade".

Para alcançar os objetivos aos quais nos propomos, nesta pesquisa nos embasamos no Interacionismo Sociodiscursivo através dos estudos de Bronckart (1999, 2003, 2006, 2008, 2010), no conceito de capacidade de linguagem, proposta por Dolz, Pasquier e Bronckart (1993). Em relação às sequências didáticas com base em gêneros textuais, nos baseamos nas pesquisas de Dolz (2004/2012), Schneuwly (2004/2012) e em seus desdobramentos no Brasil, como, por exemplo, Lousada (2010) e Cristovão (2010/2014/2015), entre outros.

Porém, justamente por trabalharmos com um texto multimodal e pelo fato de o ISD não possuir um modelo de análise textual que aborde a questão da multimodalidade, optamos por apoiar em outra vertente teórica, que permitisse a análise de textos multimodais. Para tanto, utilizamos o quadro da Semiótica Sociointeracional concebido 
por Leal (2011) em que a autora propõe a união do quadro de análise do ISD com as categorias propostas pela Gramática do Design Visual de Kress e Van Leeuwen (2006).

Além de trazer contribuições na área de didática de línguas, pretendemos também trazer contribuições aos estudos de gêneros emergentes na era digital e, consequentemente, aos estudos sobre a multimodalidade, pois, como já dissemos e como mostraremos no decorrer do nosso estudo, a multimodalidade passou a estar mais presente nas nossas práticas sociais.

\section{OBJETIVOS E PERGUNTAS DE PESQUISA}

Esta pesquisa tem por objetivo estudar o desenvolvimento das capacidades de linguagem de alunos adolescentes em francês como língua estrangeira (doravante FLE) por meio da produção do gênero multimodal tutorial em vídeos. Sendo assim, procuramos verificar se os alunos desenvolvem as capacidades de linguagem através de uma sequência didática (SD) visando o ensino desse gênero. Para realizá-la, procuraremos responder às seguintes perguntas de pesquisa:

i) Quais são as características do gênero tutorial em vídeo? Quais dessas características podem compor o modelo didático desse gênero para alunos adolescentes?

ii) Qual SD do gênero tutorial pode ser elaborada para alunos adolescentes?

iii) Houve desenvolvimento das capacidades de linguagem dos alunos ao compararmos as produções inicial e final?

iv) Quais indicações o diário de bordo da professora pesquisadora e as conversas gravadas entre alunos durante as aulas podem trazer sobre o processo de produção textual? 


\section{ORGANIZAÇÃO DA DISSERTAÇÃo}

\section{Capítulo I - Pressupostos teóricos}

Este capítulo tem por objetivo apresentar as linhas teóricas nas quais nos embasamos para a construção da nossa pesquisa. Dividido em dez seções, temos: primeiramente, o quadro teórico metodológico do Interacionismo Social, corrente que dá origem à nossa linha teórica, o Interacionismo Sociodiscursivo (ISD); na seção dois, traremos, assim, os princípios básicos do ISD; sendo um dos nossos objetivos abordar a concepção do gênero de textos como um instrumento para o desenvolvimento das capacidades de linguagem, apresentaremos na seção três, os conceitos de instrumento psicológico e de zona de desenvolvimento proximal; em seguida, na quarta seção abordaremos a concepção de gênero para o ISD; na quinta seção, apresentaremos o gênero objeto de nosso estudo, o tutorial em vídeos; posteriormente, na sexta seção, traremos algumas considerações sobre os gêneros textuais e a didática das línguas; com o intuito de trabalhar os gêneros textuais em sala de aula; discorreremos, na seção sete, sobre dois aspectos da engenharia da didática: o modelo didático e a sequência didática; veremos nas seções seguintes, dois quadros de análise nos quais nos embasamos para a construção do modelo didático e da sequência didática; o modelo de análise textual proposto pelo ISD e as funções da Gramática do Design Visual, nas seções oito e nove, respectivamente; para finalizar o capítulo, na seção dez, apresentaremos o quadro da união dos dois modelos de análise citados anteriormente: o quadro da Semiótica Sociointeracional.

\section{Capítulo II - Procedimentos metodológicos}

Dividido em nove seções, este capítulo foi organizado da seguinte forma: na seção um, apresentaremos o contexto no qual a pesquisa foi realizada, bem como seus participantes; em seguida, na seção dois, discorreremos sobre as etapas da nossa pesquisa; na terceira seção, traremos os procedimento para elaboração do modelo didático do gênero tutorial em vídeo; posteriormente, na seção quatro, apresentaremos o modelo didático do gênero tutorial em vídeo para assim, na seção cinco, teremos a sequência didática do gênero; nas seções seguintes, seis e sete, respectivamente, abordaremos sobre a sequência didática do gênero e os instrumentos de coleta de dados gerados na sua aplicação; na oitava seção, relataremos os procedimentos de seleção de dados e, por fim, na nona seção, os procedimentos de análise de dados. 


\section{Capítulo I - Resultado das análises}

Dividido em três partes, neste capítulo, apresentaremos as análises das produções dos tutoriais em vídeos dos alunos. Assim, na primeira seção, temos as análises da turma A e, posteriormente, na seção dois, a da turma B. A última seção será dedicada à discussão das análises e resultados.

\section{Capítulo IV - Considerações finais}

Para finalizar o nosso estudo, dedicaremos o quarto capítulo para as nossas considerações finais. 


\section{CAPÍTULO I - FUNDAMENTAÇÃO TEÓRICA}

Este capítulo tem por objetivo apresentar as linhas teóricas nas quais nos embasamos para a construção da nossa pesquisa. Dividido em dez seções, temos: primeiramente, o quadro teórico metodológico do Interacionismo Social, corrente que dá origem à nossa linha teórica, o Interacionismo Sociodiscursivo (ISD); na seção dois, traremos, assim, os princípios básicos do ISD; sendo um dos nossos objetivos abordar a concepção do gênero de textos como um instrumento para o desenvolvimento das capacidades de linguagem, apresentaremos na seção três, os conceitos de instrumento psicológico e de zona de desenvolvimento proximal; em seguida, na quarta seção traremos a concepção de gênero para o ISD; na quinta seção, o gênero objeto de nosso estudo, o tutorial em vídeos; posteriormente, na sexta seção, temos algumas considerações sobre os gêneros textuais e a didática das línguas; com o intuito de trabalhar os gêneros textuais em sala de aula; reservamos a seção sete para apresentar dois aspectos da engenharia da didática: o modelo didático e a sequência didática; temos nas seções seguintes, dois quadros de análise nos quais nos baseamos para a construção do modelo didático e da sequência didática: o modelo de análise textual proposto pelo ISD e as funções da Gramática do Design Visual, seções oito e nove, respectivamente; para finalizar o capítulo, na seção dez, apresentaremos o quadro da união dos dois modelos de análise citados anteriormente: o quadro da Semiótica Sociointeracional.

\section{O Interacionismo Social}

O Interacionismo Social (IS) provém de uma orientação epistemológica que abrange variadas correntes da filosofia e das ciências humanas, tais como as obras de Bühler (1927), Claparède (1905), Dewey (1910), Durkheim (1922), Mead (1934), Wallon, e Vigotski. Segundo Jean-Paul Bronckart (2007), embora essas correntes tenham variações de cunho metodológico ou teórico, elas partilham a concepção de que o desenvolvimento do pensamento humano é resultado de uma socialização historicamente situada e de suas interações de caráter semiótico.

A concepção interacionista social refuta a ideia de que podemos interpretar as condutas humanas, seja somente pelo potencial genético ou somente pelo meio 
preexistente, posição tomada pelo cognitivismo e pelas neurociências, e pelo behaviorismo, respectivamente. Assim, como salienta o autor:

\begin{abstract}
"essa corrente sustentava que a problemática da construção do pensamento consciente humano deveria ser tratado paralelamente à construção do mundo dos fatos sociais e das obras culturais, e considerava que os processos de socialização e os processos de individuação (isto é, de formação das pessoas individuais) constituíam duas vertentes indissociáveis do mesmo desenvolvimento humano"
\end{abstract} (BRONCKART, 2006, p. 08)

Dando ênfase à historicidade da espécie humana, o interacionismo social se interessa: pelas condições em que se desenvolveram a espécie humana e as suas formas de interação de caráter semiótico; pela análise da estruturação e funcionalidade dessas interações sociais, bem como a análise dessas formas semióticas; e como as características da espécie, o desenvolvimento e a aprendizagem transformam a espécie humana em pessoas, "conscientes de sua identidade e capazes de colaborar com as outras na construção de uma racionalidade do universo que os envolve" (BRONCKART, 2007, p. 22).

Sustentada também pelas ideias de Hegel sobre os estudos do caráter dialético do desenvolvimento da atividade e do psiquismo humano (Phénomélogie de l'esprit, 1807), por Marx e Engels com a linguagem e o trabalho como instrumentos na construção da consciência (Thèses sur Fauerbach,1888; Le Capital, 1885; Grundrisse 1847; Dialectique de la nature, 1883), dentre muitos outros pensadores como Kant (1923/1972), Leroi-Gourhan (1964, 1965), Morin (1977), Habermas (1987) e Ricoeur (1986), é primordialmente em Vigotski que o Interacionismo Sociodiscursivo, corrente sobre a qual discorreremos na seção seguinte, se baseia como uma das fontes maiores.

\title{
2. O Interacionismo Sociodiscursivo
}

Apesar de o Interacionismo Sociodiscursivo (ISD) propor um modelo de análise de textos, esse quadro tem por objetivo principal trazer aportes teóricos sobre as práticas de linguagem no desenvolvimento de capacidades tanto da ordem dos saberes como da ordem do agir humano (BRONCKART, 2006). Tendo como uma das influências maiores 
Vigotski (1934/1997/1999) e sua psicologia do desenvolvimento, suas ideias rompem com as da filosofia clássica em que o objeto de estudo das ciências humanas baseava-se na relação entre o sujeito pensante e o mundo. Sendo assim, seus estudos tomaram uma nova direção: a ação coletiva ou a atividade humana na construção do ser. Assim, para o autor (BRONCKART, 2006), essa corrente concebe à linguagem um papel primordial para o desenvolvimento humano e social.

Para Bronckart (2006), o ISD tem alguns princípios básicos:

- Uma "corrente da ciência do humano"” (BRONCKART, 2006, p.09): nessa concepção, contesta-se a fragmentação das ciências humanas em correntes "linguísticas", "psicológicas", "sociológica” etc. Tem-se assim, uma ideia de uma corrente unificada em que, para se entender o desenvolvimento humano, considera-se as dimensões biológicas, sociais, culturais, cognitivas, sem abandonar a concepção de que essas dimensões estão em constante interação. Nessa corrente, o objeto de estudo são as questões concretas da vida, tais como os problemas em relação ao trabalho, à formação, à educação etc.

- Uma articulação entre os princípios do materialismo monista e paralelista: o princípio do materialismo monista provém das reflexões de Spinoza (1677/1954) que parte da reflexão de que "o universo é apenas a matéria em perpétua atividade, e que todos os objetos que ele inclui, compreendem nele os processos de pensamento atestáveis na espécie humana, são realidades propriamente materiais" (BRONCKART, 2006, p. 10). Partindo desse pressuposto, rejeita-se qualquer tipo de dualismo: apesar de termos "objetos" que aparentam ser físicos ou psíquicos, essa diferença entre os objetos se dá somente no plano fenomenal, pois em tese, "tudo é constituído da mesma matéria" (BRONCKART 2006), ou seja, não há diferença em sua essência. O princípio do paralelismo, diz respeito à concepção de que no curso da evolução, foram surgindo uma organização de "objetos", cada vez mais complexos e dinâmicos, devido a sua interação com o meio. Nos organismos vivos de uma modo geral, essa organização se dá por um psiquismo primário e no homem, o psiquismo primário está em constante interação com o pensamento consciente.

\footnotetext{
${ }^{4}$ Grifo do autor.
} 
- A perspectiva dialética e histórica do desenvolvimento humano: baseado em Marx e Engels (1846/1968), essa perspectiva vai contra a concepção essencialista do humano, retomando a posição de que o psiquismo humano é construído historicamente. Por questões de sobrevivência, o ser humano teve a necessidade de trabalhar coletivamente, resultando assim, na elaboração de instrumentos: "instrumentos a serviço de sua realização concreta" e produções linguageiras a serviço da gestão de conjunto (BRONCKART, 2006, p.11). Isso implicou (e implica) em mundos sociais, econômicos, culturais e semióticos que internalizados pelos sujeito foi transformando o pensamento consciente do humano no estado em que se encontra.

- A dupla ancoragem da língua: defendida por Saussure, essa tese afirma que o psiquismo é construído, de um lado, pelo o social e pela cultura e de outro, pelo organismo humano singular (BRONCKART, 2006, p. 11)

É importante ressaltar que o ISD foi consolidado através de uma preocupação que surgiu em sala de aula, mais particularmente em Genebra, quando Bronckart ministrou um curso de linguística para professores e formadores. Nesse projeto, Bronckart contou com diversos colaboradores, dentre eles, Schneuwly e Bain (BRONCKART, 2006) e seu principal objetivo tornou-se propor uma adaptação de pesquisas e modelos teóricos para a sala de aula, ou seja, conciliar a filosofia e a prática. Assim, quando Bronckart (2005) diz que seus estudos são voltados à ciência do humano, ele traz uma abordagem em que se preocupa em realizar uma consistente reflexão epistemológica dos dados construídos (filosofia) para se compreender e trazer soluções para os problemas da vida humana (prática). Ainda segundo o autor (2005), para legitimá-la, ela deve ser uma ciência da intervenção, ou seja, fazer da análise um meio de transformação dos problemas da atividade humana. Para ser uma ciência da intervenção, portanto, faz-se necessário entender a relação entre aprendizagem e desenvolvimento, pois só assim chegaremos na apropriação do objeto de estudo. Diante disso, pareceu-nos pertinente adotarmos essa perspectiva teórica para o desenvolvimento de nossa pesquisa.

Na seção seguinte, discorreremos sobre dois aspectos fundamentais na concepção de aprendizagem e desenvolvimento: o conceito de instrumento e o de zona de desenvolvimento proximal (ZPD), além da noção de mediação. 


\section{O instrumento psicológico e a Zona de Desenvolvimento Proximal}

Como vimos anteriormente, Vigotski (2003), em sua perspectiva do Interacionismo Social, defende o desenvolvimento humano como um resultado da constante interação existente entre o meio ou as condições sociais e o ser humano, sendo a nossa relação com o mundo mediada por instrumentos. Na nossa pesquisa, consideramos a sequência didática por meio de gêneros textuais um instrumento psicológico que mediatiza o agir dos aprendizes e os objetos de ensino (Schneuwly e Dolz, 2013) e para entender a nossa posição, faz-se necessário, primeiramente, compreender o conceito de instrumento psicológico e de zona de desenvolvimento proximal, conceitos sobre os quais discorreremos a seguir.

Para Vigotski (2003), todas as funções psíquicas superiores, como, por exemplo, a memória lógica, são considerados fenômenos psíquicos mediatizados uma vez que surgem com o auxílio de instrumentos psicológicos. Nesse sentido, em comparação à psicologia reflexiológica e behaviorista, no conceito de mediação postulado por Vigotski (2003) há uma modificação da unidade de análise dos fenômenos psíquicos. Na concepção behaviorista, utilizava-se o método associativo e direto, em que os processos psíquicos são apresentados por dois elementos em sua constituição: o estímulo e a reação (Friedrich, 2012, p. 54):

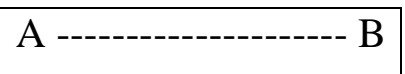

No esquema acima, $A$ seria o estímulo dado ao sujeito, como por exemplo, a tarefa de memorizar alguma informação e $B$, a reação, ou no caso, a memorização dessa informação. Vigotski (2003 apud Friedrich, 2012), postula que o método direto é característico da memória natural. Mas há um outro tipo de memória, a memória artificial ou como salientado por Schneuwly (2013) uma atividade tripolar: 


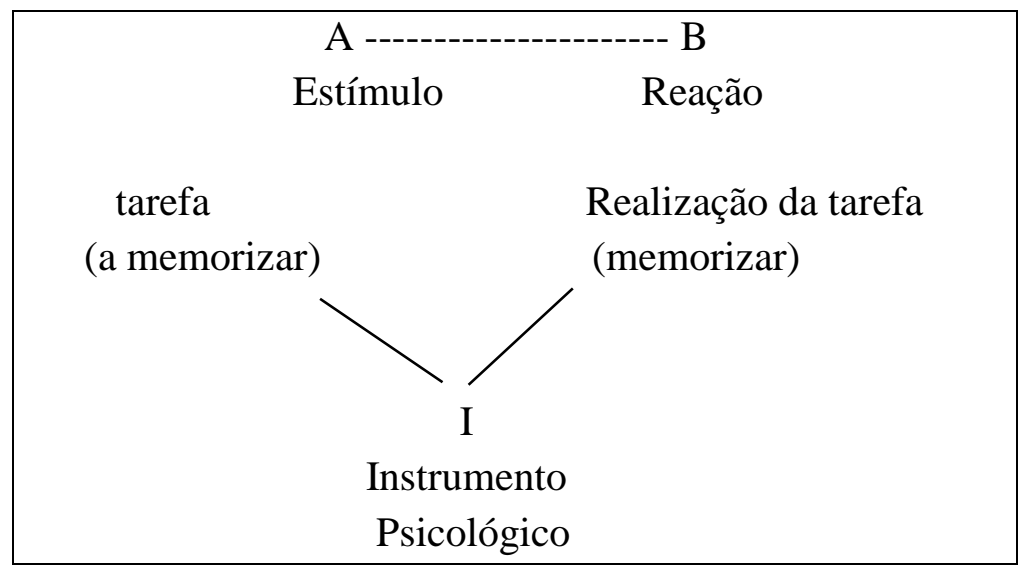

Nesse esquema criado por Friedrich (2012, p. 55), faz-se uma comparação entre a memória natural e a artificial. A memória artificial, que é classificada como uma das funções psíquicas superiores, acontece através da mediação por um instrumento psicológico. Levando em consideração que o nosso agir é sempre uma relação mediada, seja através de instrumentos concretos ou instrumentos psicológicos, Vigotski faz uma importante comparação entre esses dois tipos de instrumentos: o instrumento psicológico não está no meio, mas sim nas atividades psíquicas do sujeito, e diferentemente do instrumento concreto que modifica o meio, o instrumento psicológico é uma forma de influência sobre aquele que age, modificando-o ou como bem explica Schneuwly sobre a tripolaridade da atividade:

\footnotetext{
"a ação é mediada por objetos específicos, socialmente elaborados, frutos das experiências das gerações precedentes, através dos quais se transmitem e se alargam as experiências possíveis. Os instrumentos encontram-se entre o indivíduo que age e o objeto sobre o qual ou a situação na qual ele age: eles determinam seu comportamento, guiam-so, afinam e diferenciam sua percepção da situação na qual ele é levado a agir" (2010, p. 21).
}

Diante do que expusemos, podemos identificar o instrumento psicológico através de três critérios: “1) é uma adaptação artificial; 2) tem uma natureza não orgânica, ou, em outras palavras, tem uma natureza social e 3) é destinado ao controle dos próprios comportamentos psíquicos e dos outros" (Friedrich, 2012, p.58). Assim, por exemplo, as obras de arte, os diagramas, os meios minimotécnicos são instrumentos psicológicos. Nessa lista, poderíamos acrescentar também, os gêneros textuais. 
Com uma preocupação voltada à educação, Vigotski (2003) postula que a escola tem por objetivo dispor de instrumentos psicológicos para que os alunos se apropriem dos objetos de ensino. Nesse sentido, é importante ressaltar sua concepção de aprendizagem e desenvolvimento e, por conseguinte, a de zona de desenvolvimento proximal. Diferentemente de proposições em que a aprendizagem e o desenvolvimento são independentes ou da concepção de que elas são um único processo, em Vigotski (2003) há uma "interdependência entre esses dois processos" (Friedrich, 2012, p.109). Para a autora, a aprendizagem é anterior ao desenvolvimento, pois as funções psíquicas superiores são formadas pelos conhecimentos já adquiridos pelas crianças e a aprendizagem é de suma importância para seu desenvolvimento.

A Zona de Desenvolvimento Proximal (ZDP) opõe-se à concepção do desenvolvimento presente: enquanto o conceito de desenvolvimento presente compreende os conhecimentos que a criança já tem internalizado, a ZDP "antecipa os conhecimentos possíveis" (Friedrich, 2012, p. 110). No contexto escolar, por exemplo, ela engloba todas as tarefas que o aluno conseguirá fazer com o auxílio do professor. Sendo assim, a ZDP seria a distância em que o aluno consegue agir em autonomia e aquilo que ele realiza com ajuda, ou, nas palavras de Vigotski (2003), no espaço entre a Zona de desenvolvimento presente e Zona de Desenvolvimento Potencial. Assim, o desenvolvimento do aluno se dá através da apropriação de pré-construtos presentes em sala de aula, ou seja, o meio e o seu convívio social têm grande importância para que o desenvolvimento ocorra. Segundo o autor (Vigotski, 2003), se o meio não for desafiador o processo de desenvolvimento pode não ocorrer. Os pré-construtos, por sua vez, regulam a sua atividade social e, aos poucos, as regulações tornam-se autorregulações, o controle passa a ser voluntário. É, pois, nesse espaço entre o que o aluno já se apropriou e no que ele não realiza em autonomia que os instrumentos psicológicos atuam e, por esta razão, é muito importante que a intervenção didática ocorra através deles.

$\mathrm{Na}$ nossa pesquisa, assim, acreditamos que a sequência didática por meio do gênero tutorial em vídeos atuará nessa transição do desenvolvimento potencial para o desenvolvimento real dos alunos, propiciando o desenvolvimento de capacidades de linguagem, ou seja, que ela servirá como um instrumento psicológico que mediará a ação do aluno e que, aos poucos, essas regulações se tornarão autorregulações. Com o intuito de mostrar como os gêneros textuais podem se tornar objeto de ensino, nas próximas seções nos dedicaremos à concepção de gêneros textuais na perspectiva interacionista 
social, discorreremos sobre o gênero tutorial em vídeos e, em seguida, discutiremos os gêneros como instrumentos no aprendizado de línguas.

\section{Os gêneros textuais}

Tal como salientado anteriormente, o ISD confere um papel fundamental à linguagem para o desenvolvimento humano. Para explicitar a função da linguagem, Bronckart (2006) serve-se do termo agir. Para ele, todas as espécies agem socialmente e comunicativamente, mas, a espécie humana se difere das outras, uma vez que é capaz de produzir um agir comunicativo verbal por meio de instrumentos semióticos organizados em textos. Além disso, esse agir é resultado de uma formação social desenvolvida no curso da história, portanto, as ações de linguagem estão estritamente ligadas aos tipos de atividades as quais elas estão relacionadas, isto é, a ação de linguagem tem como correspondente as representações que o produtor tem sobre o seu contexto de ação. Dito de outra forma, para agir por meio da linguagem, o agente escolhe e adapta, dentre o conjunto de gêneros que ele tem disponível, o que ele julga mais adequado para a situação de comunicação.

Para se entender a noção de gênero na perspectiva interacionista, Bronckart retoma a noção de gêneros discursivos proposta por Bakhtin (1953) e Volóshinov $(1977)^{5}$ segundo a qual cada atividade de linguagem é materializada por tipos relativamente estáveis de enunciados, os gêneros discursivos. Enquanto os gêneros são relativamente estáveis, os textos são mais maleáveis, sendo difícil a sua classificação. Além disso, os gêneros podem ser divididos em primários e secundários: os primários são os gêneros relacionados às situações de comunicação cotidianas, como por exemplo, uma conversa entre um vendedor e um cliente e os gêneros secundários são relacionados a situações mais complexas, como por exemplo, o gênero artigo científico, sendo que os gêneros primários dão origem aos gêneros secundários.

\footnotetext{
${ }^{5}$ Atualmente a influência dos conceitos de Bakhtin no ISD podem ser discutidas, uma vez que o autor fundador da nossa vertente teórica reviu seus estudos em uma longa pesquisa nos arquivos originais de Bakthin, que deu origem à a obra intitulada Bakhtin desmascarado: história de um mentiroso, de uma fraude, de um delírio coletivo (BRONCKART; BOTA, 2012). Assim, Bronckart reconhece que, de fato, os pressupostos teóricos nos quais se baseou para propor os fundamentos do ISD estão, na verdade, na perspectiva do teórico Volóshinov (1977). No entanto, guardamos as referências de Bakhtin (1953) para manter a coerência dos conceitos, pois nos baseamos em várias obras de Bronckart anteriores à obra citada.
} 
Partindo da concepção de que os gêneros são construções históricas e sociais, muitos gêneros são, ainda que em partes, dominados pelos locutores de uma língua, pois se não, a comunicação não aconteceria. Assim, segundo Lousada (2010), em língua estrangeira (daqui por diante LE) é necessário que os alunos tenham contato com gêneros mais ou menos dominados em língua materna (LM), uma vez que, na sociedade contemporânea do mundo ocidental os gêneros apresentam características similares, facilitando o aprendizado em LE. Nos níveis mais avançados, pode-se trabalhar gêneros mais complexos, dominados ou não em língua materna.

Bakhtin (1992) atribui grande importância ao estudo da natureza do enunciado enquanto construções históricas e sociais, na correlação de gêneros primários e secundários constituídos por uma visão ideológica, histórica e social do sujeito. Tal como salienta Cristovão, desconsiderar essa natureza

“é o mesmo que abstrair a língua de seu contexto de produção e, portanto, desviar-se da ótica proposta pelo Sociointeracionismo, que considera a língua como o instrumento de mediação usado pelo ser humano para agir com a linguagem" (2015, p. 31)

É importante salientar que esses gêneros não são considerados estáticos, uma vez que vão se adaptando às situações comunicativas e, segundo Cristovão, deve-se considerar essa plasticidade, pois "ao realizar uma ação de linguagem, o agente confronta suas próprias representações da situação vivida com as representações já cristalizadas por formações sociais outras" (2015, p. 37). Diante disso, os gêneros textuais continuam sendo entidades vagas, "as múltiplas classificações existentes são divergentes e parciais e nenhuma delas pode ser considerada como um modelo de referência estabilizado e coerente" (BRONCKART, 2010, p. 73).

Essa fluidez se dá, segundo o Bronckart (2010), devido à diversidade de critérios utilizados para se legitimar os gêneros, tais como o efeito comunicativo, o suporte utilizado, o conteúdo temático, o tamanho etc. Em suma, a organização dos gêneros mostra-se como uma nebulosa com pequenas ilhas relativamente estabilizadas e por conjunto de textos com contornos mais imprecisos, ou seja, gêneros claramente definidos e gêneros em que as definições ainda são vagas e divergentes. O tutorial em vídeos é um exemplo de gênero com intersecções parciais, uma vez que seus critérios de classificação ainda são móveis, por se tratar de um gênero bastante recente. Com o 
intuito de mostrar essa dinamicidade, na próxima seção, nos dedicaremos ao gênero objeto de estudo de nossa pesquisa.

\section{O Gênero tutorial em vídeos}

Como discutido anteriormente, há uma grande dificuldade de classificação de um gênero textual, uma vez que os critérios para a sua definição são diversos, fazendo com que alguns gêneros desapareçam no curso da história, ou se modifiquem de acordo com as práticas sociais dando origem a novos gêneros (BRONCKART, 2012). Nesse sentido, entendemos que os gêneros digitais surgem, pois são influenciados diretamente pelos avanços tecnológicos. O tutorial, a nosso ver, nos mostra essa dinamicidade, uma vez que parece ter surgido como uma adaptação do gênero manual de instruções (DA COSTA; SANTOS, 2009), anteriormente impresso, e foi se modificando de acordo com o contexto tecnológico vigente. No que concerne à sua definição, segundo Santiago et al. (2014) entende-se o tutorial como

\footnotetext{
"um texto especializado, repleto de termos, cujo objetivo é instruir um indivíduo ou um conjunto de indivíduos que necessitam de determinadas orientações para operacionalizar uma ferramenta informatizada, como uma rede social" (2014, p. $01)$.
}

Com o avanço da tecnologia e a consequente massificação do uso das redes de compartilhamento de informações (redes sociais), observamos que o gênero tutorial, antes restrito a fins computacionais, se generalizou a outros tipos de atividades, tais como, trabalhos manuais, cozinha, fotos etc. No entanto, percebemos que a situação de comunicação permaneceu "bipolar" (DOLZ et al, 2013, p. 183), pois reúne um usuário da internet que gostaria de ensinar algo a outros usuários da internet.

Assim como Dolz et al (2013) postulam que no gênero exposição há uma "assimetria de seus respectivos conhecimentos sobre o tema da exposição", entre o orador ou expositor e seu auditório, podemos dizer que, no gênero tutorial, há também essa assimetria entre o produtor do tutorial e o destinatário. No entanto, o que antes era 
produzido por um "especialista", nos primeiros tutoriais, hoje, com os tutoriais em vídeo, passou a ser produzido por outras pessoas, não necessariamente experts sobre o assunto ensinado. Acreditamos que, por ser um gênero produzido por pessoas não especialistas e por ser compartilhado em um ambiente mais livre, o texto, antes marcado pelo discurso formal proposto por especialistas, passou também a ter a sua versão informal. Essa informalidade dos gêneros que circulam nas redes sociais também resultou em uma outra característica que até então não estava presente nos tutoriais computacionais: o humor. Hoje, alguns tutoriais têm também um caráter de entretenimento, o que resultou em uma reestruturação, por exemplo, do plano global dos conteúdos temáticos.

Voltando novamente aos objetivos do gênero, percebemos que o ensinar algo a alguém ainda é seu foco principal, mas hoje, a nosso ver, poderíamos acrescentar o objetivo de ganhar visibilidade na internet e conquistar seguidores. Mais uma vez, retornamos às práticas sociais como critério para definição do gênero, pois acreditamos que a cultura da auto promoção, da imagem de si e da aceitação de si pelo outro tem sido muito presente no contexto vigente o que justificaria o novo objetivo por trás do gênero. Além disso, com o formato interativo proporcionado pela internet, percebemos que o gênero acabou ganhando essa interação e o interlocutor, que até então não tinha voz, passou a ter um espaço para reagir na recepção do texto, como discutiremos mais à frente no nosso modelo didático.

O avanço da tecnologia proporcionou outros suportes para o gênero, que até então tinha suas versões em papel com texto escrito e/ou imagens (manual de instrução) e passou a ter sua versão digital com textos escrito e/ou imagens ou em vídeos (tutorial voltado à área computacional ou voltados à temas variados). Quanto à relação entre o texto verbal e o não verbal, poderíamos dizer, em uma análise mais superficial, que do tutorial com objetivos computacionais para o tutorial com temas variados, não tivemos grandes modificações.

Para discorrer sobre esse assunto, primeiramente, traremos os princípios da relação entre o verbal e não verbal postulados por Nöth e Santella (1998).

Segundo os autores (1998, p.54-55) a relação entre o verbal e o não verbal pode ser classificada em três princípios:

a) o princípio da redundância em que a imagem é inferior ao texto e o complementa;

b) o princípio da complementariedade em que a imagem e o texto verbal têm uma importância equivalente; 
c) o princípio da informatividade em que a imagem tem um valor superior ao texto.

Nas três fases destacadas do tutorial, poderíamos dizer que encontramos tanto a imagem com grau de redundância, complementariedade e informatividade, no entanto, o tutorial em vídeos se difere dos outros por possibilitar a articulação dos três tipos de imagem em um mesmo texto. Em outras palavras, se pegarmos, por exemplo, um manual de instruções, observaremos uma padronização das imagens ao logo do texto: se há imagens com o princípio de redundância, ela aparecerá no decorrer do texto com o mesmo princípio; se há imagens complementares, ela aparecerá igualmente padronizada e assim por diante. Podemos dizer o mesmo do tutorial para fins computacionais. No tutorial em vídeos, por seu turno, podemos encontrar em um mesmo texto uma articulação de imagens com princípio de redundância, de complementariedade e de informatividade.

Acreditamos, também, que essas categorias podem ser aplicadas em outros aspectos multimodais do vídeo como nos efeitos de imagem, no som, na música etc.

Diante do que expusemos, o quadro abaixo faz um resumo da (re)organização do gênero tutorial: 


\section{Quadro 1: A (re)organização do gênero tutorial}

\begin{tabular}{|c|c|c|c|}
\hline & Manual de instruções & $\begin{array}{l}\text { Tutorial para fins } \\
\text { computacionais }\end{array}$ & $\begin{array}{lr}\text { Tutoriais } & \text { em vídeo } \\
\text { com } & \text { temáticas } \\
\text { variadas } & \end{array}$ \\
\hline $\begin{array}{l}\text { Situação } \\
\text { comunicação }\end{array}$ & $\begin{array}{lr}\text { - Bipolar }- & \text { entre um } \\
\text { especialista e } & \text { uma } \\
\text { pessoa que } & \text { precisa } \\
\text { aprender } & \text { a } \\
\text { montar/utilizar } & \text { alguma } \\
\text { coisa. } & \end{array}$ & $\begin{array}{l}\text { - Bipolar }- \text { entre } \text { um } \\
\text { especialista da área } \\
\text { computacional e uma } \\
\text { pessoa que gostaria de } \\
\text { aprender algo na área. }\end{array}$ & $\begin{array}{l}\text { - Bipolar - entre uma } \\
\text { pessoa } \\
\text { necessariamente } \\
\text { especialista e uma } \\
\text { pessoa que gostaria de } \\
\text { aprender a fazer algo ou } \\
\text { se entreter. }\end{array}$ \\
\hline $\begin{array}{l}\text { Local de produção, } \\
\text { circulação } \\
\text { suporte }\end{array}$ & $\begin{array}{l}\text { - Formato impresso e } \\
\text { estava restrito à alguém } \\
\text { que comprou um } \\
\text { produto. }\end{array}$ & $\begin{array}{l}\text { - Formato digital e a } \\
\text { internet como meio de } \\
\text { circulação. }\end{array}$ & $\begin{array}{l}\text { - Formato digital e a } \\
\text { internet como meio de } \\
\text { circulação. }\end{array}$ \\
\hline Obj & - Ensinar algo à alguém. & - Ens & $\begin{array}{l}\text { - Ensinar algo à alguém; } \\
\text { - Ganhar visibilidade e } \\
\text { conquistar seguidores na } \\
\text { internet; } \\
\text { - Entreter alguém. }\end{array}$ \\
\hline $\begin{array}{l}\text { Grau } \\
\text { formalidade }\end{array}$ & - Lin & - Linguagem formal. & $\begin{array}{l}\text { - Linguagem formal; } \\
\text { - Linguagem informal. }\end{array}$ \\
\hline Formato & $\begin{array}{l}\text { - Texto escrito; } \\
\text { - Texto escrito com } \\
\text { imagens; }\end{array}$ & $\begin{array}{l}\text { - Texto escrito; } \\
\text { - Texto escrito e com } \\
\text { imagens; } \\
\text { - Vídeos. }\end{array}$ & $\begin{array}{l}\text { - Texto escrito; } \\
\text { - Texto escrito e com } \\
\text { imagens; } \\
\text { - Vídeos. }\end{array}$ \\
\hline $\begin{array}{l}\text { Função da imagem } \\
\text { e de outros } \\
\text { recursos } \\
\text { multimodais }\end{array}$ & $\begin{array}{l}\text { - Imagem redundante; } \\
\text { - Imagem } \\
\text { complementar; } \\
\text { - Imagem informativa; } \\
\text { (Padronização de um } \\
\text { princípio ao longo do } \\
\text { texto) }\end{array}$ & $\begin{array}{l}\text { - Recursos multimodais } \\
\text { redundantes; } \\
\text { - Recursos multimodais } \\
\text { complementares; } \\
\text { - Recursos multimodais } \\
\text { informativos. } \\
\text { (Padronização de um } \\
\text { princípio ao longo do } \\
\text { texto) }\end{array}$ & $\begin{array}{l}\text { - Recursos multimodais } \\
\text { redundantes; } \\
\text { - Recursos multimodais } \\
\text { complementares; } \\
\text { - Recursos multimodais } \\
\text { informativos. } \\
\text { (Articulação dos três } \\
\text { princípios ao longo do } \\
\text { texto) }\end{array}$ \\
\hline
\end{tabular}

Nas seções precedentes, vimos que, na linha teórica que adotamos, o gênero textual pode ser visto como instrumento de mediação do nosso agir por meio da linguagem. Vimos, também, que os gêneros são construídos sócio historicamente, na correlação dos gêneros primários e secundários confrontados com a visão de mundo daquele que age e que contribuem para organizar as nossas atividades comunicativas.

Além disso, salientamos que os gêneros são dinâmicos, uma vez que são adaptados a nossa necessidade de comunicação. Para se mostrar como os gêneros vão se desenvolvendo no curso da história, trouxemos o gênero tutorial que foi se modificando de acordo com o avanço tecnológico e as necessidades comunicativas do contexto 
vigente. Assim, se é através dos gêneros de textos que suprimos nossas necessidade de comunicação, as aulas de línguas precisam ser voltadas à apropriação de diversos gêneros (dos mais simples aos mais complexos) dado que pretendemos que nossos alunos tenham uma boa capacidade de comunicação. Logo, na seção seguinte, traremos os gêneros textuais como objeto de ensino-aprendizagem.

\section{Gêneros textuais e a didática de línguas}

Tal como salientado anteriormente, para o ISD a linguagem tem um papel fundamental no que se refere ao desenvolvimento humano e esta, por sua vez, é materializada a partir de textos. Tendo a preocupação do agir por meio da linguagem e, consequentemente, do desenvolvimento humano, muitos trabalhos são desenvolvidos sob essa perspectiva, tanto na didática de língua materna (SCHNEUWLY, DOLZ, 2012; BEZERRA, 2010; ABREU-TARDELLI, 2010; dentre outros), na didática de línguas estrangeiras (LOUSADA, 2008, 2010, 2012; CRISTOVÃO, 2009, 2002/2010, 2015, LEAL, 2011, dentre outros) e, ainda, no que diz respeito à multimodalidade na didática de línguas (LEAL, 2011; MELÃO, 2014; PEREIRA, 2015; FERREIRA; MELO, 2016).

Nesses estudos, os gêneros tem papel primordial no agir em diferentes esferas da atividade humana, sendo assim, o seu domínio contribui na participação do sujeito e no meio em que ele está inserido. Como salienta Rocha, por essa razão, "ter os gêneros textuais como instrumento de ensino e aprendizagem em sala de aula poderá contribuir para formar indivíduos conscientes e críticos das ações do outro, bem como de sua apropriação" (2014, p. 78).

Além disso, fazendo uma ligação com a perspectiva vigotskiana do desenvolvimento, para Schneuwly e Dolz (2013), os gêneros podem ser considerados como instrumentos uma vez que eles se encontram entre aquele que age e a situação na qual ele age, guiando-o e regulando o seu comportamento na situação na qual ele age. Ao transformar o instrumento, há uma modificação de comportamento do sujeito na situação. Nesse sentido, para esses autores, além do instrumento (o gênero textual) mediar uma atividade, ele também materializa-a, fazendo com que se torne um lugar privilegiado de transformação de comportamentos. 
Ademais, esses autores postulam que, para o ensino de línguas ser eficaz, os alunos precisam ter contato com gêneros das mais variadas esferas sociais, dentre eles, podemos destacar os gêneros digitais. Tal como salienta Leal (2011), com o advento da internet, a imagem passou a ter grande relevância, uma vez que as novas tecnologias permitiram a incorporação do visual na atividade comunicativa. Segundo a autora, não se pode abstrair os gêneros emergentes na era digital, já que é possível constatar "uma relação de paridade entre o verbal e o não verbal" (2011, p. 167). Marcuschi (2008) salienta, ainda, que o impacto das novas tecnologias está apenas se fazendo sentir, entretanto já se mostrou ter força o bastante tanto para construir como para devastar. Logo, há uma necessidade de estudos sobre esses novos gêneros que circulam na web e suas implicações no ensino de línguas, dado que somos diariamente cercados por eles.

Nesse sentido, considerando a diversidade de gêneros textuais com a qual nos deparamos, uma vez que eles são guiados pelo nosso meio e nossas necessidades de comunicação, colocamos em evidência a importância de ensiná-los formalmente. Acreditamos que, por meio deles, possibilitaremos o desenvolvimento de capacidades de linguagem (DOLZ, PASQUIER, BRONCKART, 1993) dos alunos tornando-os capazes de utilizá-las e adequá-las às mais variadas situações de comunicação em que eles são confrontados.

Como salientam Dolz, Pasquier e Bronckart (1993), fazemos uso das capacidades de interagir nos diversos meios sociais. Para eles, elas são definidas como necessárias para o aprendiz produzir um gênero em uma situação de comunicação determinada.

Organizada de forma hierárquica, a capacidade de ação é responsável pelas representações em relação ao contexto de produção. Essa capacidade auxiliará o aluno a refletir sobre os participantes, sejam os produtores ou os receptores do texto, bem como os objetivos e os conteúdos presentes no texto. As capacidades discursivas referem-se à organização textual: a organização dos temas, dos tipos de discurso e a organização sequencial mobilizados pelo produtor do texto. Por fim, as capacidades linguísticodiscursivas são responsáveis pela mobilização dos conteúdos linguísticos do texto. Elas são responsáveis por assegurar a coesão nominal e verbal, a conexão, assim como as modalizações e as vozes. Convém salientar, segundo os autores, que ainda que elas estejam dispostas separadamente, essa divisão visa apenas uma melhor compreensão, pois como sabemos, todos os mecanismos presentes em um texto estão interligados. 
Na tabela que segue, desenvolvida por Machado (2001 apud LOUSADA, 2010, p. 84), temos uma síntese do que pode ser objeto de ensino para se trabalhar as três capacidades de linguagem:

Quadro 2: As capacidades de linguagens e as possíveis atividades a serem desenvolvidas em uma sequência didática

Capacidade de ação: representações sobre a situação e mobilização de conteúdos

Capacidade discursiva: atividades relacionadas com a organização geral do texto (tipos de discurso e de sequências)

Capacidade linguístico-discursiva: atividades relacionadas com aspectos linguísticos (vozes, modalizações, coesão, conexão

Com a finalidade de trabalhar os gêneros textuais em sala de aula e, assim, desenvolver as capacidades de linguagem dos alunos, na seção seguinte, traremos a concepção de dois dispositivos que têm a finalidade de orientar as intervenções em sala de aula: o Modelo Didático e a Sequência Didática.

\section{O Modelo Didático e a Sequência Didática}

Para o desenvolvimento das capacidades de linguagem, Schneuwly e Dolz (2013) propõem dois aspectos da engenharia da didática: o Modelo didático (MD) e a Sequência Didática (SD). O MD de gênero é uma noção proposta por De Pietro et al (1996/1997), que tem como intuito fazer um levantamento das "dimensões ensináveis" (SCHNEUWLY; DOLZ; HALLER, 2013, p. 151) de um texto pertencente a um determinado gênero. A partir da sua criação, conseguimos encontrar "o que pode ser objeto de ensino-aprendizagem dentro de uma situação específica de comunicação" (CRISTOVÃO, 2010, p. 106). Para criá-lo, precisamos levar em consideração alguns aspectos das características do gênero do texto levantadas pelos experts; as práticas 
sociais de referência; os conhecimentos existentes tanto no plano linguístico e discursivo, sobre o gênero, quanto no plano psicológico, das teorias didáticas e de aprendizagem; e, finalmente, o conhecimentos sobre as capacidades de linguagem dos aprendizes (SCHNEUWLY; DOLZ; HALLER, 2013). Esses aspectos são relacionados entre si para definirmos os objetivos de aprendizagem dos alunos.

Como já ressaltado, o modelo didático nos proporciona uma visão dos "objetos potenciais para o ensino" (SCHNEUWLY; DOLZ; HALLER, 2013, p. 152), mas, como postulam os autores, não podemos ensinar o modelo como ele é apresentado. Ele deve ser trabalhado através de atividades e exercícios que são detalhados nas SDs. Assim, os MDs dão origem às SDs.

A sequência didática (SD) é um conjunto de atividades pedagógicas, construídas sistematicamente para se trabalhar determinado gênero em sala de aula. Ela tem como finalidade auxiliar o aluno a ter maior domínio de um gênero de texto, fazendo com que ele possa "falar ou escrever de maneira mais adequada numa dada situação de comunicação". (SCHNEUWLY; DOLZ; HALLER, 2013, p.83). Assim, segundo os autores, as SDs servem para proporcionar aos alunos "práticas de linguagem novas ou dificilmente domináveis".

As sequências são compostas por apresentação da situação de comunicação, produção inicial, conjuntos de módulos e produção final, como veremos no esquema a seguir:

Figura 1: Esquema da sequência didática
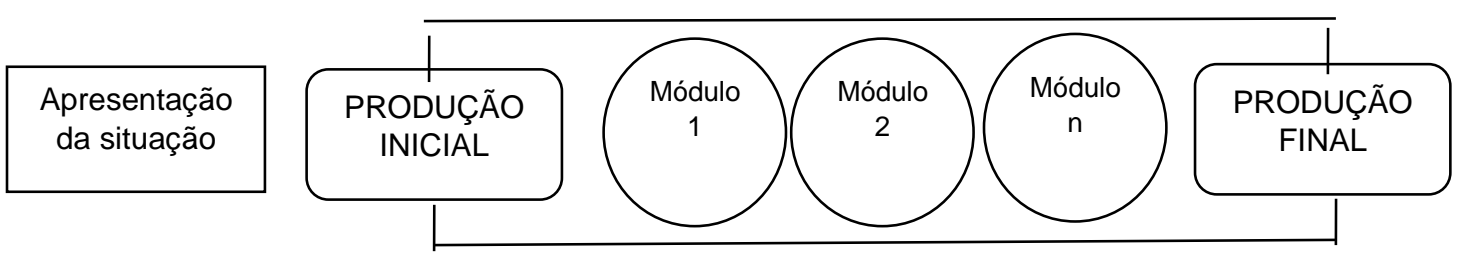

(DOLZ, et al., 2013, p. 81)

A apresentação da situação consiste na exposição detalhada da tarefa comunicativa que os alunos deverão realizar. Os alunos elaboram um primeiro texto do gênero a ser trabalhado: a primeira produção, ou produção inicial. 
Segundo os autores Dolz, Noverraz e Schneuwly (2013), essa primeira etapa nos permite fazer uma avaliação em relação às capacidades dos alunos e desenvolver atividades ajustadas às suas dificuldades. A primeira produção nos permite, assim, saber quais são as capacidades que os alunos deverão desenvolver ao longo da SD para se ter o domínio do gênero trabalhado. Se fizermos uma ligação com os estudos de Vigotski (2003), é nesse momento que compreendemos o desenvolvimento presente e o que ainda está na ZDP.

Os módulos são uma série de atividades e exercícios que auxiliarão os alunos a ter esse domínio. Como ressaltam Dolz, Noverraz e Schneuwly (2013, p. 87) "trata-se de trabalhar os problemas que apareceram na primeira produção e de dar aos alunos os instrumentos necessários para superá-los". Por fim, no momento da produção final, os alunos colocarão em prática os conhecimentos adquiridos. É através dela que conseguimos um diagnóstico sobre a sequência.

Para elaborar o MD e, em seguida, construir uma SD, os autores genebrinos baseiam-se em inúmeros estudos, dentre os quais os do ISD, propostos por Bronckart (1999, 2006, 2008) e sua equipe após um longo trabalho de observação e análise de textos pertencentes a variados gêneros. Com o modelo de análise textual do ISD, é possível construir uma descrição das características contextuais, discursivas e linguísticas do gênero textual em questão. Em nossa pesquisa, servimo-nos desse modelo de análise textual, apresentado na próxima seção, para construir o MD do gênero tutorial em vídeos. No entanto, como dissemos, o tutorial é construído na confluência de elementos verbais e visuais, portanto, no que se refere aos recursos multimodais na construção de sentido do texto, à semelhança do que propuseram Leal (2011) e Melão (2014), propomos uma junção do modelo de análise textual do ISD, voltado para textos verbais, com elementos analíticos propostos por Kress e Van Leeuwen (2006), voltados para textos multimodais.

Com o intuito de analisar as características contextuais, discursivas e linguísticodiscursivas do gênero tutorial em vídeo, a seguir, traremos o modelo de análise do Interacionismo Sociodiscursivo.

\section{O Modelo de análise do Interacionismo Sociodiscursivo}

Segundo Bronckart (2007), a produção textual pode ser influenciada pela situação de ação da linguagem e essa situação é constituída por três mundos formais: o 
físico, o social e o subjetivo. Os mundos formais "são conjuntos de representações sociais que podem ser objeto de uma descrição a priori ${ }^{6}$. Entretanto, em uma determinada situação de produção, o agente dispõe apenas de versões particulares dessas representações sociais" (BRONCKART, 2007, p.91). Assim, é de grande importância levar em consideração a situação de ação de linguagem externa, ou em outras palavras, as características dos mundos formais observáveis por uma determinada comunidade social e situação de ação de linguagem interna, as representações desse mesmo mundo interiorizadas pelo agente produtor. Bronckart (2007) salienta que, para produzir um texto, o agente precisa mobilizar as representações dos mundos formais interiorizadas por ele e essa mobilização é organizada em contexto de produção e conteúdos temáticos que descreveremos a seguir.

\subsection{O contexto de produção}

O contexto de produção, segundo Bronckart (2007), é o conjunto de parâmetros que podem influir sobre a produção textual. Nele, observamos três mundos que constituem a situação de ação da linguagem: o físico, o social e o subjetivo.

O mundo físico refere-se ao espaço e ao tempo no qual determinado agente está inserido no momento da sua produção textual. Ele pode ser dividido em quatro parâmetros: o lugar de produção, ou seja, o local físico em que o texto é produzido; o momento da produção, que se refere ao período no qual o texto é produzido; o emissor ou produtor, isto é, é a pessoa que produz o texto; e o receptor, as pessoas que recebem o texto.

Como ressalta Bronckart (2007), a produção de todo texto resulta em uma interação comunicativa, implicando assim, o mundo social e o mundo subjetivo. Esse contexto sociossubjetivo definido pelo autor como "a imagem que o agente dá de si ao agir" (BRONCKART, 2007, p. 94) pode ser dividido em quatro parâmetros maiores: o lugar social, a posição social do emissor, a posição social do receptor e o objetivo. O lugar social se refere ao modo de interação em que o texto é produzido, como por exemplo, uma interação informal ou uma interação comercial. A posição social do emissor é o papel social em que o emissor está inserido no momento da interação e que

\footnotetext{
${ }^{6}$ Grifo do autor.
} 
dá ao emissor o estatuto de enunciador. A posição social do receptor é o papel social em que a pessoa que recebe o texto está inserida e que, consequentemente, lhe dá o papel de destinatário. Por fim, o objetivo é o efeito ou são os efeitos que o texto pode causar em um destinatário. É importante ressaltar que as dicotomias entre emissor X enunciador e receptor $\mathrm{X}$ destinatário são propostas a título de reconhecimento do papel desempenhado por alguma pessoa ao produzir ou receber um texto. Evidentemente, como salienta Bronckart (2007), salvo casos de co-escritura ou de macro-enunciação (por exemplo, um jornal), o emissor e enunciador são, geralmente, uma entidade única, assim como o receptor e o destinatário.

Posteriormente à análise do contexto de produção físico e sociossubjetivo, faz-se necessário analisar como se realiza a organização do texto. Para Bronckart (2007), a organização textual se realiza como um folhado em que três camadas são sobrepostas. Elas serão descritas nas seções seguintes: a infraestrutura geral do texto, os mecanismos de textualização e os mecanismos enunciativos.

\subsection{A infraestrutura geral do texto}

A infraestrutura geral de um texto refere-se, segundo Bronckart (2007), à análise do nível global do texto. Esse nível é constituído pelo plano geral, pelos tipos de discurso e pelas sequências mobilizadas no texto. O plano geral se refere à forma como os temas são dispostos no texto, em outras palavras, poderíamos chamar o plano geral como organização dos conteúdos temáticos. Em uma receita, por exemplo, temos: ingredientes e, em seguida, o modo de preparo.

Os tipos de discurso são, segundo o autor "formas específicas de semiotização ou de colocação em discurso dependentes do leque dos recursos morfossintáticos de uma língua" (2007, p. 138). Essas formas, ou segmentos de textos, comportam mundos discursivos constitutivos de um gênero. Os tipos do discurso são pertencentes a dois eixos maiores: o mundo da ordem do narrar e o mundo da ordem do expor. Os mundos discursivos são "interpretados sempre à luz dos critérios de validade do mundo ordinário" (BRONCKART, 2007, p. 154). Assim, o mundo do narrar pode ser considerado disjunto por razão de ter, no ato de ação da linguagem, um distanciamento do mundo ordinário, ao passo que o mundo do expor, é conjunto. Seguindo esses parâmetros, a ficção, por exemplo, pode ser considerada característica do gênero dos 
mundos do narrar, ao passo que nos mundos da ordem do expor, ela será validada na construção conjunta ao da situação de produção, sendo, possivelmente considerada como falsa.

Além disso, esses mundos - o do narrar e do expor - podem ser subdivididos em duas outras categorias, as da implicação ou não no ato de produção. Assim, temos o narrar implicado, o narrar autônomo, o expor implicado e o expor autônomo. Segundo o autor, "esses mundos, assim como as operações em que se baseiam não são, entretanto, identificáveis, senão a partir das formas linguísticas que os semiotizam, sendo eles, portanto, dependentes das formas linguísticas" (Bronckart, 2007, p.155). Nesse sentido, identificamos a implicação ou autonomia no ato da produção na observação da existência ou não de dêiticos temporais, espaciais e de pessoa. É na identificação das coordenadas gerais dos mundos (Expor/conjunção e narrar/disjunção) e na relação com o ato de produção (implicação ou autonomia) que conseguimos identificar os tipos de discurso: o discurso interativo, o discurso teórico, o narrar interativo e a narração.

Quadro 3: Os mundos discursivos

\begin{tabular}{|l|l|l|l|}
\hline \multirow{2}{*}{$\begin{array}{l}\text { Relação ao ato de } \\
\text { produção }\end{array}$} & \multicolumn{3}{|c|}{ Coordenadas gerais dos mundos } \\
\cline { 2 - 4 } & & $\begin{array}{l}\text { Conjunção } \\
\text { EXPOR }\end{array}$ & $\begin{array}{l}\text { Disjunção } \\
\text { NARRAR }\end{array}$ \\
\cline { 2 - 4 } & Implicação & Discurso interativo & Relato interativo \\
\cline { 2 - 4 } & Autonomia & Discurso teórico & Narração \\
\hline
\end{tabular}

(BRONCKART, 2007, p. 157)

Além dos conteúdos temáticos e dos tipos do discurso, Bronckart (2007), tomando por base os estudos de Adam (1996), propôs a noção de sequência, que completa a infraestrutura geral dos textos. Segundo Bronckart (2007), as sequências são modos de planificação textual, ou o que poderíamos chamar de organização sequencial dos conteúdos. Elas são classificadas em narrativa, descritiva, argumentativa, explicativa e dialogal. Bronckart com base em Adam ressalta que

"essas diferentes sequências podem ser combinadas em um texto, em várias modalidades (encaixamento hierárquico, mesclas, etc.), e é da diversidade das sequências e da diversidade de suas modalidades de 
articulação que ocorre a heterogeneidade composicional da maioria dos textos" (BRONCKART, 2007, p. 219).

A sequência narrativa caracteriza-se por apresentar como componente a intriga. Embora, como salienta Bronckart (2007), muitas histórias tenham personagens implicados em acontecimentos sucessivos, ela só é considerada narrativa se, a partir de um momento equilibrado, houver uma tensão que desencadeie em uma ou várias transformações.

A sequência descritiva é caracterizada por ser composta por fases e, diferentemente da sequência narrativa, ela não tem a obrigatoriedade de seguir uma ordem linear; no entanto, essas fases se articulam de maneira hierárquica. Em sua forma prototípica, ela comporta três fases: a fase de ancoragem em que o tema ou o título é assinalado; a fase de aspectualização, onde os temas são enumerados; a fase de relacionamento, em que há uma assimilação entre os elementos descritos.

Assim como a sequência descritiva, que é composta por fases em sua forma prototípica, a sequência argumentativa compõe-se de quatro fases: a fase de premissas em que há uma constatação de partida; a fase de argumentos, ou seja, de componentes que se direcionam à uma conclusão; a fase de apresentação de contra-argumentos, em que os elementos produzem uma restrição; a fase de conclusão, em que os efeitos dos argumentos e contra-argumentos são assimilados.

No que se refere à sequência explicativa, Bronckart (2007) retoma o raciocínio explicativo apresentado por Grize (1981b), em que em uma dada constatação ou fenômeno incontestável apresentam-se como incompleto e se é legitimado pelo agente a partir da explicitação de causas e ou razões dessa constatação fazendo que, no fim desse desenvolvimento, as constatações sejam reformuladas. Assim, a sequência explicativa, em seu protótipo, é composta por quatro fases: a fase de constatação inicial; a fase de problematização; a fase de resolução e a fase de conclusão-avaliação.

Para finalizar os tipos de sequência, temos a sequência dialogal, que, como salienta Bronckart, caracteriza-se por "concretizar-se apenas nos segmentos interativos dialogados" (2007, p. 230). Os segmentos são estruturados em turnos de fala, podendo concretizar-se como discursos interativos primários ou discursos interativos secundários. Nos primários, os agentes-produtores efetivam os turnos de fala na interação verbal e, nos secundários, os turnos de fala são efetivados no discurso de personagens. Esse tipo de sequência pode ser dividido em três fases em seu protótipo: 
uma fase de abertura, na qual os personagens representados entram em contato; uma fase transacional, em que o tema é construído entre os personagens; uma fase de encerramento, em que se finaliza a interação. Essa sequência é importante para nosso trabalho, pois, justamente, os tutoriais em vídeo se organizam primeiramente em sequências dialogais.

Com os tipos de sequência, finalizamos assim, a primeira camada do folhado textual do modelo de análise do ISD. Na próxima seção, traremos a segunda camada referente aos mecanismos de textualização.

\subsection{Os mecanismos de textualização}

Os mecanismos de textualização fazem parte do segundo nível do folhado textual concebido por Bronckart (2007). Eles são as unidades responsáveis pela coerência textual que auxiliam na progressão dos conteúdos temáticos. Segundo Bronckart (2007), os mecanismos de textualização podem ser classificados em três conjuntos maiores: a coesão nominal, a coesão verbal e a conexão.

Os mecanismos de conexão são articuladores responsáveis pela progressão temática. São eles os responsáveis pelas transições entre os elementos constitutivos de um texto, tanto no que se refere às fases de uma sequência, os tipos de discurso ou outras formas de planificação. A organização temática pode ser feita por organizadores lógicos, espaciais e temporais.

Por fim, os mecanismos coesivos, por sua vez, são caracterizados por marcar "relações de dependência ou/e descontinuidade entre dois subconjuntos de constituintes internos à estrutura de frase" (BRONCKART, 2007, p.263). Os mecanismos de coesão nominal introduzem uma informação e organizam a retomada dessa informação no texto através de anáforas. Já os mecanismos de coesão verbal são responsáveis pela progressão no tempo. Assim, é através dos tempos verbais e dos auxiliares que produzimos em um texto, que asseguramos a noção de continuidade e de descontinuidade. 


\subsection{Os mecanismos enunciativos}

A terceira e última camada do folhado textual é composta pelos mecanismos enunciativos. Esses mecanismos, segundo Bronckart (2007) contribuem para a coerência pragmática textual com explicitações de julgamentos, opiniões e sentimentos do produtor em relação aos conteúdos temáticos do texto. Nesse momento da análise, verificamos as vozes e as modalizações presentes no texto. As modalizações podem ser lógicas, pragmáticas, deônticas e apreciativas. As modalizações lógicas são as avaliações de algum aspecto do conteúdo temático apoiadas nos conhecimentos elaborados e organizados no quadro das coordenadas presentes no mundo objetivo, ou seja, apresentam elementos que atestam um ponto de vista, fatos atestados, necessários, possíveis etc. As modalizações deônticas, por sua vez, são avaliações apoiadas em valores, regras que provem do mundo social. Nelas, observamos por exemplo, elementos constitutivos do direito e das normas de uso. As modalizações apreciativas se referem à avaliação proveniente do mundo subjetivo da entidade responsável pelo julgamento, podendo ser, por exemplo, considerado como algo benéfico, estranho, assustador etc. Por fim, as modalizações pragmáticas, de acordo com Bronckart, "contribuem para a explicitação de alguns aspectos da responsabilidade de uma entidade constitutiva do conteúdo temático em relação às ações de que é o agente" (2007, p. 332). Essa explicitação pode atribuir ao agente, por exemplo, razões ou capacidades de ação.

As vozes enunciativas, por sua vez, são as entidades que se responsabilizam pelo que é expresso no texto e, na maioria dos casos, conforme Bronckart (2007), temos a voz chamada de neutra, em que a instância geral assume a responsabilidade da enunciação. Em outros casos, a instância de enunciação pode dispor de outras vozes. Essas vozes enunciativas são reagrupadas em três subconjuntos: vozes de personagens, vozes de instâncias sociais e voz do autor empírico do texto (Bronckart, 2007, p. 326). Além disso, Bronckart (2007), menciona que existem duas formas de expressão das vozes: i) as vozes diretas, presentes em discursos interativo dialogados, ou seja, que caracterizam-se por serem explícitas. ii) as vozes indiretas, encontradas em qualquer tipo de discurso e demandam uma atenção maior para sua identificação. $\mathrm{O}$ autor salienta ainda que um texto pode apresentar várias vozes distintas, podendo ser explícita ou implícita: a polifonia. 
No entanto, o autor não desenvolve essas vozes e, por essa razão, nos embasamos em Authier-Revus (2001) no que concerne à heterogeneidade constitutiva (não-coincidências do dizer) devido a sua presença nos tutoriais em vídeos analisados, como veremos em nossas análises. Segundo a autora (2001, p. 20), na heterogeneidade constitutiva os comentários metaenunciativos não são observáveis em sua estrutura sintática, mas em máscaras que denotam uma negociação do enunciador com as nãocoincidências presentes no seu dizer. Ela divide a heterogeneidade em quatro itens (AUTHIER-REVUZ, 2001, p. 21):

a) A não-coincidência interlocutiva, observáveis por expressões como: $\mathrm{X}$, se entende o que eu quero dizer; como você acaba de dizer; digamos X.

b) A não coincidência consigo mesmo, que se traduz pelas noções do dialogismo bakhtiniano de interdiscurso, ou seja, que todo discurso é atravessado pelo discurso do outro, do já dito.

c) A não coincidência ente as palavras e as coisas, observáveis por expressões como ouso dizer X; por assim dizer; o que é preciso chamar X; e pelas metáforas, eufemismos, neologismos etc.

d) A não-coincidência das palavras consigo mesmas, traduzidas por expressões como eu falhei dizendo $\mathrm{X} ; \mathrm{X}$, sem jogo de palavra, etc.

Nesta seção, trouxemos os três extratos do folhado textual para nos auxiliar na elaboração do MD do gênero tutorial em vídeos. Tal como salientado, para complementar a análise, já que a análise do ISD privilegia os aspectos verbais do texto, recorremos à união proposta por Leal (2011) do quadro de análise do ISD e das categorias de análise da Gramática do Design Visual para interpretar os elementos não verbais. Dedicaremos a seção seguinte às categorias de análise da Gramática do Design Visual.

\section{A Gramática do Design Visual}

A Gramática do Design Visual (GDV) foi concebida com base nos pressupostos da Linguística Sistêmico Funcional postulada por Halliday (1985), na qual a linguagem é organizada de acordo com uma função e essa organização está relacionada à construção do texto. A Linguística Sistêmico Funcional concebe o uso da língua de forma semelhante à do ISD e, por isso, Leal (2011) afirma que elas podem ser articuladas. 
Segundo Kress e Van Leeuwen (2006), os significados são representações construídas culturalmente e, assim como na linguagem em que determinadas escolhas lexicais e estruturas oracionais afetam uma informação que se quer passar, na comunicação visual, o tamanho de uma imagem, suas cores e suas estruturas composicionais afetam o significado do texto. Assim, os autores ressaltam que as imagens também possuem uma gramática e que, através delas, podemos passar, por exemplo, significados como a ironia.

Para o ISD, a gramática é considerada como um aspecto específico e sua análise fundamenta-se, em um primeiro momento, nos mundos discursivos que são semiotizados pelos tipos do discurso. Diante disso, é importante esclarecer que a gramática visual, na perspectiva dos autores da GDV, “descreve um recurso social de um grupo particular, de seu conhecimento explícito e implícito sobre esse recurso, e de seu uso nas práticas sociais desse mesmo grupo" (LEAL, 2011, p.175). Assim, ela não pode ser relacionada a uma gramática normativa, tal como postulado pelo ISD, pois a GDV tem como objetivo analisar os diferentes elementos semióticos com base em seu uso, trazendo recursos teóricos para interpretar variados textos multimodais, como por exemplo, cartazes, mapas e layouts em revistas.

Diante do contexto tecnológico no qual estamos inseridos e da quantidade de textos multimodais aos quais temos acesso, segundo Kress e Van Leeuwen (2006), temos a necessidade de um letramento visual. Esses autores postulam que ser letrado verbal e visualmente começa a ser uma questão de sobrevivência, principalmente em relação ao mercado de trabalho. Com base na Semiótica Social, a noção de multimodalidade na GDV refere-se à comunicação humana realizada na articulação de diferentes modos, tanto na linguagem verbal, como pela linguagem visual, como por exemplo, gestos, elementos icônicos etc.

Baseados nas metafunções interpessoal, ideacional e textual propostas por Halliday (1985), Kress e Van Leeuwen (2006) propõem uma análise semiótica dos textos verbais e não verbais através das representações coletivas e individuais. Assim, temos como resultado outras metafunções chamadas pelos autores de interacional, representacional e composicional. Para a compreensão dessas metafunções, na seção seguinte, traremos a noção de participantes. 


\subsection{Os participantes na Gramática do Design Visual}

Como a GDV analisa as representações presentes na cena comunicativa com base nas relações estabelecidas entre os elementos que compõem essa cena, faz-se necessário trazer a noção de participantes (KRESS; VAN LEEUWEN, 2006). Os participantes são os elementos presentes no ato semiótico, podendo ser tanto objetos como pessoas.

Segundo Kress e Van Leeuwen (2006), podemos ter dois tipos de participantes: os participantes interativos e os participantes representados. Os primeiros referem-se tanto ao produtor quanto ao receptor do texto (quem fala, ouve, lê o texto) ao passo que os segundos são os seres animados ou inanimados que estão figurados no texto, sendo os participantes mais importantes do ato semiótico.

Para a compreensão das representações conferidas às imagens, os autores mencionam o modelo de comunicação proposto por Shannon e Weaver (1949). Nesse esquema, que segue abaixo, as caixas representam os participantes e as setas representam os processos que os relacionam. Em comparação com linguagem verbal, como ressaltam os autores (2006), poderíamos dizer que as caixas são os nomes e as setas os verbos, isto é, a junção desses elementos seria equivalente ao que chamamos de orações.

Figura 2: O modelo de comunicação proposto por Shannon e Weaver

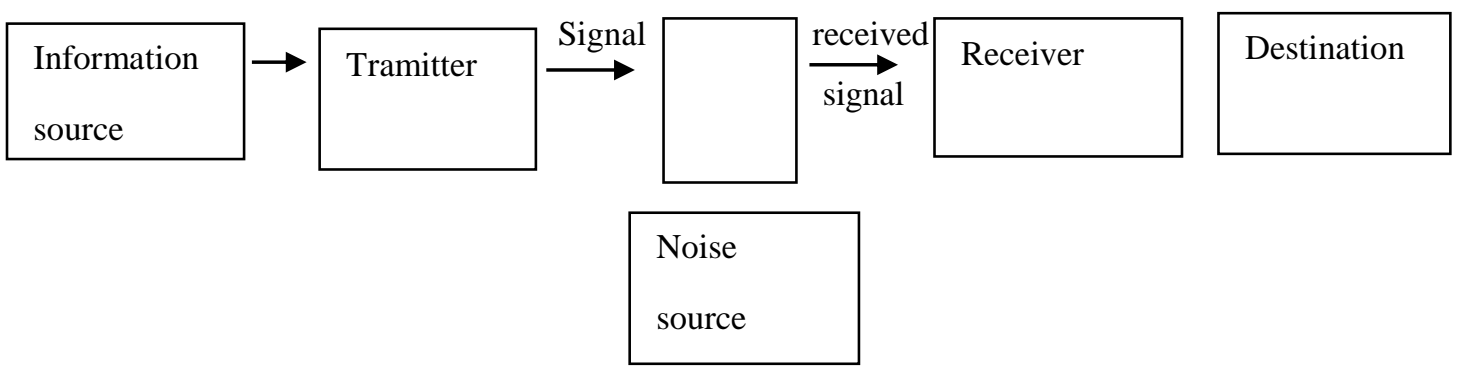

(Reproduzido de KRESS; VAN LEEUWEN, 2006, p. 48)

No entanto, como observado por Kress e Van Leeuwen (2006), esse modelo apresenta limitações ${ }^{7}$ : no caso de imagens naturalistas ou diagramas, por exemplo, teríamos dificuldade de encontrar os participantes, e seria uma tarefa, até mesmo, sem propósito, pois nesses dois casos, a analogia com a língua perde a importância. Assim,

\footnotetext{
${ }^{7}$ Em nosso caso, por exemplo, por nos basearmos no ISD, que tem uma outra concepção da situação de comunicação, também não faria sentido adotar um modelo como este.
} 
para encontrar os participantes na cena comunicativa, os autores apontam duas perspectivas: a primeira, baseada em Arnheim (1974,1982), consiste na ideia de que os participantes podem ser identificados de acordo com sua massa e seu volume. Com base em Halliday (1978/1995), o outro aspecto a ser observado consiste na identificação dos papeis semânticos e funcionais atribuídos à imagem, tendo assim dois tipos de participantes: os atores, aqueles que agem, e metas, a direção da ação. Entre os atores e metas, temos o que os autores chamam de processo.

\subsection{A função representacional}

Proposta por Kress e Van Leeuwen (2006), a função representacional apresenta as relações entre os participantes na cena comunicativa, os seus elementos e suas circunstâncias. Essas representações, como salienta Leal (2011), em correlação com a metafunção ideacional, se manifestam na GDV como "a habilidade do sistema semiótico para representar objetos e suas relações no mundo dentro de um sistema representacional" (2011, p. 179). As representações na imagem podem ser divididas em duas categorias: as narrativas e conceituais.

As representações narrativas são reconhecidas por apresentarem vetores. Os vetores são "setas" imaginárias, isto é uma ação de um participante a um ser animado ou inanimado que acontece na cena comunicativa. O participante do qual parte o vetor é reconhecido na imagem como o ator e o participante ao qual o ator direciona sua ação, a meta. Nas representações narrativas, como postulam os autores da GDV (2006), podemos encontrar diferentes processos, a saber: de ação, reação, verbal, mental e conversão. Outro fator que o analista deve observar são as circunstâncias, tais como o cenário, a significação e o acompanhamento.

O processo de ação pode ser transacional ou não-transacional. O processo de ação não-transacional pode ser identificado quando a imagem apresenta um participante - ator - em ação, mas não conseguimos identificar a meta, ou seja, para quem ou para que o ator direciona sua ação. Kress e Van Leeuwen (2006), a título de compreensão, comparam as imagens narrativas não-transacionais com os verbos intransitivos da linguagem verbal (exemplo, it rains ou it snows no inglês), fazendo a ressalva, evidentemente, que os verbos intransitivos em uma língua, pode ser transitivos em outras línguas (no caso do chinês, por exemplo). 
Outro tipo de não-transacionalidade pode ser observado em imagens em que não podemos identificar o ator na cena, mas o processo - a ação - e a meta. São os casos, por exemplo, em que podemos observar partes do ator, como as mãos, os dedos, mas eles continuam anônimos na cena comunicativa (Kress e Van Leeuwen, 2006). O processo de ação transacional, por sua vez, caracteriza-se por apresentar os dois participantes, ou seja, é possível observar visualmente tanto o ator, quanto o vetor e a meta.

O processo de reação, por sua vez, se manifesta nas cenas em que podemos observar vetores que provém do olhar de um participante a outro. Como no processo anterior, podemos caracterizá-los como transacionais e não-transacionais: quando visualizamos os dois participantes e os vetores; ou quando não conseguimos visualizar a meta ou o ator.

A terceira categoria postulada pelos autores, o processo verbal pode ser identificado, por exemplo, por apresentar balões utilizados em revistas em quadrinhos que demarcam a fala dos participantes representados. Semelhante ao processo verbal, o processo mental também apresenta balões, no entanto, no lugar de falas, temos os pensamentos ou sentimentos dos participantes.

Por fim, o último processo das representações narrativas denominado como processo de conversão é caracterizado quando um dos participantes é tanto ator e meta de um outro ator, ou seja, ele pode ocorrer de maneira concomitante com o processo de ação ou de reação.

As representações narrativas, como postulam Kress e Van Leeuwen (2006), podem apresentar outros elementos que não estão figurados no ato semiótico, as chamadas circunstâncias (Halliday, 1985). Por serem caracterizadas pela ausência de vetores, elas podem ser denominadas como participantes secundários e podem ser divididos em Setting, Means e Accompaniment.

O Setting, traduzido por Leal como "cenário" (2010, p. 185), concerne à ambientação na imagem, seja ela apresentada em segundo plano, ou que apresente poucos detalhes, quando ele é ausente (em imagens com uma única cor de fundo, por exemplo) e quando ele está em destaque. O outro tipo de categoria da circunstância refere-se aos recursos que transmitam alguma informação. Assim, por exemplo, em uma cena que apresente dois participantes em um diálogo, poderíamos dizer que o diálogo é a ação e os gestos significativos nessa circunstância. 
O último tipo, o "acompanhamento" (LEAL, 2010, p.185), caracteriza-se por ser um participante que não apresenta nem recebe vetores que emanam de outros participantes.

Diferentemente das representações narrativas, as conceituais caracterizam-se pela ausência de participantes, consequentemente, pela não aparição de vetores no ato semiótico. Na GDV (2006) os autores separam-nas em três categorias: a classificacional, a analítica e a simbólica.

O processo denominado classificacional, refere-se aos participantes quando definidos de forma taxionômica, ou seja, levado pelo critério das características do grupo ao qual pertencem. Elas podem ser divididas em duas categorias: taxionômica fechada quando os elementos apresentam simetria entre eles verticalmente e horizontalmente - e taxionômica aberta - quando há uma hierarquização entre os elementos presentes no texto.

Quando no processo há uma relação entre os participantes, por sua vez, ele é nomeado como analítico. Segundo Kress e Van Leeuwen (2006), nesse processo encontramos dois tipos de participantes: o portador, aquele representante do todo, e os atributos possessivos, os que representam a parte.

O processo simbólico caracteriza-se por apresentar um realce ou uma nuance dos participantes presentes no texto. Podemos, por exemplo, observar um tamanho exagerado ou ainda valores simbólicos associados à uma determinada cultura. Em relação à nuance, nos referimos, por exemplo a um traço que pode identificar a identidade do portador.

\subsection{A função interativa}

Para os autores da GDV (KRESS; VAN LEEUWEN, 2006), através de uma imagem é possível interpretar a interação entre os participantes, tanto entre participantes interativos, participantes representados e interativos, como somente entre participantes representados. Responsável por apresentar elementos que marcam uma certa aproximação ou distanciamento entre os participantes, a função interativa, pode mostrar também a visão do produtor sobre algo. Elas podem ser divididas em três recursos: o Contato, a Distância Social e a Atitude ou perspectiva. Ainda na função interativa, Kress e Van Leeuwen (2006) postulam uma outra função: a modalidade. Essa função será descrita mais à frente. 
Divididos em duas outras subcategorias - a exposiçãoloferta e interpelação /demanda - o contato é determinado pelo olhar dos participantes. A interpelação/demanda acontece quando há uma conexão imaginária através do olhar ou dos gestos entre o participante interativo e o leitor da imagem. A exposição/oferta é muito comum, por exemplo, em filmes em que o leitor é um espectador, ou seja, ele não participa ativamente da cena comunicativa. Nela, o participante representado não se "conecta" com o leitor da imagem, ele é apenas observado.

Assim como o contato sugere uma aproximação entre os participantes no ato semiótico, a distância social contribui também para essa interpretação. Interpretada através dos planos de cinema (KRESS; VAN LEEUWEN, 2006), ela é dividida em três planos: o fechado, o médio e o geral.

Também chamado de close-up, o plano fechado caracteriza-se por uma grande aproximação e, normalmente a pessoa é retratada do rosto até a altura dos ombros. Esse plano sugere uma aproximação afetiva e um grau de intimidade elevado entre aquele que observa e o participante representado. No plano médio, por sua vez, temos um grau de envolvimento moderado. Conhecido também como plano americano, essa categoria pode ser reconhecida em imagens em que a pessoa aparece na altura da cintura ou do joelho. Por fim, o plano geral sugere o contrário do plano fechado: não há aproximação e pode sugerir certa distância social. Normalmente, as pessoas são retratadas de corpo inteiro e se dá certa ênfase ao cenário.

Na última categoria, a atitude ou perspectiva, observamos os ângulos sob os quais os participantes representados se situam e podemos dividi-la em duas subcategorias: a objetiva e a subjetiva. Na primeira subcategoria, não há ângulos como na segunda. Ela pode ser encontrada, por exemplo, em manuais de instrução, em guias, ou dicionários ilustrados. Contrariamente à objetiva, a subjetiva apresenta três ângulos podendo sugerir um olhar do mundo do produtor, bem como o grau de relação entre os participantes. Os ângulos são estes: frontal, oblíquo e vertical.

O primeiro ângulo, o frontal, pode sugerir uma relação de igualdade e/ou envolvimento, ao passo que o oblíquo revela um distanciamento entre os envolvidos no ato semiótico. O ângulo vertical também sugere a relação entre os envolvidos e através dele, podemos perceber as relações de poder. Eles são divididos em ângulos alto, médio e baixo: o ângulo alto (imagem captada de baixo para cima) pode sugerir que o leitor é o detentor do poder; no ângulo médio (imagem em que os participantes estão no mesmo 
nível) aponta para uma relação igualitária; por fim, o ângulo baixo, (imagens captadas de baixo) sugere que o participante detém o poder em relação ao leitor.

A última categoria postulada pelos autores (KRESS; VAN LEEUWEN, 2006) na função interativa, refere-se à modalidade. Ela se caraterizada por apresentar o grau de realidade na imagem, isto é, como postula Leal, há "uma escala que vai do mais próximo do real até a abstração total da imagem" (2010, p.196). Podemos analisá-la através de quatro marcadores: a cor, a contextualização, a representação, a profundidade, a iluminação e o brilho: a cor refere-se aos níveis de saturação podendo haver cor plena ou ausência dela, a diferenciação pode ser observada em imagens monocrômicas ou que apresentam policromia e a modulação pode ser encontrada tanto na sombra à cor plena; a contextualização é um marcador do cenário, podendo ser tanto ausente como detalhado, ou minimamente estruturado; a representação refere-se à máxima abstração ou máxima representação dos elementos pictóricos; a profundidade é a modalidade da profundidade da cena; a iluminação pode ser também apresentada em graus, mostrando o olhar do produtor sobre a cena; por fim, o brilho, pode se apresentar numa escala de tons de cinza ou branco.

\subsection{A função composicional}

A última função das imagens, a composicional, articula as funções representacional e interacional, portanto, nela verificamos como os variados elementos se articulam no texto, tanto os elementos verbais e os não verbais (KRESS; VAN LEEUWEN, 2006). Nesse momento da análise, podemos observar três fatores: o valor da informação, a saliência e o emolduramento.

O primeiro fator refere-se aos lugares em que os elementos estão dispostos no texto, podendo ser centrado ou polarizado. Seguindo o sistema da leitura ocidental, o modo polarizado pode remeter às informações já conhecidas - normalmente dispostas à esquerda - e as informações novas - à direita. Ele pode ser verificada também nas informações que estão dispostas na parte superior e inferior, supondo que, na parte superior, são dispostos os elementos de menor grau de informação e no inferior, os detalhes ou informações técnicas. A saliência, por sua vez, é o fator que tem como intuito focar a atenção do leitor em algum elemento específico do texto, podendo ser observado 
tanto o tamanho, o foco e a perspectiva. Por fim, o emolduramento refere-se à interligação ou não dos elementos no texto.

\section{O modelo de análise Semiótico Sociointeracional}

Como salientado anteriormente, como os tutoriais articulam, em sua construção, elementos verbais e não verbais, faz-se necessário utilizar uma abordagem em que os dois elementos são explorados. Nesse sentido, baseando-nos em Leal (2011), traremos o quadro da Semiótica Interacional, no qual a autora sugere a junção da análise textual do Interacionismo Sociodiscursivo, que propõe a análise do texto verbal, e das funções da Gramática do Design Visual, que analisa o texto não verbal.

\subsection{O contexto de produção, recepção e plano global dos conteúdos temáticos}

No ISD (BRONCKART, 2006), vimos que a ação de linguagem compreende o contexto de produção e seus parâmetros objetivos, sociossubjetivos e as representações que permeiam o agente-produtor. No entanto, como observa Leal (2011, p.202), “o nosso acesso ao texto sempre será feito enquanto receptores do mesmo", sendo de importância para sua compreensão também as condições em que esse texto foi produzido. Assim, a análise do contexto assume dois lados: o contexto de produção e o contexto de recepção.

Desse modo, no contexto de produção descrito por Bronckart (2006), foram acrescentados a atividade na qual o texto é produzido, o gênero textual e o suporte de publicação. O contexto de recepção (Leal, 2011) também traz a atividade, o gênero e a publicação, bem como o contexto físico e social. Assim, esse contexto também será dividido em quatro categorias, como podemos ver no quadro abaixo: 
Quadro 4: Os contextos de produção e de recepção

\begin{tabular}{|c|c|c|c|c|}
\hline \multirow{4}{*}{$\begin{array}{l}\text { Atividade(s) } \\
\text { relacionadas(s) }\end{array}$} & \multirow{4}{*}{$\begin{array}{c}\text { Gênero } \\
\text { escolhido } \\
\text { e } \\
\text { suporte } \\
\text { definido }\end{array}$} & \multirow[t]{2}{*}{$\begin{array}{c}\text { Contexto } \\
\text { de } \\
\text { produção }\end{array}$} & Contexto físico & $\begin{array}{l}\text { Lugar de produção } \\
\text { Meio de produção } \\
\text { Produtor, receptor }\end{array}$ \\
\hline & & & $\begin{array}{l}\text { Contexto } \\
\text { Sociossubjetivo }\end{array}$ & $\begin{array}{l}\text { Lugar social da produção } \\
\text { Posição social do produtor e } \\
\text { do receptor } \\
\text { Objetivo (s) }\end{array}$ \\
\hline & & \multirow[t]{2}{*}{$\begin{array}{l}\text { Contexto } \\
\text { de } \\
\text { recepção }\end{array}$} & Contexto físico & $\begin{array}{l}\text { Lugar de recepção } \\
\text { Momento de recepção } \\
\text { Receptor e produtor }\end{array}$ \\
\hline & & & $\begin{array}{l}\text { Contexto } \\
\text { sociossubjetivo }\end{array}$ & $\begin{array}{l}\text { Lugar social da recepção } \\
\text { Posição social do receptor e } \\
\text { do produtor } \\
\text { Objetivo (s) }\end{array}$ \\
\hline
\end{tabular}

(LEAL, 2011, p. 202)

Ainda no contexto de produção e recepção, podemos observar a organização dos conteúdos temáticos mencionados anteriormente. O conteúdo temático refere-se, segundo Leal, "ao conhecimento do indivíduo adquirido no meio social e cultural manifestado no texto e que é, de certa maneira, recuperado pelo receptor” (2011, p. 204), assim é possível recuperar as representações construídas pelo autor na relação entre o conhecimento prévio e o contexto no qual o texto foi produzido.

\subsection{A arquitetura interna dos textos multimodais}

Nesta seção, traremos o quadro da Semiótica Sociointeracional concebido por Leal (2011) em sua tese de doutorado sobre o gênero textual Cartoon. Salientamos, novamente, que a junção da análise textual do Interacionismo Sociodiscursivo e das funções da Gramática do Design Visual só foi possível pela compatibilidade epistemológica das teorias para as quais os textos são vistos como resultados de práticas sociais. 
Quadro 5: O Quadro da Semiótica Sociointeracional

\begin{tabular}{|c|c|c|}
\hline ISD & GDV & Semiótica Sociointeracional \\
\hline $\begin{array}{l}\text { Infraestrutura } \\
\text { a) Organização temática; } \\
\text { b) Organização } \\
\text { discursiva; }\end{array}$ & $\begin{array}{l}\text { Representacional } \\
\text { a) Narrativas; } \\
\text { b) Conceituais; }\end{array}$ & $\begin{array}{l}\text { Organização Temático-representacional: modos } \\
\text { de pôr os discursos em representações sociais: } \\
\text { a) Organização Temático não verbal; } \\
\text { b) Organização temático verbal; }\end{array}$ \\
\hline $\begin{array}{l}\text { Mecanismos Enunciativos } \\
\text { a) Responsabilidade } \\
\text { enunciativa; } \\
\text { b) Distribuição de vozes; } \\
\text { c) Modalidade/ } \\
\text { modalização; }\end{array}$ & $\begin{array}{l}\text { Interativa: } \\
\text { a) Contato; } \\
\text { b) Distância social; } \\
\text { c) Perspectiva; } \\
\text { d) Modalidade; }\end{array}$ & $\begin{array}{l}\text { Organização Interacional: modos de } \\
\text { manifestação da interação: } \\
\text { a) Manifestação da interação pelo verbal; } \\
\text { b) Organização de manifestação pelo não } \\
\text { verbal. }\end{array}$ \\
\hline $\begin{array}{l}\text { Mecanismos } \\
\text { textualização } \\
\text { a) Conexão; } \\
\text { b) Coesão Nominal }\end{array}$ & $\begin{array}{l}\text { Composicional: } \\
\text { a) Valor da informação; } \\
\text { b) Saliência; } \\
\text { c) Estruturação; }\end{array}$ & $\begin{array}{l}\text { Organização estrutural: modos de configuração } \\
\text { dos estruturais: } \\
\text { a) estruturação verbal; } \\
\text { b) Estruturação não-verbal }\end{array}$ \\
\hline
\end{tabular}

(LEAL, 2011, p. 205)

$\mathrm{Na}$ primeira coluna, temos os componentes da arquitetura interna dos textos do ISD e ne segunda coluna, os componentes da GDV e suas metafunções. Na terceira coluna, denominada por Leal como Semiótica Interacional (2011), temos a junção dos dois modelos de análise, resultando em organização temático-representacional, organização interacional e organização estrutural.

\subsubsection{A organização temático-representacional}

A organização temático-representacional compreende as formas de colocar em discurso representações de um determinado meio social. Ela, assim como as duas outras categorias, serão interpretadas em duas formas semióticas de representação: as verbais e as não verbais.

Assim, na organização temático-representacional verbal organizam-se os tipos de discurso (implicados ou autônomos e conjuntos ou disjuntos), as sequências mobilizadas (argumentativa, dialogal, injuntiva, descritiva, explicativa e narrativa) e os conteúdos temáticos. $\mathrm{Na}$ organização temático não-verbal, observaremos as representações 
narrativas e conceituais. Dessa forma, neste quadro, conseguiremos analisar as representações sociais presentes pelo não verbal e que podem se relacionar com o aspectos verbais, fornecendo assim, mais informações sobre o contexto (LEAL, 2011). Abaixo, segue o quadro que resume a organização temático-representacional:

Quadro 6: Organização temático representacional

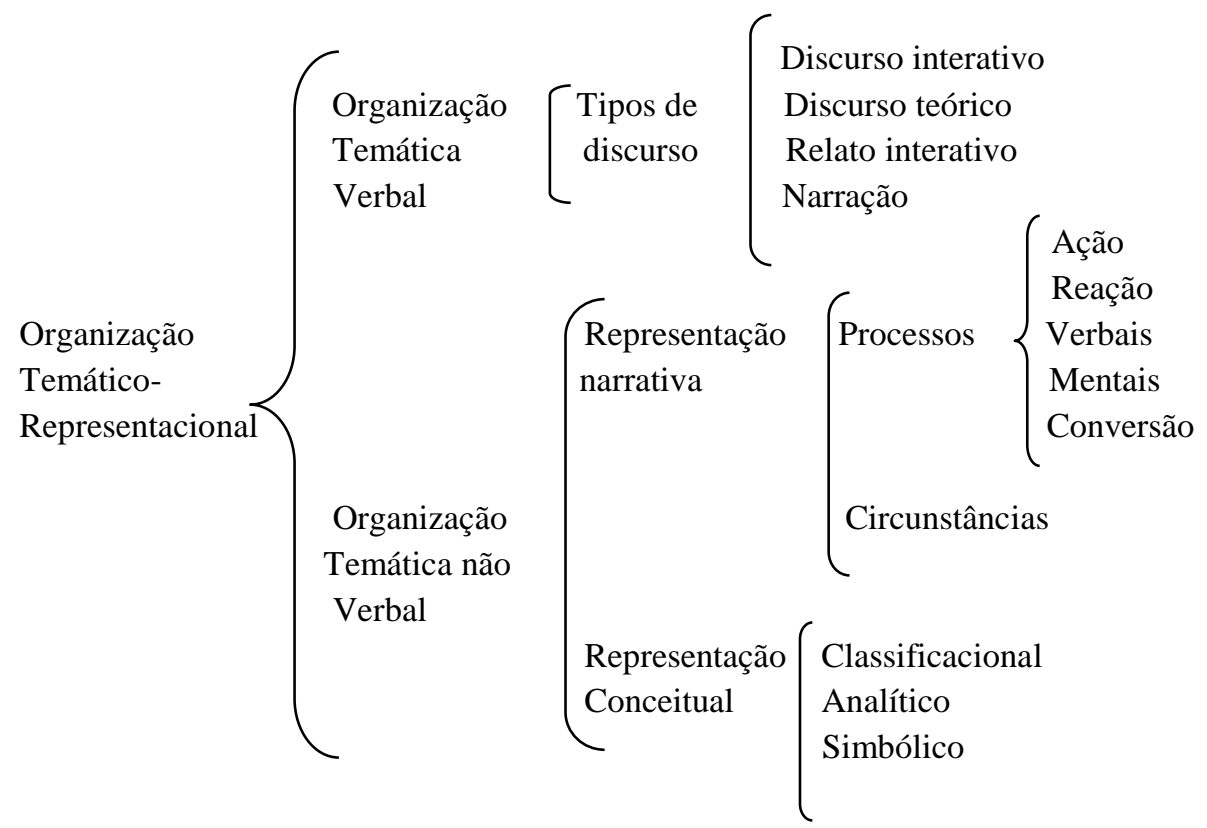

(Leal, 2011, p. 208)

\subsubsection{A organização interacional}

A organização interacional aponta as formas de interação tanto no plano visual como no verbal. Próxima à concepção de Kress e Van Leeuwen (2006), Leal apresenta três formas de interação: entre o autor e o leitor do texto; entre os diferentes elementos semiotizados no texto; entre os participantes representados (os participantes que aparecem no texto) e os participantes interativos (o produtor e o leitor). Dessa forma, na manifestação verbal, observamos as vozes e a modalização, que marcam o dialogismo no texto; no plano visual, temos a organização interacional não-verbal, ou seja as categorias como o contato, a atitude, a distância social e a modalidade, como mostra o quadro abaixo: 
Quadro 7: Organização Interacional

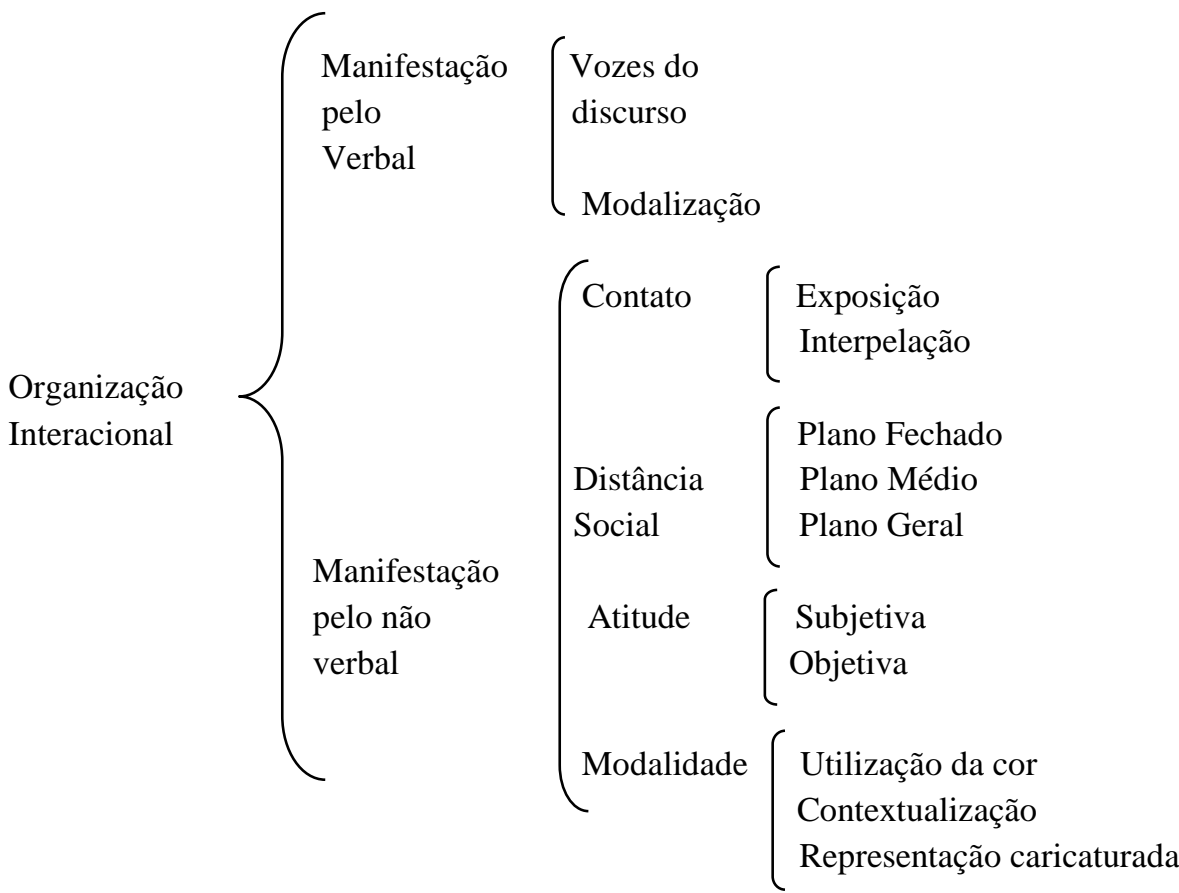

(Leal, 2011, p. 208)

\subsubsection{Organização estrutural}

Por fim, a última categoria postulada por Leal (2011), a organização estrutural, relaciona-se tanto à maneira como o texto é apresentado e à sua construção, isto é, a organização interna. $\mathrm{Na}$ estruturação verbal, temos as unidades responsáveis pela coerência textual, que servem para a progressão do conteúdo temático e que mantém a coesão verbal, nominal e a conexão. Na estruturação não verbal, temos as categorias que analisam a disposição espacial entre os elementos no texto e que auxiliam na compreensão do texto: a informação, a saliência e o emolduramento. 
Quadro 8: Organização Estrutural

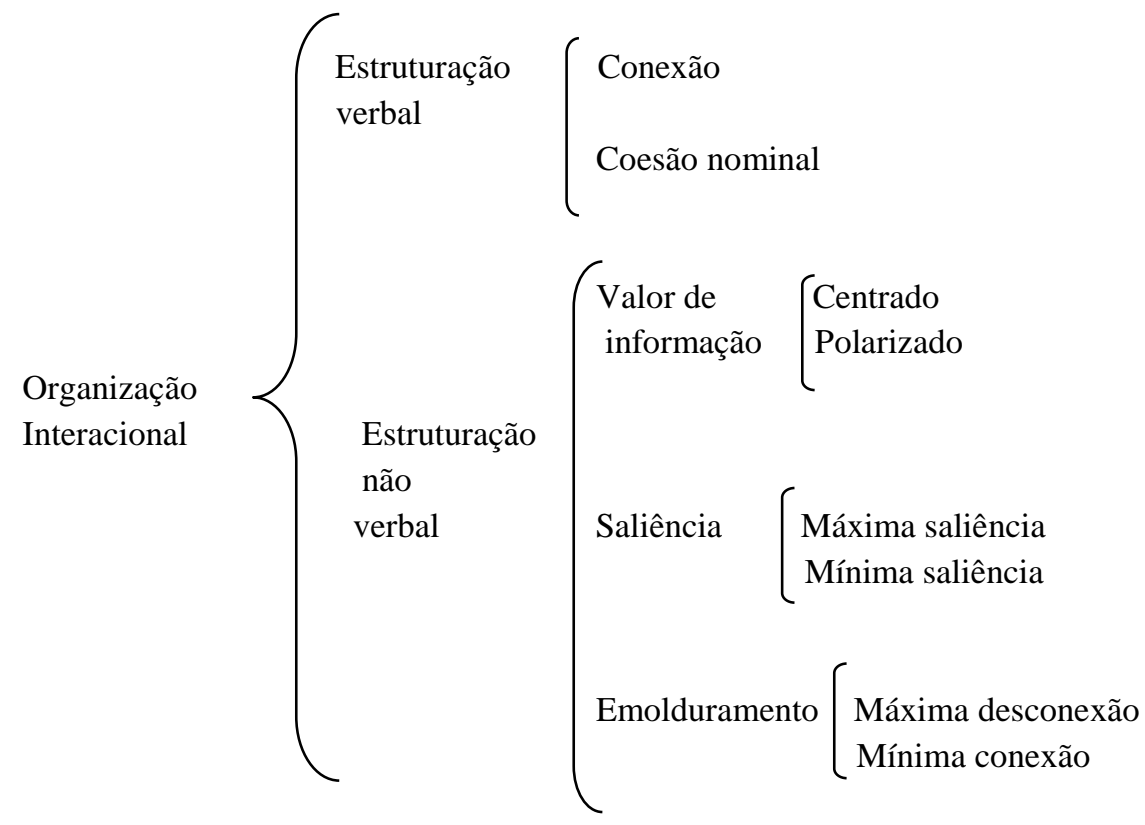

(Leal, 2011, p. 211)

\subsubsection{O quadro global de análise}

Diante do que foi exposto sobre as categorias do modelo de análise Semiótico Sociointeracional, trazemos o quadro global de análise, que aborda o nível de ação da linguagem, a arquitetura interna dos textos e seus modos de planificação, e que foi usado por nós para a análise dos tutoriais. 
Quadro 9: O quadro global de análise

\begin{tabular}{|c|c|c|c|c|c|}
\hline & & & $\begin{array}{l}\text { Contexto de } \\
\text { produção }\end{array}$ & Contexto físico & $\begin{array}{l}\text { Lugar de } \\
\text { produção } \\
\text { Momento de } \\
\text { produção } \\
\text { Produtor } \\
\text { Receptor } \\
\end{array}$ \\
\hline & & Ação de & & $\begin{array}{l}\text { Contexto } \\
\text { sociossubjetivo }\end{array}$ & $\begin{array}{l}\text { Lugar social da } \\
\text { Produção } \\
\text { Posição social do } \\
\text { produtor e receptor } \\
\text { Objetivo }\end{array}$ \\
\hline & & linguagem & Contexto de & Contexto físico & $\begin{array}{l}\text { Lugar de recepção } \\
\text { Momento de } \\
\text { recepção } \\
\text { Receptor } \\
\text { Produtor }\end{array}$ \\
\hline & & & recepção & $\begin{array}{l}\text { Contexto } \\
\text { sociossubjetivo }\end{array}$ & $\begin{array}{l}\text { Lugar social da } \\
\text { recepção } \\
\text { Posição social do } \\
\text { receptor e produtor } \\
\text { Objetivo }\end{array}$ \\
\hline $\begin{array}{l}\text { Atividade(s) } \\
\text { Relacionadas(s) }\end{array}$ & $\begin{array}{l}\text { Gêneros } \\
\text { escolhido } \\
\text { e suporte } \\
\text { definido }\end{array}$ & 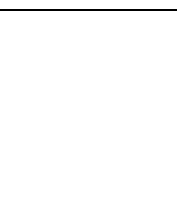 & $\begin{array}{l}\text { Organização } \\
\text { temático- }\end{array}$ & $\begin{array}{l}\text { Organização } \\
\text { temática- } \\
\text { representacional } \\
\text { Verbal }\end{array}$ & Tipos de discurso \\
\hline & & $\begin{array}{l}\text { Arquitetura } \\
\text { interna dos } \\
\text { textos }\end{array}$ & representacional & $\begin{array}{l}\text { Organização } \\
\text { temática- } \\
\text { representacional } \\
\text { Não verbal }\end{array}$ & $\begin{array}{l}\text { Tipos de } \\
\text { Representação }\end{array}$ \\
\hline & & & & $\begin{array}{l}\text { Manifestação } \\
\text { Pelo verbal }\end{array}$ & $\begin{array}{l}\text { Vozes do discurso } \\
\text { Modalidade }\end{array}$ \\
\hline & & & $\begin{array}{l}\text { Organização } \\
\text { Interacional }\end{array}$ & $\begin{array}{l}\text { Manifestação } \\
\text { Pelo não verbal }\end{array}$ & $\begin{array}{l}\text { Contato } \\
\text { Distância social } \\
\text { Atitude } \\
\text { Modalização }\end{array}$ \\
\hline & & & $\begin{array}{l}\text { Organização } \\
\text { Estrutural }\end{array}$ & $\begin{array}{l}\text { Estruturação } \\
\text { verbal }\end{array}$ & $\begin{array}{l}\text { Conexão } \\
\text { Coesão nominal }\end{array}$ \\
\hline
\end{tabular}

Tendo exposto nosso quadro teórico, composto por conceitos e categorias do ISD e categorias de análise da GDV, passemos, agora, para a metodologia que orientou nossa pesquisa. 


\section{CAPÍTULO II - PROCEDIMENTOS METODOLÓGICOS}

Neste capítulo, temos como intuito expor os procedimentos metodológicos para a realização desta pesquisa. Em um primeiro momento, falaremos sobre o contexto e seus participantes; em seguida, abordaremos as etapas para elaboração da pesquisa e descreveremos os procedimentos para a elaboração do modelo didático; após o modelo didático, traremos a sequência didática e algumas considerações sobre a sua elaboração e aplicação; apresentaremos os procedimentos de coleta e produção de dados e, por fim, os procedimentos de análise de dados.

A construção dos procedimentos metodológicos foi guiada por perguntas de pesquisa, que novamente, expomos aqui:

i) Quais são as características do gênero tutorial em vídeo? Quais dessas características podem compor o modelo didático desse gênero para alunos adolescentes?

ii) Qual SD do gênero tutorial pode ser elaborada para alunos adolescentes?

iii) Houve desenvolvimento das capacidades de linguagem dos alunos ao compararmos as produções inicial e final?

iv) Quais indicações o diário de bordo da professora pesquisadora e as conversas gravadas entre alunos durante as aulas podem trazer sobre o processo de produção textual?

\section{Contexto e participantes}

Esta seção foi reservada para a apresentação do nosso contexto de pesquisa. Assim, traremos, primeiramente, a Escola de Aplicação da Faculdade de Educação da Universidade de São Paulo, e em seguida, os participantes: a professora responsável das turmas com as quais trabalhamos; os alunos; a professora-pesquisadora responsável em ministrar as aulas. 


\section{1. Escola de Aplicação da Faculdade de Educação da Universidade de São Paulo}

A pesquisa foi realizada com duas turmas de adolescentes do primeiro ano do Ensino Médio. Os alunos são estudantes da Escola de Aplicação vinculada à Faculdade de Educação da Universidade de São Paulo (doravante EAFEUSP). A Escola de Aplicação ${ }^{8}$ originou-se com uma classe experimental de $1^{\circ}$ ano primário vinculada ao Centro Regional de Pesquisas Educacionais de São Paulo Queiroz Filho (CRPE-SP). Em agosto de 1958, foi constituída a Escola Experimental, que objetivava aperfeiçoar e explorar técnicas de ensino, assim como oferecer aos futuros professores e educadores novas experiências nessa mesma área. No ano de 1973, extinto o CRPE-SP, a Escola vinculou-se à Faculdade de Educação da Universidade de São Paulo e recebeu o nome atual, preservando seu caráter experimental e investigativo. Em 1976, em uma reunião de Congregação, o Prof. Dr. Roque Spencer Maciel de Barros, diretor da Escola de Aplicação na época, substituiu o Conselho Consultivo por um único representante, o Prof. José Mário Pires Azanha (GORDO, 2010). Azanha teve ampla liberdade na reorganização da Escola de Aplicação e um dos seus objetivos foi o de torná-la uma instituição semelhante à escola pública, mas que deveria oferecer um espaço para estágios e pesquisas na área de educação. (GORDO, 2010).

Atualmente, a EAFEUSP conta com turmas de Ensino Fundamental e Ensino Médio. O Ensino Fundamental é dividido em Ensino Fundamental I e Ensino Fundamental II. O primeiro se organiza em dois ciclos, sendo do $1^{\circ}$ ao $3^{\circ}$ ano e do $4^{\circ}$ ao $5^{\circ}$ ano. O Ensino Fundamental II, contempla os 4 últimos anos do Ensino Fundamental e também é dividido em 2 ciclos: do $6^{\circ}$ ao $7^{\circ}$ e do $8^{\circ}$ ao $9^{\circ}$ ano. Por fim, o Ensino Médio contempla os três últimos anos da Educação Básica. As vagas para matrícula são distribuídas por sorteio aos filhos de servidores de Institutos ou Repartições da Universidade de São Paulo e as vagas para o Ensino Médio são automaticamente reservadas aos alunos que concluíram o Ensino Fundamental na instituição (Regimento Escolar EAFEUSP, 2005).

No Ensino Médio, além das disciplinas básicas do ciclo, tais como língua portuguesa, matemática, biologia etc., os alunos cursam as disciplinas de filosofia, sociologia, arte, língua estrangeira moderna e educação física. Nas aulas de educação física, os alunos optam anualmente por uma modalidade (lutas, ginástica, jogos e dança)

\footnotetext{
${ }^{8}$ As informações sobre a Escola de Aplicação da Faculdade de Educação da Universidade de São Paulo foram retiradas do site da Escola. Disponível em: www2.ea.fe.usp.br. Acesso em: 27 Julho 2015.
} 
e as turmas são mescladas entre os três anos do Ensino Médio, de acordo com a demanda de cada modalidade. Nas disciplinas de arte e de língua estrangeira, os alunos têm a possibilidade de optar por uma linguagem artística (teatro, música ou artes plásticas) e uma língua estrangeira moderna (inglês, francês ou espanhol) a serem cursadas durante os três anos de Ensino Médio. As aulas de Língua Estrangeira Moderna têm duração de uma hora e quarenta minutos por semana e as turmas têm, em média, dez alunos. Além das aulas, os professores oferecem semanalmente duas horas de atendimento aos alunos.

\section{2. Os participantes da EAFEUSP}

As turmas com as quais foi trabalhada a sequência didática desta pesquisa têm como responsável pela disciplina de Língua francesa a professora Sahsha Kiyoko Watanabe Dellatorre ${ }^{9}$. Dellatorre possui graduação e licenciatura em Letras PortuguêsFrancês pela Universidade de São Paulo e mestrado na área de Estudos Linguísticos, Literários e Tradutológicos em Francês pela mesma instituição. Ela atua nas turmas de Ensino Fundamental e Médio.

Os alunos participantes estavam no primeiro ano do Ensino Médio, na faixa etária de 15 e 16 anos e, como mencionado anteriormente, são filhos de funcionários das Instituições e repartições da Universidade de São Paulo. No final do Ensino Fundamental, os alunos escolheram a Língua Francesa dentre as opções disponíveis na escola como Língua Estrangeira Moderna e cursarão a disciplina durante os três anos de Ensino Médio. Nesta pesquisa, trabalhamos com duas turmas, sendo que, na primeira, temos dez alunos e na segunda, onze. Em relação ao nível de língua, no Ensino Fundamental II os alunos iniciam seus estudos em Língua Estrangeira Moderna e precisam ter o nível A1 de proficiência (Quadro Comum Europeu de Referência) para continuar o estudo das línguas no Ensino Médio. No entanto, como veremos mais a frente, com a aplicação da sequência didática, vimos que muitos alunos ainda não tinham o nível A1 completo.

\footnotetext{
${ }^{9}$ As informações da professora Dellatorre foram retiradas do lattes da mesma e do site da EAFEUSP.
} 


\subsection{A professora-pesquisadora}

As aulas foram ministradas pela professora-pesquisadora desta pesquisa, e por essa razão, neste momento, o texto será escrito em primeira pessoa do singular.

Sou licenciada em letras com habilitação em português e francês pela Universidade Federal de Viçosa (MG). Fiz pesquisas nas áreas de ensino-aprendizagem de francês como língua estrangeira para crianças através de gêneros textuais específicos e do lúdico. No ano de 2010, tive a oportunidade de trabalhar em um Programa Institucional de Bolsas de Iniciação à Docência (PIBID) de língua portuguesa. O programa tem como intuito proporcionar aos estagiários a experiência de ensino nas escolas públicas e 2011 à 2013, trabalhei no Curso de Extensão em Língua Francesa. Primeiramente, atuei como monitora e em seguida, como estagiária, momento no qual tive a oportunidade de lecionar a língua francesa para a comunidade viçosense.

O ensino-aprendizagem de língua estrangeira sempre me interessou, uma vez que cresci nesse ambiente: de origem japonesa, iniciei meus estudos de língua e cultura japonesa aos três anos e estudei até os quinze anos, idade na qual iniciei meus estudos em língua inglesa. Oriunda de escola pública, meus interesses também permeavam ao ensino nessas instituições e elevaram com a experiência do PIBID. No mestrado então, tenho a oportunidade de articular dois centros de interesse que até então caminhavam separadamente: a didática de línguas e o ensino público.

\section{Etapas da pesquisa}

Com o intuito de alcançar os objetivos desta pesquisa, seguimos as etapas descritas a seguir:

i) Elaboração de um MD do gênero tutorial em vídeos para adolescentes, seguindo: as orientações de Pietro et al. (2013), e nos baseando no quadro da Semiótica Sociointeracional (LEAL, 2011);

ii) Elaboração da SD levando em consideração as dimensões psicológica, cognitiva, social e didática propostas por Schneuwly e Dolz (2013); 
iii) Aplicação da SD. No momento da aplicação, foram feitas gravações em áudio durante o trabalho em grupos, com alguns alunos, para melhor compreender o processo de produção textual dos alunos;

iv) Coleta das produções textuais dos alunos em dois momentos diferentes: produção inicial e final.

v) Análise das produções inicial e final, das gravações da conversa entre os alunos e do diário de bordo da professora.

\section{Os procedimentos para elaboração do modelo didático do gênero tutorial em vídeo}

Para a elaboração do modelo didático do gênero tutorial em vídeos, como ressaltado anteriormente, nos basearemos no quadro de análise proposto por Bronckart (1999). Como já salientado, o quadro de análise textual privilegia os textos verbais e, tendo em vista o fato de o gênero escolhido para esta pesquisa ser um gênero textual multimodal, sentimos a necessidade de uma análise que contemplasse também, os elementos não verbais do texto. Diante disso, nos baseamos no quadro da semiótica Sociointeracional criado por Leal (2011), em que a autora propõe a junção da arquitetura geral dos textos do ISD com as funções da GDV, que podemos ver abaixo: 
Quadro 10: Quadro de análise da Semiótica Sociointeracional

\begin{tabular}{|l|l|l|}
\hline \multicolumn{1}{|c|}{ ISD } & \multicolumn{1}{|c|}{ GDV } & \multicolumn{1}{c|}{ Semiótica Socionteracional } \\
\hline $\begin{array}{l}\text { Infraestrutura } \\
\text { a) Organização temática; } \\
\text { b) Organização discursiva; }\end{array}$ & $\begin{array}{l}\text { Representacional } \\
\text { a) Narrativas; } \\
\text { b) Conceituais; }\end{array}$ & $\begin{array}{l}\text { Organização } \\
\text { representacional: modos de por } \\
\text { os discursos em representações } \\
\text { sociais; } \\
\text { a) Organização Temático não } \\
\text { verbal; } \\
\text { b) Organização temático verbal; }\end{array}$ \\
$\begin{array}{l}\text { Mecanismos de textualização } \\
\text { a) Conexão; } \\
\text { b)Coesão Nominal }\end{array}$ & $\begin{array}{l}\text { Composicional: } \\
\text { a) Valor da informação; } \\
\text { b) Saliência; } \\
\text { c) Estruturação; }\end{array}$ & $\begin{array}{l}\text { Organização estrutural: modos } \\
\text { de configuração dos estruturais: } \\
\text { a) estruturação verbal; } \\
\text { b) Estruturação não-verbal }\end{array}$ \\
\hline $\begin{array}{l}\text { Mecanismos Enunciativos } \\
\text { a) Responsabilidade } \\
\text { enunciativa; } \\
\text { b) Distribuição de vozes; } \\
\text { c) Modalidade/ modalização; }\end{array}$ & $\begin{array}{l}\text { Interativa: } \\
\text { a) Contato; } \\
\text { b) Distância social; } \\
\text { c) Perspectiva; } \\
\text { d) Modalidade; }\end{array}$ & $\begin{array}{l}\text { Organização } \\
\text { modos de manifestação da } \\
\text { interação: } \\
\text { a) Manifestação da interação } \\
\text { pelo verbal; } \\
\text { b) Organização de manifestação } \\
\text { pelo não verbal. }\end{array}$ \\
& & \\
\hline
\end{tabular}

(LEAL, 2011, p. 205)

A seguir, destacaremos os procedimentos utilizados para a elaboração do modelo didático do gênero tutorial em vídeo: apresentaremos os critérios utilizados para a seleção dos tutoriais em vídeos para a sua construção e, em seguida, traremos o nosso modelo didático.

\subsection{Os tutoriais selecionados para a elaboração do modelo didático}

Neste momento, relataremos os critérios da seleção dos vídeos tutoriais utilizados na elaboração do nosso Modelo Didático (MD). Em primeiro lugar, parecenos importante destacar que decidimos utilizar os vídeos disponíveis no site Youtube, por ser um site que permite o compartilhamento de vídeos variados e também porque o site permite vincular suas publicações em outras redes sociais tais como blogs, Facebook etc., isto é, muitos vídeos que estão disponíveis na maioria das redes sociais estão disponíveis também no Youtube. 
Iniciamos a nossa pesquisa com as palavras Tutoriel e Tuto pela barra de busca disponibilizada no próprio site e chegamos a algumas sugestões (tutoriel maquillage, tutoriel coiffure, tutoriel photoshop, tuto cuisine, tuto games etc.). Ao clicarmos em uma dessas sugestões, nos deparamos com uma quantidade bastante significativa de vídeos. Tentamos restringir a quantidade pelos filtros presentes no site, tal como a data em que foi feita a publicação, pela duração, pela contagem de visualizações, avaliação etc.; no entanto, ao tentarmos selecionar pelos vídeos mais bem avaliados ou mais visualizados, por exemplo, nos deparamos, novamente, com uma quantidade significativa de vídeos e alguns que julgamos impróprios para o nosso público, pois continham uma linguagem vulgar, inapropriada para alunos adolescentes. Por esse motivo, adotamos outros critérios para a seleção:

i) selecionamos vídeos de temas variados, alguns que acreditávamos pertencer à dimensão psicológica, ou seja, que são ligadas ao centro de interesse do nosso público, pois assim poderíamos fazer uso posterior na sequência didática;

ii) acrescentamos também, outros de temas não pertencentes a esse centro de interesse, mas com o intuito de verificar se as características do gênero se mantinham;

iii) a partir dos temas, selecionamos vídeos com uma duração de até seis minutos, senão seu uso poderia se tornar cansativo com alunos dessa idade e durante a aula;

iv) por fim, selecionamos os vídeos que julgamos, em uma primeira análise, serem bem estruturados (com cenário, efeitos, luzes), com um caráter mais profissional e outros mais "caseiros", também para observar se as características do gênero se mantinham, mas, sobretudo, para apresentar tutoriais possíveis de serem produzidos pelos alunos. Isto posto, abaixo temos a lista dos tutoriais utilizados na construção do nosso modelo:

1. Le tuto de la semaine: fabriquer une lampe bat-signal (05:45 min);

2. Tutoriel Mode présentateur dans powerpoint 10 (02:42 min);

3. Tuto déco boîte à bonbon (03:32 min) ;

4. Les enfants extraordinaires : Tuto : le cache-œil de Jake (01:54 min) ;

5. Recette facile d'après soirée $n^{o} 6$ : Mug pizza/FastGoodCuisine (04 :52 min) ;

6. Tutoriel - L'attrape rêves (04:41 min);

7. Maquillage simple et naturel en 5 minutes/5 min make up summerlété (06:56 min);

8. Tuto fimo : le minion (4:13 min); 


\section{Cuisine pour les petits - sucettes chamallow chocolat (02:35 min); \\ 10. Une Enceinte "Fait-Maison"! (TUTO) (02: 19 min).}

\section{Modelo Didático do gênero tutorial em vídeo}

Nesta seção, apresentaremos a análise do gênero tutorial em vídeos para a elaboração do Modelo Didático. Ela será apresentada na ordem seguinte:

I) O contexto de produção dos tutoriais em vídeos;

II) Organização temático-representacional, verbal e não verbal;

III) Organização estrutural, verbal e não verbal.

IV) Organização interacional, verbal e não verbal;

\section{I) $O$ contexto de produção dos tutoriais em vídeos}

Como ressaltado anteriormente, para o ISD (Bronckart, 2012), a situação de ação da linguagem inicia-se pelo seu contexto de produção, isto é, pelos parâmetros que podem influenciar na estruturação de um texto. Nos tutoriais em vídeos, o interlocutor ensina como fazer algo a alguém disposto a aprender a fazer alguma coisa. Observarmos que o interlocutor pode ou não ser um especialista: no vídeo tutorial 10, por exemplo, o interlocutor descreve o seu canal como um amante da ciência e de pequenas experiências feitas em casa; no vídeo tutorial 2, por sua vez, podemos observar no perfil do interlocutor que ele é um especialista em apresentações. Em alguns vídeos, observamos que a pessoa que apresenta fala por uma instância maior, ou como definido por Bronckart (2012), por um macro enunciador, podendo ser uma loja de brinquedos, uma página específica de um site etc.

Além disso, como em muitos sites, o Youtube não tem como filtrar se a pessoa realmente existe. Desta forma, muitos enunciadores podem assumir, por exemplo, o papel de um personagem. Não nos delongaremos sobre o assunto, mas há de se salientar que essa possibilidade de anonimato, segundo observou Marcuschi (2005), pode influenciar nas tomadas de decisões em relação à organização textual, nas decisões linguísticas e estilísticas e no próprio conteúdo temático mobilizado no texto, pois o 
interlocutor se encontra livre de muitos julgamentos apresentados em uma interação presencial. Mas, ainda assim, precisaríamos de um estudo mais profundo sobre as novas interações provenientes da internet para poder fazer afirmações mais precisas. Em nossa pesquisa de mestrado, optamos por focalizar em outros aspectos e outros objetivos, como os aspectos multimodais que permeiam o gênero e o processo de desenvolvimento das capacidades de linguagem dos alunos.

Em relação ao receptor dos vídeos, consideramos que são internautas do mundo todo, uma vez que o site permite a visualização de vídeos sem o cadastro, no entanto, acreditamos que eles são destinados à pessoas francófonas, embora seja possível realizar alguns tutoriais em vídeos sem ser falante do francês, já que o gênero se baseia em grande parte nas imagens veiculadas.

Inferimos que os vídeos são destinados à pessoas variadas, mas que são guiados pelo centro de interesse comum dos usuários. Isso pode ser justificado pela própria natureza das redes sociais da internet: são constituídas por pessoas ou organizações interconectadas com o objetivo de compartilhar valores e interesses comuns (SANTIAGO et al, 2014). No canal do emissor do tutorial 1, por exemplo, podemos observar que os vídeos destinam-se à chamada comunidade Geek, que são caracterizados por serem amantes de filmes, séries, vídeo games, história em quadrinhos etc. No do tutorial 6, os vídeos destinam-se à pessoas que querem aprender receitas fáceis e rápidas. Além disso, o destinatário tem a opção de se tornar interlocutor dos vídeos publicados, pois, como dito anteriormente, o site permite um espaço para responder ao produtor, seja com um “curtir", um “descurtir” ou com comentários.

Passando para o local social dos tutoriais em vídeos, como mencionamos nos seus critérios de seleção, os mesmos podem ser encontrados em variados meios de publicação, mas nos restringimos ao site Youtube. Quanto aos objetivos do gênero, além do ensinar algo a alguém, podemos acrescentar também o objetivo de ganhar visibilidade na internet, divulgar um trabalho ou conquistar seguidores. Isso pode ser observado no final de alguns vídeos em que o enunciador convida os usuários do site a reagir ao vídeo: "n’hésitez pas à vous abonner à ma chaîne en cliquant sur le logo et à mettre un puce vert ce le tuto si vous a plu...”, “abonne-toi”. Outro critério que nos fez refletir sobre os novos objetivos por trás do gênero é que sentimos que há uma maior liberdade, por exemplo, na mobilização dos tipos de sequência mobilizados na produção de tutoriais (se pensarmos em tutoriais escritos, em receitas ou manuais de instruções, podemos imaginar que, até então, as sequências estavam restritas à sequências 
descritiva de ações), nos mecanismos enunciativos (tanto nas vozes quanto nos modalizações), nas propriedades estilísticas do texto etc. Discorrermos sobre isso no decorrer da nossa análise.

Voltando aos objetivos, para alcançá-los, o produtor deve fazer uma preparação prévia dos materiais, do que será dito, de como será mostrado e explicar com clareza o procedimento sobre aquilo que ele gostaria de ensinar. Após a gravação do vídeo, ele pode editá-lo e nele acrescentar músicas e efeitos. Em relação ao momento de produção e recepção dos vídeos, podemos dizer que não necessariamente o receptor dos vídeos estão nas mesmas coordenadas do espaço-tempo do produtor do vídeo, mas que é possível pela agilidade com que as informações se propagam na internet. Em cada vídeo, é possível visualizar, também, o momento em que o vídeo foi publicado e não há uma data de expiração. Em alguns vídeos, podemos observar que a publicação é feita com continuidade, como nos exemplos que seguem: "Bienvenus au nouveau tuto..." (Tutorial 1) ou "salut et à la prochaine vidéo" (tutorial 2).

Na tabela abaixo, sintetizamos o que foi discutido sobre o contexto de produção dos vídeos tutoriais:

\begin{tabular}{|c|c|}
\hline CONTEXTO FÍSICO & CONTEXTO SOCIOSSUBJETIVO \\
\hline $\begin{array}{l}\text { Emissor: Um usuário, um grupo de } \\
\text { usuários; um canal de televisão; um } \\
\text { personagem etc. }\end{array}$ & $\begin{array}{l}\text { Enunciador: uma pessoa, não } \\
\text { necessariamente um especialista, que } \\
\text { gostaria de ensinar algo e/ou divulgar um } \\
\text { trabalho, ganhar visibilidade na internet, } \\
\text { conquistar seguidores. }\end{array}$ \\
\hline Receptor: Internau & $\begin{array}{l}\text { Destinatário: Internautas do mundo todo, } \\
\text { falantes da língua francesa e têm a } \\
\text { possibilidade de se tornarem interlocutores. }\end{array}$ \\
\hline $\begin{array}{l}\text { Local físico: Site de compartilhamento de } \\
\text { vídeos Youtube; }\end{array}$ & $\begin{array}{l}\text { Local social: Site de compartilhamento de } \\
\text { vídeos Youtube; }\end{array}$ \\
\hline $\begin{array}{l}\text { Momento: É possível visualizar a data em } \\
\text { que o vídeo foi publicado e não há uma } \\
\text { data de expiração; alguns vídeos são feitos } \\
\text { com certa regularidade; }\end{array}$ & $\begin{array}{l}\text { Objetivo: Ensinar algo a alguém e/ou } \\
\text { divulgar um trabalho, ganhar visibilidade } \\
\text { na internet, conquistar seguidores. }\end{array}$ \\
\hline
\end{tabular}




\section{II) Organização temático-representacional}

Tal como salientado anteriormente com base em Leal (2010), a organização temático-representacional é responsável pelo modo de pôr em discurso as representações sociais expressas no texto e, embora seja possível a interpretação de um texto pelos aspectos verbais e não verbais separadamente (KRESS; VAN LEUWEEN, 2006), percebemos que, no tutorial em vídeos, com exceção dos tutoriais exclusivamente verbais ou não verbais, evidentemente, as imagens muitas vezes são complementares aos aspectos verbais.

O plano geral dos conteúdos temáticos é um exemplo dessa análise conjunta: percebemos que na grande maioria dos tutoriais observados, temos: a) logo do enunciador; b) título do tutorial c) saudação; d) apresentação do que será realizado; e) materiais utilizados; f) modo de fazer; g) resultado final; h) agradecimento e/ou convite para seguir a página ou o usuário do produtor do vídeo; i) despedida. No entanto, acreditamos que, por ser um gênero que circula em um meio mais "informal", sentimos que os interlocutores possuem mais liberdade na mobilização dos conteúdos: podemos observar, por exemplo, momentos em que há uma justificativa da realização do vídeo, a função daquilo que está sendo ensinado, a apreciação do enunciador sobre o que será ensinado, um comentário sobre o que foi feito e o motivo de se fazer de uma determinada forma. Isso retoma, novamente, o que havíamos comentado sobre o objetivo que não se restringe ao ensinar algo à alguém, mas convencer o interlocutor a realizar o vídeo ou mostrar que ele é interessante (exemplo: c'est facile, rapide et pas cher!).

Quanto às sequências mobilizadas, o tutorial organiza-se predominantemente em uma longa sequência dialogal. Além disso, por se tratar de tutoriais em vídeo que, de certa forma, concorrem com outros pelo número de visualizações e que contribuem para que seu autor se torne conhecido na web, pudemos observar uma forte tendência à argumentação, para que os interlocutores assistam seu tutorial e, para tanto, quer convencê-los de que ele é interessante. Nesse sentido, encontramos um efeito argumentativo global veiculado pelos tutoriais, semelhante ao encontrado por Melão (2014) em anúncios publicitários. Sem que apresentem sequências argumentativas completas, esses gêneros parecem se apoiar em aspectos multimodais para criar um efeito argumentativo global que visa a convencer os interlocutores. 
Além das sequências acima, observamos sequências injuntivas em que segundo Bronckart "o agente produtor visa a fazer agir o destinatário de um modo ou em uma determinada ação" (2007, p. 237).

Quanto ao mundo discursivo, na grande parte dos tutoriais em vídeos observados, o tipo do discurso é o do expor implicado: podemos dizer que eles estão estritamente ligados ao mundo ordinário (conjunto) e a implicação pode ser verificada através de dêiticos de pessoas e espaciais e o uso de verbos no presente do indicativo ("vous cliquez" "vous soulignez" - Tutorial 2), no imperativo ("Découpez...", "Faites..." - Tutorial 10) e no futuro ("on va commencer par..." "On va découper...". Assim, podemos dizer que o tutorial caracteriza-se por se organizar em discurso interativo.

$\mathrm{Na}$ organização temático-representacional não verbal, por seu turno, encontramos as representações narrativas e conceituais.

Nas representações conceituais, segundo Kress e Van Leeuwen (2007), não há uma ação entre os participantes ou objetos representados e, por essa razão, elas são caracterizadas pela ausência de vetores. Dentre os tutoriais analisados, observamos que as representações conceituais aparecem quando se quer dar ênfase ao que será ensinado (isso pode ser verificado pelo tamanho exagerado) ou a um objeto simbólico, como observaremos no exemplo abaixo:

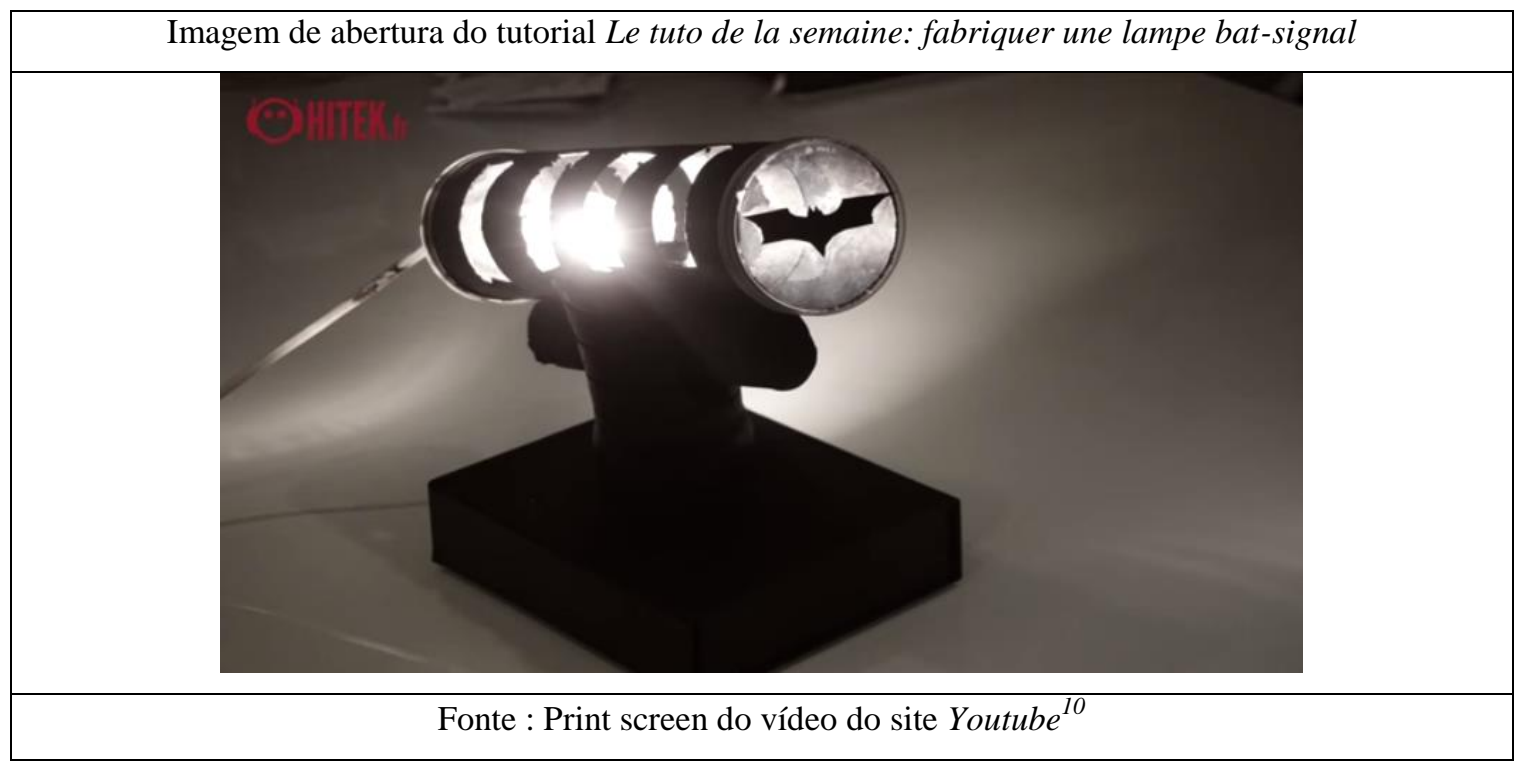

${ }^{10}$ Disponível em: <www.youtube.com/watch?v=2myf09YEwg0>. Acesso em 28 jul 2015. 
Tivemos uma recorrência de representações conceituais como a exposta acima, no início do tutorial e quando se quer dar ênfase em um objeto. Quanto a sua aparição ao início, se fizermos uma relação com um texto exclusivamente verbal, poderíamos dizer que se trata do título do texto.

O exemplo abaixo é uma representação conceitual que traz um objeto simbólico: o $\log 0$ do usuário. Apesar do logo ser bastante significativo, pois ele pode trazer significados e marcas das representações culturais, nos restringiremos à análise de que se quer dar ênfase ao produtor do texto. Isso confirma a nossa ideia da auto promoção por traz dos objetivos do gênero. Percebemos a recorrência desse tipo de representação conceitual algumas vezes no início do vídeo, no final ou em ambos.

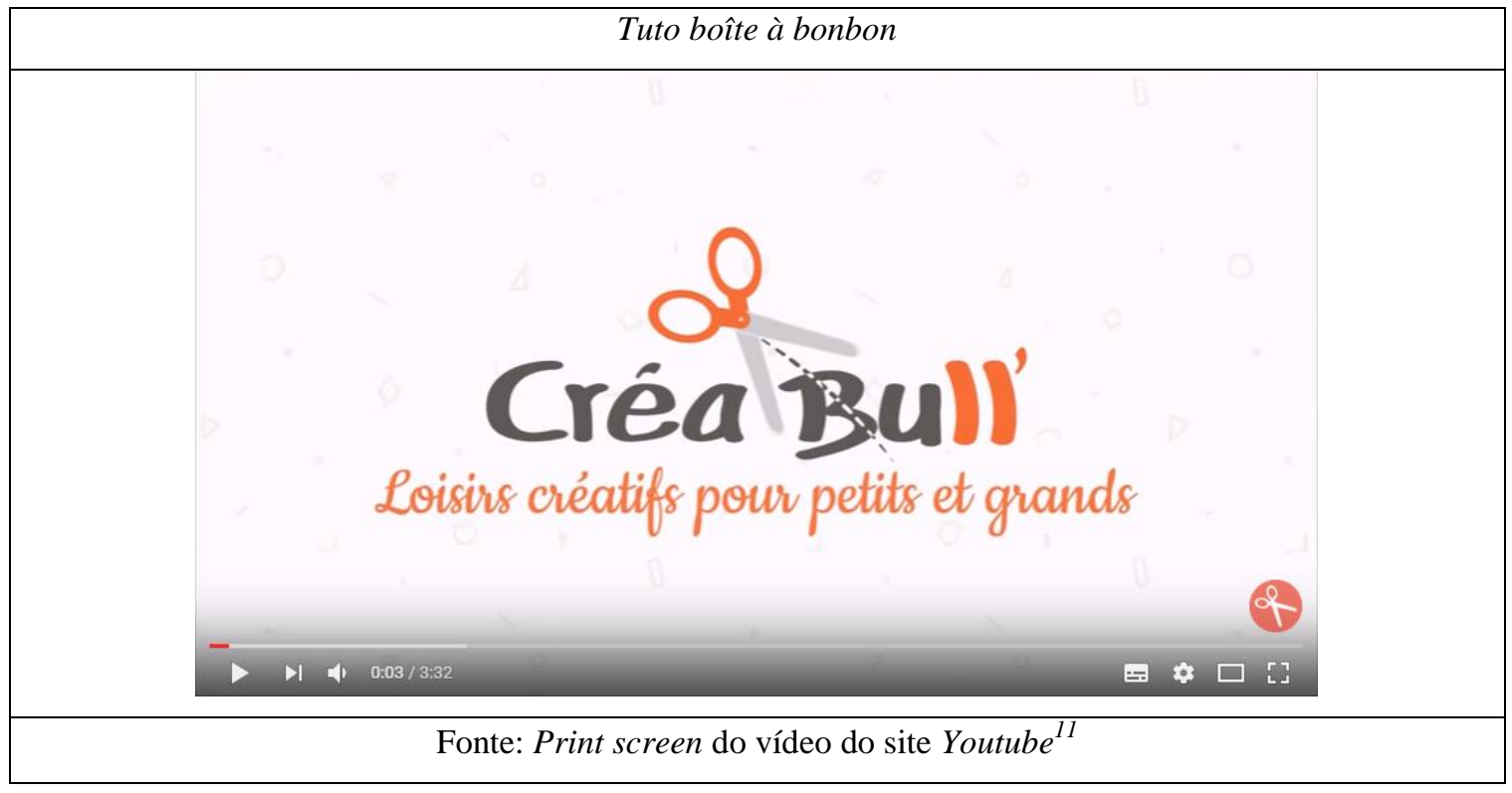

As representações narrativas, segundo Kress e Van Leeuwen (2006), são identificadas por meio de setas e essas, por sua vez, indicam existir um participante que volta sua ação para outro. Nos tutoriais em vídeos selecionados, encontramos o processo de reação não-transacional, processos de ação transacional e de ação nãotransacional.

Pouco recorrente, no exemplo abaixo, temos uma narrativa de reação transacional. Nele, podemos observar o vetor por meio do olhar de um dos participantes representados para outro e esta imagem complementa a sequência narrativa em que o produtor cria uma "treatralização" no ato comunicativo.

\footnotetext{
${ }^{11}$ Disponível em: 〈https://www.youtube.com/watch?v=7E9 ipHcJcE〉. Acesso em 28 jul 2015.
} 


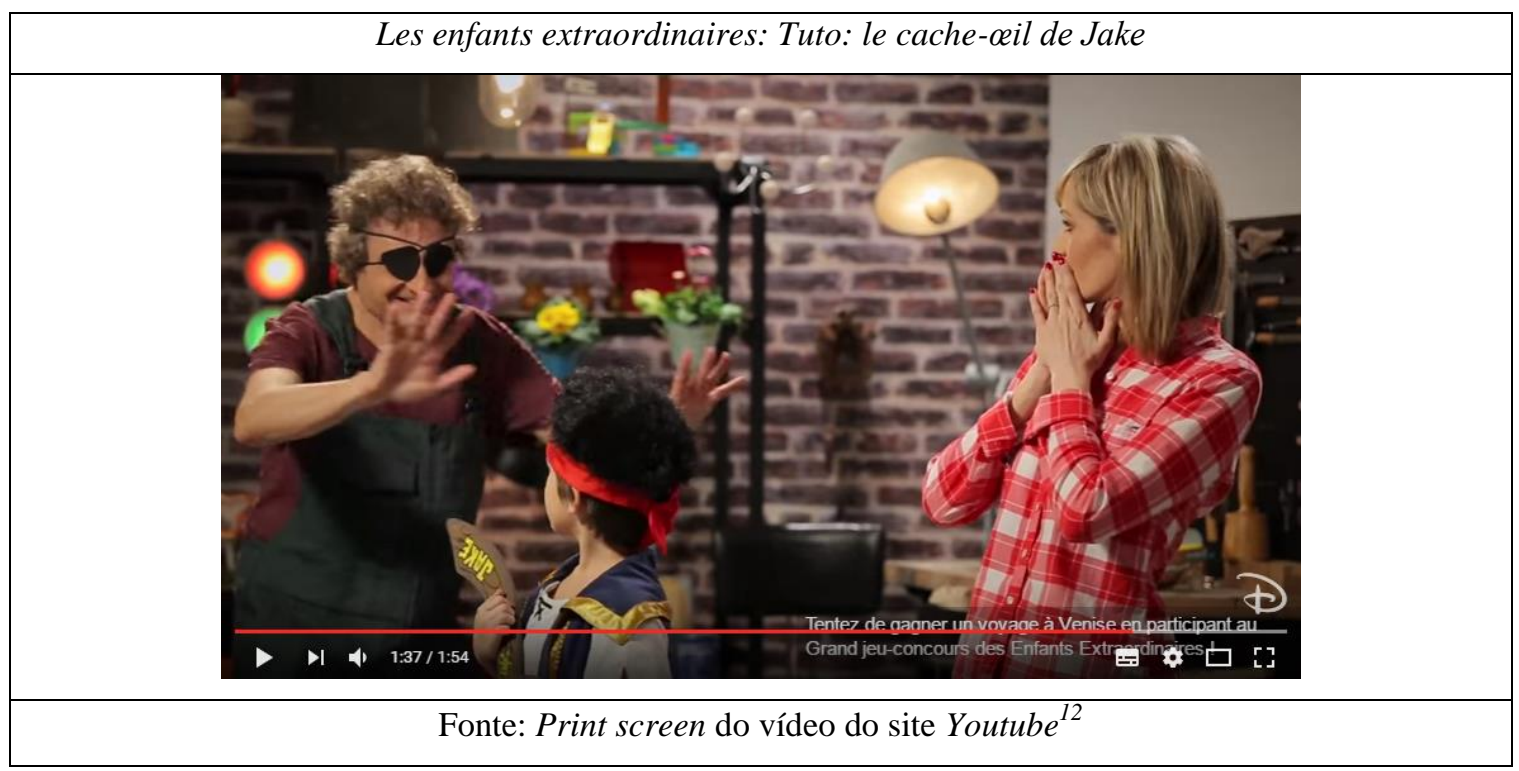

Na figura 5, recorrente nos tutoriais observados, temos o processo de reação, pois esse processo é caracterizado pela presença de vetor através do olhar do participante representado. Assim, como podemos observar no texto verbal, através do olhar, há implicação do leitor no texto, convidando-o a participar da cena comunicativa. No entanto, como o leitor, evidentemente, não aparece na imagem, ela é classificada como não transacional.

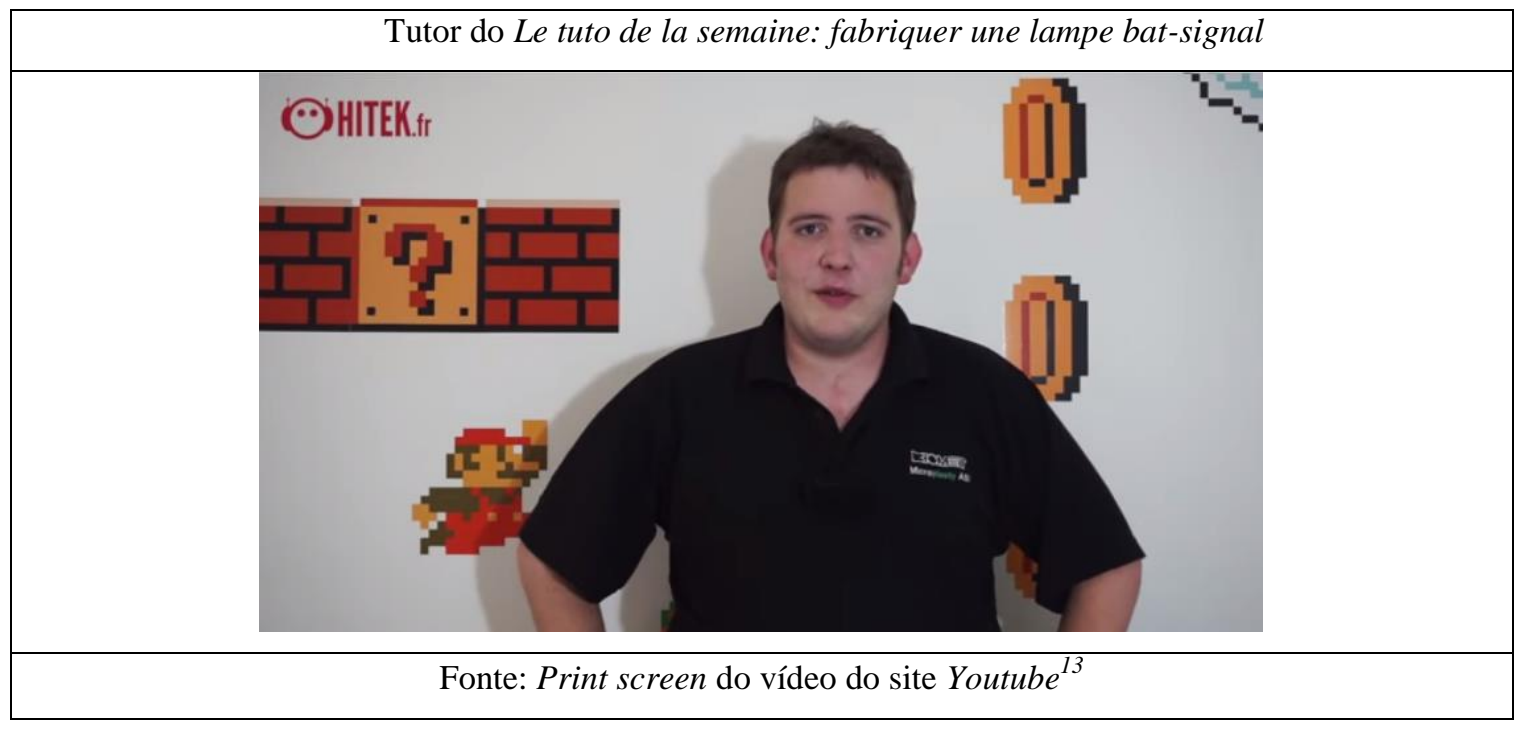

No exemplo que segue, comum nas imagens em que o produtor mostra os materiais necessários ou o modo de fazer, o vetor não é transmitido pelo olhar, mas pela

\footnotetext{
12 Disponível em: < https://www.youtube.com/watch? $v=d n V 4 L n D c L 4 E>$. Acesso em 28 jul 2015.

${ }^{13}$ Disponível em: <www.youtube.com/watch?v=2myf09YEwg0>. Acesso em 28 jul 2015.
} 
ação mostrada na imagem e, por essa razão, classificamos como narrativa de ação. Nessa imagem, não conseguimos identificar o participante representado, apenas parte dele. Sendo assim, esta é uma representação narrativa de ação não transacional: nela conseguimos perceber a meta (o objeto que recebe a ação) e o processo (a ação do participante representado). Elas foram recorrentes nos momentos em que o participante em cena apresenta os materiais necessários e no modo de fazer.

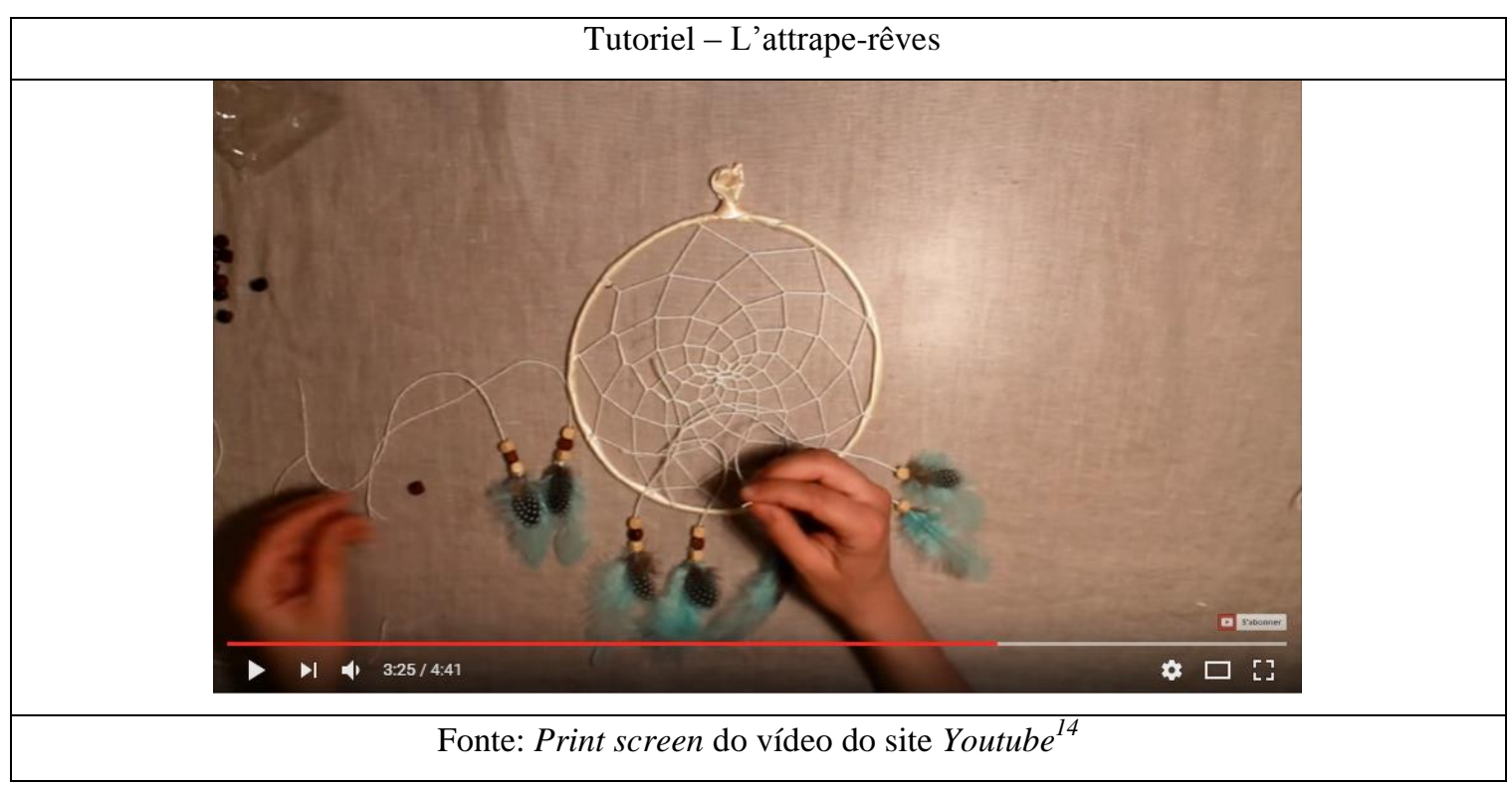

\section{Organização estrutural}

O segundo nível de organização proposto em nossa análise é a organização estrutural, que se refere ao modo como o texto é apresentado em sua composição. Na organização estrutural verbal, encontramos variados mecanismos de textualização que auxiliam na progressão dos conteúdos temáticos. Quanto à coesão nominal, tivemos a recorrência de uso de demonstrativos "comme ceux-ci", "cette lampe", "Vous devez. vous retrouver un résultat à peu près équivalent à celui-ci”" e as referências catafóricas como em "prenez-la", "tu la prennes" etc.

Ainda no que diz respeito à coesão nominal, os artigos partitivos, por exemplo, foram utilizados, principalmente, em tutoriais de cozinha, mas também encontramos quando o enunciador apresenta os materiais necessários, como por exemplo "on $a d u$

\footnotetext{
${ }^{14}$ Disponível em: <https://www.youtube.com/watch?v=yl9EwKKuK8E>. Acesso em 28 jul 2015.
} 
carton, de la colle...". Quando não utilizados os partitivos, o enunciador fornecia a quantidade/tamanho exato dos materiais: "une cuillère à soupe de...", "vous allez avoir besoin d'une lampe" etc.

Na coesão verbal, tivemos a ocorrência de verbos no Presente do indicativo, no imperativo, no futuro próximo, no futuro simples, no infinitivo e no passado composto. Por ser um texto em que as marcas da oralidade são recorrentes, percebemos uma alternância dos tempos e dos modos verbais. Também percebemos as marcas de temporalidade como "aujourd'hui", "la semaine dernière", "bienvenue à un nouveau tuto", "maintenant", "cette semaine" etc.

Em relação à conexão, encontramos organizadores cronológicos ( "d'abord", "prémièrement”, "ensuite”, "pour finir" "et”) e marcas da oralidade ("et voilà", "alors", "donc", "en fait", "bon").

Quanto ao valor da informação, tivemos tanto imagens em que os participantes estão de forma centrada como não polarizada. As imagens centradas foram muito recorrentes em imagens com o participante representado em cena, com o que seria ensinado ou com o nome do canal. Abaixo, temos um exemplo de valor centrado em que o canal do enunciador é o foco da imagem. Nesse mesmo exemplo, podemos perceber a presença de emolduramento que influencia na construção da cena comunicativa, assim como na imagem que o produtor gostaria de passar sobre o seu canal:

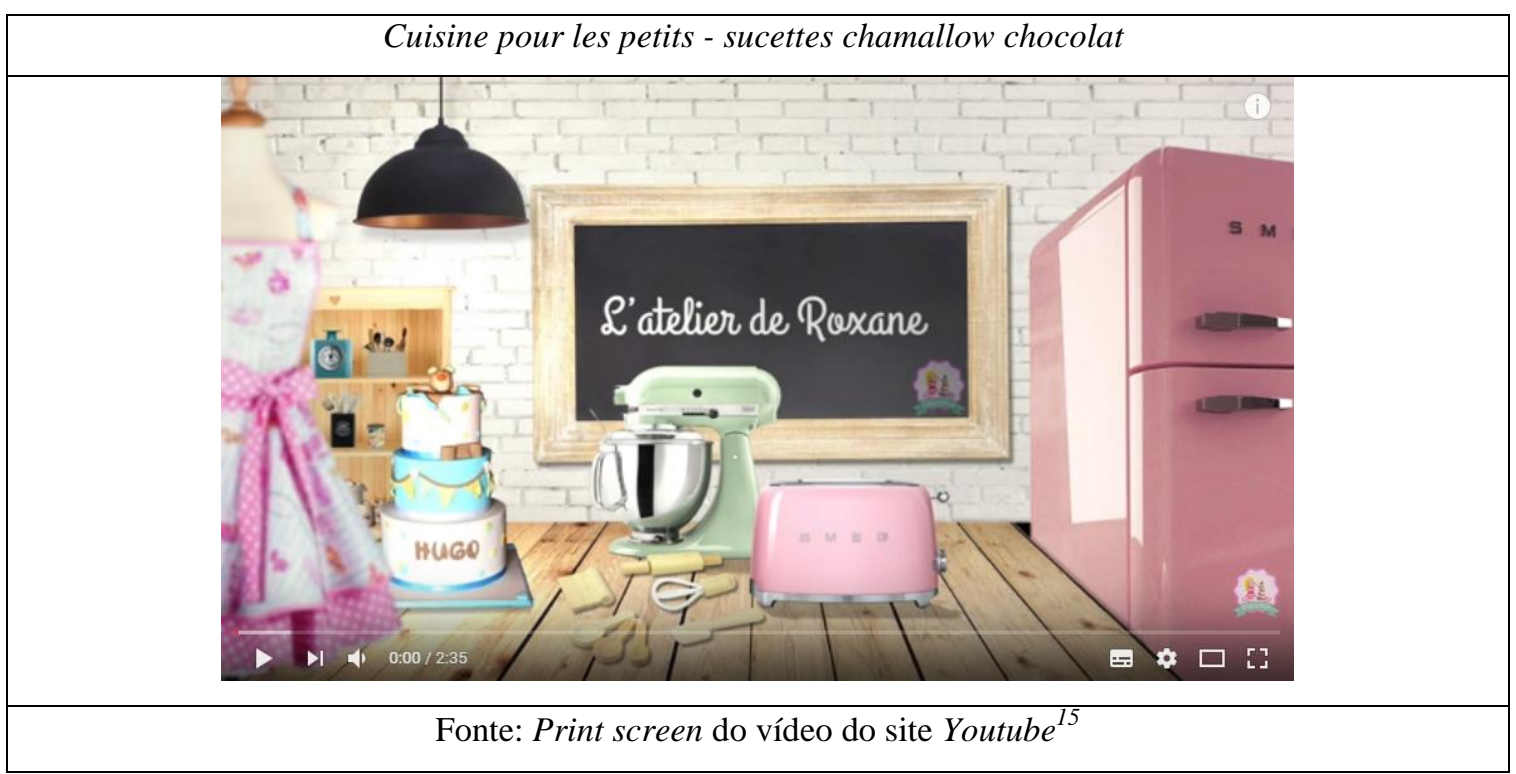

\footnotetext{
${ }^{15}$ Disponível em: www.youtube.com/watch?v=2myf09YEwg0. Acesso em 28 jul 2015.
} 
O exemplo abaixo, por outro lado, traz um exemplo de informação polarizada. Nesse caso, as informações são dispostas sem se dar ênfase a um objeto em específico, pois não há um grau de importância entre os elementos presentes no texto.

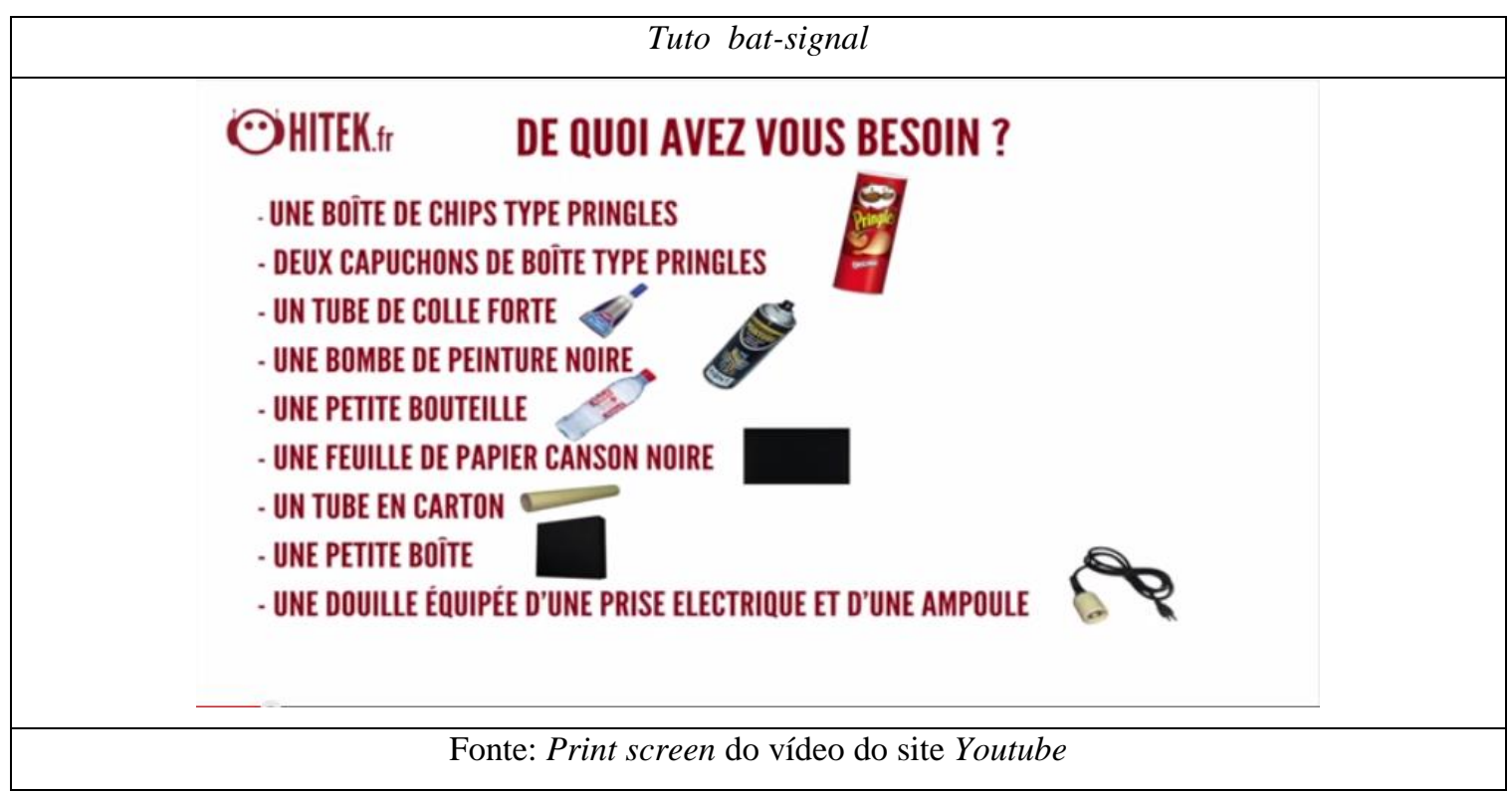

Apesar do quadro da Semiótica Sociointeracional ser restrito à análise dos aspectos verbais e das imagens presentes no texto, percebemos, por exemplo, que alguns efeitos presentes nos vídeos também podem ser interpretados segundo as categorias propostas. Nos vídeos observados, encontramos variados efeitos que consideramos como estilísticos ou que são complementares, seja à imagem ou ao texto verbal (as onomatopeias e músicas, por exemplo). Observamos também alguns efeitos de corte e aceleração da imagem, que têm uma função diminuir o tamanho do vídeo. Nesses casos, acreditamos que os efeitos funcionariam como um mecanismo de textualização, pois eles auxiliam na progressão dos conteúdos temáticos e na organização textual.

\section{III) Organização interacional}

A terceira categoria de nossa análise se refere aos modos de manifestar a interação, divididos por Leal (2010) em três aspectos: relação entre autor e leitor, entre 
os elementos semiotizados no texto e entre os participantes representados e os participantes interativos.

Iniciando pelos níveis de responsabilidade enunciativa do texto, com a ressalva de que nos posicionamos na concepção de que um texto é constantemente atravessado por vozes, que podem variar o grau de explicitação em menor ou maior grau de ocultamento (segundo o conceito bakthiniano de dialogismo), observamos as vozes do enunciador; do leitor; de personagens presentes na cena comunicativa (com uma voz explícita, marcada por dêiticos de pessoas); vozes de grupos sociais ou voz de uma cantiga para crianças e de filmes (com um menor grau de explicitação).

O trecho do vídeo tutorial 7, por exemplo, nos mostra um exemplo de voz implícita (BRONCKART, 2011) de grupos sociais, mais especificamente, o grupo social jovem. Nesse trecho, o pronome pessoal "vous" traz a voz do interlocutor que, nesse caso, podemos interpretar como a voz do grupo ao qual ele destina o vídeo: "vous avez toujours fai::m... vous avez envie de l'autre chose que des pâtes que vos amis vous proposent éternellemment...". Nossa compreensão se baseia nos vídeos publicados pelo enunciador: predomínio de uma linguagem dos jovens; temáticas que ficam em torno de comidas fáceis e rápidas; estilo dos vídeos.

Observamos, também, casos de vozes variadas que são chamadas para o texto de forma implícita (BRONCKART, 2011) para criar uma identificação com o público e para causar um efeito humorístico. É o caso do tutorial 5, em que identificamos duas inserções de vozes: 1 . a voz de Jack Sparrow ${ }^{16}$, já que um dos autores aparece vestido como ele ao dirigir-se a crianças, ou seja, ao público infantil (nesse caso, consideramos que é um índice multimodal de inserção de vozes); 2. a presença de uma cantiga infantil (“je vais vous apprendre aujourd'hui à planter des choux à la mode de chez nous...” ), que também contribui para a identificação com o público. Nesse caso, é o fato de que se trata de "palavras de outro lugar" (uma "comptine" para crianças), segundo AuthierRevuz (2002), que permite identificar a inserção de vozes. Nesse segmento, um dos personagens inicia o vídeo dizendo que o tema seria relacionado à jardinagem e faz alusão à cantiga. Em seguida, outro personagem entra em cena anunciando o verdadeiro tema do dia: o tapa olhos do personagem Jack Sparrow. Assim, podemos observar o efeito humorístico causado na construção textual que mistura o personagem a essa cantiga.

\footnotetext{
${ }^{16}$ Personagem do filme Piratas do Caribe.
} 
Como salientamos mais acima, encontramos vozes nos aspectos multimodais do texto e nomeamos como índices não verbais de inserção de vozes: esses índices não verbais de inserção de vozes foram observados em músicas (nos tutoriais 1 e 7 , temos as trilhas sonoras dos filmes Batman e Piratas do Caribe, respectivamente), nas vestimentas dos enunciadores ou personagens que remetem a algum filme (por exemplo, Jack Sparrow) ou a algum estereótipo, no cenário e objetos presentes em cena. Esse índice não verbal de inserção de vozes pareceu-nos bastante apropriado para a análise de textos multimodais.

No que se refere às modalizações, percebemos que, para descrever o processo de preparação/elaboração ou os materiais necessários, foram utilizadas as modalizações deônticas como: "Il nous faut", "il va vous falloir", "vous devez..." que equivalem ao uso do imperativo. Observamos, também, que em muitos tutoriais há constatações de certeza, por meio de modalizações lógicas "Vous avez toujours faim, vous avez envie de manger autre chose que les pâtes que vos amis vous proposent..." (Tutorial 11), "Et oui, j'ai bien dit, une pizza au moins de 5 minutes!" Acreditamos que essas modalizações aparecem para persuadir o interlocutor de que o tutorial é interessante de se fazer. Para finalizar as modalizações, foram encontradas as apreciativas que se referem ao que será ensinado: "Vous allez voir des astuces rapides, faciles et pas cher" (tutorial 12), "aujou

rd'hui je vous montre une recette exceptionnelle..." (tutorial 11).

Segundo Kress e Van Leeuwen (2006), a manifestação da interação pelo não verbal pode ser verificada a partir de três recursos da linguagem: o contato, a distância social e a atitude. No contato, que pode ser classificado como de interpelação e de exposição, encontramos ambos os casos: 


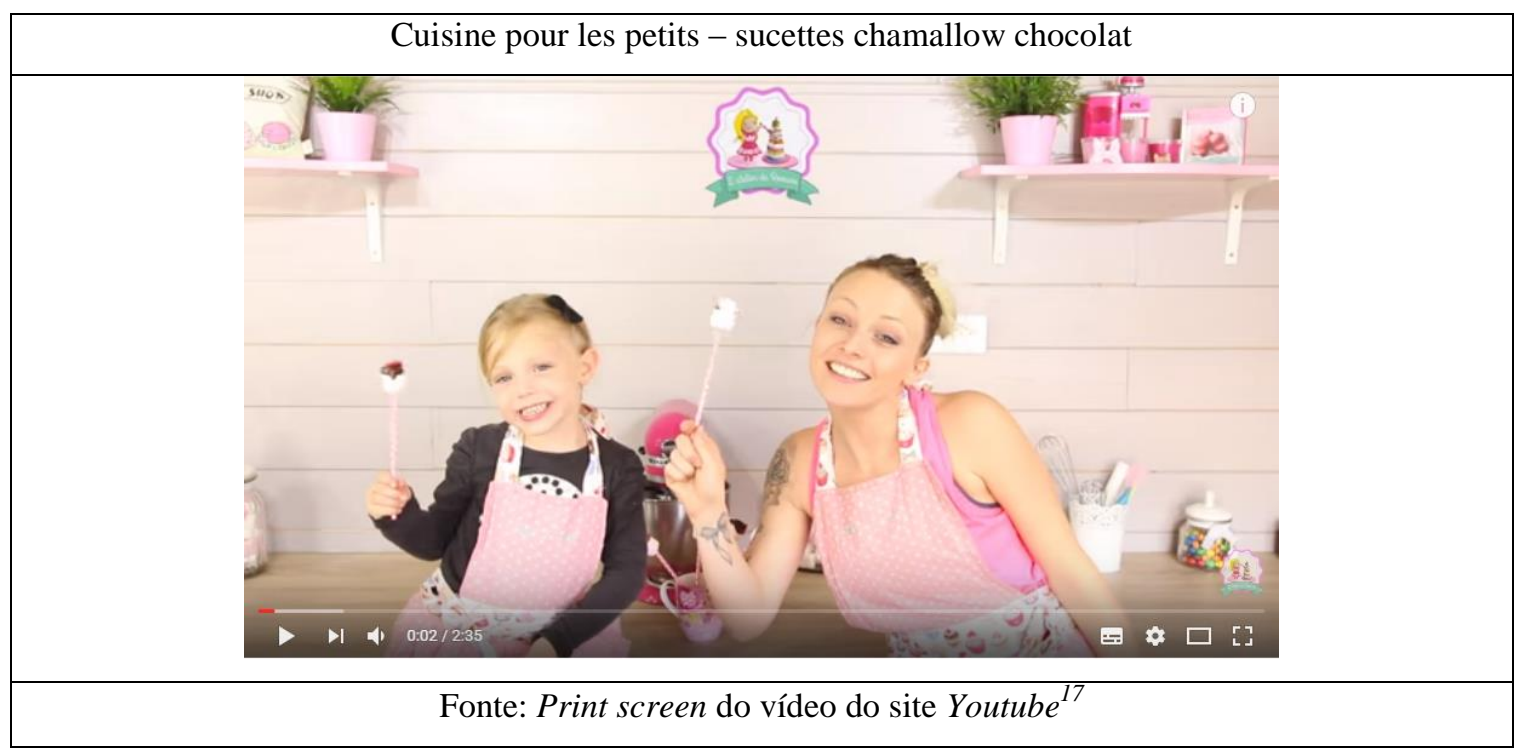

Nesse exemplo, podemos dizer que é um contato de interpelação, uma vez que o participante representado olha para o leitor da imagem. Dessa forma, ainda que imaginária, estabelece-se uma ligação em que o leitor é convidado a participar do ato semiótico. $\mathrm{Na}$ imagem que segue, temos um contato de exposição. Nesse tipo de imagem, o participante não estabelece uma ligação pelo olhar, mas é observado pelo leitor da imagem.

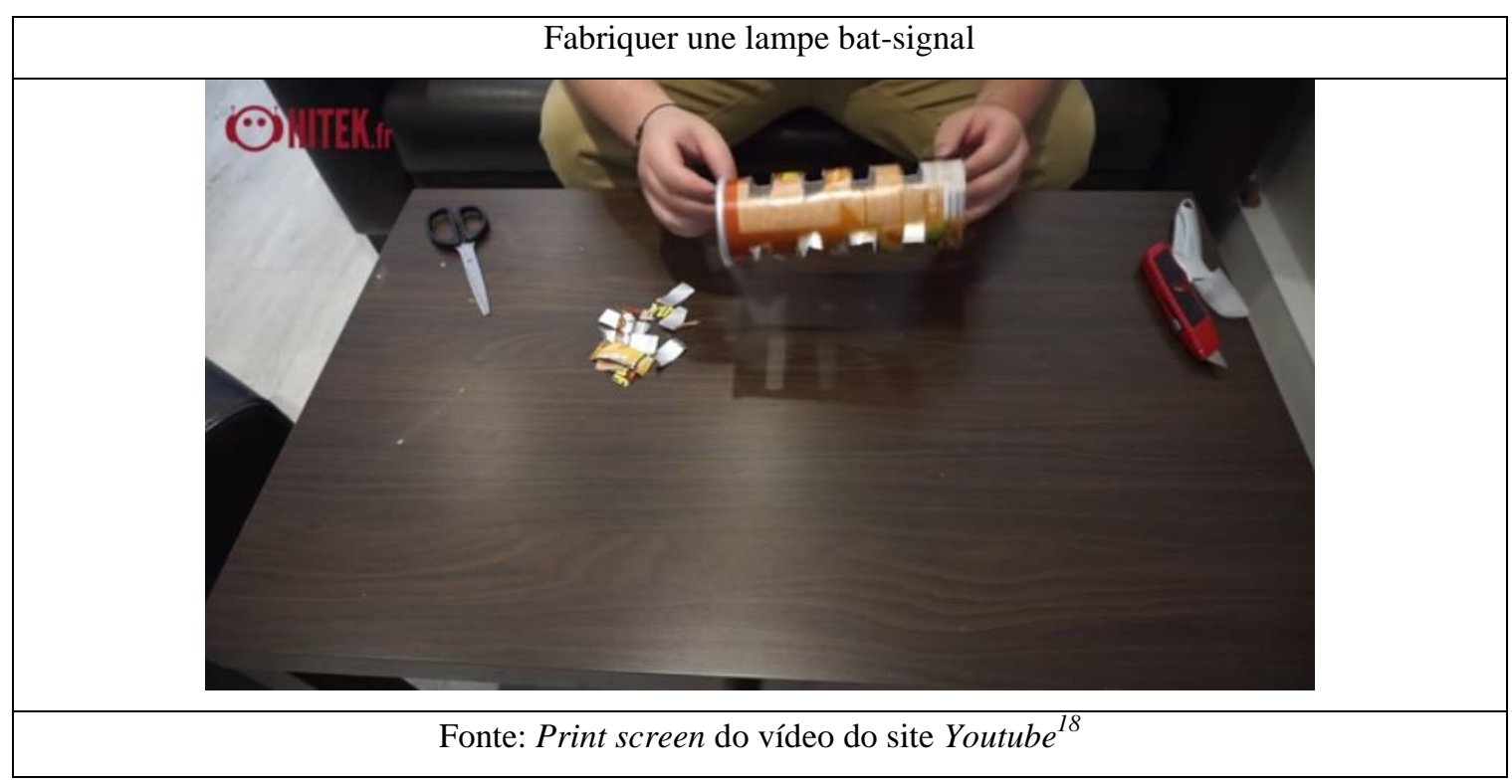

${ }^{17}$ Disponível em: www.youtube.com/watch?v=jrdYgY-UiCM. Acesso em 28 jul 2015.

${ }^{18}$ Disponível em: www.youtube.com/watch?v=2myf09YEwg0. Acesso em 28 jul 2015. 
Quanto à categoria distância social, que revela a intimidade entre o participante representado e o leitor, dividida em plano fechado, plano médio e plano geral, observamos uma recorrência do plano fechado, onde há uma aproximação afetiva e demostra um grau de intimidade entre o enunciador e o leitor da imagem, como o exemplo a seguir:

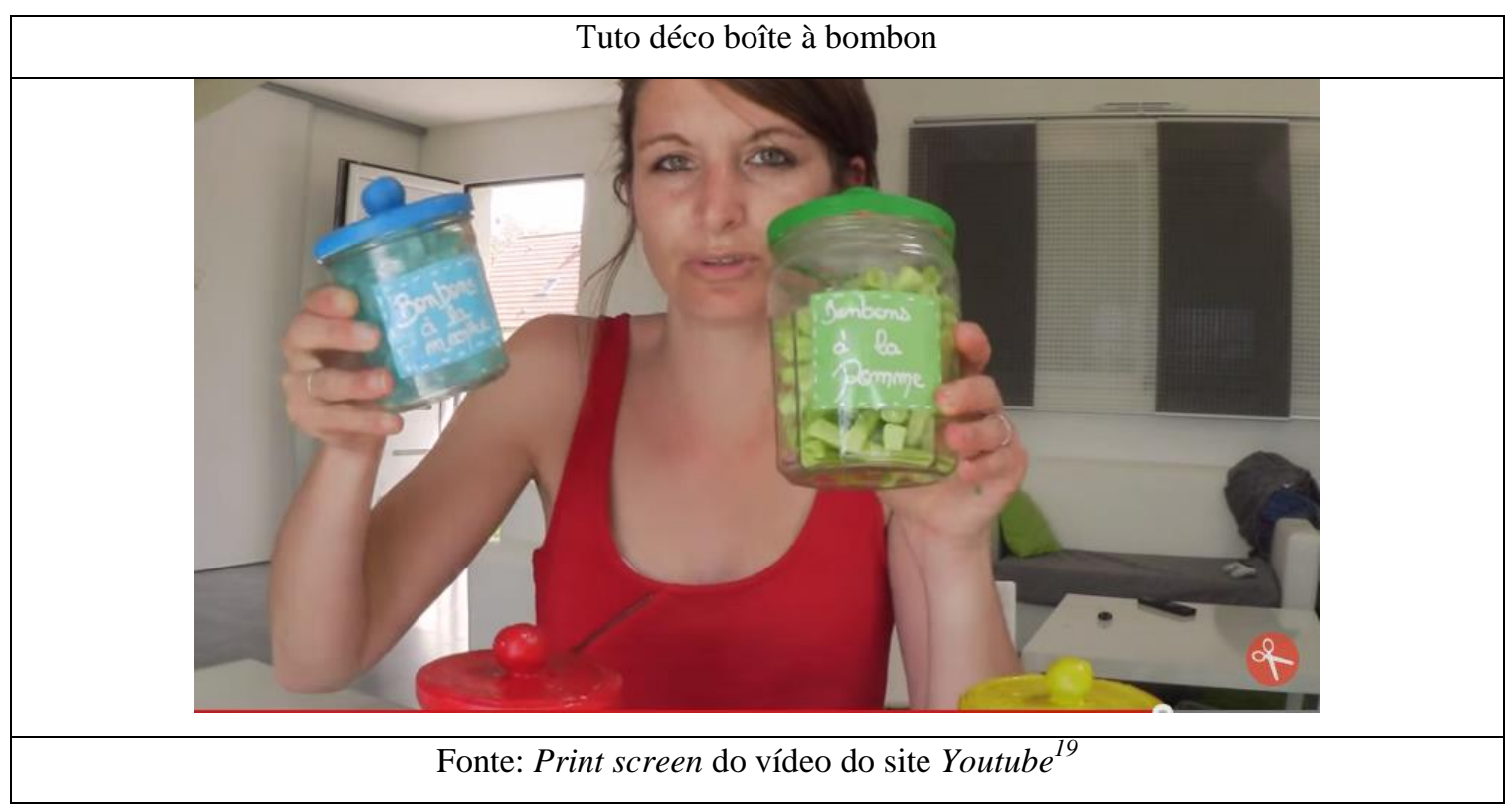

$\mathrm{Na}$ categoria atitude, que seria a perspectiva na qual se encontra o participante representado, encontramos predominantemente exemplos de atitude subjetiva (ângulo frontal) no qual o participante representado se demonstra um grau de envolvimento com o interlocutor. Esse ângulo indica uma aproximação e igualdade entre o interlocutor e o locutor.

Para Kress e Van Leeuwen (2006), a modalidade é associada à confiabilidade das mensagens. Em outras palavras, é a partir dela que o sujeito-enunciador acredita ser verdadeiro ou falso. Em relação à contextualização, tivemos tutoriais "mais caseiros", onde não há uma preocupação com o cenário, e mais detalhados, tais como nos exemplos a seguir:

\footnotetext{
${ }^{19}$ Disponível em: www.youtube.com/watch?v=7E9_ipHcJcE. Acesso em 28 jul 2015.
} 

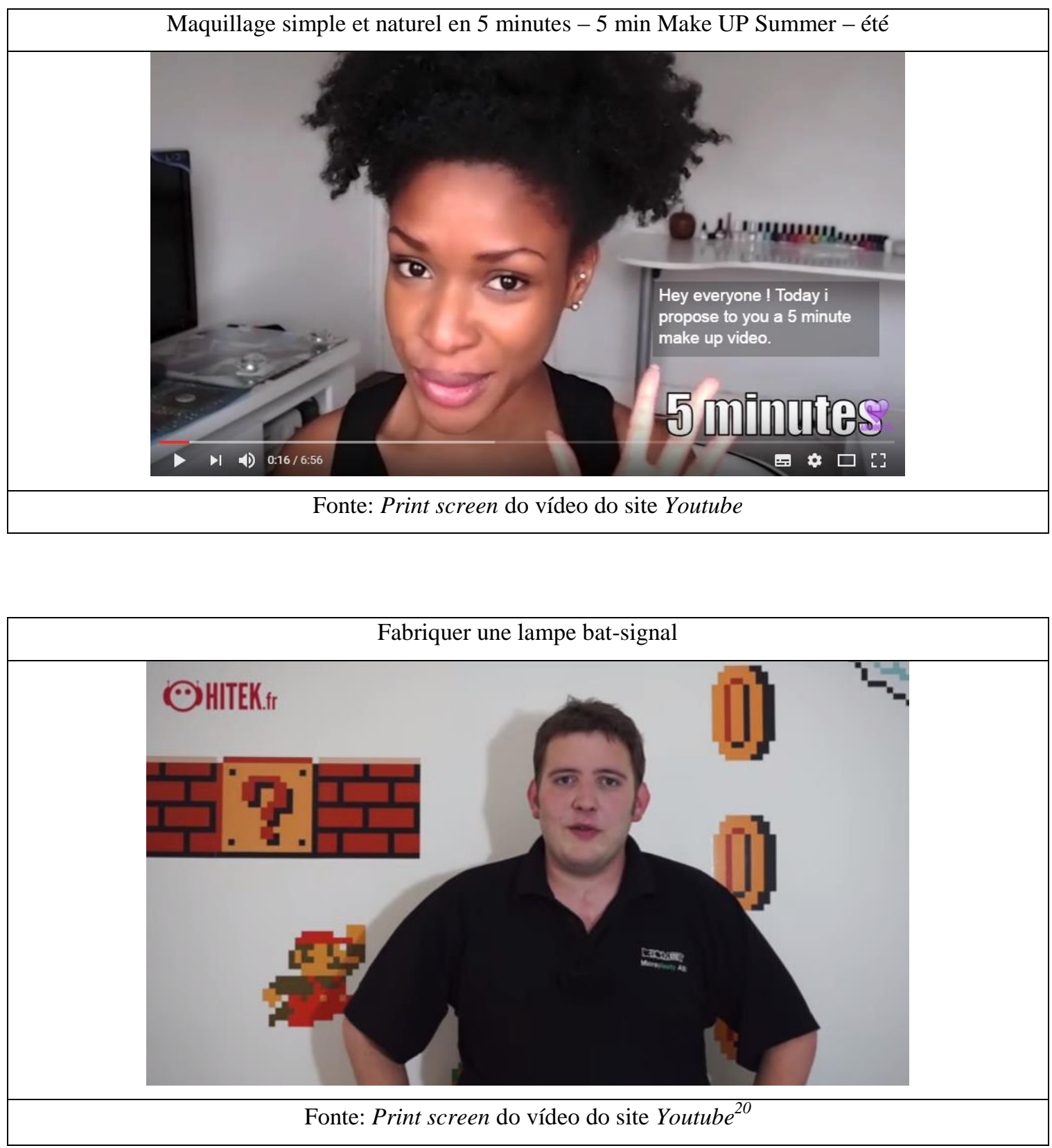

No exemplo acima, podemos perceber que o cenário, ainda que não seja o foco do tutorial, auxilia na imagem de si que o enunciador quer transmitir e tem relação com os índices de inserções de vozes não verbais mencionados anteriormente. Temos neste cenário referência a jogos de vídeo game e ele dialoga justamente com o público alvo do canal em que se é encontrado o vídeo: amantes de filmes, séries, jogos eletrônicos, ou os chamados Geeks.

\footnotetext{
${ }^{20}$ Disponível em: www.youtube.com/watch?v=2myf09YEwg0. Acesso em 28 jul 2015.
} 
Uma vez apresentadas as características principais dos tutoriais em vídeo que deram origem ao nosso Modelo Didático, gostaríamos de salientar que o nosso objetivo não é esgotar todas as formas verbais e não verbais encontradas no texto, uma vez que os tutoriais em vídeos apresentam algumas diferenças de estruturação. Além disso, como destacado anteriormente, o modelo didático não é trabalhado com alunos tal qual o estudamos e apresentamos. Através dele, retiramos as dimensões ensináveis para a posterior elaboração da sequência didática e nem sempre é possível trabalhar todos os aspectos elencados, principalmente quando consideramos os alunos para quem a SD foi elaborada.

Diante do que expusemos, elaboramos um quadro síntese do modelo didático do gênero tutorial em vídeos:

\begin{tabular}{|l|l|}
\hline \multicolumn{2}{|c|}{ Contexto de produção } \\
\hline Enunciador & $\begin{array}{l}\text { Alguém, não necessariamente um especialista, que gostaria de ensinar algo e/ou ganhar } \\
\text { visibilidade na internet; }\end{array}$ \\
\hline Destinatário & $\begin{array}{l}\text { Internautas do mundo todo falantes da língua francesa tendo a possibilidade de se tornar } \\
\text { interlocutor. }\end{array}$ \\
\hline Lugar social & Sites de compartilhamento de vídeos Youtube. \\
\hline Objetivo & Ensinar algo a alguém, ganhar visibilidade na internet, conquistar seguidores. \\
\hline
\end{tabular}




\begin{tabular}{|c|c|}
\hline \multicolumn{2}{|r|}{ Organização temático-representacional } \\
\hline $\begin{array}{l}\text { Plano global } \\
\text { dos conteúdos } \\
\text { temáticos }\end{array}$ & $\begin{array}{l}\text { a) logo } \\
\text { a) Título do tutorial; } \\
\text { b) saudação; } \\
\text { c) apresentação do que será realizado; } \\
\text { - Possibilidade de justificativa da realização do vídeo, função daquilo que está sendo } \\
\text { ensinado, apreciação do enunciador sobre o que será ensinado; } \\
\text { d) materiais utilizados; } \\
\text { e) modo de fazer; } \\
\text { f) resultado final; } \\
\text { - Possibilidade de comentário do enunciador em relação ao vídeo; } \\
\text { g) agradecimentos e convite para "curtir" e seguir o enunciador. } \\
\text { h) despedida. }\end{array}$ \\
\hline $\begin{array}{ll}\text { Tipos } & \text { de } \\
\text { discurso } & \end{array}$ & $\begin{array}{l}\text { Discurso interativo (expor implicado) pois os vídeos tutoriais são ligados ao mundo } \\
\text { ordinário e apresentam implicação através de dêiticos de pessoas, espaciais e } \\
\text { temporais. }\end{array}$ \\
\hline $\begin{array}{ll}\text { Tipos de } \\
\text { sequência }\end{array}$ & $\begin{array}{l}\text { Presença de uma macro sequência dialogal; } \\
\text { Sequência descritiva de ações que encontramos, por exemplo, em uma receita ou um } \\
\text { manual de instruções; } \\
\text { Possibilidade de efeito argumentativo global sem que apresentem sequências } \\
\text { argumentativas completas. }\end{array}$ \\
\hline $\begin{array}{l}\text { Tipos de } \\
\text { representações }\end{array}$ & $\begin{array}{l}\text { Representações narrativas: quando há uma ação na cena comunicativa. } \\
\text { a) de reação: quando o participante da cena volta o olhar para outro (pouco recorrente); } \\
\text { b) de ação: o participante age sobre determinada pessoa ou objeto; } \\
\text { Representações conceituais: inexistência de ação entre os participantes ou objetos na } \\
\text { cena comunicativa, normalmente apresentados por um objeto simbólico ou quando se } \\
\text { quer dar ênfase no objeto a ser ensinado. }\end{array}$ \\
\hline
\end{tabular}

\begin{tabular}{|l|l|}
\hline \multicolumn{2}{|c|}{ Organização interacional } \\
\hline $\begin{array}{l}\text { Valor } \\
\text { informação }\end{array}$ & Centrada e não polarizada. \\
\hline Conexão & D'abord, prémièrement, ensuite, pour finir, après, finalement, etc. voilà, alors. \\
\hline Coesão & $\begin{array}{l}\text { a) Nominal: demonstrativos, catáforas, anáforas, partitivos/quantidade medida exata. } \\
\text { b) Verbal: predomínio do imperativo, mas encontramos também o infinitivo (verbos no } \\
\text { presente) no passado composto, futuro simples. } \\
\text { Efeitos de corte e acelerção da imagem que têm como função diminuir o tamanho do } \\
\text { vídeo. }\end{array}$ \\
\hline
\end{tabular}




\begin{tabular}{|c|c|}
\hline \multicolumn{2}{|r|}{ Organização estrutural } \\
\hline $\begin{array}{l}\text { Vozes } \\
\text { discursivas }\end{array}$ & $\begin{array}{l}\text { Vozes dos participantes que aparecem em cena, vozes dos interlocutores, vozes de } \\
\text { instâncias sociais que aparecem por meio de palavras de outro lugar, outro tempo etc, } \\
\text { como indicado por Authier-Revuz (2002) } \\
\text { - indices não verbais de inserção de vozes: música, cenário, personagens, filmes; }\end{array}$ \\
\hline Modalizações & $\begin{array}{l}\text { Deônticas (equivalentes ao imperativo), lógicas (para persuadir o interlocutor a fazer o } \\
\text { tutorial) e apreciativas. }\end{array}$ \\
\hline Contato & $\begin{array}{l}\text { a) de interpelação: há uma ligação entre o participante em cena e o receptor através do } \\
\text { olhar convidando o interlocutor a participar do ato semiótico. } \\
\text { b) de exposição: o participante é observado pelo interlocutor e não há uma ligação pelo } \\
\text { olhar. }\end{array}$ \\
\hline $\begin{array}{l}\text { Distância } \\
\text { Social }\end{array}$ & a) Plano fechado: revela um grau de intimidade entre o enunciador e o receptor. \\
\hline $\begin{array}{l}\text { Atitude }- \\
\text { perspectiva }\end{array}$ & a) Ângulo frontal: aproximação afetiva entre o enunciador e o receptor. \\
\hline Modalidade & Contextualização através do cenário: cenário estruturado ou caseiro. \\
\hline
\end{tabular}

\section{Os procedimentos para a elaboração da sequência didática}

Neste momento, gostaríamos de trazer algumas considerações sobre a elaboração da sequência didática do gênero tutorial em vídeos. O nosso objetivo era fazer uma sequência mais longa em que pudéssemos trabalhar grande parte dos aspectos linguísticos observados no MD. No entanto, sabemos que, ao fazer a aplicação de atividades no contexto como o nosso, temos que considerar o programa curricular da escola (os conteúdos obrigatórios do semestre) e, consequentemente, o tempo para se trabalhar atividades que saem do programa ficam restritos. Diante disso, elaboramos uma sequência equivalente a seis módulos (sendo quatro módulos de uma hora e quarenta minutos e dois de cinquenta minutos para as apresentações das produções) adaptada aos conteúdos que deveriam ser estudados no terceiro trimestre das turmas, período no qual a atividade foi iniciada. Portanto, nossa SD teve que ser adequada ao tempo disponibilizado pela professora da turma e aos conteúdos que ela achava interessante trabalhar com os alunos, a partir do que apontamos em nosso MD.

Salientamos, também, que, ao iniciar a sequência, tivemos a informação de que os alunos já teriam o nível A1 segundo o Quadro Europeu Comum de Referência. Entretanto, ao iniciá-la, percebemos que os alunos estavam no nível iniciante, ou seja, 
início do A1. Diante disso, a sequência foi adaptada também de acordo com o nível dos alunos, que diagnosticamos mais precisamente após a primeira produção.

\section{A sequência didática do gênero tutorial em vídeos}

Neste momento, apresentaremos a sequência didática (SD) do gênero tutorial em vídeos. Primeiramente, apresentaremos um quadro síntese da sequência e, em seguida, a SD com algumas considerações sobre a sua aplicação 
Quadro 11: Síntese dos conteúdos trabalhados na sequência didática

\begin{tabular}{|c|c|c|}
\hline Aula & Conteúdo & Objetivos \\
\hline 1 & $\begin{array}{l}\text { Apresentação } \\
\text { da situação }\end{array}$ & $\begin{array}{l}\text { a) Instigar discussões sobre as novas tecnologias e suas redes de } \\
\text { compartilhamento de informações e sobre a sua função; discutir sobre a } \\
\text { função das redes sociais, se podemos aprender e/ou ensinar algo através } \\
\text { delas; } \\
\text { b) Assistir a um tutorial em vídeo com a finalidade de entender o seu } \\
\text { contexto de produção: quem os produz? para quem? com qual finalidade? } \\
\text { onde? } \\
\text { c) Organização da primeira produção: instigar a discussão sobre a primeira } \\
\text { discussão com o auxílio de uma tabela que auxilia na organização textual. }\end{array}$ \\
\hline 2 & $\begin{array}{l}\text { Apresentação } \\
\text { da produção } \\
\text { inicial }\end{array}$ & a) Apresentação dos tutoriais em vídeos produzidos pelos alunos. \\
\hline \multirow[t]{2}{*}{3} & $\begin{array}{l}\text { Bienvenus à } \\
\text { um nouveau } \\
\text { tuto! }\end{array}$ & $\begin{array}{l}\text { a) Trabalhar a compreensão oral por meio de um vídeo tutorial; } \\
\text { b) Discutir sobre contexto de produção dos vídeos; } \\
\text { c) Discutir sobre a recepção dos vídeos: se os alunos gostaram do vídeo, se } \\
\text { eles têm vontade de realizá-lo e seriam capazes de fazê-lo. }\end{array}$ \\
\hline & Les partitifs & $\begin{array}{l}\text { a) Refletir sobre a língua: atividade de conceitualização que leva os alunos } \\
\text { a construírem a regra de utilização dos artigos partitivos; } \\
\text { b) Memorizar os conteúdos linguísticos trabalhados: atividade de repetição } \\
\text { fazendo com que os alunos utilizem os artigos partitivos. }\end{array}$ \\
\hline \multirow[t]{2}{*}{4} & $\begin{array}{l}\text { Pour bien } \\
\text { expliquer le } \\
\text { processos de } \\
\text { préparation de } \\
\text { quelque chose }\end{array}$ & $\begin{array}{l}\text { a) Refletir sobre a língua: atividade de conceitualização dos organizadores } \\
\text { cronológicos; } \\
\text { b) Utilizar e memorizar os conteúdos trabalhados: atividade lúdica para } \\
\text { trabalhar o uso dos organizadores; }\end{array}$ \\
\hline & $\begin{array}{lr}\text { Pour } & \text { bien } \\
\text { expliquer } & \text { ce } \\
\text { qu'on } & \text { doit } \\
\text { faire } & \end{array}$ & $\begin{array}{l}\text { a) Assistir a um tutorial em vídeo seguido de uma discussão sobre os } \\
\text { tempos verbais encontrados no gênero vídeo tutorial; } \\
\text { b) Refletir sobre a língua: atividade de conceitualização com o intuito de se } \\
\text { trabalhar a regra do imperativo; } \\
\text { c) Memorizar os conteúdos linguísticos trabalhados: atividade lúdica com } \\
\text { o intuito de trabalhar o imperativo. } \\
\text { d) Trabalhar os focos de cinema: a contextualização (cenário) } \\
\text { e) Atividade para se trabalhar a abertura e a finalização dos tutoriais em } \\
\text { vídeos. }\end{array}$ \\
\hline 5 & Produção final & $\begin{array}{l}\text { a) Recapitular os conteúdos estudados durante a sequência completando a } \\
\text { ficha de auto avaliação que os guiará na produção final }\end{array}$ \\
\hline 6 & $\begin{array}{l}\text { Apresentação } \\
\text { da produção } \\
\text { final }\end{array}$ & a) Apresentar as produções finais dos tutoriais em vídeos. \\
\hline
\end{tabular}

A primeira aula teve por objetivo apresentar a situação e fazer com que os alunos iniciassem a primeira produção. Para chegar ao tema tutorial em vídeos, foi feita uma discussão sobre as redes sociais e aplicativos da internet e suas formas de interação: 


\section{POUR ECHOIJFFER...}

1. Connaissez-vous ces réseaux sociaux ? Discutez-en avec votre camarade :

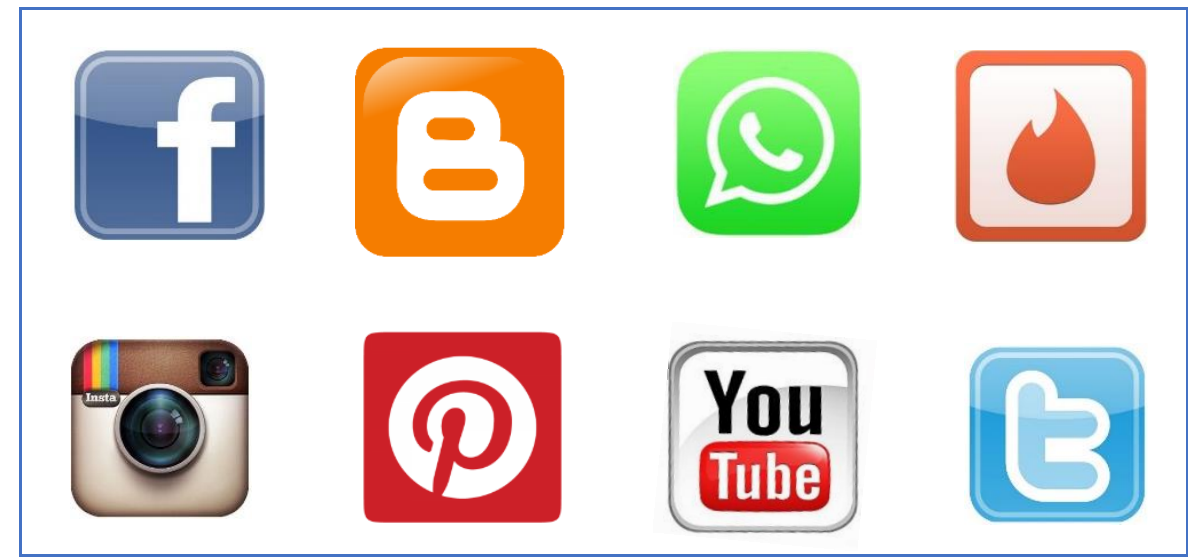

Celui-ci s'appelle...

On I'utilise pour...

Je ne connais pas celui-ci...

2. Maintenant, associez les images avec leurs descriptions et vérifiez ce que vous avez discuté :

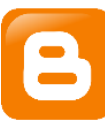

\section{You \\ Tube}
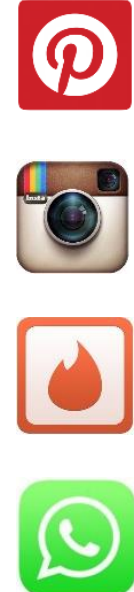

a. C'est une application de service de partage de photos et vidéos ;

b. C'est une plateforme gratuite qui facilite la publication d'un blog ;

c. C'est un site où on peut partager les centres d'intérêt, passions, hobbies à travers des albums de photographies sur internet;

d. C'est un réseau social qui permet à ses utilisateurs d'échanger des Messages et publier des informations;

e. C'est une application mobile qui permet d'envoyer de messages instantanée via internet;

f. C'est un site web où les utilisateurs peuvent regarder et partager des vidéos ; 


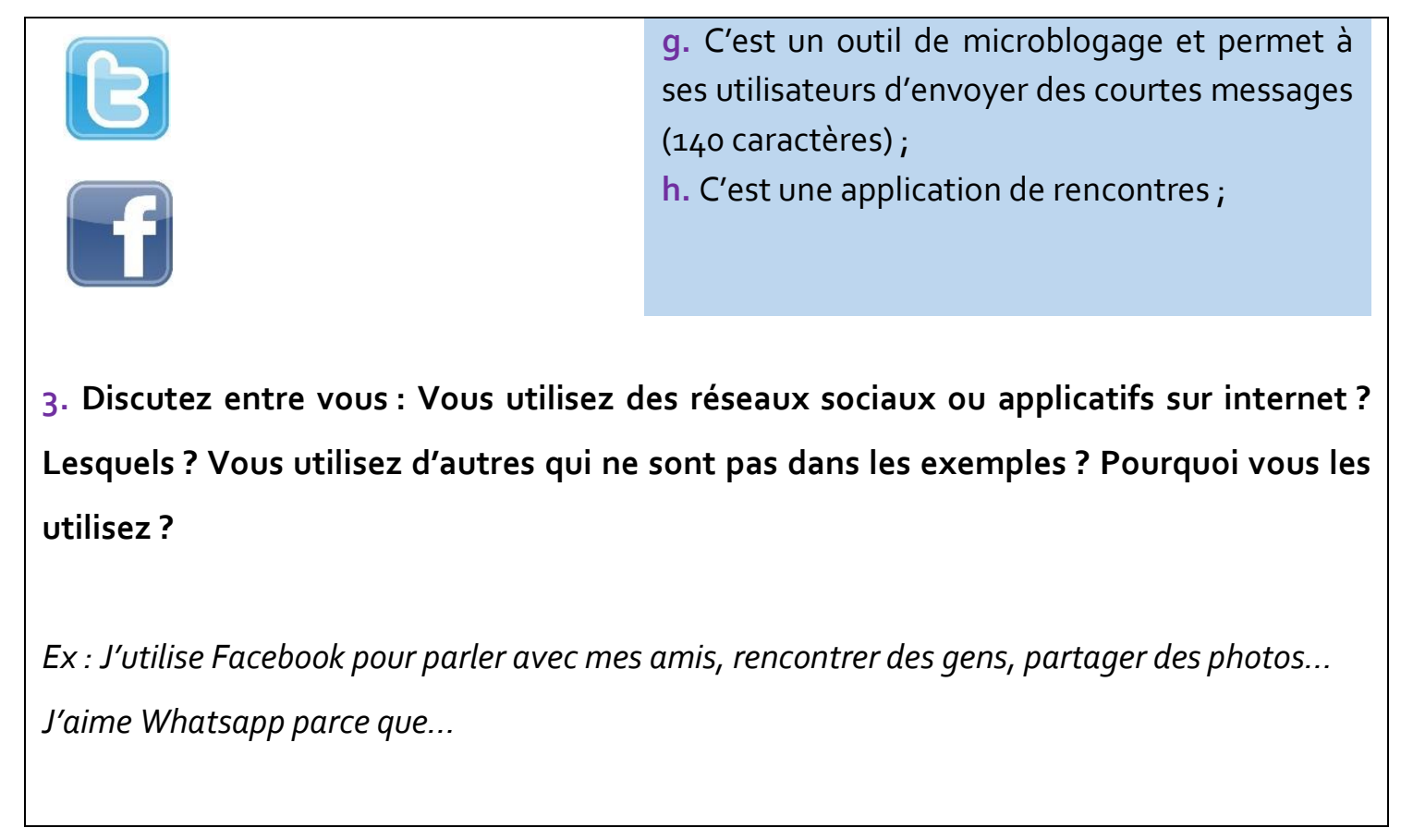

As discussões da atividade acima foram feitas em duplas ou trios e, a cada tópico, os alunos faziam um resumo do que foi discutido para a turma toda. Na atividade abaixo, tivemos como finalidade entrar no tema tutorial em vídeos para realizar a produção inicial:

\section{POUR RENTRER DANS LE SUJET...}

1. Apprenez-vous quelque chose ou avez-vous déjà enseigné quelque chose sur internet?

Discutez avec vos camarades.

2. Maintenant, observez l'image ci-dessous. De quoi s'agit-t-il ? Discutez à deux :

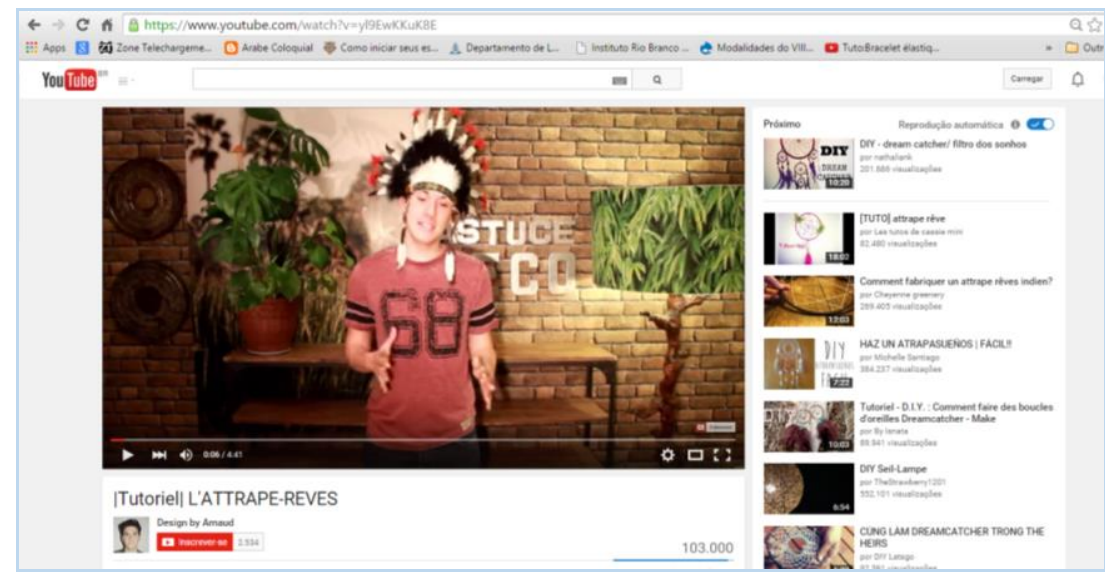


É importante ressaltar que a professora procurou não falar sobre o gênero com o qual se trabalharia para não estragar o effet surprise da atividade. Assim, através das discussões feitas com base na atividade acima, os alunos chegaram sozinhos ao tema da SD. Ao chegar ao tema, a reservou-se um tempo para a "apresentação da situação", momento no qual foi exposto o que os alunos trabalhariam ao longo da SD. Quanto ao assunto discutido, os alunos de ambas as turmas disseram que aprendem/estudam com o uso da internet, mas nunca ensinaram nada por meio dela. Dando sequência à atividade, tivemos por objetivo apresentar mais dois tutoriais em vídeos para que os alunos realizassem a produção inicial:

3. Regardez les vidéos tutoriels et discutez: Est-ce que vous aimez les vidéos ? Lesquelles vous aimez le plus? Pourquoi? Utilisez-vous des vidéos tutoriels pour apprendre quelque chose?

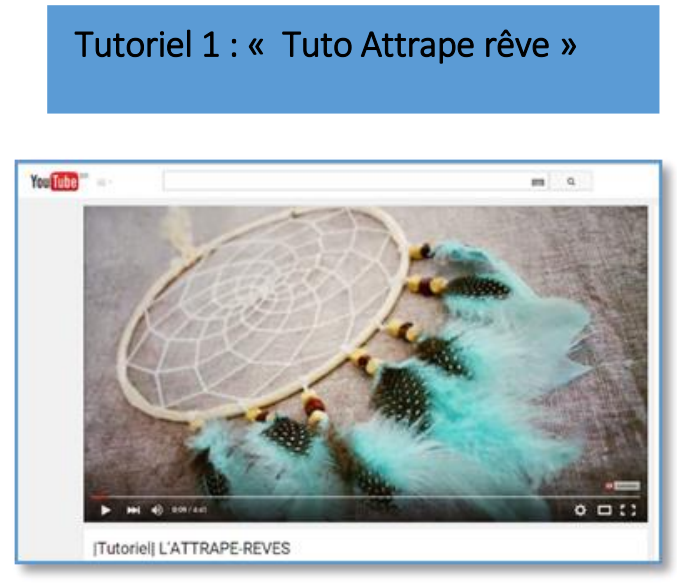

$$
\text { Tutoriel } 2 \text { : « Tuto Fimo : Le minion» }
$$

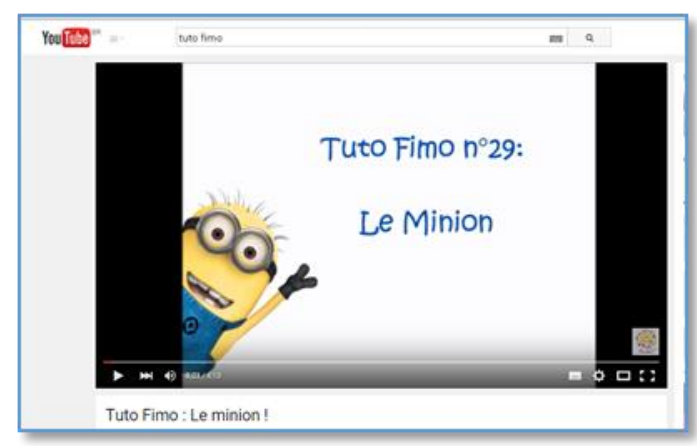

4. Avez-vous déjà fait une vidéo tutoriel ? Si oui, quels types de vidéos ?

5. Réféchissez au contexte : qui voit les tutoriels ? Qui les produit ?

Para a produção inicial, elaboramos uma tabela para que os alunos pudessem organizar a produção inicial como veremos abaixo: 


\section{J’APPRENDS LE FRANÇAIS EN ENSETGNANT QUELLQUE CHOSE A QUELLU'UN!}

Imaginez: Vous voulez enseigner quelque chose sur internet par vidéo. Par deux ou trois personnes, imaginez ce que vous allez présenter, organisez vos matériaux et présentez une vidéo tuto! Important : Soyez créatifs !

Pour créer votre vidéo tutoriel, organisez vos idées dans la grille ci-dessous :

1. Quel est le thème de votre tuto?

2. Qui va présenter?

3. À qui le tuto est destiné ?

4. Comment vous allez commencer la vidéo?

5. Comment vous allez finir?

6. Qui va filmer?

$\mathrm{Na}$ nossa coleta de dados, como ressaltado anteriormente, um dos objetivos é analisar as produções iniciais e finais dos alunos para saber se houve o desenvolvimento das capacidades de linguagem, bem como analisar as conversas trocadas pelos alunos durante as produções para saber quais indícios conseguimos perceber sobre do processo de produção e sobre o desenvolvimento dessas capacidades. Diante da impossibilidade de se fazer a produção em sala de aula (os alunos precisariam preparar o material, o 
local, pensar na edição do vídeo etc.), decidimos criar uma tabela para que eles pudessem discutir o que eles gostariam de ensinar e como eles fariam o vídeo, assim, teríamos a discussão da organização do texto gravada em áudio. Após completar a tabela, alguns alunos iniciaram a produção do texto em sala de aula.

Após a aula da apresentação das produções, iniciamos o primeiro módulo. Esta atividade teve por objetivo apresentar um novo tutorial aos alunos, trabalhar a compreensão oral e proporcionar a discussão sobre o contexto de produção dos vídeos: seus objetivos do vídeo e a quem o tutorial é destinado. Para essa aula, utlizamos o tutorial "Recette facile d'après soirée n" 6: Mug pizza/ Fast Good Cuisine"21

\section{BIENVENUS A UN NOUVEAU TUTO!}

1. Vous allez voir un nouveau tutoriel aujourd'hui: le tuto cuisine. D'abord, écoutez l'enregistrement et répondez aux questions:

Quelle est la recette proposée?
a. tarte;
c. jus d'orange ;
b. pizza ;
d. omelette.

2. Maintenant, regardez la vidéo, vérifiez vos réponses et cochez les ingrédients nécessaires pour réaliser cette recette :

a. Pour la pâte (6 ingrédients) :
( ) 3 cuillères à soupe de lait
( ) 4 cuillères à soupe de farine

( ) du sel

( ) du povre

( ) des œufs

( ) des herbes de Provence

( ) du sucre

( ) 1 cuillère à soupe d'huile d'olive

( ) 6 cuillères à soupe de farine

( ) 1 démi cuillère à café de levure chimique

b. Pour la garniture (6 ingrédients) :

( ) de la sauce tomate ( ) du jambon

${ }^{21}$ Disponível em: https://www.youtube.com/watch?v=6qzr1J_NnpI. Acesso em: 08 out. 2015. 


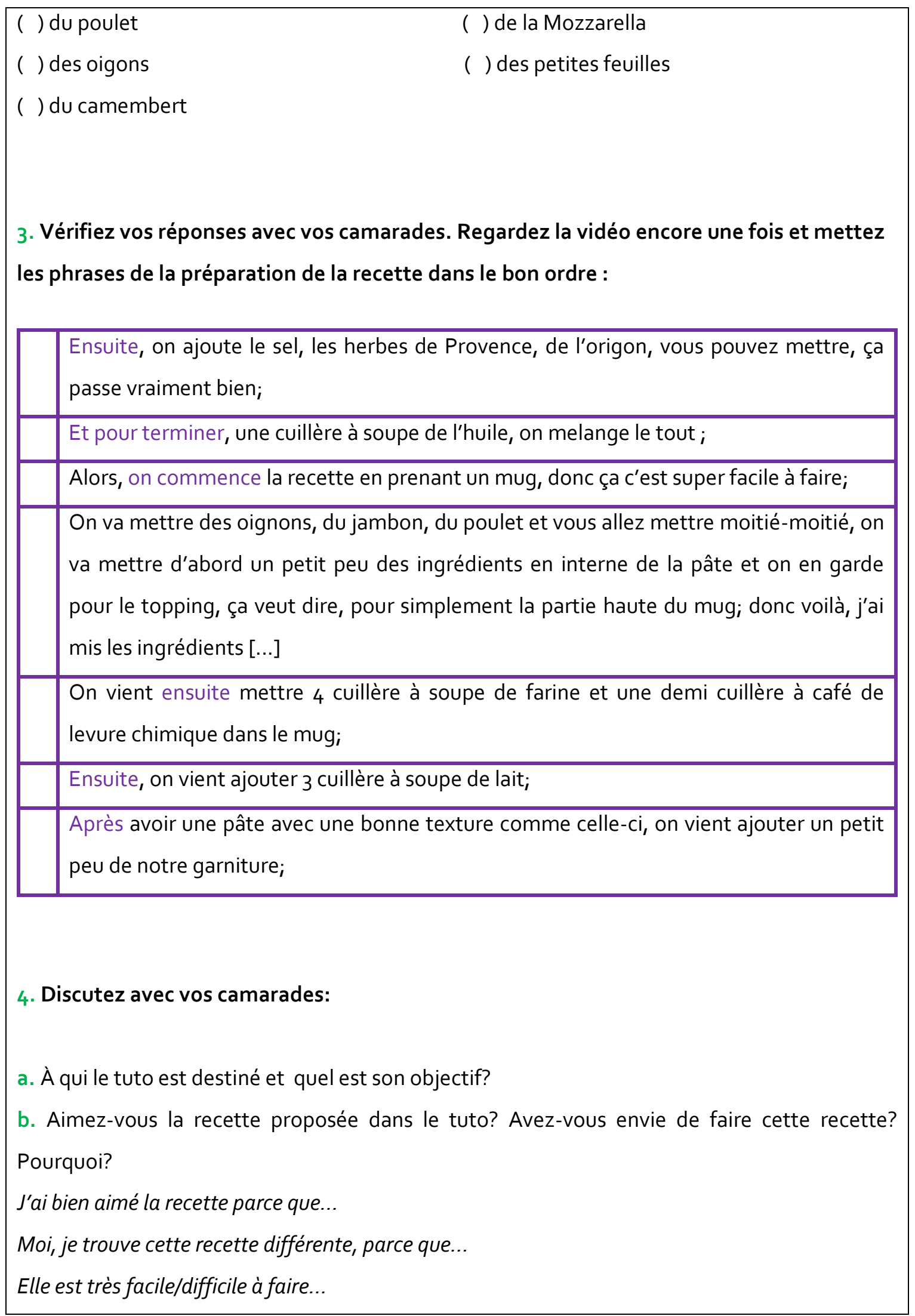

Após a discussão, aproveitamos o conteúdo do vídeo para se trabalhar os artigos partitivos, muito comuns nos tutoriais. Criamos uma atividade de conceitualização, ou 
seja, uma atividade na qual os alunos são levados a construir as regras tanto em relação ao uso, quanto em sua estrutura. Posteriormente à criação da regra, elaboramos uma atividade lúdica de repetição para que os alunos se apropriassem, aos poucos, desse aspecto linguístico. Por fim, a última atividade trazia os organizadores que auxiliam na progressão do texto.

\section{LES PARTITIFS - DU, DE LA, DEL', DES}

1. Observez les extraits de la vidéo et répondez aux questions en discutant avec vos camarades :

«On va mettre des oignons, du jambon, du poulet et vous allez mettre moitié-moitié ».

«On vient ensuite mettre 4 cuillères à soupe de farine ».

«On vient ajouter 3 cuillères à soupe de lait ».

( ) On utilise les partitifs quand on connaît la quantité exacte.

( ) On utilise les partitifs quand on ne connaît pas la quantité exacte.

2. Maintenant, complétez le tableau, ajouter les mots « feminin » et discutez la règle :

\begin{tabular}{|l|l|l|l|}
\hline & & Masculin & Voyelle \\
\hline Singulier & de la farine & \multicolumn{1}{c}{ jambon; } & $\frac{\text { de l'eau } \quad \text { de }}{\text { l'huile }}$ \\
\hline Pluriel & Des fraises, __ oignons & _ \\
\hline
\end{tabular}

\section{Aujourd'hui je vais manger...}

Faites une demi ronde avec les chaises de la salle de classe. Imaginez : Vous vous êtes réveillé et vous allez prendre le petit déjeuner. Qu'est-ce que vous allez manger? Une personne va commencer la phrase «Aujourd'hui je vais manger... » et la personne à sa droite va dire : «Aujourd'hui elle va manger... et moi, je vais manger... » et vous tournez 2 fois la demi ronde. Vous pouvez utiliser le vocabulaire ci-dessous et ajouter d'autres aliments, si vous voulez! Et bien sûr, n'oubliez pas d'utiliser les partitifs! 


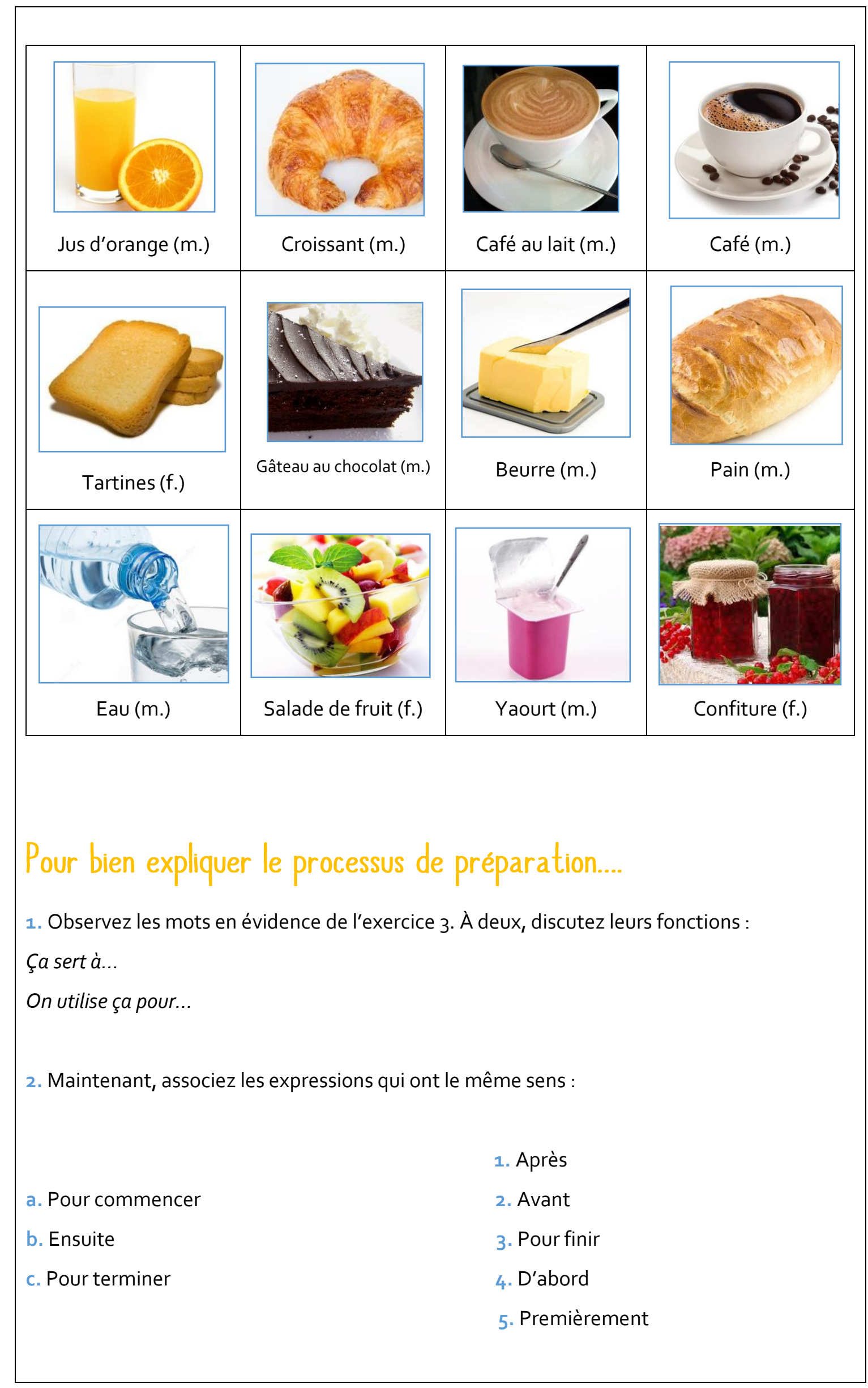


Imaginez: Vous êtes dans un café et comme vous êtes très gourmand(e), vous voulez tout manger. Vous allez raconter à votre camarade tout ce que vous allez manger. N'oubliez pas : Utilisez les partitifs pour les choses dont on ne peut pas dire la quantité exacte et les organisateurs chronologiques pour bien raconter.

Ex: D'abord, je vais manger du pain au chocolat et boire du jus d'orange. Ensuite, je vais manger de la tarte aux fraises....

A aula do módulo II tem como objetivo trabalhar os tempos verbais utilizados nos tutoriais, mais especificamente o imperativo. O vídeo utilizado foi o "Maquillage de fausse blessure/de gruffures profondes - Tutoriel de maquillage Halloween "22

\section{Pour bien expliquer ce qu'on doit faire...}

1. Regardez la vidéo de maquillage artistique et observez les phrases ci-dessous: Quels sont le temps verbaux utilisés?

a. Avant tout, dégage tes cheveux avec l'aide d'un bandeau ou d'un bonnet...

b. Tu peux, maintenant, poser une base de teint...

c. On commence par les yeux. Place des petites marques...

d. Maintenant, on passe au nez. Pince l'arrêt de ton nez .
( ) présent
( ) Imparfait
( ) passé composé
( ) Impératif

2. Observez les exemples et compétez le tableau :

Tu commences par les yeux. V Vous passez au nez. Vous pincez l'arrêt de votre nez.

Commence par les yeux.

Passez au nez. Pincez l'arrêt de ton nez.

${ }^{22}$ Disponível em: https://www.youtube.com/watch?v=ZTvLBAnbMGM. Acesso em 08 out. 2015. 


\begin{tabular}{|l|l|}
\hline \multicolumn{1}{|c|}{ Présent } & \multicolumn{1}{c|}{ Impératif } \\
\hline Tu commences par les yeux. & par les yeux. \\
\cline { 2 - 2 } Nous marquons la bouche. & la bouche. \\
\hline au nez. & Passez au nez. \\
\hline
\end{tabular}

3. Dites si c'est vrai ou faux

( ) On utilise l'impératif pour donner des ordres, des conseils et pour expliquer comment faire quelque chose.

( ) On utilise l'impératif avec les pronoms personnels «Tu », « nous » et « ils/elles ».

( ) L'impératif a la même conjugaison des verbes au présent, sauf pour les verbes en ER à la deuxième personne du singulier, « tu ». parce qu'on enlève le « $s$ » final.

4. Yoga insolite!

A atividade Yoga insolite foi feita da seguinte forma: a professora pediu aos alunos para se levantarem e começou a dar as orientações do que os alunos devem fazer: "primeiramente, levantem a perna direita, com a perna direita levantada, fechem o olho esquerdo, agora inclinem a cabeça para a direita etc". Em seguida, a professora pediu para um outro aluno ser o "professor de yoga". Dessa forma, os alunos puderam colocar em prática o imperativo, tempo verbal recorrente nos tutoriais em vídeos.

$\mathrm{Na}$ atividade abaixo, tivemos por objetivo trabalhar os focos de cinema descritos no modelo didático, pois através deles, vimos que podemos dar ênfase a determinado objeto. Em seguida, o foco da aula passou para o cenário: alguns tutoriais são mais "caseiros" e outros possuem um cenário mais estruturado e que auxilia na compreensão do texto. 


\section{Pour bien montrer comment faire quelque chose...}

1. Observez les images ci-dessous: Pourquoi les images sont quelques fois plus loin et d'autres fois, plus près? Discutez entre vous.

Tuto 1 : Comment fabriquer une lampe bat signal :
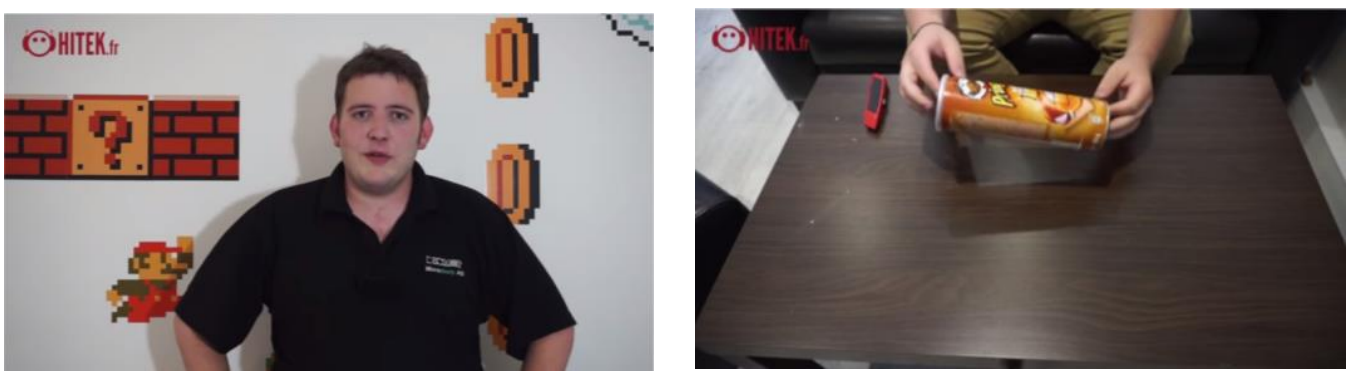

Tuto 2 : Maquillage simple et naturel en 5 minutes
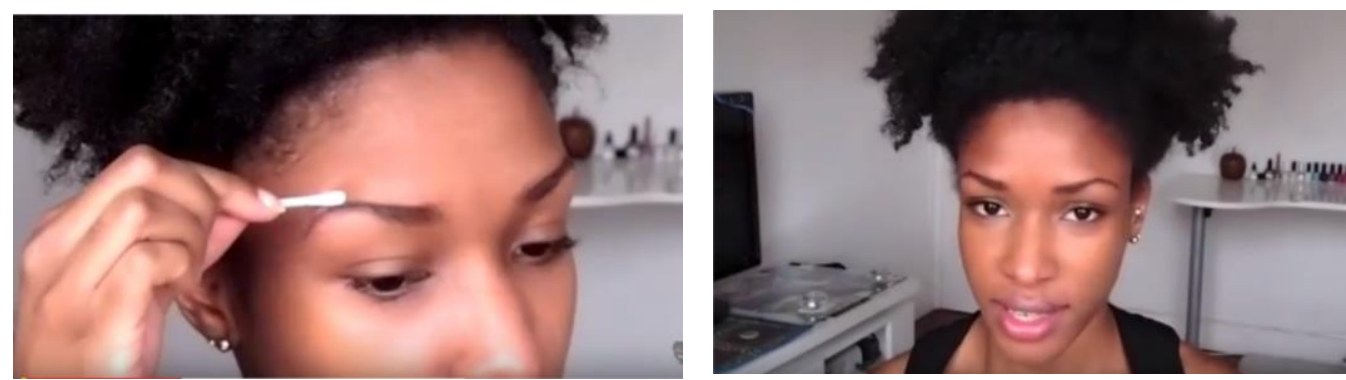

2. Maintenant, observez l'ambiance où les tutos sont enregistrés. Que pouvez-vous constater? Discutez entre vous.

Após a atividade com foco nas imagens, na atividade "pour montrer que le tuto est intéressant", demos novamente o enfoque aos objetivos de se fazer um tutorial. Refletindo sobre as práticas sociais, hoje, além de ter o objetivo de ensinar alguma coisa, muitos usuários da internet também tem o intuito de serem reconhecidos, receber likes e conquistar seguidores. A partir dessa reflexão, elaboramos uma atividade em que os alunos são levados a refletir sobre o que fazer para conseguir atingir esses objetivos. Com essa atividade, visamos desenvolver as capacidades de linguagem dos alunos, nesse caso, mais especificamente as capacidades-linguístico discursivas como as modalizações, por exemplo. 


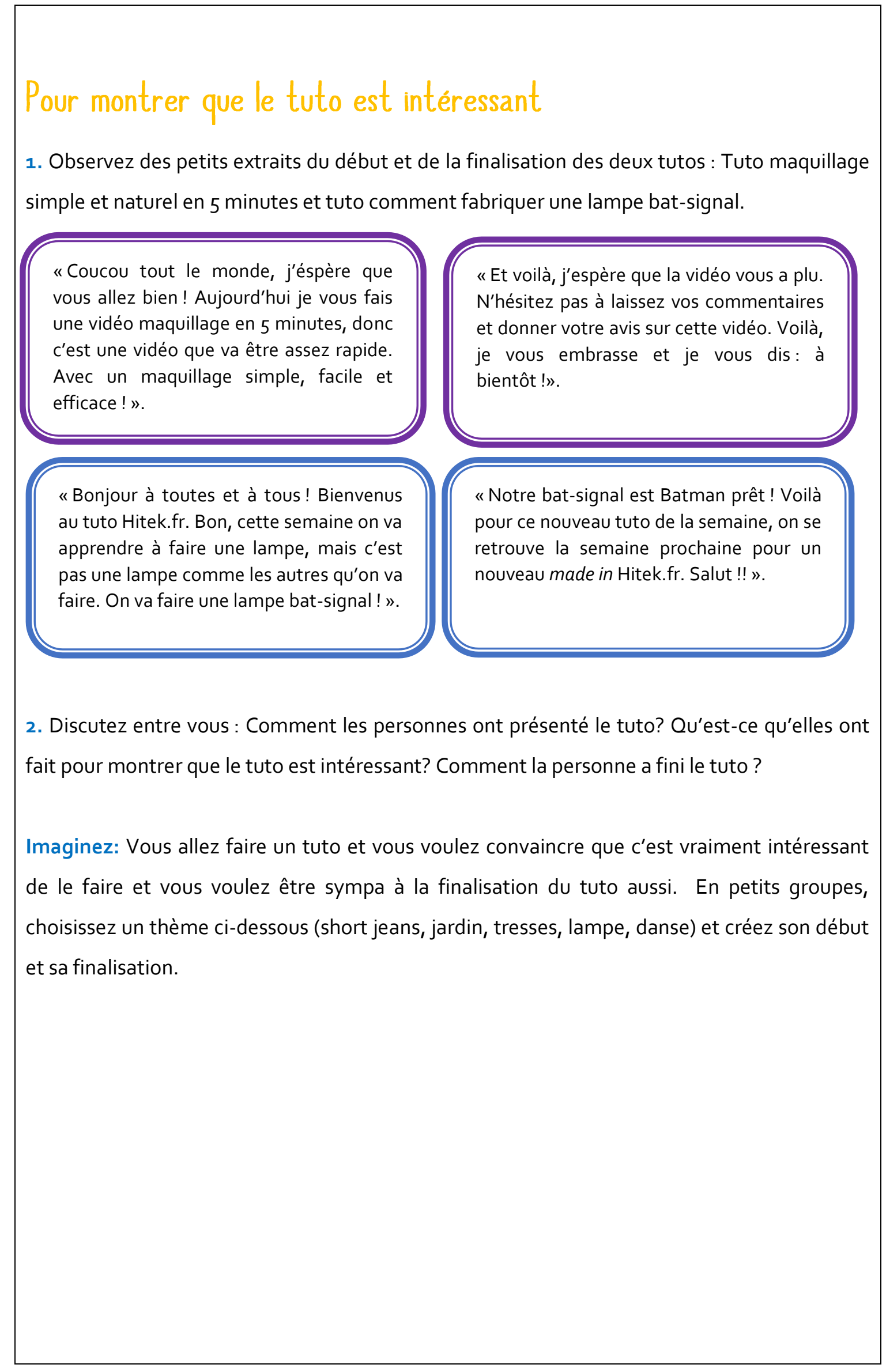




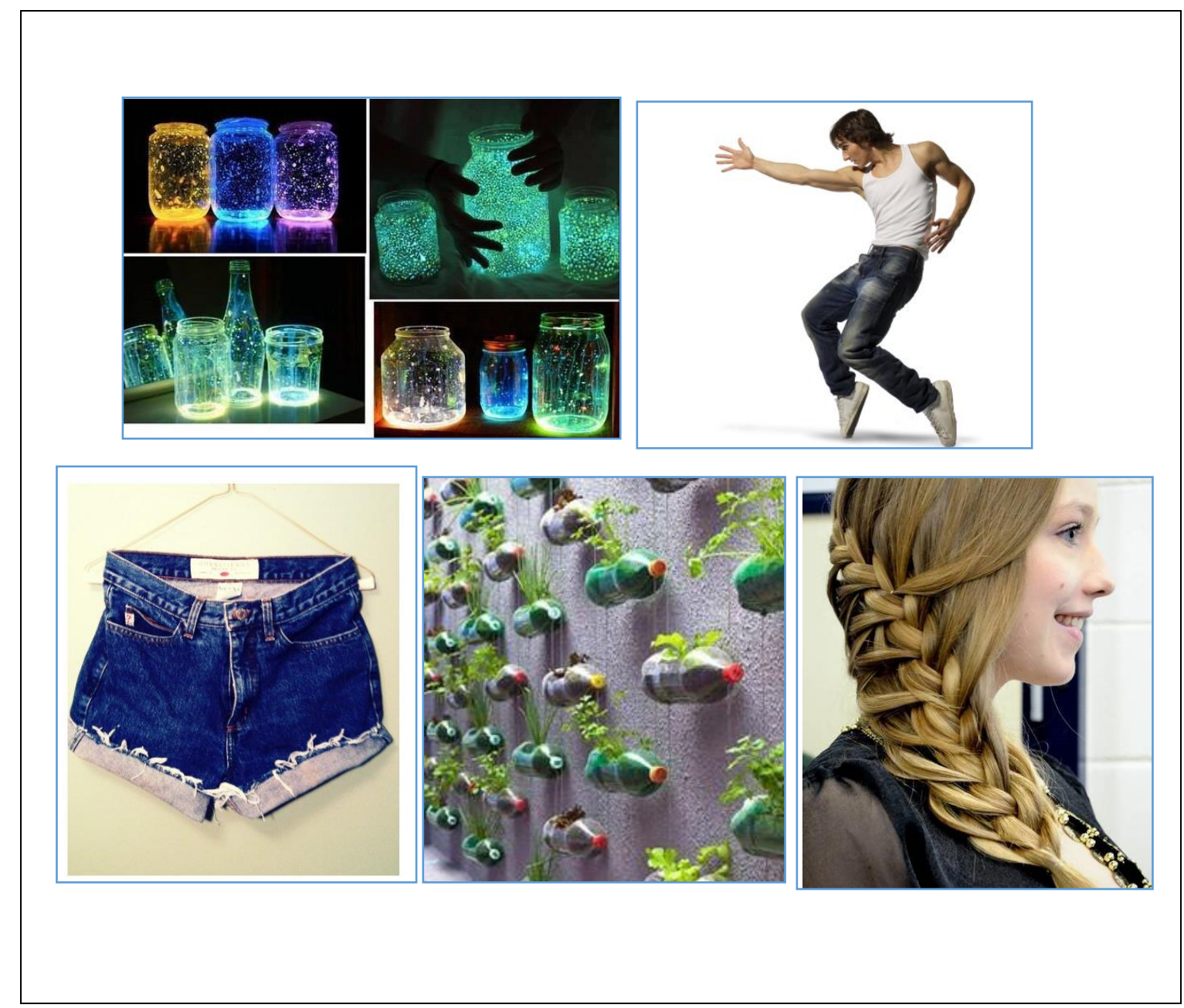

Após dois módulos de atividades, na última aula tivemos o intuito de recapitular todos os conteúdos vistos ao longo da sequência e fazer com que os alunos elaborassem uma ficha de auto avaliação para guiá-los na produção final. $\mathrm{Na}$ ficha entregue aos alunos, as partes sublinhadas estavam em branco, para que ela fosse completada ao longo da discussão.

\section{Aujourd'hui on va faire un nouveau tuto...}

Vous êtes presque un spécialiste en tutos!

Avec la professeure, vous allez faire une liste de choses que vous avez observées dans les tutos et qui sont importantes pour enseigner quelque chose à partir des vidéos tutos! Réfléchissez aux questions suivantes : 


\section{Fiche d'autoévaluation:}

Discutez avec la professeure vos objectifs et que vous devez faire pour atteindre vos objectifs pour faire la vidéo tuto. Complétez le tableau ci-dessous avec des aspects que vous avez discutez:

Objectifs :

Comment faire pour atteindre vos
objectifs?

1. Enseigner quelque chose

1. Avez-vous utilisé les organisateurs chronologiques « d'abord, ensuite, après...)? 2.Avez-vous utilisé l'impératif ou le présent?; 3. Avez-vous fait une bonne préparation ?; 4. Avez-vous fait attention à la prononciation?;

5. Avez-vous montré les matériaux nécessaires?

6. Avez-vous utilisé les « focus cinéma » ?. Autres:

2. Convaincre les personnes à faire ce 1 . Avez-vous fait la pub ? tuto ( Montrer que c'est rapide, que $c^{\prime}$ est savoureux etc.)

Autres :

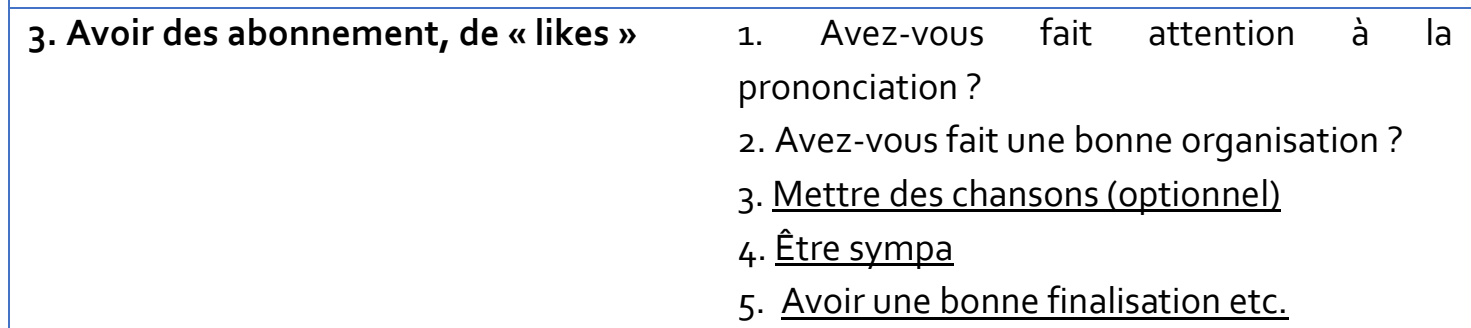

4. Autres

Et voilà, vous pouvez commencer votre tuto! N'oubliez pas d'utiliser le tableau que vous avez créé !

Finalizada a apresentação da nossa SD, na próxima seção, apresentaremos os instrumentos de coleta de dados da nossa pesquisa. 


\section{Instrumentos de coleta de dados}

A aplicação da SD gerou os seguintes instrumentos de coleta de dados:

I - As produções inicial e final de duas turmas da EAFEUSP;

II - Gravações das conversas dos alunos no momento da produção inicial e final dos alunos e no horário de atendimento oferecido pela professora;

III - Diário de bordo da professora-pesquisadora;

\begin{tabular}{|l|c|l|ll|}
\hline \multicolumn{1}{|c|}{ Instrumento de coleta } & $\begin{array}{c}\text { Período de } \\
\text { coleta }\end{array}$ & \multicolumn{1}{|c|}{ Quantidade } & \multicolumn{2}{|c|}{ Tipo de análise } \\
\hline $\begin{array}{l}\text { Produções textuais dos } \\
\text { alunos }\end{array}$ & $\begin{array}{c}01 / 09 / 2015 \\
\text { à } \\
29 / 10 / 2015\end{array}$ & $\begin{array}{l}12 \text { (6 iniciais e 6 } \\
\text { finais) }\end{array}$ & $\begin{array}{l}\text { Texto verbal e } \\
\text { visual }\end{array}$ & \\
\hline $\begin{array}{l}\text { Gravações das conversas } \\
\text { dos alunos no momento } \\
\text { das produções }\end{array}$ & $\begin{array}{c}01 / 09 / 2015 \\
\text { à }\end{array}$ & $\begin{array}{l}8 \text { (4 no momento da } \\
\text { produção inicial e 4 } \\
\text { no momento da } \\
\text { produção final) }\end{array}$ & Texto verbal & \\
\hline $\begin{array}{l}\text { Diário de bordo da } \\
\text { professora-pesquisadora }\end{array}$ & $\begin{array}{c}01 / 09 / 2015 \\
\text { à }\end{array}$ & $\begin{array}{l}8 \text { momentos (6 } \\
\text { relatando as aulas e } \\
29 / 10 / 2015 \\
\text { relatando os } \\
\text { atendimentos } \\
\text { oferecidos fora do } \\
\text { horário da aula) }\end{array}$ & & \\
\hline
\end{tabular}

\section{Procedimentos de seleção de dados}

Para selecionar os dados analisados na nossa pesquisa, adotamos os seguintes procedimentos:

I) Produções dos alunos: dentre as produções textuais dos alunos, foram analisados as produções dos grupos que entregaram as duas produções: a inicial e a final;

II) Conversas gravadas dos alunos no momento das produções: por problemas de má qualidade de um dos gravadores, tivemos que restringir a nossa análise a apenas quatro grupos de alunos. 


\section{Procedimentos para análise dos dados}

Com a finalidade de verificar se, através da SD, houve o desenvolvimento das capacidades de linguagem dos alunos, analisaremos as produções iniciais e finais com base no quadro da Semiótica Sociointeracional proposto por Leal (2011) juntamente com o MD do gênero tutorial. Assim, o desenvolvimento das capacidades de ação será analisado a partir do contexto de produção; a partir da organização temático representacional e interacional, analisaremos as capacidades discursivas e, por meio da organização estrutural, observaremos o desenvolvimento das capacidades linguísticodiscursivas. Para facilitar a análise, elaboramos um quadro síntese para analisar as produções dos alunos:

Quadro 12: Capacidades de ação: operações de linguagem esperadas para a produção do vídeo tutorial em relação ao contexto de produção

\begin{tabular}{|l|l|}
\hline \multicolumn{2}{|l|}{ Capacidade de ação: operações de linguagem esperadas para a produção do vídeo tutorial em } \\
relação ao contexto de produção
\end{tabular}


Quadro 13: Capacidades discursivas: operações de linguagem esperadas para a produção do vídeo tutorial em relação a organização temático-representacional

\begin{tabular}{|c|c|c|}
\hline \multicolumn{3}{|c|}{$\begin{array}{l}\text { Capacidades discursivas: operações de linguagem esperadas para a produção do vídeo tutorial em } \\
\text { relação a organização temático-representacional }\end{array}$} \\
\hline \multirow[t]{3}{*}{$\begin{array}{l}\text { Organização } \\
\text { temático- } \\
\text { representacional } \\
\text { verbal }\end{array}$} & $\begin{array}{l}\text { Plano global dos } \\
\text { conteúdos } \\
\text { temáticos }\end{array}$ & $\begin{array}{l}\text { a) logo } \\
\text { a) Título do tutorial; } \\
\text { b) saudação; } \\
\text { c) apresentação do que será realizado; } \\
\text { - Possibilidade de justificativa da realização do vídeo, função } \\
\text { daquilo que está sendo ensinado, apreciação do enunciador sobre } \\
\text { o que será ensinado; } \\
\text { d) materiais utilizados; } \\
\text { e) modo de fazer; } \\
\text { f) resultado final; } \\
\text { - Possibilidade de comentário do enunciador em relação ao vídeo; } \\
\text { g) agradecimentos e convite para "curtir" e seguir o enunciador. } \\
\text { h) despedida. }\end{array}$ \\
\hline & $\begin{array}{l}\text { Tipos } \\
\text { discurso }\end{array}$ & $\begin{array}{l}\text { Discurso interativo (expor implicado) por serem ligados ao } \\
\text { mundo ordinário e por apresentar implicação através de dêiticos } \\
\text { de pessoas, espaciais e temporais. }\end{array}$ \\
\hline & $\begin{array}{ll}\text { Tipos de } \\
\text { sequência }\end{array}$ & $\begin{array}{l}\text { Presença de uma macro sequência dialogal; } \\
\text { Sequência descritiva de ações que encontramos, por exemplo, em } \\
\text { uma receita ou um manual de instruções; } \\
\text { Possibilidade de efeito argumentativo global sem que apresentem } \\
\text { sequências argumentativas completas. }\end{array}$ \\
\hline $\begin{array}{l}\text { Organização } \\
\text { temático- } \\
\text { representacional } \\
\text { não verbal }\end{array}$ & $\begin{array}{l}\text { Tipos de } \\
\text { representações }\end{array}$ & $\begin{array}{l}\text { Representações narrativas: quando há uma ação na cena } \\
\text { comunicativa. } \\
\text { a) de reação: quando o participante da cena volta o olhar para } \\
\text { outro (pouco recorrente); } \\
\text { b) de ação: o participante age sobre determinada pessoa ou } \\
\text { objeto; } \\
\text { Representações conceituais: inexistência de ação entre os } \\
\text { participantes ou objetos na cena comunicativa, normalmente } \\
\text { apresentados por um objeto simbólico ou quando se quer dar } \\
\text { ênfase no objeto a ser ensinado. }\end{array}$ \\
\hline
\end{tabular}


Quadro 14: Capacidades linguístico-discursivas: operações de linguagem esperadas para a produção do vídeo tutorial em relação a organização interacional e organização estrutural verbal

Capacidades linguístico-discursivas: operações de linguagem esperadas para a produção do vídeo tutorial em relação a organização interacional e organização estrutural verbal

\begin{tabular}{|c|c|c|}
\hline $\begin{array}{l}\text { Organização } \\
\text { estrutural não } \\
\text { verbal }\end{array}$ & $\begin{array}{l}\text { Valor } \mathrm{da} \\
\text { informação }\end{array}$ & Centrada e não polarizada. \\
\hline \multirow[t]{2}{*}{$\begin{array}{l}\text { Organização } \\
\text { estrutural verbal }\end{array}$} & Conexão & $\begin{array}{l}\text { D'abord, prémièrement, ensuite, pour finir, après, finalement, } \\
\text { etc. voilà, alors }\end{array}$ \\
\hline & Coesão & $\begin{array}{l}\text { a) Nominal: demonstrativos, catáforas, anáforas, } \\
\text { partitivos/quantidade medida exata. } \\
\text { b) Verbal: predomínio do imperativo, mas encontramos } \\
\text { também o infinitivo (verbos no presente) no passado } \\
\text { composto, futuro simples. } \\
\text { - efeitos de corte e acelerção da imagem que têm como função } \\
\text { diminuir o tamanho do vídeo. }\end{array}$ \\
\hline \multirow[t]{6}{*}{$\begin{array}{l}\text { Organização } \\
\text { interacional }\end{array}$} & $\begin{array}{l}\text { Vozes } \\
\text { discursivas }\end{array}$ & $\begin{array}{l}\text { Vozes dos participantes que aparecem em cena, vozes dos } \\
\text { interlocutores, vozes de instâncias sociais que aparecem por } \\
\text { meio de palavras de outro lugar, outro tempo etc, como } \\
\text { indicado por Authier-Revuz (2002) } \\
\text { - indices não verbais de inserção de vozes: música, cenário, } \\
\text { personagens, filmes; }\end{array}$ \\
\hline & Modalizações & $\begin{array}{l}\text { Deônticas (equivalentes ao imperativo), lógicas (para } \\
\text { persuadir o leitor a fazer o tutorial) e apreciativas. }\end{array}$ \\
\hline & Contato & $\begin{array}{l}\text { a) de interpelação: há uma ligação entre o participante em cena } \\
\text { e o receptor através do olhar convidando o interlocutor a } \\
\text { participar do ato semiótico. } \\
\text { b) de exposição: o participante é observado pelo interlocutor e } \\
\text { não há uma ligação pelo olhar. }\end{array}$ \\
\hline & Distância Social & $\begin{array}{l}\text { a) Plano fechado: revela um grau de intimidade entre o } \\
\text { enunciador e o receptor. }\end{array}$ \\
\hline & $\begin{array}{l}\text { Atitude - } \\
\text { perspectiva }\end{array}$ & $\begin{array}{l}\text { a) Ângulo frontal: aproximação afetiva entre o enunciador e } o \\
\text { receptor. }\end{array}$ \\
\hline & Modalidade & $\begin{array}{l}\text { Contextualização através do cenário: cenário estruturado ou } \\
\text { caseiro. }\end{array}$ \\
\hline
\end{tabular}




\section{CAPÍTULO III - RESULTADO DAS ANÁLISES}

Apresentaremos, neste momento, a análise das produções textuais, tanto iniciais como finais dos alunos com os quais trabalhamos nesta pesquisa. Como salientado anteriormente, analisamos somente os grupos que entregaram as duas produções (iniciais e finais), uma vez que o nosso objetivo foi fazer uma análise comparativa das produções para saber se, através da sequência com base no gênero tutorial em vídeos, houve os desenvolvimento das capacidades de linguagem dos alunos, a saber: as capacidades de ação, as discursivas e as linguístico discursivas (DOLZ, PASQUIER, BRONCKART, 1993). Assim, tivemos três produções iniciais e finais de cada turma, como podemos observar no quadro abaixo:

Quadro 15: Produções iniciais e finais da turma A

\begin{tabular}{|c|l|l|l|}
\hline Grupo & Integrantes & Produção inicial & Produção final \\
\hline 1 & Luna, Renan, Bernardo & $\begin{array}{l}\text { Tuto de lait au chocolat } \\
\text { (01:09 min) }\end{array}$ & $\begin{array}{l}\text { Tuto Pomo d'or (2:07 } \\
\text { min) }\end{array}$ \\
\hline 2 & Sofia, Leo, Nina & $\begin{array}{l}\text { Tuto tarte au bis }(01: 53 \\
\text { min) }\end{array}$ & $\begin{array}{l}\text { Tuto comme (sic) faire } \\
\text { une poudre de couleur } \\
(01: 27 \text { min })\end{array}$ \\
\hline 3 & Beatriz, Julia, Arthur & La Brigadero (01:44 min) & Tye Dye (01:58 min) \\
\hline
\end{tabular}

Quadro 16: Produções iniciais e finais da turma B

\begin{tabular}{|c|l|l|l|}
\hline Grupo & Integrantes & Produção inicial & Produção final \\
\hline $1^{23}$ & André & $\begin{array}{l}\text { Comment dessiner au } \\
\text { style manga }(01: 29 \text { min })\end{array}$ & $\begin{array}{l}\text { Comment dessiner les } \\
\text { yeux au style manga } \\
(04: 17 \text { min })\end{array}$ \\
\hline 2 & Marina, Bruno & $\begin{array}{l}\text { Comment faire um skate } \\
(01: 44 \text { min })\end{array}$ & $\begin{array}{l}\text { Comment faire "ollie” } \\
(01: 58 \text { min })\end{array}$ \\
\hline 3 & $\begin{array}{l}\text { Bianca, Alice, Gustavo, } \\
\text { César }\end{array}$ & $\begin{array}{l}\text { Tuto gâteau au chocolat } \\
\text { végétarien }(04: 59 \text { min })\end{array}$ & $\begin{array}{l}\text { Comment fait ( } \text { sic }) \text { um } \\
\text { crapaud (03:35 min) }\end{array}$ \\
\hline
\end{tabular}

\footnotetext{
${ }^{23}$ Este aluno optou por fazer as produções individualmente, mas deixamos o termo "grupo" para facilitar a nossa construção textual.
} 
Para uma maior compreensão de como foi feita a análise dos vídeos, abaixo, trouxemos um trecho do detalhamento de uma produção dos alunos. Esse detalhamento, elaborado com base em Barioni (2011), em uma pesquisa na qual a autora propõe uma sequência didática com base em receitas audiovisuais ${ }^{24}$ foi feito em todos os vídeos para facilitar a nossa análise (anexo), uma vez que temos articulados no vídeo, imagens, textos oral e escrito, sons e efeitos. Parte da produção final do grupo 1, o trecho destacado é o detalhamento de vinte e sete segundos do vídeo, sendo que o vídeo tem a duração de dois minutos e sete segundos.

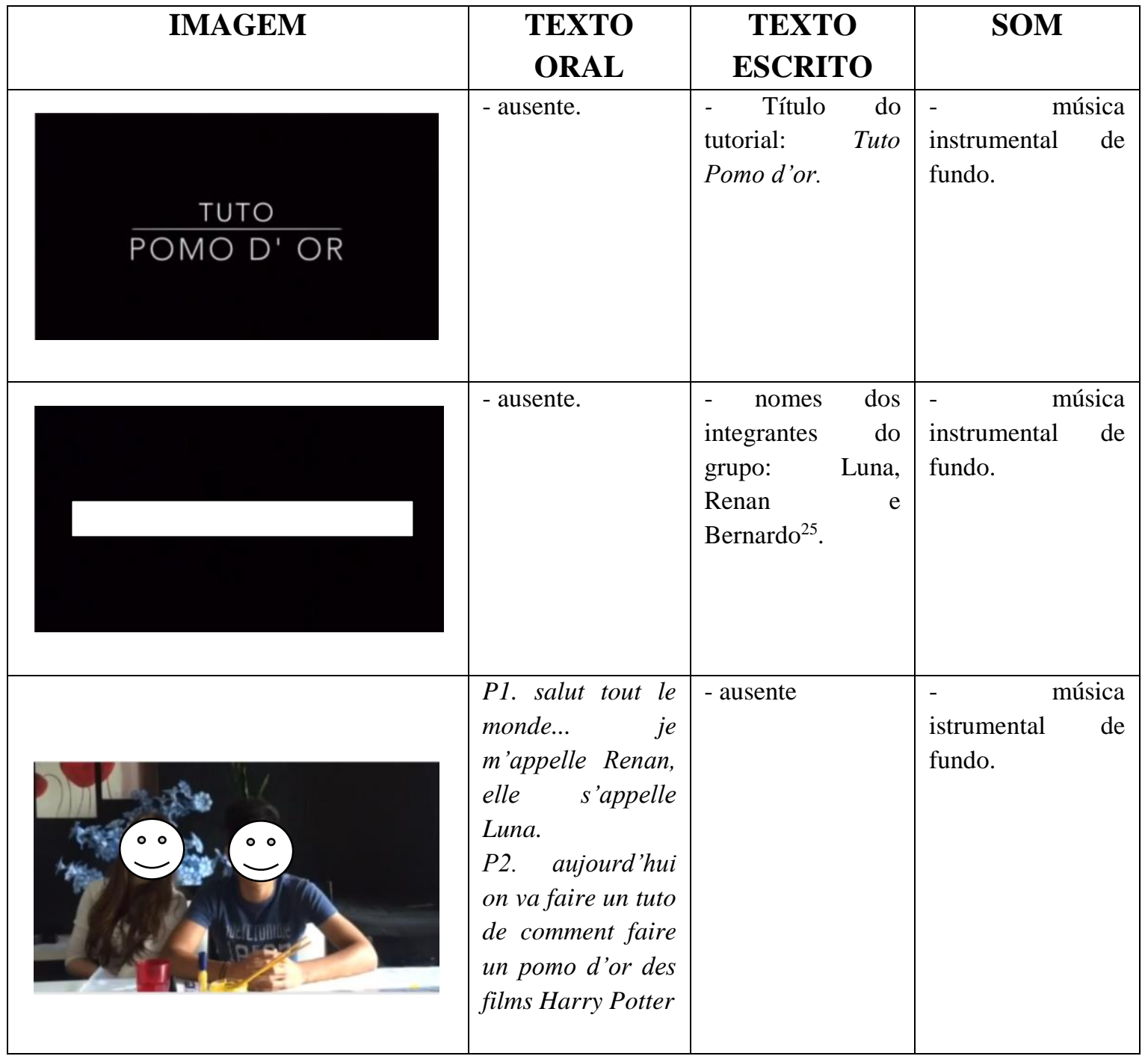

${ }^{24}$ Para realizar este detalhamento, nos baseamos na tabela proposta na comunicação "Gêneros textuais digitais no ensino da língua francesa: a receita audiovisual" (Barioni, 2011) em que a autora propõe uma sequência didática com base em receitas audiovisuais.

${ }^{25}$ Com o intuito de preservar a imagem dos participantes da pesquisa, os nomes dos integrantes presentes na imagem foram apagados, os nomes presentes nas transcrições são fictícios e os rostos dos participantes foram cobertos. 


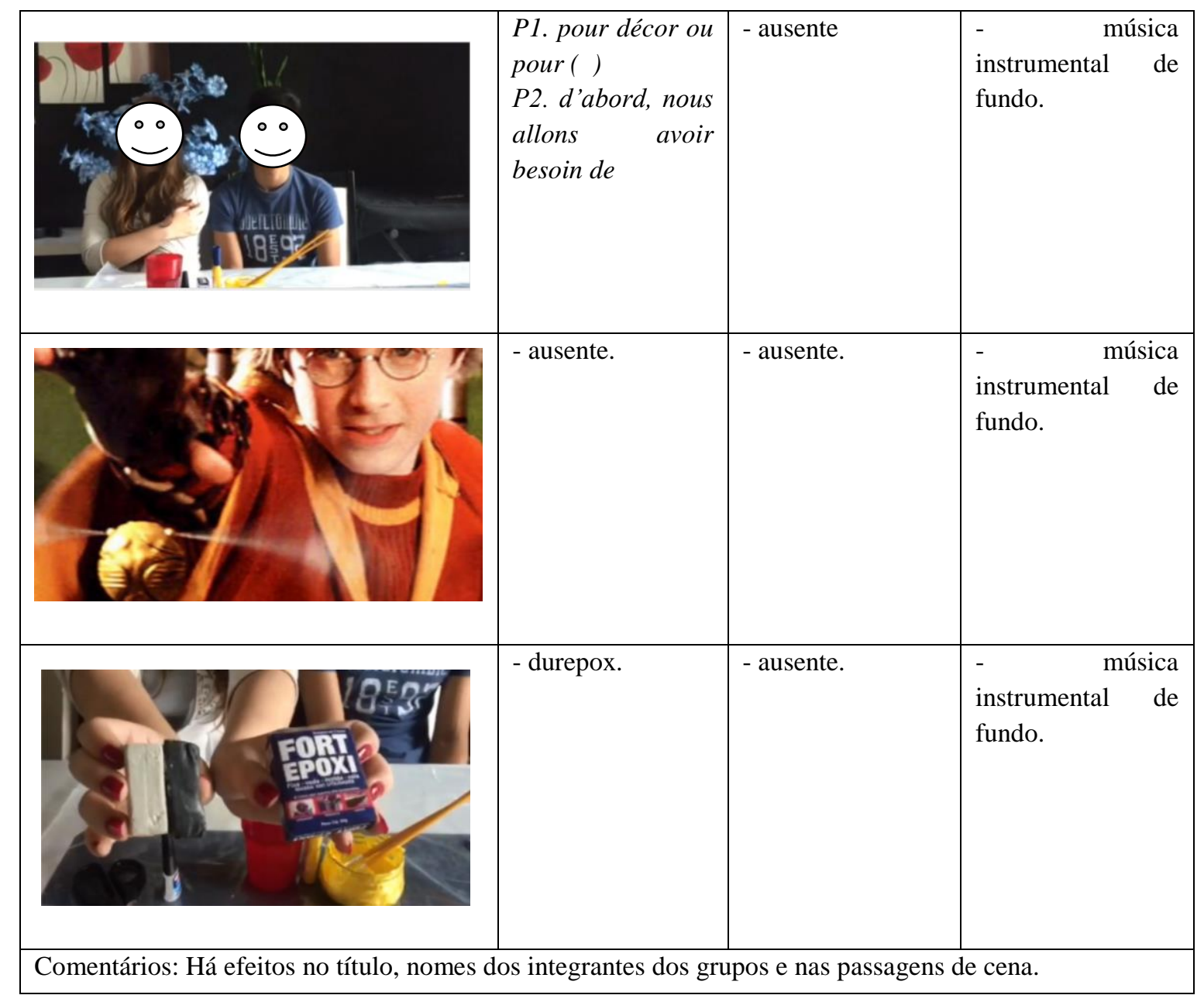

Assim, nas produções iniciais e finais de cada turma, observamos a mobilização das capacidades necessárias para a produção do gênero tutorial em vídeos através dos seguintes critérios: se houve a mobilização de várias capacidades necessárias para a produção do gênero; se houve a mobilização de algumas das capacidades necessárias; e se não houve a mobilização das capacidades necessárias.

Após a análise de cada capacidade de linguagem, apresentaremos um quadro síntese inspirado no quadro de escala de cores apresentado por Rocha (2014). Assim, traremos em uma coluna as capacidades de linguagem analisadas e, nas outras, as produções iniciais e finais de cada grupo. Atribuiremos cores a mobilização de cada capacidade dos alunos em uma escala de cores mais escuras à mais claras. Assim, teremos: i) preto - desenvolvimento significativo; ii) cinza escuro - desenvolvimento parcial; iii) cinza claro - pouco desenvolvimento; iv) branco - sem desenvolvimento, como veremos no quadro abaixo: 
Quadro 17: Desenvolvimento das capacidades dos alunos - Escala de cores

\begin{tabular}{|c|c|c|c|}
\hline $\begin{array}{c}\text { Mobilização } \\
\text { significativa }\end{array}$ & $\begin{array}{c}\text { Mobilização } \\
\text { Parcial }\end{array}$ & Pouca mobilização & Sem mobilização \\
\hline & & & \\
\hline
\end{tabular}

Passaremos, neste momento, às análises das produções (iniciais e finais) da turma A.

\section{Análise das produções dos tutoriais em vídeos dos alunos - Turma A}

\begin{tabular}{|c|l|l|l|}
\hline Grupo & Integrantes & Produção inicial & Produção final \\
\hline 1 & Luna, Renan, Bernardo & $\begin{array}{l}\text { Tuto de lait au chocolat } \\
(01: 09 \text { min })\end{array}$ & $\begin{array}{l}\text { Tuto Pomo d'or (2:07 } \\
\text { min })\end{array}$ \\
\hline 2 & Sofia, Leo, Nina & $\begin{array}{l}\text { Tuto tarte au bis }(01: 53 \\
\text { min })\end{array}$ & $\begin{array}{l}\text { Tuto comme (sic) faire } \\
\text { une poudre de couleur } \\
(01: 27 \text { min })\end{array}$ \\
\hline 3 & Beatriz, Julia, Arthur & La Brigadero (01:44 min) & Tye Dye (01:58 min) \\
\hline
\end{tabular}

Iniciando pelo desenvolvimento das capacidades de ação, ou seja, pelas capacidades mobilizadas em relação ao contexto de produção do gênero tutorial em vídeos, na primeira produção do grupo 1, observamos que a implicação do enunciador se deu pelos dêiticos de pessoa, no momento em que os eles apresentam o resultado final do que foi ensinado, com a aparição dos enunciadores em cena e, no final do vídeo, em que aparecem os nomes dos integrantes do grupo. No entanto, na segunda produção, não perdendo de vista o destinatário (colegas da turma), percebemos que houve uma maior implicação: o tutorial não foi feito por uma pessoa desconhecida. Os alunos se apresentam e, com isso, compreendemos que ele foi realizado por Luna e Renan, colegas de classe dos destinatários. Isso pode ser verificado também na aparição dos alunos logo no início dos vídeos. 


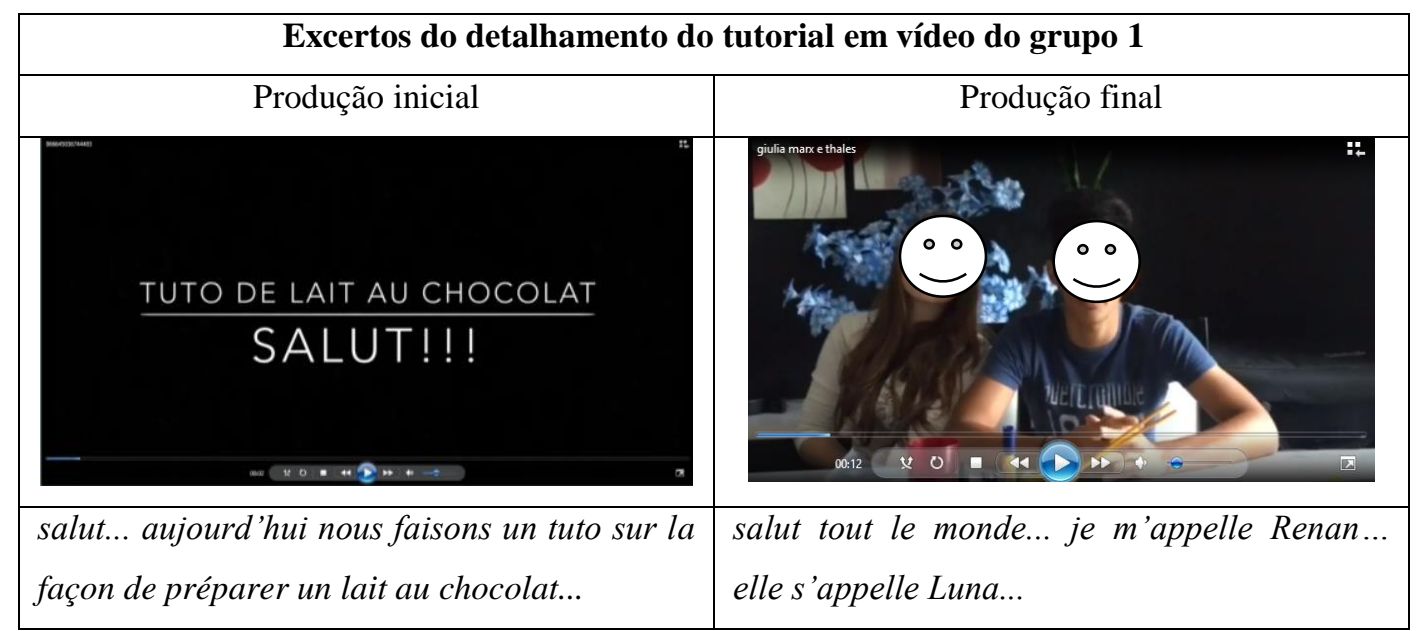

Na produção inicial do grupo 2, os alunos iniciam o vídeo com os ingredientes e passam diretamente ao modo de preparo. Não conseguimos perceber assim quem está por traz do texto, pois não há implicação dos enunciadores. Apesar de termos exemplos de tutoriais em vídeos mais semelhantes ao manual instrucional, na sequência didática, demos ênfase à apresentação do produtor do vídeo e, por essa razão, a implicação do enunciador era uma operação esperada nas produções. $\mathrm{Na}$ segunda produção, ao contrário, percebemos que esta implicação ocorreu por meio do texto verbal e não verbal:

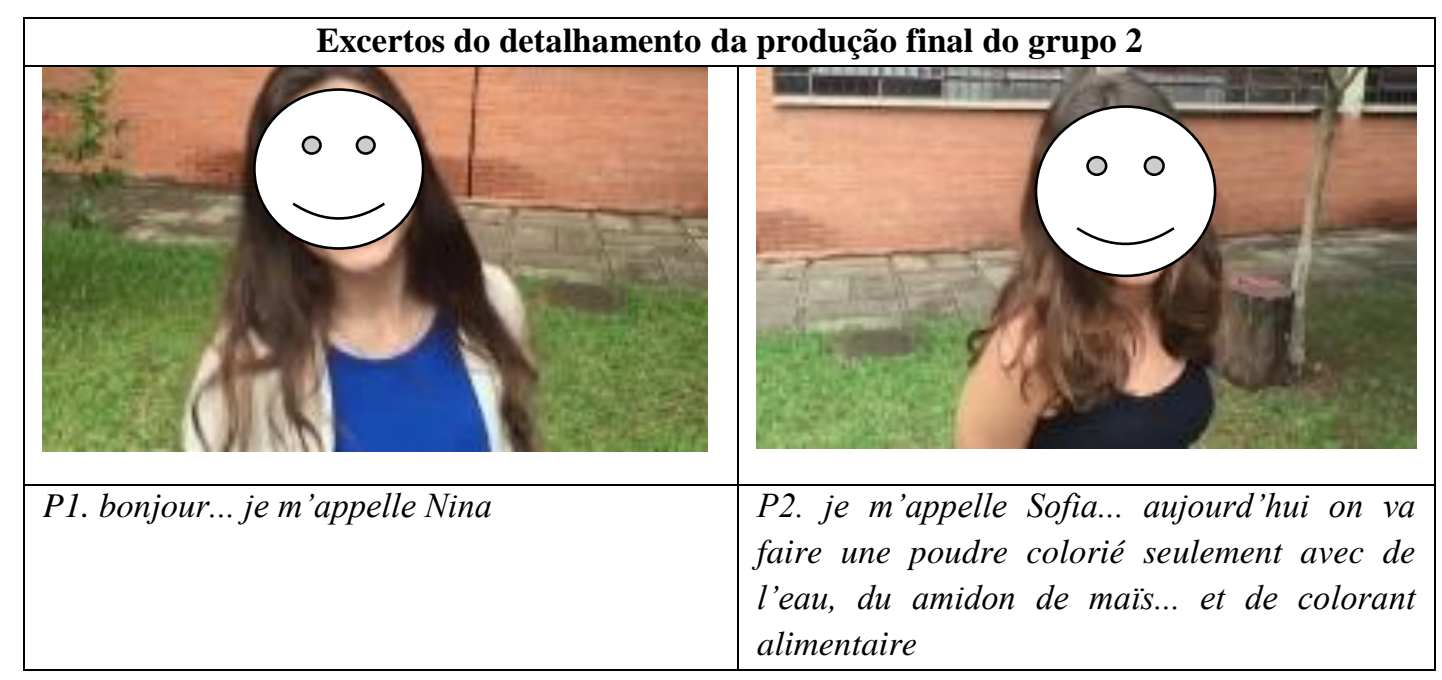

Como vimos, há a apresentação da aluna no plano verbal, ao mesmo tempo que vemos sua imagem no vídeo.

No grupo 3, por sua vez, observamos que os enunciadores se mostraram implicados tanto na primeira produção como na segunda: 


\begin{tabular}{|l|l|}
\hline \multicolumn{3}{|c|}{ Excertos do detalhamento do tutorial em vídeo do grupo 3} \\
\hline \multicolumn{2}{|c|}{ Produção inicial }
\end{tabular}

Em relação ao destinatário e os objetivos do vídeo, percebemos que houve desenvolvimento nos três grupos observados. No trecho abaixo, trouxemos os temas escolhidos pelos alunos para realizar as produções:

\begin{tabular}{|l|l|l|}
\hline \multicolumn{2}{|c|}{ Títulos dos vídeos dos alunos } \\
\hline & \multicolumn{1}{|c|}{ Produções iniciais } & \multicolumn{1}{c|}{ Produções finais } \\
\hline Grupo 1 & Tuto lait au chocolat & Tuto Pomo d'or \\
\hline Grupo 2 & Tuto tarte au bis & $\begin{array}{l}\text { Tuto comme (sic) faire une poudre de } \\
\text { couleur }\end{array}$ \\
\hline Grupo 3 & La brigadero & Tie Dye \\
\hline
\end{tabular}

Ao trabalhar a SD em sala, salientamos a importância de não se perder de vista o destinatário na produção de um texto, pois ele é fundamental no que se refere aos objetivos que se pretende alcançar (no caso dos tutoriais, ensinar algo a alguém, agradar ao público ou conquistar seguidores). Nesse sentido, uma vez que o destinatário dos alunos eram seus colegas de classe inseridos na faixa etária de quinze à dezesseis anos, acreditamos que a escolha do tema das produções finais atingiu o público destinado. Nas produções iniciais, a totalidade das produções é relacionada à culinária e, na segunda, os temas voltaram-se para o centro de interesse do público: um objeto que aparece nos filmes do Harry Potter, um pó colorido da festa das cores e uma camisa customizada no estilo Tie Dye.

Quanto ao objetivo ensinar algo a alguém, ainda que nas produções iniciais do grupo 1 e 2 o objetivo tenha sido atingido, percebemos, nas produções finais, uma maior preocupação nas orientações de como se fazer algo. Isso foi verificado, por exemplo, 
pela maior mobilização de mecanismos de conexão e pela organização dos conteúdos temáticos como discutiremos mais à frente. Na produção do grupo 3, observamos que os alunos tiveram dificuldade de construir um texto coerente, o que dificultou atingir plenamente os objetivos do gênero. Todavia, na produção final, apresentaram um texto organizado e coerente deixando o objetivo "ensinar algo a alguém” evidente.

Abaixo, trouxemos o quadro síntese da discussão sobre as capacidades de ação da turma A.

Quadro 18: Quadro síntese do desenvolvimento da capacidade de ação - Turma A

\begin{tabular}{||l||l|l||l|l||l|l||}
\hline \multirow{2}{*}{ CAPACIDADES DE AÇÃo } & \multicolumn{2}{|c|}{ Grupo 1 } & \multicolumn{2}{|c||}{ Grupo 2 } & \multicolumn{2}{|c|}{ Grupo 3 } \\
\cline { 2 - 7 } & PI & PF & PI & PF & PI & PF \\
\hline \hline Enunciador & & & & & & \\
\hline Destinatário & & & & & & \\
\hline Objetivo & & & & & & \\
\hline
\end{tabular}

Passemos agora para a análise das capacidades discursivas que se referem à organização temático-representacional do texto.

Nos três grupos observados, vimos um significativo desenvolvimento nas capacidades discursivas. Os temas escolhidos foram mais elaborados, como verificamos anteriormente, e observamos uma maior mobilização do plano global dos conteúdos temáticos na totalidade dos grupos. Os quadros abaixo mostram os conteúdos temáticos mobilizados nas produções iniciais e finais dos três grupos: 


\begin{tabular}{|l|l|}
\hline \multicolumn{2}{|c|}{ Plano global dos conteúdos temáticos mobilizados nas produções do grupo 1 } \\
\hline \multicolumn{1}{|c|}{ Produção inicial } & \multicolumn{1}{c|}{ Produção final } \\
\hline a) título; & a) título; \\
b) saudação; & b) saudação; \\
c) ingredientes; & c) apresentação dos participantes presentes no vídeo; \\
d) modo de preparo; & d) apresentação do que será feito; \\
e) resultado final; & e) função daquilo que está sendo ensinado; \\
f) despedida; & f) materiais utilizados; \\
& g) orientação sobre como fazer; \\
& h) apreciação sobre o que foi ensinado; \\
& h) resultado final; \\
& i) agradecimentos. \\
\hline
\end{tabular}

\begin{tabular}{|l|l|}
\hline \multicolumn{2}{|c|}{ Plano global dos conteúdos temáticos mobilizados nas produções do grupo 2} \\
\hline Produção inicial & \multicolumn{1}{c|}{ Produção final } \\
\hline a) título; & a) título; \\
b) ingredientes; & b) saudação; \\
c) modo de preparo; & c) apresentação dos participantes presentes no vídeo; \\
d) resultado final; & d) apresentação do que será feito; \\
& e) materiais utilizados \\
& f) apreciação sobre o que será ensinado; \\
& g) orientação sobre como fazer; \\
& h) resultado final; \\
& i) nomes dos integrantes do grupo. \\
\hline
\end{tabular}

\begin{tabular}{|c|c|}
\hline \multicolumn{2}{|c|}{ Plano global dos conteúdos temáticos mobilizados nas produções do grupo 3} \\
\hline Produção inicial & Produção final \\
\hline $\begin{array}{l}\text { a) apresentação dos participantes presentes no } \\
\text { vídeo; } \\
\text { b) apresentação do que será feito; } \\
\text { b) ingredientes; } \\
\text { c) modo de preparo. }\end{array}$ & $\begin{array}{l}\text { a) saudação } \\
\text { b) apresentação do que será feito } \\
\text { c) material necessário; } \\
\text { d) apreciação sobre o que será ensinado; } \\
\text { e) orientação de como deve ser feito; } \\
\text { f) despedida; } \\
\text { g) resultado final; } \\
\text { h) despedida (texto escrito); } \\
\text { i) nomes dos integrantes do grupo. }\end{array}$ \\
\hline
\end{tabular}

Em relação ao tipo de discurso, especificamente o discurso interativo presente nos vídeos tutoriais, verificamos também um desenvolvimento, uma vez que, nas 
produções finais observadas, percebemos uma maior ocorrência de dêiticos temporais, espaciais e de pessoa. Nos tipos de sequência, por sua vez, verificamos que tanto nas produções iniciais como finais dos três grupos, tivemos sequências descritivas de ações. Em relação à macro sequência dialogal, com exceção da primeira produção do grupo 2 , a totalidade dos grupos apresentaram-na em suas produções. Na produção final do grupo 2, além das sequências descritivas de ações, observamos a ocorrência de um efeito argumentativo global (Melão, 2014) que têm como objetivo persuadir o interlocutor a seguir o tutorial ou mostrar que ele é interessante:

\begin{tabular}{|l|}
\hline \multicolumn{1}{|c|}{ Excerto da transcrição da produção final do tutorial do grupo 2} \\
\hline c'est super pour le faire parce que c'est amusant et comme le colorant est comestible... il n'y a pas de \\
problème si elle tombe dans le bouche ou dans l'oeil... et ne tache pas les vêtements (sic)
\end{tabular}

Nos grupos 1 e 3, por outro lado, observamos uma tentativa de causar esse efeito argumentativo global através de modalizações e acreditamos que, apesar de não terem conseguido mobilizar a operação de forma plena, a tentativa é bastante significativa considerando o nível de língua dos alunos. Discorreremos melhor sobre isso na seção de modalizações.

No que concerne aos tipos de representações que se inserem no quadro da organização temático-representacional não verbal, percebemos que todos os grupos demonstraram, tanto na produção inicial quanto final, ter certo domínio dos aspectos não verbais do texto: nas imagens de ação (em que o participante age sobre determinada pessoa ou objeto) e nas representações conceituais (ao dar ênfase nos materiais ou no resultado final dos objetos). No exemplo abaixo, temos a imagem do tutorial do grupo 1 , em que os alunos apresentam as representações conceituais.

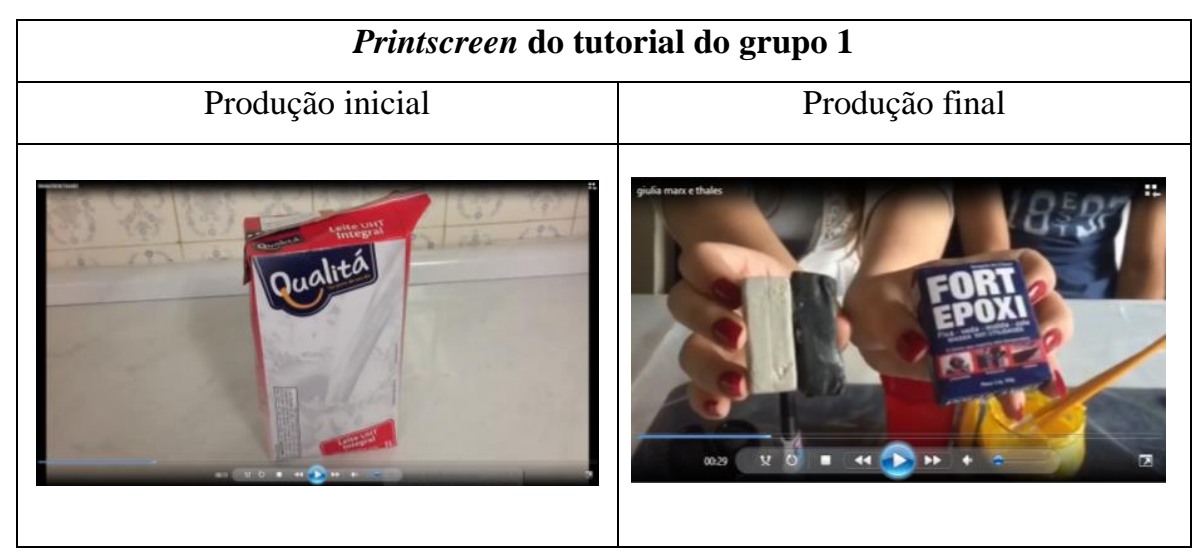


Apresentamos, assim, o quadro síntese das capacidades discursivas:

Quadro 18: Quadro síntese do desenvolvimento das capacidades discursivas Turma A

\begin{tabular}{|c|c|c|c|c|c|c|c|c|}
\hline \multirow{2}{*}{\multicolumn{3}{|c|}{ CAPACIDADES DISCURSIVAS }} & \multicolumn{2}{|c|}{ Grupo 1} & \multicolumn{2}{|c|}{ Grupo 2} & \multicolumn{2}{|c|}{ Grupo 3} \\
\hline & & & PI & $\mathrm{PF}$ & PI & $\mathrm{PF}$ & PI & $\mathrm{PF}$ \\
\hline \multirow{6}{*}{$\begin{array}{l}\text { Organiza } \\
\text { ção } \\
\text { temático- } \\
\text { represen- } \\
\text { tacional }\end{array}$} & \multicolumn{2}{|c|}{ Plano global dos $\mathrm{CTs}^{26}$} & & & & & & \\
\hline & \multicolumn{2}{|c|}{ Tipos de discurso } & & & & & & \\
\hline & \multirow{3}{*}{$\begin{array}{l}\text { Tipos de } \\
\text { sequên- } \\
\text { cia }\end{array}$} & Descritiva de ações & & & & & & \\
\hline & & Macro sequência dialogal & & & & & & \\
\hline & & Efeito argumentativo global & & & & & & \\
\hline & \multicolumn{2}{|c|}{ Tipos de Representações } & & & & & & \\
\hline
\end{tabular}

Passaremos agora para as capacidades linguístico-discursivas que se referem às operações de linguagem esperadas na organização estrutural (modo como o texto é apresentado em sua composição) e organização interacional (modos de interação entre o autor e o leitor, entre os elementos semióticos no texto e entre os participantes representados e os participantes interativos).

Como discorremos anteriormente, os alunos demostraram certo domínio dos aspectos não verbais do texto, tanto nas produções iniciais como finais. Isso pôde ser verificado também na categoria valor da informação, que, como vimos no modelo didático do gênero tutorial em vídeos, pode ser dividida em imagens centradas (quando se quer dar ênfase à um objeto específico) e polarizadas, quando não há um grau de importância entre os objetos presentes em cena. Nessa categoria, observamos que os alunos apresentaram de forma coerente, ora imagens centradas, ora polarizadas.

Passando para os mecanismos de textualização, mais precisamente os mecanismos de conexão, observamos que o grupo 1 apresentou um desenvolvimento bastante significativo na produção final, o que não ocorreu nos grupos 2 e 3 .

\footnotetext{
${ }^{26}$ Conteúdos temáticos.
} 


\begin{tabular}{|l|l|}
\hline \multicolumn{2}{|c|}{ Mecanismos de conexão presentes nas produções do grupo 1 } \\
\hline \multicolumn{1}{|c|}{ Produção inicial } & \multicolumn{1}{c|}{ Produção final } \\
\hline a) d'abord; & a) d'abord; \\
b) alors; & b) et; \\
c) enfin; & c) premièrement; \\
d) et. & d) ensuite; \\
& e) après; \\
& f) maintenant; \\
& g) pour finir \\
\hline
\end{tabular}

\begin{tabular}{|c|c|}
\hline \multicolumn{2}{|c|}{ Mecanismos de conexão presentes nas produções do grupo 2} \\
\hline Produção inicial & Produção final \\
\hline a) enfin & a) pour finir \\
\hline
\end{tabular}

\begin{tabular}{|c|c|}
\hline \multicolumn{2}{|c|}{ Mecanismos de conexão presentes nas produções do grupo 3 } \\
\hline Produção inicial & Produção final \\
\hline & g) pour finir \\
\hline
\end{tabular}

Quanto à coesão verbal, nas duas produções do grupo 1, observamos a presença do presente, futuro próximo e imperativo com oscilação entre o "vous", "nous" e "tu", o que é aceitável, uma vez que nos tutoriais observados no modelo também encontramos essa oscilação pela informalidade do gênero e por ser um gênero oral como podemos ver no quadro abaixo:

\begin{tabular}{|c|c|}
\hline \multicolumn{2}{|c|}{ Excertos das produções do grupo 1} \\
\hline Produção inicial & Produção final \\
\hline $\begin{array}{l}\text { aujourd'hui nous faisons } \\
\text { pour cela... nous allons besoin } \\
\text { Appliquez... } \\
\text { Ajoutez... } \\
\text { nous mélangeons... } \\
\text { bois votre lait au chocolat... }\end{array}$ & $\begin{array}{l}\text { premièrement nous allons faire une petite bolle de } \\
\text { durepox.... } \\
\text { nous allons dessiner un ailes } \\
\text { passez une couche de peinture d'or sur les petits } \\
\text { bolles et sur les ailes... pour finir... fais une } \\
\text { marque... }\end{array}$ \\
\hline
\end{tabular}

Acreditamos que a construção equivocada, com o uso da segunda pessoa do singular em "bois votre..." et "fais une marque...", poderia ser justificada também por serem verbos irregulares na língua francesa e os alunos ainda estarem aprendendo esses verbos, pois se observarmos os exemplos, são as únicas ocorrências na segunda pessoa 
do singular. Além disso, nas duas produções desse mesmo grupo, observamos os efeitos de aceleração que têm como finalidade deixar o vídeo mais curto e, como destacamos no nosso modelo didático, consideramos como um mecanismo de textualização que tem como função a progressão textual.

Algo semelhante ocorreu com as produções do grupo dois: na primeira produção tivemos o uso do imperativo e no infinitivo.

\begin{tabular}{|l|l|}
\hline \multicolumn{2}{|c|}{ Excertos das produções do grupo 2 } \\
\hline \multicolumn{1}{|c|}{ Produção inicial } & \multicolumn{1}{c|}{ Produção final } \\
\hline$\underline{\text { ajoutez une cuillère }}$ & aujourd'hui on va faire \\
$\underline{\text { utilisez cette masse }}$ & $\underline{\text { mettre l'amidon à bol... }}$ \\
$\underline{\text { battre deux blancs }}$ & $\underline{\text { mélangez de l'eau coloré }}$ \\
& $\underline{\text { laisse (sic) sécher pendant deux jours }}$ \\
\hline
\end{tabular}

No entanto, mais uma vez, acreditamos que o uso do "battre" no infinitivo se deu por ser um verbo irregular. Na segunda produção, observamos a presença do futuro próximo e imperativo, com a mesma ocorrência do verbo irregular "mettre". O nível de língua real dos alunos, que passamos a conhecer apenas quando começamos a sequência didática, parece ter sido o responsável por esses erros linguísticos. De qualquer forma, isso não invalida a aplicação de nossa sequência didática, já que os alunos mostraram formas corretas dos verbos na maior parte de suas produções.

Na produção inicial do grupo 3, observamos a presença do futuro próximo para apresentar o que será ensinado e os verbos no infinitivo para a explicação do que será feito. No entanto, podemos perceber que o texto está bastante incoerente. Supomos que os alunos utilizaram algum mecanismo de tradução automática. Na produção final, por sua vez, observamos que o texto é coerente e os alunos conseguiram fazer uso dos verbos no futuro próximo, no imperativo e no passado composto. Esse fato em si, já mostra um certo desenvolvimento dos alunos, que se sentiram capazes de produzirem sozinhos os seus textos, depois de realizada a sequência didática em aula. 


\begin{tabular}{|l|l|}
\hline \multicolumn{2}{|c|}{ Excertos das produções do grupo 3 } \\
\hline \multicolumn{1}{|c|}{ Produção inicial } & \multicolumn{1}{c|}{ Produção final } \\
\hline Nous allons préparer la brigadeiro & $\begin{array}{l}\text { P3. aujourd'hui on va faire un t-shirt tie dye } \\
\text { P1. vous avez besoin d'un t-shirt blanc... trois } \\
\text { élastiques... trois( ) (eau) et alcool }\end{array}$ \\
$\begin{array}{l}\text { Préparation Lieu dans un lait condensé de } \\
\text { poudre de chocolat cuire à eu moyen en remuent } \\
\text { constamment avec une cuillère en bois cuire } \\
\text { jusqu'à ce que le brigadier commencer à se délite } \\
\text { de la cassarole Puis prendre le réfrigérateur }\end{array}$ & \\
\hline
\end{tabular}

$\mathrm{Na}$ coesão nominal, observamos mais especificamente os artigos partitivos e advérbios de quantidade/medida uma vez que foi um aspecto trabalhado durante a sequência didática ${ }^{27}$. Na primeira produção do grupo 1, tanto os advérbios de quantidade quanto os artigos partitivos foram ausentes, o que, no contexto utilizado pelos alunos, é admissível, pois a língua francesa admite a não utilização dos partitivos quando se trata de uma lista. Todavia, supomos que os alunos ainda não tenham uma sensibilização da língua a ponto de ter feito a listagem sem os partitivos de forma consciente de que é correto. Na segunda produção, no entanto, percebemos uma ocorrência dos partitivos com o "de l'eau". Apesar de os alunos terem utilizado "le colle" et "de peiture doré", acreditamos que o "de l'eau" foi bastante significativo, uma vez que, durante a sequência, trabalhamos os partitivos juntamente com os alimentos e talvez não tenha ficado claro que o uso desses artigos podem ser estendidos a objetos, sentimentos etc.

\begin{tabular}{|l|l|}
\hline \multicolumn{2}{|c|}{ Excertos das produções do grupo 1 } \\
\hline \multicolumn{1}{|c|}{ Produção inicial } & \multicolumn{1}{|c|}{ Produção final } \\
\hline $\begin{array}{l}|c| \\
\text { pó }(\text { sic }) \ldots \text { tasses... }\end{array}$ & $\begin{array}{l}\text { P1. le colle... super bonder... } \\
\text { P1. de peiture doré... } \\
\text { P1. de l'eau }\end{array}$ \\
\hline
\end{tabular}

O grupo 2 mostrou que já tinha essa capacidade linguístico-discursiva desenvolvida com apresentação da quantidade exata de alguma coisa precedida de "de" na produção inicial e, na produção final, a utilização dos partitivos.

\footnotetext{
27 Como salientamos na seção sobre a elaboração da sequência didática, adaptamos alguns conteúdos previstos na sequência aos conteúdos que deveriam ser trabalhados no terceiro trimestre da turma. Por essa razão, incluímos, por exemplo, uma atividade sobre os artigos partitivos e sobre os advérbios de quantidade.
} 


\begin{tabular}{|l|l|}
\hline \multicolumn{2}{|c|}{ Excertos das produções do grupo 2 } \\
\hline \multicolumn{1}{|c|}{ Produção inicial } & \multicolumn{1}{|c|}{ Produção final } \\
\hline $\begin{array}{l}\text { ajoutez une cuillère à soupe de beurre fondu et une } \\
\text { cuillère à soupe de eau }\end{array}$ & $\begin{array}{l}\text { on va faire une poudre colorié seulement avec de } \\
\text { l'eau, du amidon de maïs... et de colorant } \\
\text { alimentaire }\end{array}$ \\
\hline
\end{tabular}

Por fim, para finalizar os mecanismos de coesão nominal, temos o grupo 3. Como ressaltado anteriormente, ainda que o grupo 3 tenha apresentado alguns pontos de forma correta, como no exemplo, os partitivos "de la margarine" e "de la poudre", o texto, de um modo geral, mostra-se incoerente. Contudo, na produção final, o grupo apresenta o uso do partitivo e, o mais importante, um texto com uma organização coerente.

\begin{tabular}{|l|l|}
\hline \multicolumn{2}{|c|}{ Excertos das produções do grupo 2 } \\
\hline \multicolumn{1}{|c|}{ Produção inicial } & \multicolumn{1}{|c|}{ Produção final } \\
\hline $\begin{array}{l}\text { Lieu dans un lait condensé de cassarole profonde, } \\
\text { et de la margarine et de la poudre }\end{array}$ & $\begin{array}{l}\text { P3. prendre le t-shirt blanc ( ) avec de l'alcool et } \\
\text { de l'eau }\end{array}$ \\
\hline
\end{tabular}

Quanto às capacidades linguístico-discursivas, no que se referem às vozes, nas produções iniciais e finais dos 3 grupos, tivemos as vozes dos enunciadores e dos destinatários observáveis pelos dêiticos de pessoa presentes no texto. Além disso, na produção final do grupo 1, tivemos uma ocorrência de índice não verbal de inserção de vozes, como a imagem do personagem Harry Potter projetada em um momento do vídeo e que dialoga com o tema da produção dos alunos: um objeto presente nos filmes do Harry Potter.

Nos três grupos, observamos a ocorrência de mecanismos enunciativos como as modalizações nas produções finais, até então ausentes nas iniciais e acreditamos que foi uma tentativa de trazer o tipo de sequência com efeito argumentativo global (grupo $1 \mathrm{e}$ 3), como discutimos anteriormente. 


\begin{tabular}{|l|l|l|}
\hline & \multicolumn{1}{|c|}{ Excertos das produções finais dos grupos } & \multicolumn{1}{|c|}{ Modalizações } \\
\hline Grupo 1 & $\begin{array}{l}\text { vous pouvez utiliser pour décorer votre maison... les fans de } \\
\text { Harry Potter vont adorer l'idée... }\end{array}$ & Lógica \\
\hline Grupo 2 & $\begin{array}{l}\text { P1. c'est super pour le faire parce que c'est amusant et comme } \\
\text { le colorant est comestible... il n'y a pas de problème si elle } \\
\text { tombe dans le bouche ou dans l'oeil... et ne tache pas les } \\
\text { vêtements }\end{array}$ & Apreciativa \\
\hline Grupo 3 & \begin{tabular}{l} 
P2. le tuto... c'est facile et simple \\
\hline
\end{tabular} & Apreciativa \\
\hline
\end{tabular}

Quanto aos aspectos não verbais, percebemos que os alunos possuíam domínio de certos pontos, entretanto, observamos desenvolvimento no contato de interpelação, no plano fechado em ângulo frontal, categoria em que o participante em cena convida o destinatário a participar do ato semiótico através do olhar, revelando um grau de intimidade e uma aproximação afetiva entre os participantes interativos. Na primeira produção, dos grupos 1 e 2, o contato de interpelação foi ausente na primeira produção, diferentemente da produção final, como podemos constatar no exemplo abaixo:

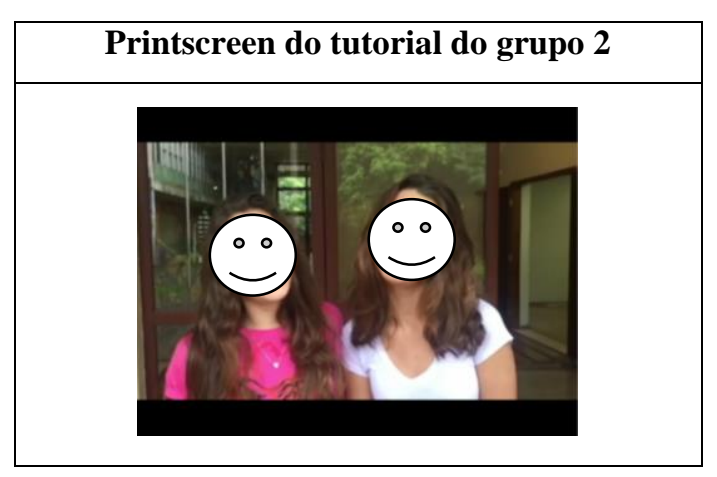

$\mathrm{Na}$ categoria modalidade referente ao cenário do ato comunicativo, observamos que, na primeira produção, os três grupos trouxeram um cenário "caseiro" e na segunda produção, um cenário mais estruturado. Ainda que a produção inicial dos alunos tenha sido abordado o tema culinária, o que justificaria o cenário "caseiro", acreditamos que os alunos tiveram uma preocupação maior, uma vez que, em uma das atividades da sequência, foi explicitado esse aspecto. 


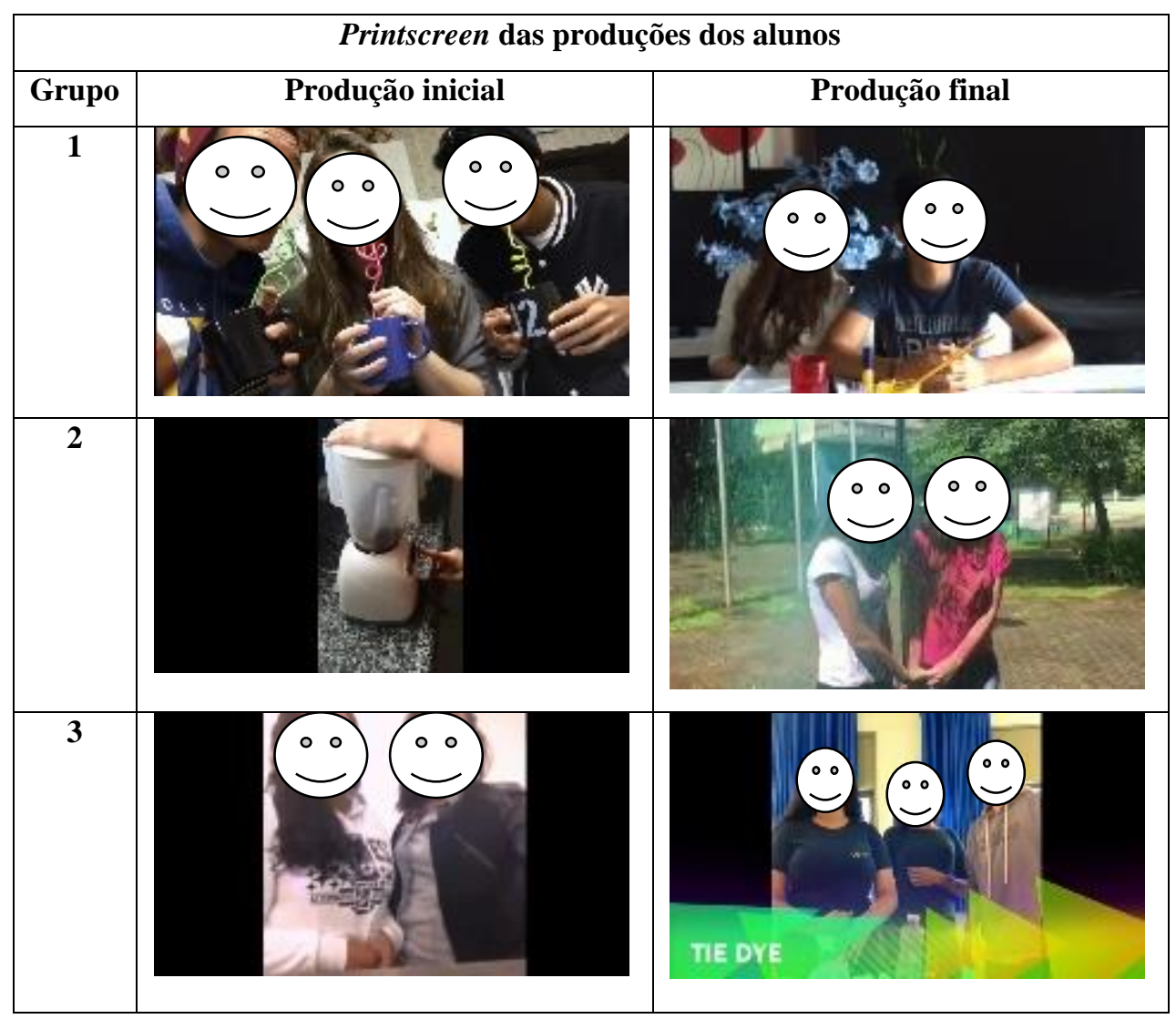

Por fim, a respeito dos efeitos e músicas presentes nas produções, verificamos que, em todas as produções, os alunos se preocuparam em colocar uma música de fundo e efeitos nas trocas de cena, cortes, aceleração etc. Ainda assim, vimos um desenvolvimento, pois nas produções finais, os efeitos foram presentes com mais frequência e, na produção do grupo 2, além da música instrumental de fundo, os alunos apresentaram onomatopeias.

Para finalizar a análise da turma A, sintetizamos em um quadro o desenvolvimento das capacidades linguístico-discursivas. 
Quadro 19: Quadro síntese do desenvolvimento das capacidades linguístico-discursivas

\begin{tabular}{|c|c|c|c|c|c|c|c|}
\hline \multirow{2}{*}{\multicolumn{2}{|c|}{$\begin{array}{c}\text { CAPACIDADES } \\
\text { LINGUÍSTICO-DISCURSIVAS }\end{array}$}} & \multicolumn{2}{|c|}{$\overline{\overline{\text { Grupo } 1}}$} & \multicolumn{2}{|c|}{$\overline{\text { Grupo } 2}$} & \multicolumn{2}{|c|}{$\overline{\text { Grupo } 3}$} \\
\hline & & \multirow[t]{2}{*}{ PI } & \multirow[t]{2}{*}{$\mathrm{PF}$} & \multirow[t]{2}{*}{ PI } & \multirow[t]{2}{*}{$\overline{P F}$} & \multirow[t]{2}{*}{ PI } & \multirow[t]{2}{*}{$\mathrm{PF}$} \\
\hline \multirow{5}{*}{$\begin{array}{l}\text { Organização } \\
\text { estrutural }\end{array}$} & Valor da informação & & & & & & \\
\hline & Conexão & & & & & & \\
\hline & Coesão nominal & & & & & & \\
\hline & Coesão verbal & & & & & & \\
\hline & Efeitos & & & & & & \\
\hline \multirow{6}{*}{$\begin{array}{l}\text { Organização } \\
\text { interacional }\end{array}$} & Vozes & & & & & & \\
\hline & Modalizações & & & & & & \\
\hline & Contato & & & & & & \\
\hline & Distância social & & & & & & \\
\hline & Atitude & & & & & & \\
\hline & Modalidade & & & & & & \\
\hline
\end{tabular}

\section{Análise das produções dos tutoriais em vídeos dos alunos - Turma B}

\begin{tabular}{|c|l|l|l|}
\hline Grupo & Integrantes & Produção inicial & Produção final \\
\hline $1^{28}$ & André & $\begin{array}{l}\text { Comment dessiner au } \\
\text { style manga }(01: 29 \mathrm{~min})\end{array}$ & $\begin{array}{l}\text { Comment dessiner les } \\
\text { yeux au style manga } \\
(04: 17 \text { min) }\end{array}$ \\
\hline 2 & Marina, Bruno & $\begin{array}{l}\text { Comment faire um skate } \\
(01: 44 \text { min })\end{array}$ & $\begin{array}{l}\text { Comment faire “ollie” } \\
(01: 58 \text { min })\end{array}$ \\
\hline 3 & $\begin{array}{l}\text { Bianca, Alice, Gustavo, } \\
\text { César }\end{array}$ & $\begin{array}{l}\text { Tuto gâteau au chocolat } \\
\text { végétarien (04:59 min) }\end{array}$ & $\begin{array}{l}\text { Comment fait (sic) um } \\
\text { crapaud (03:35 min) }\end{array}$ \\
\hline
\end{tabular}

Passaremos agora para a análise das produções da turma $\mathrm{B}$, iniciando pelas capacidades de ação que são responsáveis pela mobilização de representações sobre o contexto de produção. Observamos que, nos três grupos, a implicação dos enunciadores

\footnotetext{
${ }^{28}$ Este aluno optou por fazer as produções individualmente, mas deixamos o termo "grupo" para facilitar a nossa construção textual.
} 
foi observável ora, pelos dêiticos de pessoa, ora pela imagem do enunciador projetada. No grupo 1 e 2, observamos que houve um desenvolvimento uma vez que, na produção inicial, a implicação se deu através dos dêiticos de pessoa e, na final, além dos dêiticos, observamos a implicação por meio da imagem do aluno projetada, como podemos observar no exemplo abaixo:

\begin{tabular}{|l|l|l|}
\hline \multicolumn{3}{|c|}{ Excertos do detalhamento das produções do grupo 3 } \\
\hline \multicolumn{3}{|c|}{ Produção inicial } \\
\hline
\end{tabular}

O grupo 3, no entanto, apresentou as duas formas de implicação, tanto na produção inicial como na final:

\begin{tabular}{|l|l|}
\hline \multicolumn{3}{|c|}{ Excertos do detalhamento das produções do grupo 3 } \\
\hline \multicolumn{3}{|c|}{ Produção inicial } & \\
\hline
\end{tabular}

Passando ao destinatário, percebemos que de um modo geral, os alunos voltaram suas produções para os colegas de sala, isso pode ser observado pelos temas dos tutoriais em vídeo escolhidos pelos alunos: 


\begin{tabular}{|l|l|l|}
\hline \multicolumn{3}{|c|}{ Títulos dos vídeos dos alunos } \\
\hline & \multicolumn{1}{|c|}{ Produções iniciais } & \multicolumn{1}{c|}{ Produções finais } \\
\hline Grupo 1 & Comment dessiner au style manga & $\begin{array}{l}\text { Comment dessiner les yeux au style } \\
\text { manga }\end{array}$ \\
\hline Grupo 2 & Comment faire um skate & Comment faire "ollie” \\
\hline Grupo 3 & Tuto gâteau au chocolat végétarien & Comment fait (sic) um crapaud \\
\hline
\end{tabular}

Apesar de termos discutido anteriormente que o tema culinária pode não ser tão interessante para o público alvo, consideramos que o tema da produção inicial do grupo 3 difere dos temas das produções iniciais da turma A, pois não se trata de uma receita como as outras e sim uma receita que dialoga com as discussões atuais sobre ter uma vida mais saudável e sobre a diminuição do consumo de carne, que poderia ser interessante para o público.

Quanto ao objetivo "ensinar algo a alguém”, observamos que foi atingido nas produções iniciais do grupo 1 e 3, no entanto, percebemos uma maior preocupação em explicar com clareza o que foi feito na produção final e que são observáveis pela organização dos conteúdos temáticos, na coesão verbal etc. Discutiremos mais à frente a respeito desses mecanismos presentes nas produções dos alunos.

Retornando ao objetivo do gênero, percebemos que, diferentemente do que ocorreu nas produções dos grupos 1 e 3 , na produção inicial do grupo 2, o objetivo não foi atingido uma vez que os alunos não deram as instruções de como se fazer um skate: após a apresentação do tema e dos materiais necessários, os alunos se restringiram a mostrar através da imagem a montagem do skate, sem dar explicações. Apesar de encontrarmos nas práticas sociais tutoriais em vídeos exclusivamente não verbais e por mais que os alunos tenham se esforçado em mostrar através dos gestos o "como fazer", o tema era bastante complexo e sentimos que faltou uma explicação para uma melhor compreensão. Além disso, por ser uma atividade de língua francesa, o texto verbal era de extrema importância na produção dos alunos. Na produção final, no entanto, os alunos atingiram o objetivo esperado.

Além disso, nas três produções finais, os alunos apresentaram o objetivo de conquistar seguidores até então ausentes nas produções iniciais: 


\begin{tabular}{|l|l|}
\hline \multicolumn{2}{|c|}{ Excertos das produções finais dos alunos } \\
\hline Grupo 1 & $\begin{array}{l}\text { P1. j'espère que vous aimez la vidéo et n'oublies pas... signez le dessin... signez... } \\
\text { et likez et s'abonnez... à bientôt }\end{array}$ \\
\hline Grupo 2 & $\begin{array}{l}\text { P2. likez notre vidéo... merci beaucoup! } \\
\text { Grupo 3 }\end{array}$ \\
$\begin{array}{l}\text { P1. vous avez-vous apprécié la vidéo? n'as pas l'importance... likez le vidéo de tout } \\
\text { manière... }\end{array}$ \\
\hline
\end{tabular}

Diante do que expusemos, abaixo temos o quadro síntese do desenvolvimento das capacidades de ação da turma B:

Quadro 20: Quadro síntese do desenvolvimento da capacidade de ação - Turma B

\begin{tabular}{|c|c|c|c|c|c|c|}
\hline \multirow{2}{*}{ CAPACIDADES DE AÇÃO } & \multicolumn{2}{|c|}{ Grupo 1} & \multicolumn{2}{|c|}{ Grupo 2} & \multicolumn{2}{|c|}{ Grupo 3} \\
\hline & PI & $\overline{P F}$ & PI & $\overline{P F}$ & PI & $\mathrm{PF}$ \\
\hline Enunciador & & & & & & \\
\hline Destinatário & & & & & & \\
\hline Objetivo & & & & & & \\
\hline
\end{tabular}

Passaremos agora para as capacidades linguístico-discursivas que se referem às operações de linguagem esperadas na organização estrutural (modo como o texto é apresentado em sua composição) e organização interacional (modos de interação entre o autor e o leitor, entre os elementos semióticos no texto e entre os participantes representados e os participantes interativos).

Iniciando pelo plano global dos conteúdos temáticos apresentados nas produções, observamos que, nos três grupos, houve um desenvolvimento na produção final em relação à inicial: 


\begin{tabular}{|l|l|}
\hline \multicolumn{2}{|c|}{ Plano global dos conteúdos temáticos mobilizados nas produções do grupo 1 } \\
\hline \multicolumn{1}{|c|}{ Produção inicial } & \multicolumn{1}{c|}{ Produção final } \\
\hline a) saudação; & a) saudação; \\
b) apresentação do enunciador; & b) apresentação do que será ensinado; \\
c) apresentação do que será ensinado; & c) apreciação do que será feito; \\
d) materiais necessários & d) materiais necessários; \\
e) modo de fazer; & e) modo de fazer; \\
f) resultado final & f) resultado final \\
g) despedida & g) comentário sobre o vídeo; \\
& h) recomendação do que fazer após terminar o que foi \\
& ensinado; \\
& i) convite para "curtir" e "seguir" o enunciador; \\
& j) despedida. \\
\hline
\end{tabular}

\begin{tabular}{|l|l|}
\hline \multicolumn{2}{|c|}{ Plano global dos conteúdos temáticos mobilizados nas produções do grupo 2} \\
\hline \multicolumn{1}{|c|}{ Produção inicial } & \multicolumn{1}{c|}{ Produção final } \\
\hline a) saudação; & a) abertura; \\
b) apresentação dos enunciadores; & b) apresentação dos enunciadores; \\
d) apresentação do que será feito; & d) apresentação do que será feito; \\
f) materiais necessários; & e) apreciação do que será feito; \\
g) modo de fazer; & f) modo de fazer; \\
h) resultado final; & g) convite para "curtir" o vídeo; \\
i) despedida. & h) agradecimento; \\
& i) despedida. \\
& \\
\hline
\end{tabular}




\begin{tabular}{|l|l|}
\hline \multicolumn{2}{|c|}{ Plano global dos conteúdos temáticos mobilizados nas produções do grupo 3 } \\
\hline \multicolumn{1}{|c|}{ Produção inicial } & \multicolumn{1}{c|}{ Produção final } \\
\hline a) saudação; & a) título; \\
b) apresentação do que será ensinado; & b) saudação; \\
c) ingredientes; & c) apresentação do que será feito; \\
d) modo de preparo; & e) modo de fazer; \\
e) resultado final; & f) convite para “curtir” o vídeo; \\
& g) convite para comentar caso o destinatário não tenha \\
& gostado do vídeo; \\
& h) despedida; \\
& i) nomes dos autores do vídeo. \\
\hline
\end{tabular}

Quanto aos tipos de sequência, com exceção da primeira produção do grupo 2, tivemos a sequência descritiva de ações e a macro sequência dialogal nas duas produções. Ademais, de forma semelhante à turma anterior, os grupos 1 e 2 tentaram produzir uma sequência com efeito argumentativo global através de modalizações apreciativas, como discutiremos mais à frente.

Assim como na turma A, percebemos na turma B um certo domínio por parte dos alunos dos aspectos não verbais. Na categoria tipos de representações, percebemos que os alunos apresentaram imagens de ação em que o participante age sobre algo e nas representações conceituais como no exemplo abaixo:

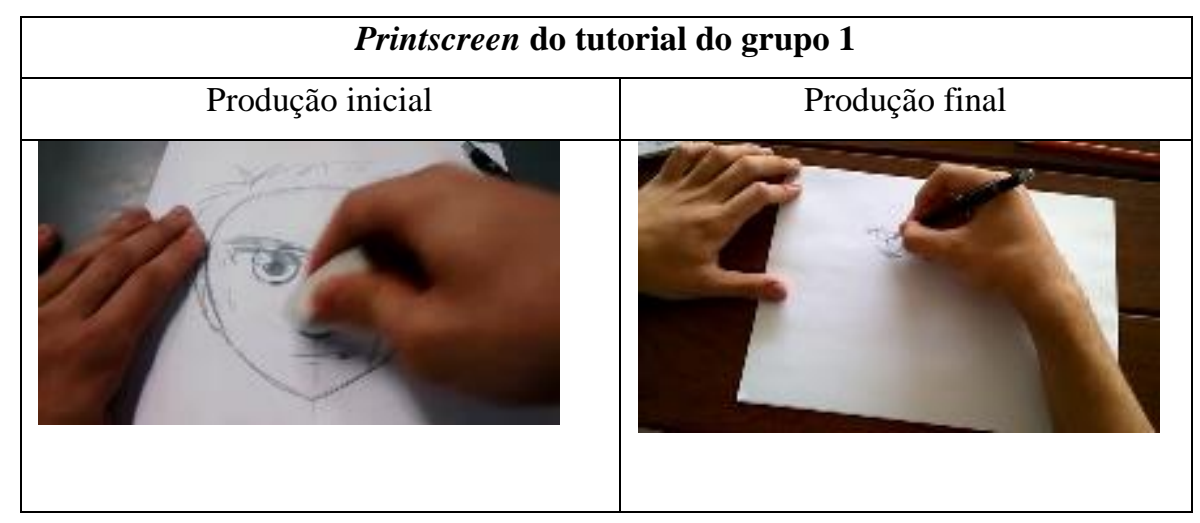

Temos assim, o quadro síntese do desenvolvimento das capacidades discursivas dos alunos: 
Quadro 20: Quadro síntese do desenvolvimento das capacidades discursivas - Turma B

\begin{tabular}{|c|c|c|c|c|c|c|c|c|}
\hline \multirow{2}{*}{\multicolumn{3}{|c|}{ CAPACIDADES DISCURSIVAS }} & \multicolumn{2}{|c|}{ Grupo 1} & \multicolumn{2}{|c|}{ Grupo 2} & \multicolumn{2}{|c|}{ Grupo 3} \\
\hline & & & PI & $\mathrm{PF}$ & PI & $\mathrm{PF}$ & PI & $\mathrm{PF}$ \\
\hline \multirow{6}{*}{$\begin{array}{l}\text { Organiza } \\
\text { ção } \\
\text { temático- } \\
\text { represen- } \\
\text { tacional }\end{array}$} & \multicolumn{2}{|c|}{ Plano global dos $\mathrm{CTs}^{29}$} & & & & & & \\
\hline & \multicolumn{2}{|c|}{ Tipos de discurso } & & & & & & \\
\hline & \multirow{3}{*}{$\begin{array}{l}\text { Tipos de } \\
\text { sequên- } \\
\text { cia }\end{array}$} & Descritiva de ações & & & & & & \\
\hline & & Macro sequência dialogal & & & & & & \\
\hline & & Efeito argumentativo global & & & & & & \\
\hline & \multicolumn{2}{|c|}{ Tipos de Representações } & & & & & & \\
\hline
\end{tabular}

Para finalizar a análise das capacidades de linguagem, passaremos agora para as capacidades linguístico-discursivas. Nessa capacidade, observaremos as operações responsáveis pelo modo como o texto é apresentado em sua composição, a organização estrutural, e no modo de interação entre os participantes interativos e representados, a organização estrutural.

Nos mecanismos de textualização, mais precisamente os mecanismos de conexão, observamos que os três grupos apresentaram um desenvolvimento. Além disso, o grupo 1, apresentou o "voilà" característico da marca da oralidade presente nos tutoriais em vídeo.

\begin{tabular}{|l|l|}
\hline \multicolumn{2}{|c|}{ Mecanismos de conexão presentes nas produções do grupo 1 } \\
\hline \multicolumn{1}{|c|}{ Produção inicial } & \multicolumn{1}{c|}{ Produção final } \\
\hline a) et ; & a) et; \\
b) première (sic); & b) premièrement; \\
c) après; & c) après; \\
d) et. & d) pour finir; \\
& e) voilà. \\
\hline
\end{tabular}

\begin{tabular}{|l|l|}
\hline \multicolumn{2}{|c|}{ Mecanismos de conexão presentes nas produções do grupo 2 } \\
\hline \multicolumn{1}{|c|}{ Produção inicial } & \multicolumn{1}{c|}{ Produção final } \\
\hline Ausente. & a) premièrement; \\
& b) après; \\
& c) dernièrment; \\
& d) et. \\
\hline
\end{tabular}

\footnotetext{
${ }^{29}$ Conteúdos temáticos.
} 


\begin{tabular}{|l|l|}
\hline \multicolumn{2}{|c|}{ Mecanismos de conexão presentes nas produções do grupo 3 } \\
\hline \multicolumn{1}{|c|}{ Produção inicial } & Produção final \\
\hline Ausente. & a) pour finir. \\
\hline
\end{tabular}

Passando para a coesão verbal, observamos também um desenvolvimento nos três grupos observados. Nas produções do grupo 1, tivemos o futuro próximo, o presente e o passado composto. No entanto, observamos que o aluno ainda não dominava o futuro próximo na produção inicial como podemos observar nos exemplos “je vau enseigner..." e "je vous utiliser”, o que foi corrigido na produção final com o "je vais enseigner...". Nas duas produções, o aluno apresentou o presente do verbo "dessiner" com "tu dessins". Acreditamos que tenha sido um caso de hiper correção em que o aluno tenha suposto que o verbo "dessiner" é irregular e que conjugaria como, por exemplo, o verbo "peindre" (je peins, tu peins etc).

\begin{tabular}{|c|c|}
\hline \multicolumn{2}{|c|}{ Excertos das produções do grupo 1} \\
\hline Produção inicial & Produção final \\
\hline $\begin{array}{l}\text { je vau (sic) enseigner comment dessin la visage à } \\
\text { le style manga... } \\
\text { je vous (sic) utiliser une permine... } \\
\text { après tu dessins (sic) le menton... ici... } \\
\text { c'est fini }\end{array}$ & $\begin{array}{l}\text { ahn... aujourd'hui je vais enseigner comment } \\
\text { dessiner les yeux de façon simple et détaillée au } \\
\text { style manga.. } \\
\text { après tu dessins la pupille... ici... } \\
\text { P1. la lumière de l'oeil... elle dépend de... ah.. } \\
\text { comment je dis? j'ai oublié... dépend d'où vient la } \\
\text { lumière... } \\
\text {. et likez et s'abonnez... à bientôt }\end{array}$ \\
\hline
\end{tabular}

O grupo 2, por sua vez, teve um desenvolvimento no uso do imperativo, uma vez que na primeira produção esse tempo verbal foi ausente por razão dos alunos não terem explicado o "como fazer": 


\begin{tabular}{|c|c|}
\hline \multicolumn{2}{|c|}{ Excertos das produções do grupo 2} \\
\hline Produção inicial & Produção final \\
\hline $\begin{array}{l}\text { nous allons vous aprésenter (sic) comment faire un } \\
\text { skate... } \\
\text { c'est fini }\end{array}$ & $\begin{array}{l}\text { P1. (...) on va vous enseigner à comment faire un } \\
\text { manoeuvre sur skate... } \\
\text { P2. premièrement préparez la position avec le } \\
\text { genou serre (sic) le skate... } \\
\text { P2. dernièrement... mettez un pieds sur le skate... } \\
\text { et (...) votre pied... }\end{array}$ \\
\hline
\end{tabular}

Por fim, no grupo três, observamos a presença do futuro próximo e do imperativo. Observamos uma oscilação entre a segunda pessoa do singular "tu" e a segunda do plural "vous" na produção final, mas como dissemos anteriormente, essa oscilação é aceitável, por razão do gênero tutorial em vídeo ser um gênero oral.

\begin{tabular}{|c|c|}
\hline \multicolumn{2}{|c|}{ Excertos das produções do grupo 2} \\
\hline Produção inicial & Produção final \\
\hline $\begin{array}{l}\text { P2. aujourd'hui on va faire } \\
\text { P2. mélangez jusqu'à ce que elle } \\
\text { P2. mettez dans le four pendant quarante } \\
\text { minutes... }\end{array}$ & $\begin{array}{l}\text { P1. aujourd'hui on va faire un crapaud du papier... } \\
\text { P1. pliez un papier rectangulaire au milieu... } \\
\text { P1. fais la même chose d'autre part... } \\
\text { P1. ajoute les pièces }\end{array}$ \\
\hline
\end{tabular}

Quanto aos efeitos de corte e aceleração, considerados como mecanismos de textualização por auxiliarem na progressão textual, observamos que os alunos apresentaram os mecanismos na produção final, até então ausentes na inicial.

No que se refere às vozes, observamos, em todas as produções, as vozes dos enunciadores e dos destinatários, que foram identificados pelos dêiticos de pessoa. Além disso, observamos as vozes de músicas em duas produções e um índice não verbal de inserção de vozes em uma das produções: na produção inicial do grupo 3, observamos a música tema do filme Le fabuleux destin d'Amélie Poulain, justificável por ser uma atividade ligada à língua francesa; na produção final do grupo 1, a música de fundo é uma música japonesa, que dialoga com o tema "dessiner au style manga" uma vez que os desenhos nesses estilos são técnicas de origem japonesa. Por fim, na produção final do grupo 3, observamos a imagem de um sapo projetada, uma vez que o tema do tutorial era "comment faire un crapaud", como podemos observar abaixo: 


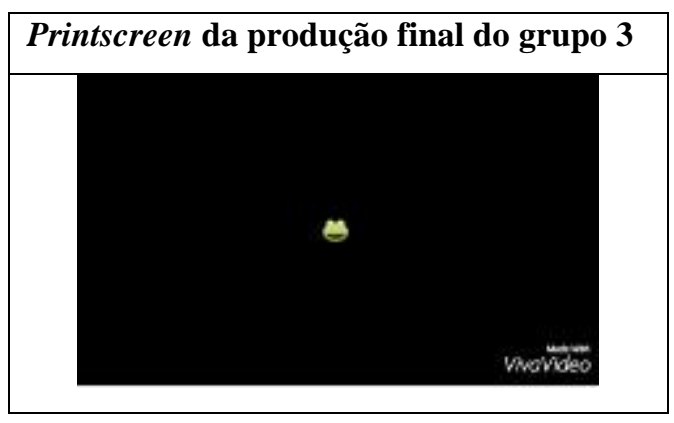

No que se refere às modalizações e retornando à discussão sobre a tentativa dos alunos em causar um efeito argumentativo global (Melão, 2014) para persuadir o destinatário de que o tutorial mostra algo interessante de se fazer, observamos as modalizações apreciativas na produção inicial e final do grupo 1 e na produção final do grupo 2. O grupo 3, no entanto, não apresentou modalizações em nenhuma de suas produções:

\begin{tabular}{|l|l|l|}
\hline \multicolumn{3}{|c|}{ Excertos das produções dos grupos - modalizações apreciativas } \\
\hline Grupo & \multicolumn{1}{|c|}{ Produção inicial } & \multicolumn{1}{c|}{ Produção final } \\
\hline 1 & Pl. c'est très facile mon style... ne difficult (sic)... & P1. le résultat c'est très cool... \\
\hline 2 & - ausente. & $\begin{array}{l}\text { Pl. (...) on va vous enseigner à comment } \\
\text { faire un manoeuvre sur skate... cette } \\
\text { moneuvre un ollie... c'est très facile... }\end{array}$ \\
\hline 3 & - ausente. & - ausente. \\
\hline
\end{tabular}

De forma parecida com a turma A, percebemos que os grupos da turma B apresentaram certo domínio nos aspectos não verbais no texto, mas ainda assim, houve um desenvolvimento. O vídeo tutorial, como discorremos no nosso modelo didático apresenta na categoria contato, o contato de interpelação e de exposição, onde há uma ligação entre o participante em cena e o leitor através do olhar e onde o participante é observado pelo leitor e caracterizado pela ausência de ligação, respectivamente. Observamos um desenvolvimento nos grupos 1 e 2 , uma vez que os grupos haviam apresentado imagens com o contato de exposição na primeira produção e, na segunda, além do contato de exposição, o contato de interpelação: 


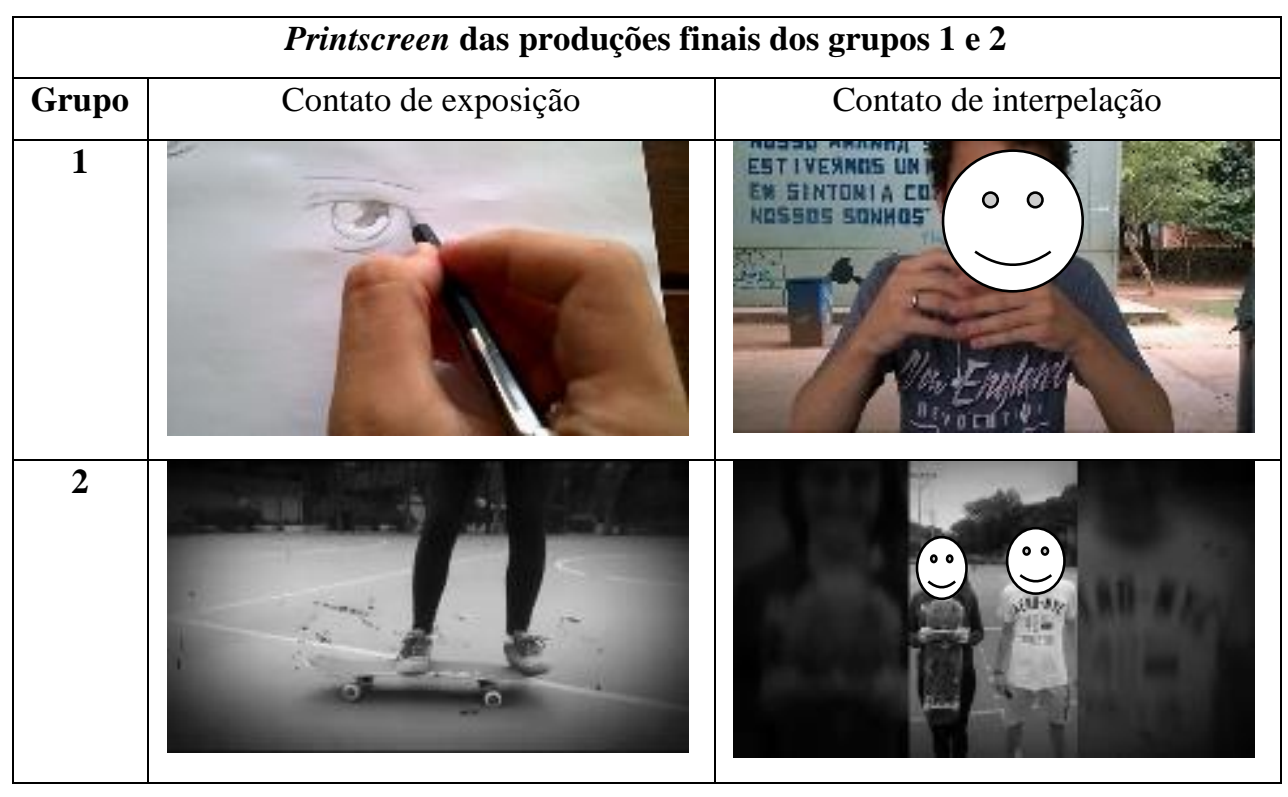

No grupo 3, no entanto, não observamos um desenvolvimento, uma vez que o grupo já havia apresentado os dois tipos de contatos nas duas produções.

Através do contato de interpelação, apresentado nas duas produções do grupo 3 e nas produções finais do grupo 1 e 2, podemos observar duas outras categorias: a distância social (grau de intimidade) e a atitude (aproximação afetiva) observáveis pelos planos de cinema e pelo ângulo em que os participantes se mostram em cena. Observamos assim um desenvolvimento, pois os alunos se mostraram em plano fechado e em ângulo frontal, mostrando um grau de intimidade e uma aproximação afetiva esperada no gênero com o qual trabalhamos.

Por fim, na categoria modalidade, observamos um desenvolvimento nos três grupos observados. Percebemos que os alunos preocuparam-se em apresentar um cenário mais estruturado na produção final, ora por um local visualmente agradável, ora atraves de efeito de emolduramento e de filtros, como podemos observar abaixo: 


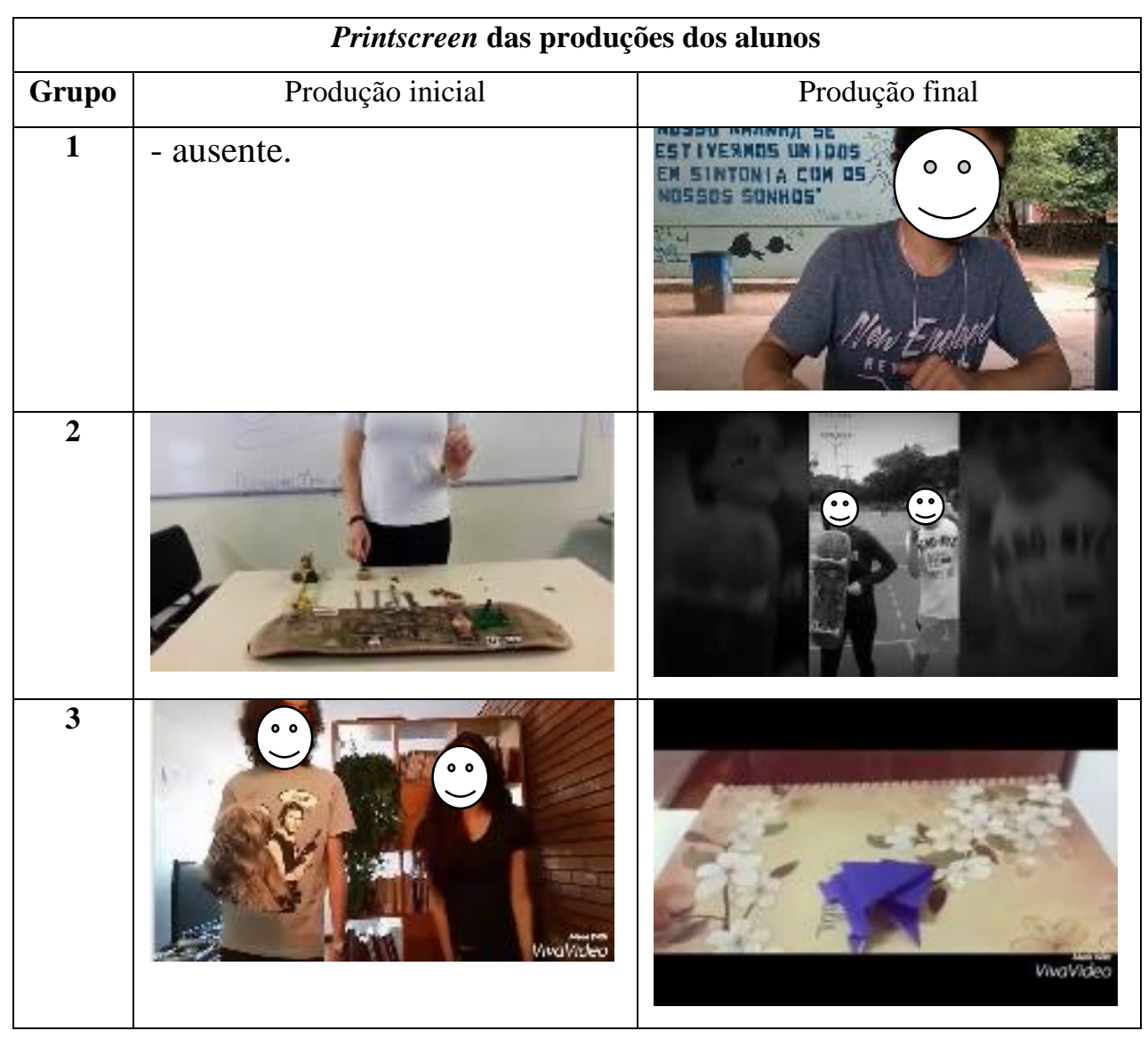

Ademais, percebemos um desenvolvimento bastante significativo em relação aos efeitos presentes nas produções dos grupos 1 e 2 , uma vez que na segunda produção os alunos preocuparam-se em colocar músicas de fundo e efeitos na cena, cortes, até então ausentes na primeira produção. O grupo 3, no entanto, havia apresentado ambos os recursos nas duas produções, mas, de qualquer forma, observamos um aprimoramento em relação a produção inicial.

Para finalizar as análises da turma 3, trazemos assim, o quadro síntese do desenvolvimento das capacidades linguístico-discursivas dos alunos. 
Quadro 21: Quadro síntese do desenvolvimento das capacidades linguístico-discursivas

\begin{tabular}{|c|c|c|c|c|c|c|c|}
\hline \multirow{2}{*}{\multicolumn{2}{|c|}{$\begin{array}{c}\text { CAPACIDADES } \\
\text { LINGUÍSTICO-DISCURSIVAS }\end{array}$}} & \multicolumn{2}{|c|}{ Grupo 1} & \multicolumn{2}{|c|}{$\overline{\text { Grupo } 2}$} & \multicolumn{2}{|c|}{ Grupo 3} \\
\hline & & \multirow[t]{2}{*}{ PI } & \multirow[t]{2}{*}{$\mathrm{PF}$} & \multirow[t]{2}{*}{ PI } & \multirow[t]{2}{*}{$\mathrm{PF}$} & \multirow[t]{2}{*}{ PI } & \multirow[t]{2}{*}{$\mathrm{PF}$} \\
\hline \multirow{5}{*}{$\begin{array}{l}\text { Organização } \\
\text { estrutural }\end{array}$} & Valor da informação & & & & & & \\
\hline & Conexão & & & & & & \\
\hline & Coesão nominal & & & & & & \\
\hline & Coesão verbal & & & & & & \\
\hline & Efeitos & & & & & & \\
\hline \multirow{6}{*}{$\begin{array}{l}\text { Organização } \\
\text { interacional }\end{array}$} & Vozes & & & & & & \\
\hline & Modalizações & & & & & & \\
\hline & Contato & & & & & & \\
\hline & Distância social & & & & & & \\
\hline & Atitude & & & & & & \\
\hline & Modalidade & & & & & & \\
\hline
\end{tabular}

Dedicaremos a nossa próxima seção à discussão das análises e resultados. Para tanto, elaboramos três quadros, divididos por capacidades de linguagem, em que recuperamos o desenvolvimento das duas turmas.

Como mencionamos anteriormente, o quadro foi inspirado no quadro de escala de cores apresentado por Rocha (2014). Assim, apresentamos, em uma coluna, as capacidades de linguagem analisadas e, nas outras, as produções iniciais e finais de cada grupo. Atribuímos as cores à mobilização de cada capacidade dos alunos em uma escala de cores mais escuras à mais claras. Assim, temos: i) preto - desenvolvimento significativo; ii) cinza escuro - desenvolvimento parcial; iii) cinza claro - pouco desenvolvimento; iv) branco - sem desenvolvimento, como vemos no quadro abaixo (já exposto na página 103).

\section{Quadro 22: Desenvolvimento das capacidades dos alunos - Escala de cores}

\begin{tabular}{|c|c|c|c|}
\hline $\begin{array}{c}\text { Mobilização } \\
\text { significativa }\end{array}$ & $\begin{array}{c}\text { Mobilização } \\
\text { parcial }\end{array}$ & Pouca mobilização & Sem mobilização \\
\hline & & & \\
\hline
\end{tabular}


Quadro 23: desenvolvimento das capacidades de ação - Turmas A e B

\begin{tabular}{|c|c|c|c|c|c|c|c|c|c|c|c|c|}
\hline \multirow{3}{*}{$\begin{array}{c}\text { CAPACIDADES } \\
\text { DE AÇÃO }\end{array}$} & \multicolumn{6}{|c|}{ TURMA A } & \multicolumn{6}{|c|}{ TURMA B } \\
\hline & \multicolumn{2}{|c|}{ 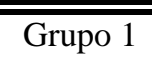 } & \multicolumn{2}{|c|}{$\overline{\text { Grupo } 2}$} & \multicolumn{2}{|c|}{ 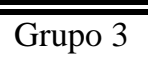 } & \multicolumn{2}{|c|}{ 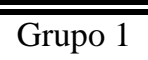 } & \multicolumn{2}{|c|}{ Grupo 2} & \multicolumn{2}{|c|}{ Grupo 3} \\
\hline & PI & $\mathrm{PF}$ & PI & $\mathrm{PF}$ & PI & $\mathrm{PF}$ & PI & $\mathrm{PF}$ & PI & $\mathrm{PF}$ & PI & $\mathrm{PF}$ \\
\hline \multicolumn{13}{|l|}{ Enunciador } \\
\hline \multicolumn{13}{|l|}{ Destinatário } \\
\hline Objetivo & & & & & & & & & & & & \\
\hline
\end{tabular}

Quadro 24: desenvolvimento das capacidades discursivas - Turmas A e B

\begin{tabular}{|c|c|c|c|c|c|c|c|c|c|c|c|c|c|c|}
\hline & \multirow{3}{*}{\multicolumn{2}{|c|}{$\begin{array}{l}\text { CAPACIDADES } \\
\text { DISCURSIVAS }\end{array}$}} & \multicolumn{6}{|c|}{ TURMA A } & \multicolumn{6}{|c|}{ TURMA B } \\
\hline & & & \multicolumn{2}{|c|}{ Grupo 1} & \multicolumn{2}{|c|}{ Grupo 2} & \multicolumn{2}{|c|}{ Grupo 3} & \multicolumn{2}{|c|}{ Grupo 1} & \multicolumn{2}{|c|}{ Grupo 2} & \multicolumn{2}{|c|}{ Grupo 3} \\
\hline & & & PI & $\mathrm{PF}$ & PI & $\mathrm{PF}$ & PI & $\mathrm{PF}$ & PI & $\mathrm{PF}$ & PI & $\mathrm{PF}$ & PI & $\mathrm{PF}$ \\
\hline \multirow{6}{*}{$\begin{array}{l}\text { Organiz } \\
\text { ação } \\
\text { temá- } \\
\text { tico } \\
\text { represen } \\
\text {-tacional }\end{array}$} & \multicolumn{2}{|c|}{ Plano global dos $\mathrm{CTs}^{30}$} & & & & & & & & & & & & \\
\hline & \multicolumn{2}{|c|}{ Tipos de discurso } & & & & & & & & & & & & \\
\hline & \multirow{3}{*}{$\begin{array}{l}\text { Tipos de } \\
\text { se- } \\
\text { quência }\end{array}$} & Descritiva de ações & & & & & & & & & & & & \\
\hline & & Macro sequência dialogal & & & & & & & & & & & & \\
\hline & & Efeito argumentativo global & & & & & & & & & & & & \\
\hline & \multicolumn{2}{|c|}{ Tipos de Representações } & & & & & & & & & & & & \\
\hline
\end{tabular}

\footnotetext{
${ }^{30}$ Conteúdos temáticos.
} 
Quadro 25: desenvolvimento das capacidades linguístico-discursivas

\begin{tabular}{|c|c|c|c|c|c|c|c|c|c|c|c|c|c|}
\hline \multirow{3}{*}{\multicolumn{2}{|c|}{$\begin{array}{l}\text { CAPACIDADES } \\
\text { LINGUÍSTICO- } \\
\text { DISCURSIVAS }\end{array}$}} & \multicolumn{6}{|c|}{ TURMA A } & \multicolumn{6}{|c|}{ TURMA B } \\
\hline & & \multicolumn{2}{|c|}{ "Grupo 1} & \multicolumn{2}{|c|}{ 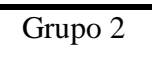 } & \multicolumn{2}{|c|}{ Grupo 3} & \multicolumn{2}{|c|}{ Grupo 1} & \multicolumn{2}{|c|}{ Grupo 2} & \multicolumn{2}{|c|}{ Grupo 3} \\
\hline & & PI & $\mathrm{PF}$ & PI & $\mathrm{PF}$ & PI & $\mathrm{PF}$ & PI & $\mathrm{PF}$ & PI & $\mathrm{PF}$ & PI & $\mathrm{PF}$ \\
\hline \multirow{5}{*}{$\begin{array}{l}\text { Organização } \\
\text { estrutural }\end{array}$} & Valor da inform & & & & & & & & & & & & \\
\hline & Conexão & & & & & & & & & & & & \\
\hline & Coesão nominal & & & & & & & & & & & & \\
\hline & Coesão verbal & & & & & & & & & & & & \\
\hline & Efeitos & & & & & & & & & & & & \\
\hline \multirow{6}{*}{$\begin{array}{l}\text { Organização } \\
\text { interacional }\end{array}$} & Vozes & & & & & & & & & & & & \\
\hline & Modalizações & & & & & & & & & & & & \\
\hline & Contato & & & & & & & & & & & & \\
\hline & Distância social & & & & & & & & & & & & \\
\hline & Atitude & & & & & & & & & & & & \\
\hline & Modalidade & & & & & & & & & & & & \\
\hline
\end{tabular}

São os quadros acima que guiarão a discussão que apresentamos a seguir. 


\section{Discussão das análises e resultados}

Apresentaremos nesta seção a discussão das análises e os resultados obtidos com a aplicação da sequência didática do gênero multimodal tutorial em vídeos. Para realizála, além de sintetizar o que foi observado durante as análises, recuperaremos alguns excertos do diário de bordo e das gravações das conversas dos alunos no momento da organização da produção para melhor compreender como se deu o desenvolvimento dos alunos. Gostaríamos de ter aproveitado melhor as conversas gravadas, no entanto, o aparelho utilizado para a gravação não era de boa qualidade, o que resultou em momentos quase inaudíveis, dificultando a nossa análise. Além disso, tivemos poucos momentos gravados em que os alunos estavam efetivamente em momento de produção textual, pois a maioria dos grupos produziram os vídeos em casa. De qualquer forma, alguns excertos que conseguimos utilizar nos parecem úteis para fornecer mais elementos para a compreeensão da produção textual dos alunos.

Ao analisarmos as produções dos alunos, percebemos que, apesar de ser um gênero com o qual eles estejam habituados em língua materna, a sua produção em língua francesa não foi uma tarefa fácil. Uma das justificativas da dificuldade na sua produção foi o nível de língua dos alunos: ainda que tivessem uma boa compreensão oral, verificada na atividade proposta na nossa SD e, mesmo que as aulas fossem ministradas em francês, nas produções do gênero tutorial em vídeo, o nível linguístico dos alunos ficou bastante evidente: os alunos mostraram estar na fase de "présentation", no aprendizado de frases no presente e no futuro próximo com verbos regulares, ou seja, início do nível A1 do Quadro Europeu Comum de Referência. Além disso, as turmas mostraram-se bastante heterogêneas como pudemos observar na produção inicial.

Ainda assim, podemos constatar que a partir das produções analisadas, os alunos desenvolveram de forma significativa as capacidades de linguagem que permeiam o gênero tutorial em vídeo, tanto no que se refere às capacidades de ação, às discursivas e às linguístico discursivas. Nas capacidades de ação, vimos, na primeira produção, a dificuldade que muitos grupos tiveram na implicação tanto do enunciador como do destinatário. No entanto, a implicação ocorreu de maneira bastante significativa em todas as produções finais, tanto nos aspectos verbais como não verbais.

Com a sequência, pudemos também trabalhar com as representações que os alunos tinham em relação aos objetivos do gênero. No excerto abaixo, temos a conversa 
entre dois alunos no momento da produção inicial. Essa conversa foi gravada no horário de atendimento oferecido pela professora:

\begin{tabular}{|l|}
\hline \multicolumn{1}{|c|}{ Excerto da transcrição da conversa entre André (turma B) e Leo (turma A) } \\
\hline P1. filma só a minha mão \\
P2. mas você não tem que se apresentar antes? você tem que aparecer \\
P1. nos tutoriais que eu vi... não aparece o rosto da pessoa... pelo menos os de desenho
\end{tabular}

Vimos, nesse excerto, que o aluno André estava habituado com o gênero tutorial em vídeos e, para ele, o objetivo principal era o de ensinar algo à alguém, não sendo necessário a sua aparição. Na nossa sequência, procuramos mostrar outros possíveis objetivos que poderiam ser alcançados por meio da produção do gênero. Dito de outra forma, não tínhamos a pretensão de impor um formato a ser seguido, mas sim, mostrar as variações do gênero e como os alunos atingiriam os objetivos pretendidos. Assim, com o contato com outros tutoriais em vídeos durante a sequência, vimos que além de ter aprimorado os mecanismos de textualização para atingir o objetivo de ensinar algo à alguém, percebemos um esforço por parte do aluno em atingir outros objetivos como o de agradar ao público, mostrar que o tutorial é fácil de ser feito etc. A sua produção final trouxe assim, variados recursos multimodais ausentes na primeira produção com diferentes planos na imagem, uma aproximação afetiva com o contato de interpelação (há uma ligação entre o enunciador e o destinatário através do olhar, convidando-o a participar da cena comunicativa), com música etc. enriquecendo a sua produção. Essa (re)construção das representações dos objetivos do gênero ficou evidente nas produções finais de todos os grupos: além de um significativo avanço na mobilização dos conteúdos temáticos, nos mecanismos de textualização e nos mecanismos multimodais, que auxiliaram no objetivo "ensinar algo à alguém", vimos um esforço por parte dos grupos de persuadir o interlocutor a realizar o tutorial através de uma "tentativa" de apresentar um efeito argumentativo global (Melão, 2014) para convencer o interlocutor. Essa tentativa, na maioria dos grupos, ficou restrita à modalizações apreciativas, mas, considerando o nível linguístico dos alunos, foi um desenvolvimento significativo.

Nas capacidades discursivas, vimos um maior desenvolvimento, como salientamos anteriormente, na mobilização dos conteúdos temáticos e no tipo de discurso, mais especificamente o discurso interativo presente nos tutoriais em vídeo. $\mathrm{O}$ desenvolvimento do discurso interativo se deu uma vez que os alunos conseguiram se 
implicar e implicar os destinatários do vídeo tanto em seus aspectos verbais como não verbais.

Passando para as capacidades linguístico-discursivas, percebemos também um desenvolvimento significativo, principalmente nos grupos 1 de ambas as turmas: os alunos da turma A apresentaram na primeira produção um texto incoerente, apesar de podermos observar através das imagens que se tratava do gênero tutorial; na da turma B, os alunos não explicaram verbalmente o passo à passo, o que se justificaria pela complexidade do tema "como montar um skate" que demandava um vocabulário mais específico e pouco apropriado para o nível linguístico dos alunos. Nas produções finais, ambos os grupos trouxeram um texto estruturado com um desenvolvimento nos mecanismos de conexão, na coesão e coerência dos conteúdos temáticos.

Um ponto que nos chamou a atenção nas capacidades linguístico-discursivas foi que alguns grupos trouxeram vozes outras que a do enunciador e do destinatário dos vídeos, tais como vozes através de imagens (índices não verbais de inserção de vozes) e de músicas que dialogavam com o tema do tutorial. Além disso, vimos que os alunos já dominavam certos aspectos da imagem, mas que aprimoraram-nos na segunda produção, ainda que de forma menos significativa.

Observamos, também, que os alunos apresentaram um desenvolvimento em pontos não trabalhados na sequência. Para essa questão, elencamos duas suposições: a) na apresentação da situação, os alunos foram informados de que fariam duas produções, a inicial e a final e, por essa razão, não se aplicaram tanto na primeira produção como na produção final; b) apesar de não ter exercícios de determinado ponto linguístico na sequência, como, por exemplo, o passé composé, ele estava presente nos tutorais das atividades.

Retornando à dificuldade do gênero proposto, vimos que ela iniciou-se na escolha dos temas. No excerto abaixo, temos a conversa de duas alunas no momento da produção final:

Excerto da transcrição das conversas das alunas Sofia e Nina - Assunto: escolha do tema

P1. mas o problema... é muito geral

P2. vamos fazer um tutorial cozinha...

P3. não é muito chato!

Vimos, assim, que ao mesmo tempo que o gênero permitiu uma liberdade na escolha dos temas, ele é, utilizando as palavras da aluna, "muito geral", pois como 
salientamos ao longo desse estudo, podemos encontrar temas de tutoriais em vídeos dos mais variados possíveis nas práticas sociais. Além disso, os alunos não queriam fazer um tema pouco atrativo, o que implicou em variadas etapas na sua produção que não necessariamente estavam ligados ao conteúdo linguístico dos alunos, como podemos observar nos excertos das conversas gravadas das alunas com a professora e do diário de bordo da professora:

Excerto da conversa das alunas Beatriz e Julia com a professora - A escolha do tema

P1. a gente não lembra direito como que faz... a gente tá vendo na internet... a gente vai fazer uma blusa...

P2. a gente vai fazer aquela camiseta sabe? que é tipo assim... só que não é assim...

\begin{tabular}{|l|}
\hline Excerto do diário de bordo da professora - atendimento do dia 03 de novembro \\
\hline "[...] eles preferiram, com exceção do último aluno, escolher algo que eles acham interessante, mesmo \\
sem saber fazer, olhar o tutorial de como se faz, aprender a fazer para depois, ensinar a fazer.
\end{tabular}

Assim, pudemos perceber que, além de ser um gênero complexo em que o foco de atenção é fragmentado a variados pontos na produção (música, efeitos, lugar, elaboração do texto verbal, ensaio, preparação do material etc), ao tentar achar um tema interessante/criativo, muitos grupos optaram por aprender a fazer algo para depois, ensinar. E essa complexidade na etapa de produção (aprender para poder ensinar), ao mesmo tempo, proporcionou o contato dos alunos com outros tutoriais em vídeos. Esse contato com outros tutoriais e não apenas os que foram apresentados na SD, pode poder contribuído para o desenvolvimento de aspectos que não foram diretamente abordados nas aulas.

Vimos, assim, que gênero tornou-se instrumento (VIGOSTSKI, 1997; FRIEDRICH, 2012; SCHNEUWLY; DOLZ, 2013) para o desenvolvimento de capacidades de linguagem, como demonstramos em nossas análises. Com o seu trabalho em sala de aula, ele tornou-se também instrumento para aprender outros tipos de saberes, já que os alunos "aprenderam algo para poder ensinar".

Gostaríamos de salientar um último ponto nessa discussão. Para fazê-lo, traremos um excerto do diário de bordo da professora: 


\begin{tabular}{|l|}
\hline Excerto do diário de bordo da professora - Aula do dia 17 de setembro \\
\hline Dois grupos levaram as atividades em um pendrive e os outros dois, haviam publicado no grupo de \\
francês do Facebook! Achei interessante, pois esse é o objetivo dos tutoriais: publicá-los em alguma rede \\
social e as pessoas que visualizam os vídeos, podem comentar e "curtir" os vídeos. \\
\hline
\end{tabular}

Como observamos neste relato, alguns grupos publicaram os vídeos na rede social Facebook, o que é muito significativo: sabemos que, ao se trabalhar com gêneros textuais em sala de aula, há um desdobramento e o gênero passa a ser não só um instrumento para comunicação, mas também um objeto de ensino-aprendizagem (SCHNEUWLY; DOLZ, 2014). Assim, o aluno se depara em um espaço, nas palavras de Schneuwly e Dolz (2014) de "como se", ou seja, o gênero proporciona uma prática de linguagem, em parte, fictícia. A publicação dos tutoriais em vídeos pelos alunos na rede social Facebook, foi, então, muito significativa, pois embora o gênero não tenha deixado de ser um objeto de ensino-aprendizagem, já que ele foi trabalhado no espaço da escola, ele tornou-se, de forma espontânea (uma vez que não foi pedido aos alunos para se fazer a publicação), mais próximo às práticas sociais. Nesse sentido, podemos dizer que, de gênero presente no mundo social, o tutorial em vídeo entrou como objeto de ensino na escola, e retornou, ao final, para o mundo social. Como isso se deu sem uma demanda formal da professora, permitimo-nos dizer que, nesse caso, tivemos um exemplo de que o gênero funcionou de fato como um instrumento (VIGOSTSKI, 1997; FRIEDRICH, 2012; SCHNEUWLY; DOLZ, 2013) para agir no mundo social, uma vez que os alunos se serviram imediatamente do que tinham acabado de aprender para interagir diretamente com interlocutores reais e fora do espaço "fictício" da escola.

Finalizaremos assim a discussão dos resultados com a imagem do gênero textual tutorial em vídeo produzido pelos alunos e presente nas práticas sociais: 


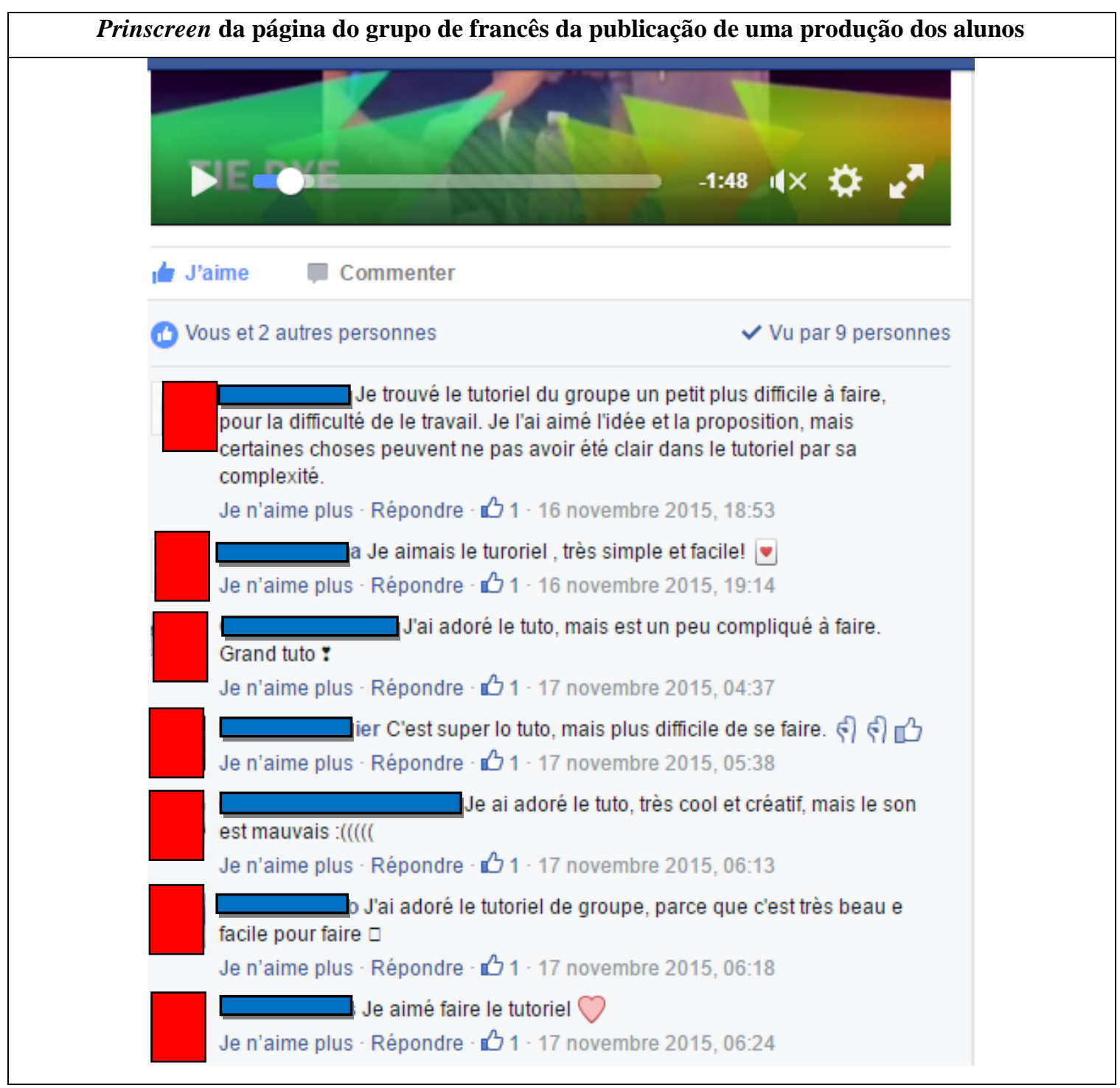




\section{CAPÍTULO V - CONSIDERAÇõES FINAIS}

Com o intuito de trazer contribuições para os estudos sobre o ensinoaprendizagem de línguas com base em gêneros de textos, nos estudos sobre gêneros emergentes na era digital e sobre a multimodalidade, nesta pesquisa, tivemos por objetivo maior estudar o ensino-aprendizagem do francês como língua estrangeira por alunos adolescentes por meio da produção de um gênero multimodal, o tutorial em vídeo. Sendo assim, procuramos verificar se os alunos desenvolvem as capacidades de linguagem através de uma sequência didática (SD) visando o ensino desse gênero. Para tanto, além de analisar as produções textuais dos alunos sobre o gênero tutorial em vídeo, trouxemos alguns excertos do diário de bordo da professora e das gravações das conversas dos alunos para melhor compreensão de como se deu o desenvolvimento das capacidades de linguagem.

Como dissemos em nossa Introdução, para a escolha do gênero, levamos em consideração as dimensões psicológicas, cognitiva, social e didática (SCHNEUWLY; DOLZ, 2014). Além disso, consideramos que a multimodalidade passou a estar cada vez mais presente nas nossas práticas sociais, justificando uma necessidade de pesquisas na área. Com base nessas questões, adotamos o gênero tutorial em vídeo para o trabalho com alunos adolescentes. Essa escolha mostrou-se bastante acertada, já que os alunos ficaram bastante motivados para produzirem os tutoriais em vídeo, tendo, inclusive, em um dos casos, optado por compartilhá-lo em uma rede social.

Para que o nosso objeto de estudo se tornasse instrumento de ensinoaprendizagem, foi necessário, assim, fazer uma análise do gênero, com fins didáticos, ou seja, elaborar seu modelo didático (MD). Em primeiro lugar, analisamos o próprio surgimento do gênero tutorial em vídeo. Em uma perspectiva interacionista social que concebe os gêneros como resultados de construções históricas e sociais, portanto dinâmicos, vimos que o gênero tutorial em vídeo mostrou essa fluidez dos gêneros, uma vez que surgiu como uma adaptação do manual de instruções e o ambiente e o seu uso propiciaram novas finalidades comunicativas codificadas através de elementos verbais e não verbais. Também, por essa razão, foi difícil encontrar outras pesquisas ou outras descrições e análises do gênero tutorial, já que se trata de algo bastante novo, quando realizado em vídeo. 
Para analisá-lo com fins didáticos, ou seja, para construir nosso MD, nos embasamos no quadro de análise da Semiótica Sociointeracional proposto por Leal (2010) em que a autora propõe a união do folhado textual do Interacionismo Sociodiscursivo (ISD) e as categorias da Gramática do Design Visual. A necessidade de nos basearmos nesse quadro veio do fato de que o modelo de análise do ISD privilegia uma análise de textos verbais e, no gênero tutorial em vídeos, precisaríamos analisar também os aspectos multimodais. Vimos que a escolha mostrou-se acertada, pois a partir desse quadro conseguimos analisar variados aspectos em relação ao contexto de produção, aos mecanismos enunciativos, linguísticos-discursivos e aos recursos imagéticos. No entanto, por se tratar de uma análise de vídeos, tivemos que adaptá-lo à nossa interpretação, já que neles a imagem é móvel. Ademais, no decorrer do nosso estudo, percebemos que algumas categorias propostas no ISD poderiam ser adaptadas para os gêneros multimodais: encontramos efeitos de corte e aceleração que funcionam como mecanismos de textualização, e índices não verbais de inserção de vozes observados nas roupas dos personagens, no cenário etc. Nesse sentido, podemos dizer que, tanto a adaptação do modelo da Semiótica Interacional ao gênero tutorial, que possui imagens móveis, quanto a proposta de categorias do ISD para a análise de vídeos são inovações de nossa pesquisa.

Após a construção do MD do gênero, pudemos construir a nossa sequência didática, pois a análise textual evidenciou variados aspectos do tutorial em vídeo a serem trabalhados em sala de aula. Vimos, de um modo geral, que os alunos desenvolveram significativamente as capacidades de linguagem, a saber: as de ação, as discursivas e as linguístico-discursivas. Esse desenvolvimento foi possível, pois a produção inicial evidenciou o desenvolvimento real dos alunos. Assim, pudemos adaptar a nossa sequência para atuar na ZPD dos alunos, ou seja, entre o espaço do que o aluno consegue fazer autonomamente e a na tarefa que o aluno faz com a ajuda de algo ou de alguém mais experiente. Esse foi um aspecto bastante interessante de nossa SD e de nossa pesquisa, pois pudemos, dentro das limitações contextuais em que nos encontrávamos, ou seja, utilizando algumas aulas de um curso ministrado por outro professor, em um contexto escolar específico, achar um ponto de encontro entre as atividades para trabalhar o gênero tutorial em vídeo e o programa esperado pela professora.

Questionamos, em alguns momentos, se a escolha do gênero foi apropriada, levando em consideração a sua complexidade, e nos perguntamos se, caso o trabalho 
realizado fosse com outro gênero, o desenvolvimento das capacidades de linguagem dos alunos teria sido mais significativo. No entanto, ao analisar as produções dos alunos, vimos que eles se engajaram bastante no trabalho proposto e, talvez, a motivação não tivesse sido a mesma se o gênero fosse outro: de fato, a motivação dos alunos para produzir o gênero tutorial em vídeo muito contribuiu com o desenvolvimento de suas capacidades de linguagem. Daí a importância de se levar em conta a dimensão psicológica na escolha do gênero a ser trabalhado com os alunos. O contato com gêneros variados de diversas práticas sociais é importante, pois possibilita aos alunos uma melhor relação com os textos, permitindo que as capacidades desenvolvidas em um gênero possam ser adaptadas a outro, e podemos equilibrar as dimensões psicológica, cognitiva, social e didática predominantes quando relacionadas a um gênero ou a outro. Além disso, a produção do gênero proporcionou aos alunos o contato com outros tutoriais em vídeos da escolha deles, uma vez que muitos alunos decidiram ensinar algo que não estava em seu domínio e, consequentemente, proporcionou uma aprendizagem de outros saberes, o que nos parece bastante pertinente em se tratando de uma pesquisa realizada em ambiente escolar. A produção de tutoriais em vídeo permitiu também um trabalho com outros tipos de atividade (atividade manual, no nosso caso) fatores importantes para a aprendizagem de outras habilidades do público com o qual trabalhamos. Esse fato é particularmente importante, pois consideramos que nossa sequência didática foi aplicada no espaço da escola e não de uma escola de línguas; portanto, a aprendizagem de outros saberes e de outras atividades é importante, pois é o próprio papel da escola.

Por fim, ainda que seja um gênero escolar, ou seja, objeto de ensinoaprendizagem, vimos que o tutorial em vídeo tornou-se novamente objeto de comunicação, uma vez que os alunos colocaram-no em suas práticas sociais, atingindo o principal objetivo do trabalho com gêneros: permitir agir no mundo social por meio da linguagem. Em outras palavras, transformamos o objeto de comunicação em objeto de ensino-aprendizagem, uma vez que estavam inseridos no espaço da escola; mas, os alunos o restituiram às práticas sociais, pois espontaneamente, ele voltou a ser objeto de comunicação.

Evidentemente, este estudo é apenas um ponto de partida para pesquisas futuras em relação aos gêneros emergentes no meio digital e suas implicações no ensinoaprendizagem de LEs, pois apesar de termos obtido, de um modo geral, um resultado significativamente positivo, sabemos que as turmas com as quais trabalhamos tinham 
um número reduzido de alunos. Dessa forma, se, por um lado, foi possível realizar o trabalho com cada aluno e em pequenos grupos, o que nos permitiu ter uma análise detalhada dos dados obtidos, por outro lado não pudemos testar nossa pesquisa com um número maior de participantes. Sendo assim, acreditamos que seria importante realizar uma pesquisa também com outros públicos e em grupos maiores.

$\mathrm{Na}$ verdade, a utilização de nossa SD sobre tutoriais em vídeo com outros públicos e com grupos maiores já está sendo posta em prática, pois, com as devidas modificações, ela já está sendo aplicada em um curso, em parceria com o Serviço de Cultura e Extensão da Faculdade de Filosofia, Letras e Artes da Universidade de São Paulo. Iniciado no ano de 2015, oferecemos o curso de Ateliers d'écriture et d'oralité à partir des genres textuels e, neste semestre, dentre os gêneros a serem trabalhados, selecionamos o gênero tutorial em vídeos. Com essa aplicação, poderemos ter uma ideia sobre como adaptar o trabalho com esse gênero para o público adulto e as modificações que isso demanda.

Gostaríamos, também, de apontar as contribuições que a nossa pesquisa traz para os estudos do ISD, do Grupo ALTER-AGE e do ensino-aprendizagem do francês como língua estrangeira. Primeiramente, ressaltamos a utilização de um gênero textual multimodal para o ensino é algo relativamente novo, fazendo com que nosso estudo seja pioneiro, pois é, segundo as pesquisas que realizamos em sites de busca, provavelmente, um dos primeiros estudos sobre o gênero textual tutorial e, também provavelmente, o primeiro sobre a língua francesa. Isso é válido não apenas para o estudo do gênero do ponto de vista contextual, discursivo e linguístico-discursivo, mas, sobretudo, para a reflexão sobre os gêneros emergentes e seu papel no ensino-aprendizagem de línguas por adolescentes, em um contexto de um local como a escola de aplicação.

Em seguida, como dissemos, parece-nos que alguns aspectos observados na nossa análise (efeitos de corte e aceleração que funcionam como mecanismos de textualização, e índices não verbais de inserção de vozes observados nas roupas dos personagens, no cenário etc.) são contribuições teórico-metodológicas da nossa pesquisa, pois a partir deles, percebemos que é possível fazer uma adaptação do folhado textual do ISD para os gêneros multimodais, enfatizando assim uma importância de dar continuidade a este estudo, em novas pesquisas, para propor, mais do que uma junção das categorias do ISD e da GDV, uma real discussão sobre as categorias do ISD aplicadas aos textos multimodais. 
Finalmente, salientamos que o tipo de informações paralelas trazidas para discutir o desenvolvimento das capacidades de linguagem, ou seja, a gravação em áudio da conversa dos alunos e o diário de bordo da professora são elementos importantes que ainda não tinham sido utilizados no Grupo ALTER-AGE para a compreensão da produção textual. Nesse sentido, ainda que o som das gravações não tenha permitido desenvolver muito esse aspecto, parece-nos importante trazer outras possibilidades de compreensão do desenvolvimento das capacidades de linguagem dos alunos, que podem ser seguidas em outras pesquisas; da mesma forma, o papel do diário de bordo foi semelhante e ambos podem ser desenvolvidos em outras pesquisas. 


\section{REFERÊNCIAS BIBLIOGRÁFICAS}

ABREU-TARDELLI, L. S. O chat educacional: o professor diante desse gênero emergente. In: DIONÍSIO, A. P.; MACHADO, A. R.; BEZERRA, M. A. Gêneros Textuais \& Ensino. 1 ed. São Paulo: Parábola Editorial, 2010. p. 95 - 104.

ARAÚJO, J. C. A conversa na web: o estudo da transmutação em um gênero textual. In: MARCUSCHI, L. A.; XAVIER, A. C., Hipertexto e_gêneros_digitais. 2ed. Rio de Janeiro, RJ: Editora Lucerna, 2005. p.91 - 109.

BARIONI, M. C. O ensino do francês na universidade: organização do currículo baseado em gêneros textuais. Universidade de São Paulo, USP, Brasil. 2010.

BAKHTIN, Mikhail. Estética da criação verbal. $2^{\text {a }}$ edição. São Paulo, Martins Fontes. 1953/1999.

BEZERRA, M. A. Ensino de língua portuguesa e contextos teóricos-metodológicos. In: DIONÍSIO, A. P.; MACHADO, A. R.; BEZERRA, M. A. Gêneros Textuais \& Ensino. 1 ed. São Paulo: Parábola Editorial, 2010. p. 39 - 50.

BRONCKART, Jean Paul. Interacionismo Sócio-discursivo: uma entrevista com Jean Paul Bronckart. Revista Virtual de Estudos da Linguagem - ReVEL. Vol. 4, n. 6, março de 2006. Tradução de Cassiano Ricardo Haag e Gabriel de Ávila Othero. ISSN 16788931 [www.revel.inf.br].

Les diferentes facetes de l'interactionnisme sócio-discursif.

Caleidoscópio, Unisinos, vol. 3, n. 3, p. 149 - 159, set/dez, 2005.

Os textos e seu estatuto - considerações teóricas, metodológicas e didáticas. In Bronckart, J.-P. Atividades de linguagem, textos e discursos. São Paulo: EDUC, 2012 [1999]. p. $69-89$. 
BRONCKART, J. P.; BOTA, C. Bakhtin desmascarado - história de um mentiroso, de uma fraude, de um delírio coletivo. São Paulo, SP: Parábola, 2012. 491p.

CRISTOVÃO, V. L. L. O ensino de leitura em língua estrangeira. In: ANJOSSANTOS, L. M., BEATO-CANATO A. P. M., CAMARGO G, P, Q. Gêneros textuais no ensino aprendizagem e na formação do professor de línguas na perspectiva interacionista sociodiscursiva. 1ed. Campinas, SP: Mercado das Letras, 2015, p. 19 63.

O gênero quarta capa no ensino de inglês. In: DIONÍSIO, A. P.; MACHADO, A. R.; BEZERRA, M. A. Gêneros Textuais \& Ensino. 1 ed. São Paulo: Parábola Editorial, 2010. p. 106 - 132.

DIONISIO, A. P. Multimodalidade discursiva na atividade oral e escrita (atividades). In: MARCUSCHI, L. A.; DIONISIO, A. P. (Org.). Fala e Escrita. Belo Horizonte: Autêntica, 2005.

DA COSTA, J. M. A. M., SANTOS, D. S. A leitura em sala de aula do gênero manual de instrução on-line e impresso. In: Congresso de leitura do Brasil, 17, 2009, Campinas. Anais do $17^{\circ}$ COLE, Campinas, SP: ALB, 2009. Disponível em: http://alb.com.br/portal.html. Acesso em 17 ago. 2016. ISSN: 2175-0939.

DOLZ, J., PASQUIER, A. BRONCKART, J.-P. "L'acquisition des discours: émergence d'une compétence ou apprentissage de capacités langagières diverses?" In: Etudes de Linguistique appliquée, 92, 1993. p. 23-37.

DOLZ, J. SCHNEUWLY, B. Genres et progression en expressionorale et écrite: éléments de réflexions à propos d'une expérience romande. Enjeux, $37 / 38$ :1996. p. 49 75.

Os gêneros escolares - das práticas de linguagem aos objetos de ensino. In: DOLZ, J., SCHNEUWLY, J. Gêneros orais e escritos na escola. 3 ed. Campinas, SP: Mercado das Letras, 2013 [2004]. p. 61 - 78. 
Pour un enseignement de l'oral : initiation aux genres

formels à l'école. Paris : ESF, 1998.

DOLZ, J., SCHNEUWLY, B., DE PIETRO, J. F. Relato de uma elaboração de uma sequência: o debate público. In: DOLZ, J., SCHNEUWLY, J. Gêneros orais e escritos na escola. 3 ed. Campinas, SP: Mercado das Letras, 2013 [2004]. p. 213 - 239.

DOLZ, J., SCHNEUWLY, B., HALLER, S. O oral como texto: construir um objeto de ensino. In: SCHNEUWLY, B.; DOLZ, J., Gêneros orais e escritos na escola. 3 ed. Campinas, SP: Mercado das Letras, 2013 [2004]. p. 125 - 155.

DOLZ, J., SCHNEUWLY, B., HALLER, S. ZAHNA, G. A exposição oral. In: SCHNEUWLY, B.; DOLZ, J., Gêneros orais e escritos na escola. 3 ed. Campinas, SP: Mercado das Letras, 2013 [2004]. p. 183 - 211.

Escola de Aplicação da Faculdade de Educação da Universidade de São Paulo. Disponível em: <www2.ea.fe.usp.br>. Acesso em: 27 Jul 2015.

FAZION, F. A elaboração de livro didático pelos professores de francês do Centro de Línguas do Estado do Paraná com uso de gêneros textuais: análise de uma experiência. Relatório de qualificação (mestrado) - Universidade de São Paulo, São Paulo, 2012.

FERREIRA, A. D. MELO, G. C. V. Análise de textos multimodais da Web e o ISD. DELTA [online]. 2016, vol.32, n.1, pp.1-21. ISSN 0102-4450. http://dx.doi.org/10.1590/0102-445056772752226428.

GUIMARAES-SANTOS, L. O gênero itinéraire de voyage para pensar o agir social no ensinoaprendizagem do FLE. Dissertação de mestrado. USP: São Paulo, 2012.

GORDO, Nívia. História da Escola de Aplicação da FEUSP (1976-1986): a contribuição de José Mário Pires Azanha para a cultura escolar. São Paulo: Faculdade de Educação da universidade de São Paulo, 2010. 201 p. Tese de doutorado, Faculdade de Educação da Universidade de São Paulo, São Paulo, 2010. 
HABERMAS, J. Théorie de l'agir communicationnel, volume I e II. Fayard: Paris, 1987

KRESS, G., VAN LEEUWEN, T. R. Reading Images - The Grammar of Visual Design. New York: Routledge, 2006.

LEAL, A. A. A organização textual do gênero Cartoon: Aspectos linguísticos e condicionamentos não linguísticos. Tese (Doutorado) - Universidade Nova de Lisboa, Lisboa, 2011.

LOUSADA, E. G. Elaboração de material didático para o ensino de francês. In: DIONÍSIO, A. P.; MACHADO, A. R.; BEZERRA, M. A. Gêneros Textuais \& Ensino. 1 ed. São Paulo: Parábola Editorial, 2010. p. 81-94.

LOUSADA, E. G. Entre o trabalho prescrito e realizado: um espaço para a emergência do trabalho real do professor. Tese (Doutorado) - Pontifícia Universidade Católica de São Paulo, São Paulo, 2006.

MELÃO, P.A. O gênero textual anúncio publicitário no ensino do FLE: o desenvolvimento da capacidade discursiva "argumentar" por meio de recursos verbais e visuais. Dissertação - Universidade de São Paulo, São Paulo, 2014. 311p.

OLIVEIRA, R. A. O fait divers no ensino: influências da sequência didática nas produções escritas de alunos de FLE. Dissertação - Universidade de São Paulo, São Paulo, 2014. 309 p.

SANTOS, T. F. S. A relação pensamento e linguagem no processo formativo do Mestrado. Tese - Universidade de São Paulo, São Paulo, 2016.

MARCUSCHI, L. M. Gêneros emergentes no contexto da tecnologia digital. In: MARCUSCHI, L. A.; XAVIER, A. C., Hipertexto e_gêneros_digitais. 2ed. Rio de Janeiro, RJ: Editora Lucerna, 2005. p.13 - 67.

NÖTH, W., SANTELLA, L. Imagem - Cognição, Semiótica, Mídia. 4 ed. São Paulo, SP: Iluminuras, 2009, 224 p. 
ROCHA, S. Coerções e liberdades textuais em francês como língua estrangeira: por um desenvolvimento do estilo na produção escrita por meio do gênero textual relato de viagem. Dissertação - Universidade de São Paulo, São Paulo, 2014, 310 p.

ROCHA, S. Prática da escrita criativa em FLE. Relatório de qualificação (mestrado) Universidade de São Paulo, São Paulo, 2012, 230 p.

ROJO, R., CORDEIRO G. S. Apresentação: gêneros orais e escritos como objetos de ensino : modo de pensar, modo de fazer.. In: DOLZ, J., SCHNEUWLY, J. Gêneros orais e escritos na escola. 3 ed. Campinas, SP: Mercado das Letras, 2013 [2004]. p. 61 -78 .

SANTIAGO, S. S., KRIEGER, M. G., ARAÚJO, J. O gênero tutorial e a terminologia das redes sociais. In: Filologia e língua portuguesa, Faculdade de filosofia, São Paulo, v. 16, n.2, p. $381 \quad-\quad 402$, 2014. Disponível em: http://www.revistas.usp.br/flp/issue/view/7282. Acesso em 17 ago. 2016. ISSN: 2176 9419.

SHANNON, C. WEAVER, W. The mathematical theory of communication. Urbana, University of Illionois Press, 1949.

SCHNEUWLY, B. Os gêneros e tipos de discurso: considerações psicológicas e ontogenéticas. In: SCHNEUWLY, B.; DOLZ, J., Gêneros orais e escritos na escola. 3 ed. Campinas, SP: Mercado das Letras, 2013 [2004]. p. 19 - 34.

UNIVERSIDADE DE SÃO PAULO. Regimento EAFEUSP. São Paulo, 2005. 33p.

VIGOTSKI, L. Pensamento e linguagem. Tradução de Jefferson Luiz Camargo. 2a ed. Martins Fontes: São Paulo, 1987 [1998].

Pensée et langage. Traduction de Francoise Seve. Paris: Dispute, 1997. 
VOLOSHINÓV, V. Le marxisme et la philosophie du langage. Paris : Les Éditions de Minuit, 1977. 


\section{ANEXOS 1 - Detalhamento dos tutoriais dos alunos}

\section{DETALHAMENTO DAS PRODUÇÕES DOS ALUNOS - PRODUÇÃO INICIAL - TURMA A}

Título do tutorial: Tuto de lait au chocolat

Duração: 1 min e $9 \mathrm{~s}$

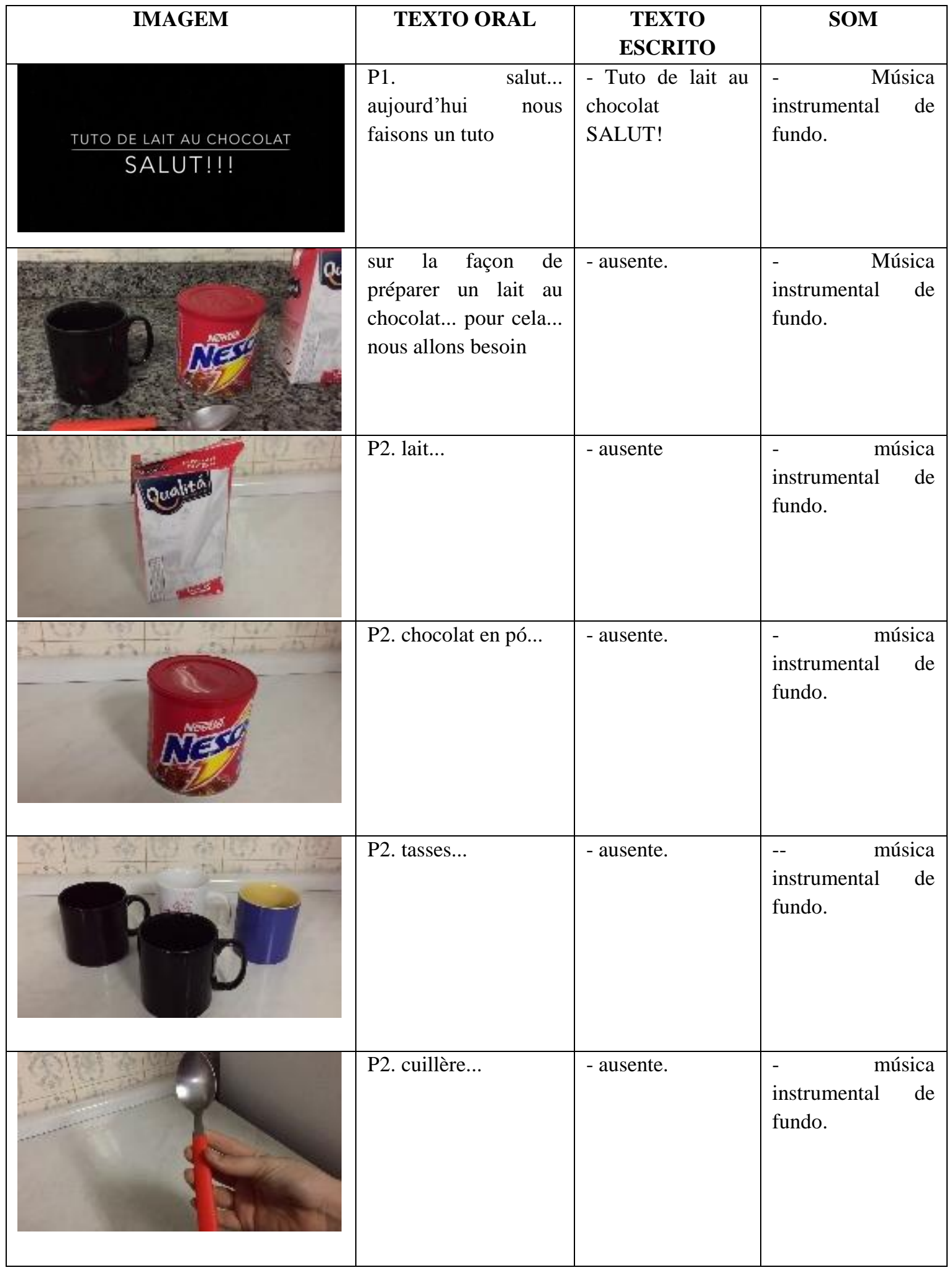




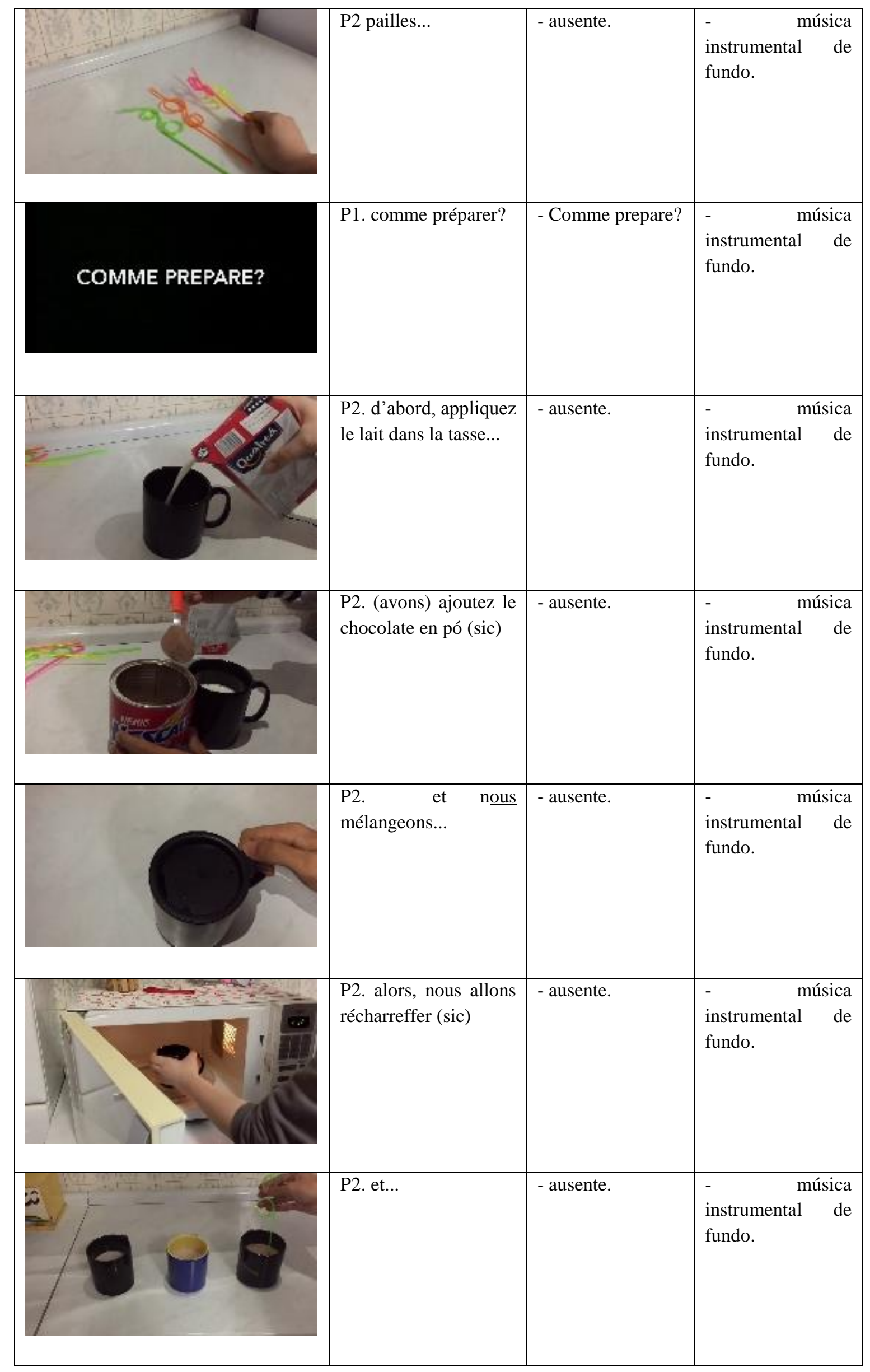




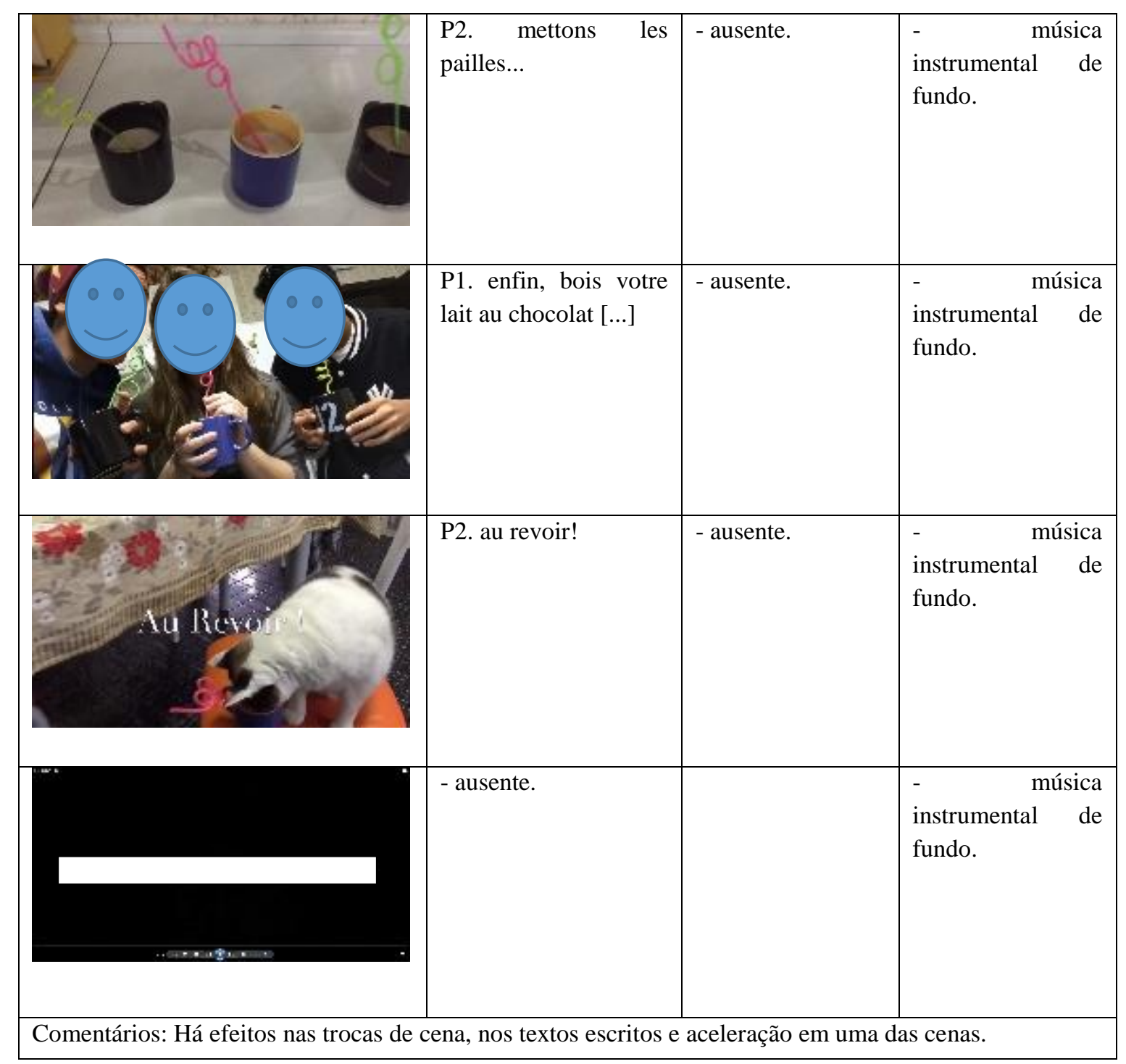

Título do tutorial: Tarte de bis

Duração: 1 min 53 segundos

\begin{tabular}{|c|c|c|c|}
\hline IMAGEM & TEXTO ORAL & $\begin{array}{c}\text { TEXTO } \\
\text { ESCRITO }\end{array}$ & SOM \\
\hline Tarte de Bis & - ausente. & - Tarte de bis. & - música de fundo. \\
\hline 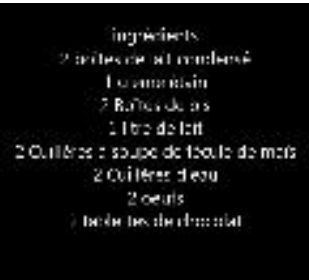 & $\begin{array}{l}\text { ingrédients } \\
2 \text { boîtes de lait } \\
\text { condensé } \\
1 \text { crème étaint } \\
2 \text { boîtes de bis } \\
1 \text { litre de lait }\end{array}$ & - ausente. & - música de fundo. \\
\hline
\end{tabular}




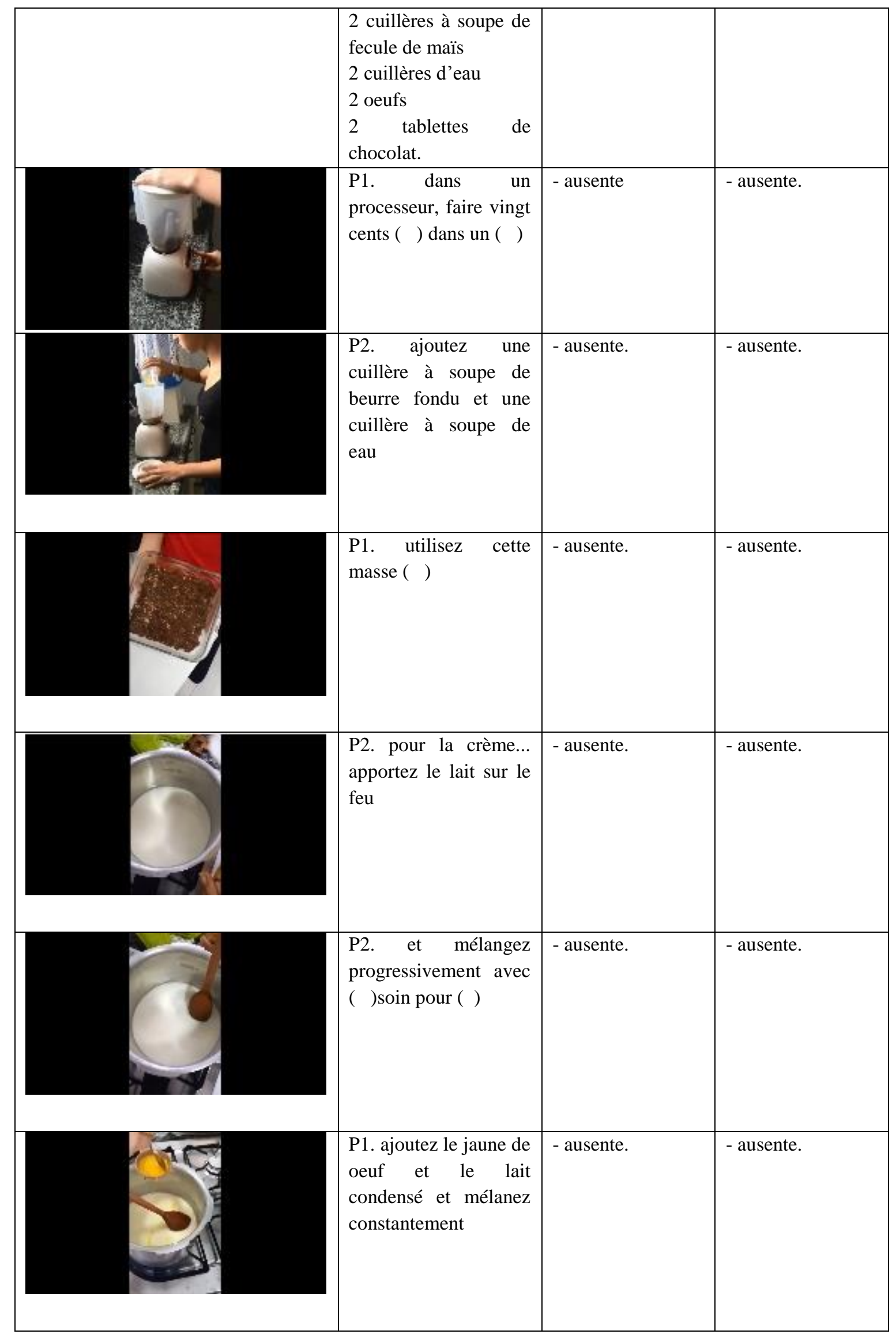




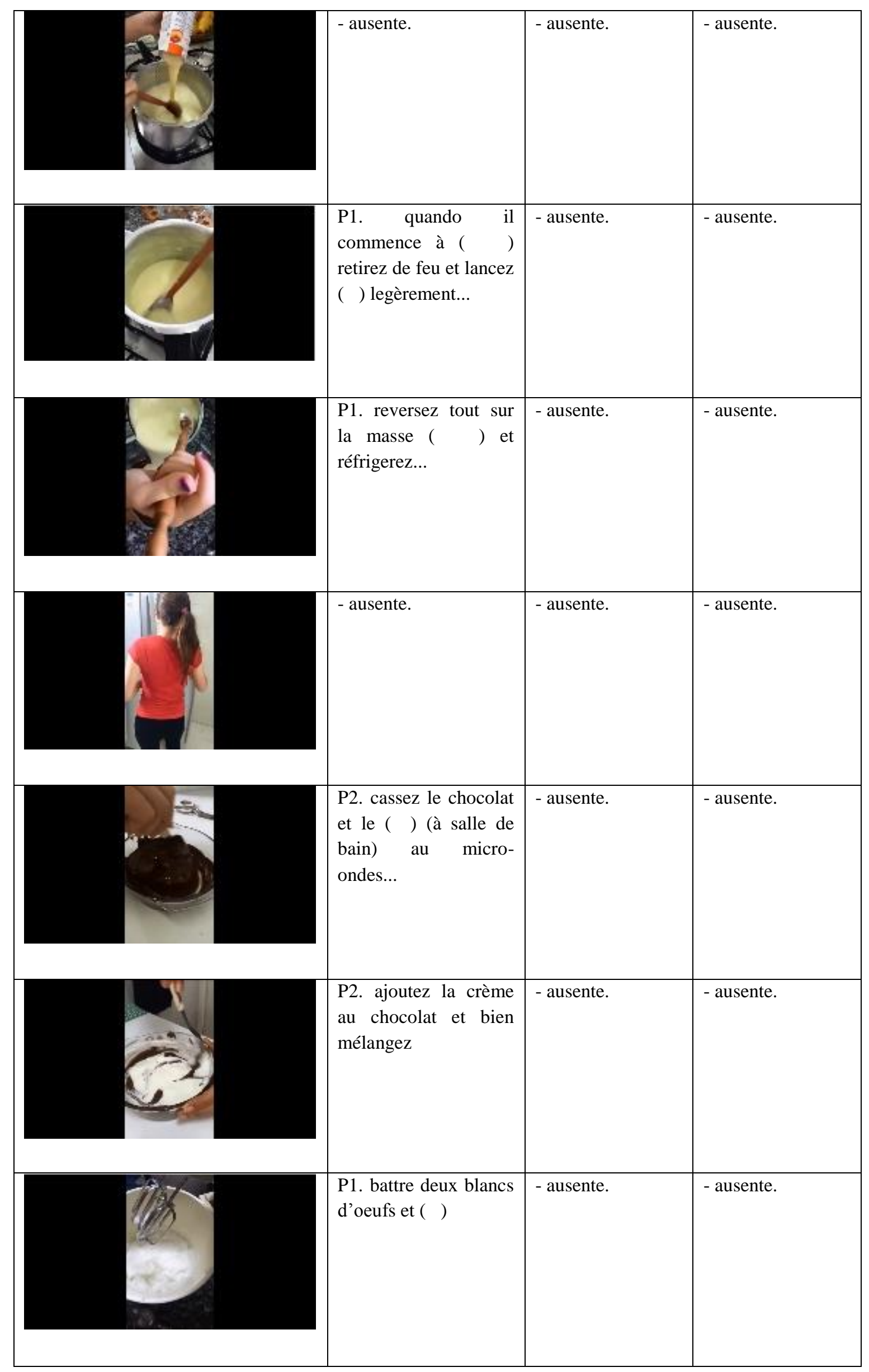




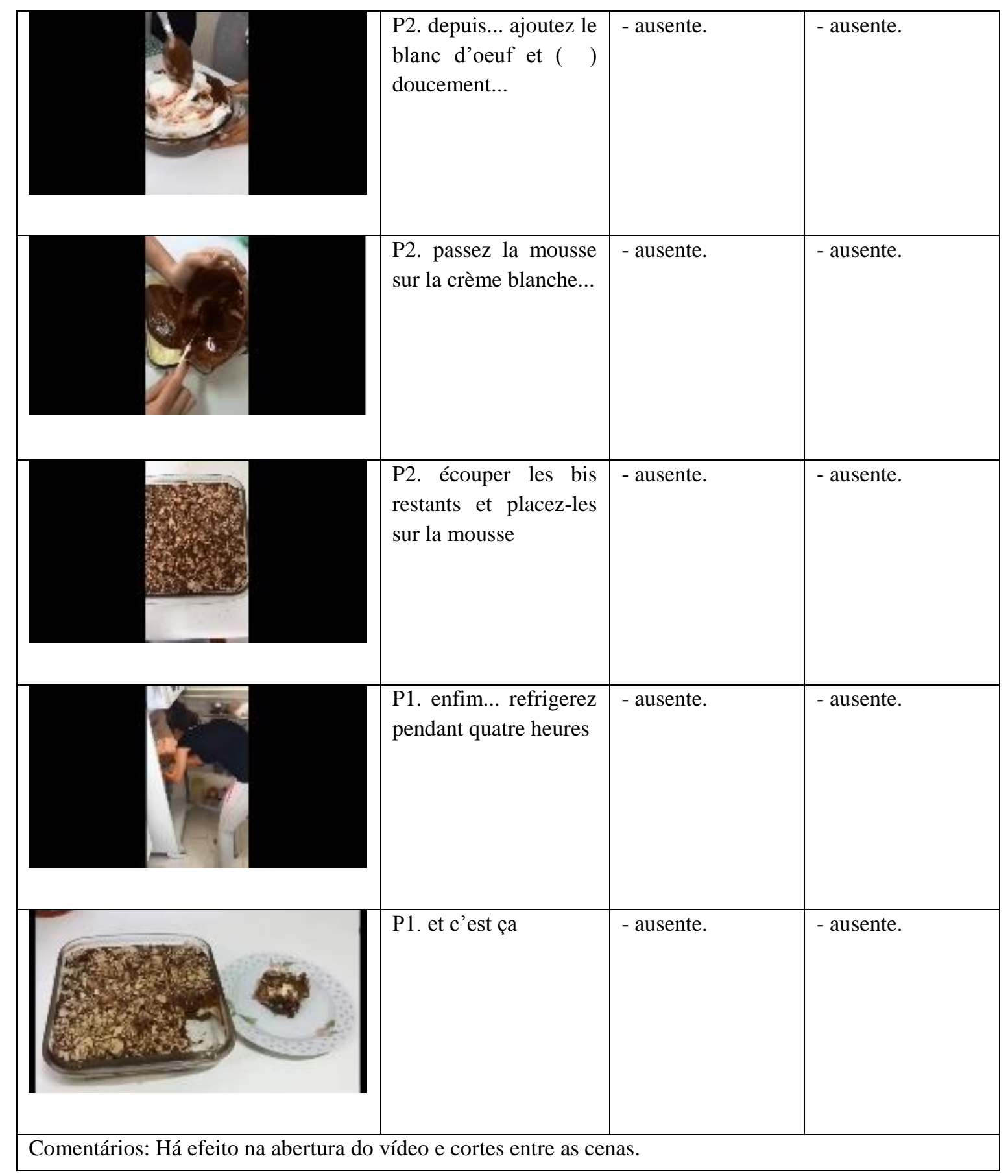

Título do tutorial: Brigadeiro

Duração: 1 min e 43 segundos.

\begin{tabular}{|c|c|c|c|}
\hline IMAGEM & TEXTO ORAL & $\begin{array}{c}\text { TEXTO } \\
\text { ESCRITO }\end{array}$ & SOM \\
\hline & $\begin{array}{l}\begin{array}{l}\text { P1. salut... } \\
\text { m'apelle }\end{array} \\
\text { P2. boujour... je } \\
\text { m'appelle } \\
\begin{array}{l}\text { P1. Nous allons } \\
\text { préparer la brigadeiro }\end{array}\end{array}$ & - ausente. & $\begin{array}{l}\text { - } r \text { música } \\
\text { instrumental de } \\
\text { fundo. }\end{array}$ \\
\hline
\end{tabular}




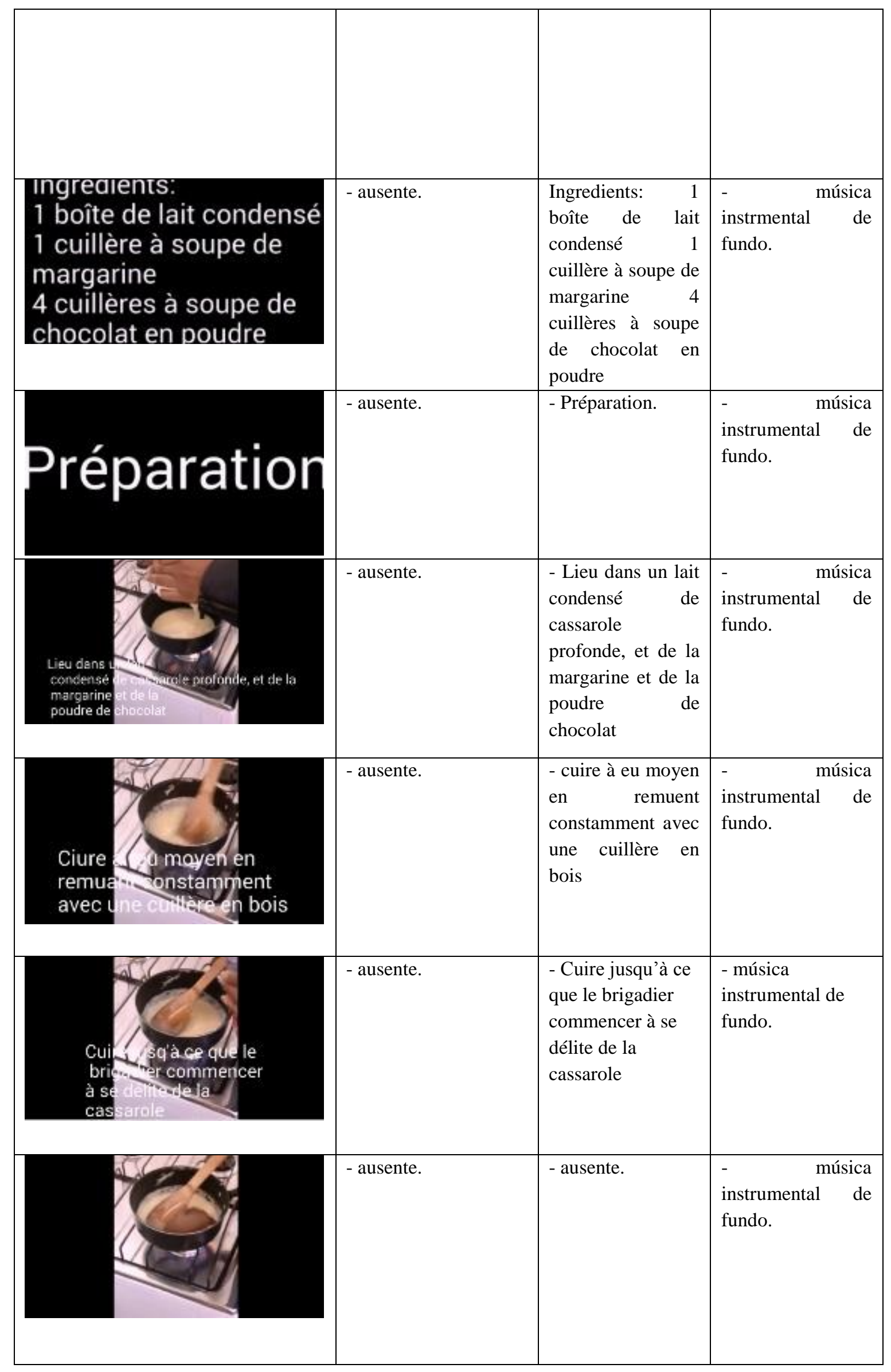




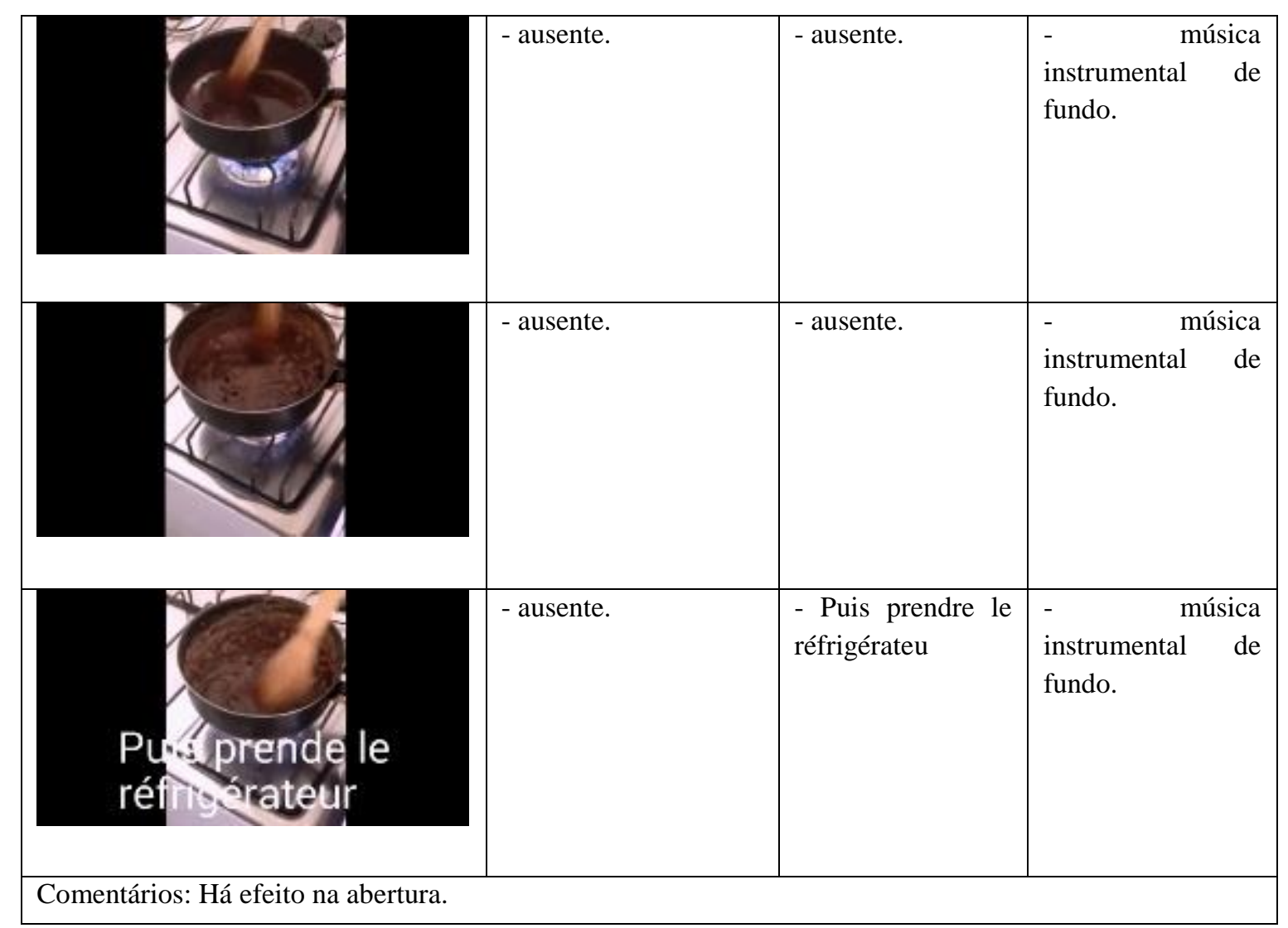

\section{DETALHAMENTO DAS PRODUÇÕES DOS ALUNOS - PRODUÇÃO FINAL - TURMA A}

Título: Tuto Pomo d'or

Duração: 2:07

\begin{tabular}{|c|c|c|c|}
\hline IMAGEM & TEXTO ORAL & $\begin{array}{c}\text { TEXTO } \\
\text { ESCRITO }\end{array}$ & SOM \\
\hline$\frac{\text { TUTO }}{\text { POMOD'OR }}$ & - ausente. & - Tuto Pomo d'or. & $\begin{array}{l}\text { - } \quad \text { música } \\
\text { instrumental de } \\
\text { fundo. }\end{array}$ \\
\hline & - ausente. & & $\begin{array}{l}- \\
\text { música } \\
\text { instrumental de } \\
\text { fundo. }\end{array}$ \\
\hline
\end{tabular}




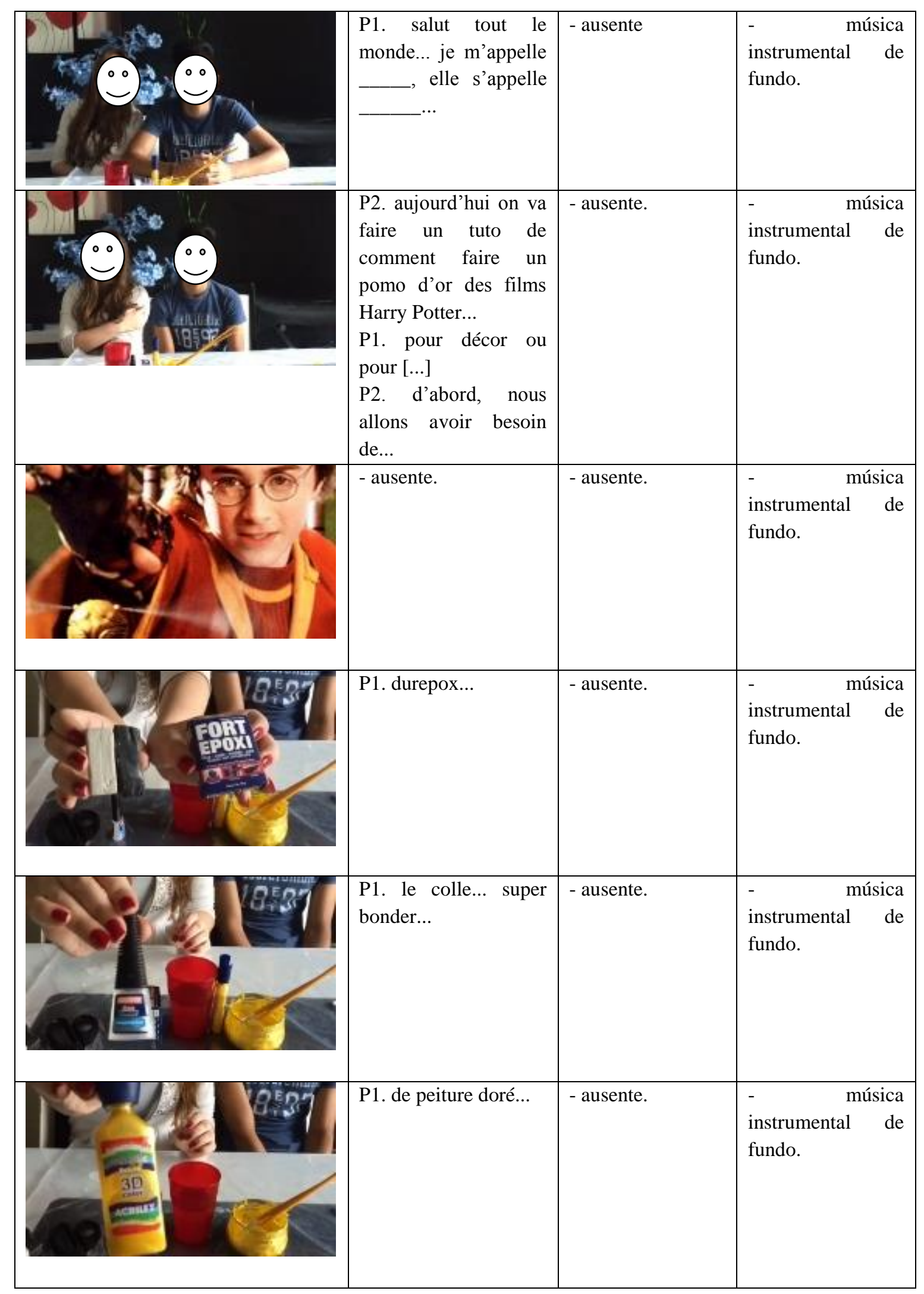




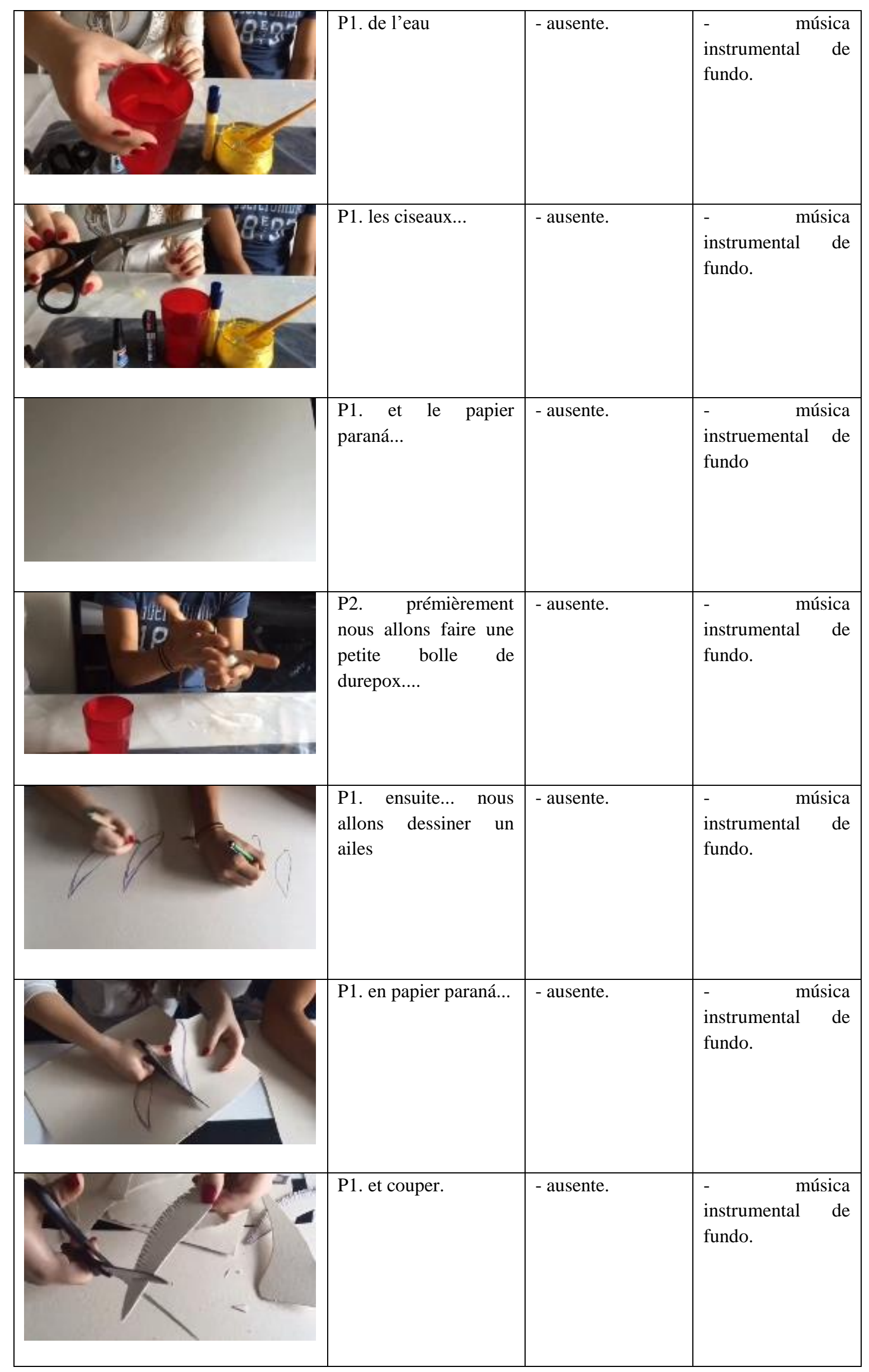




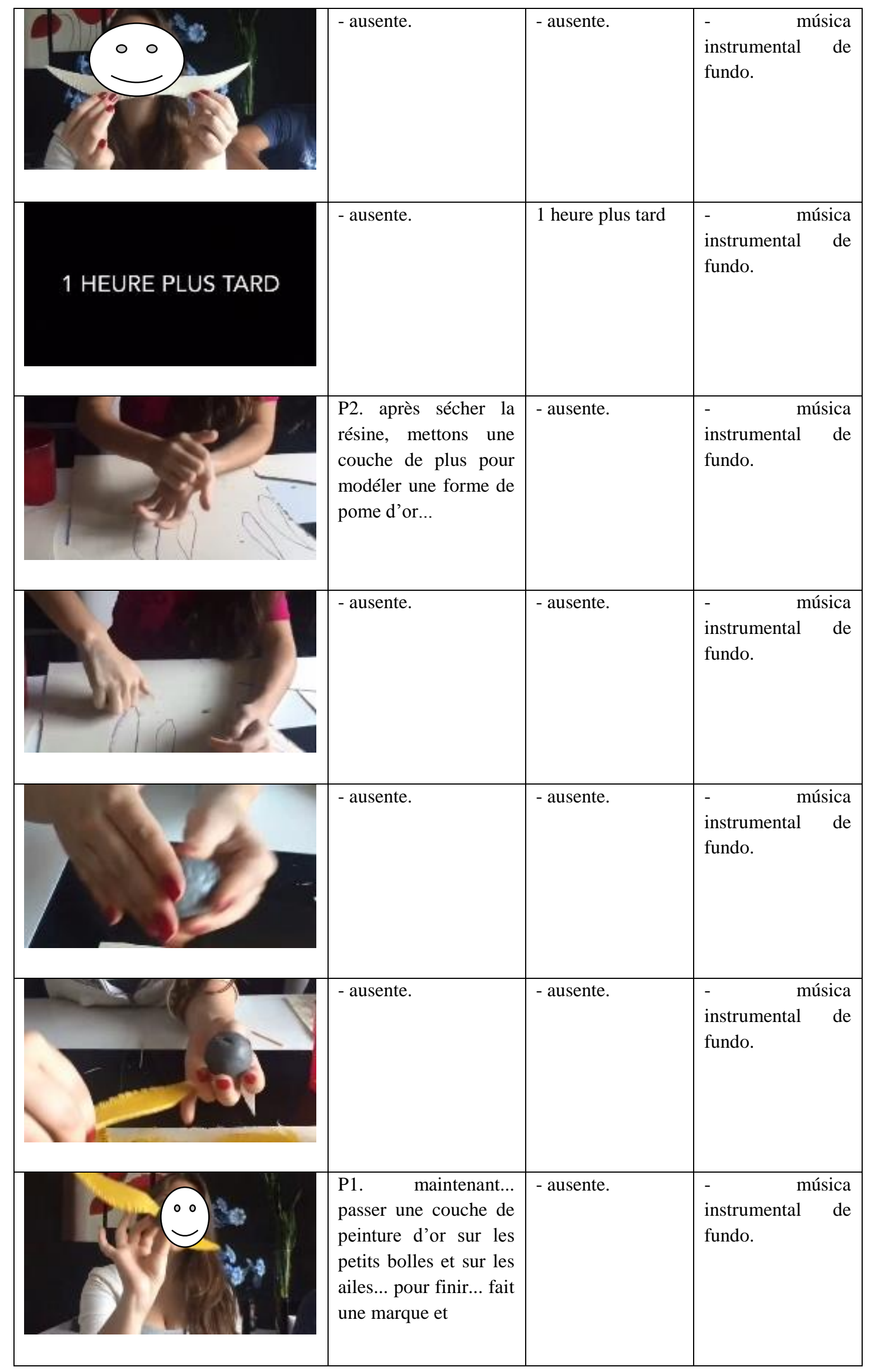




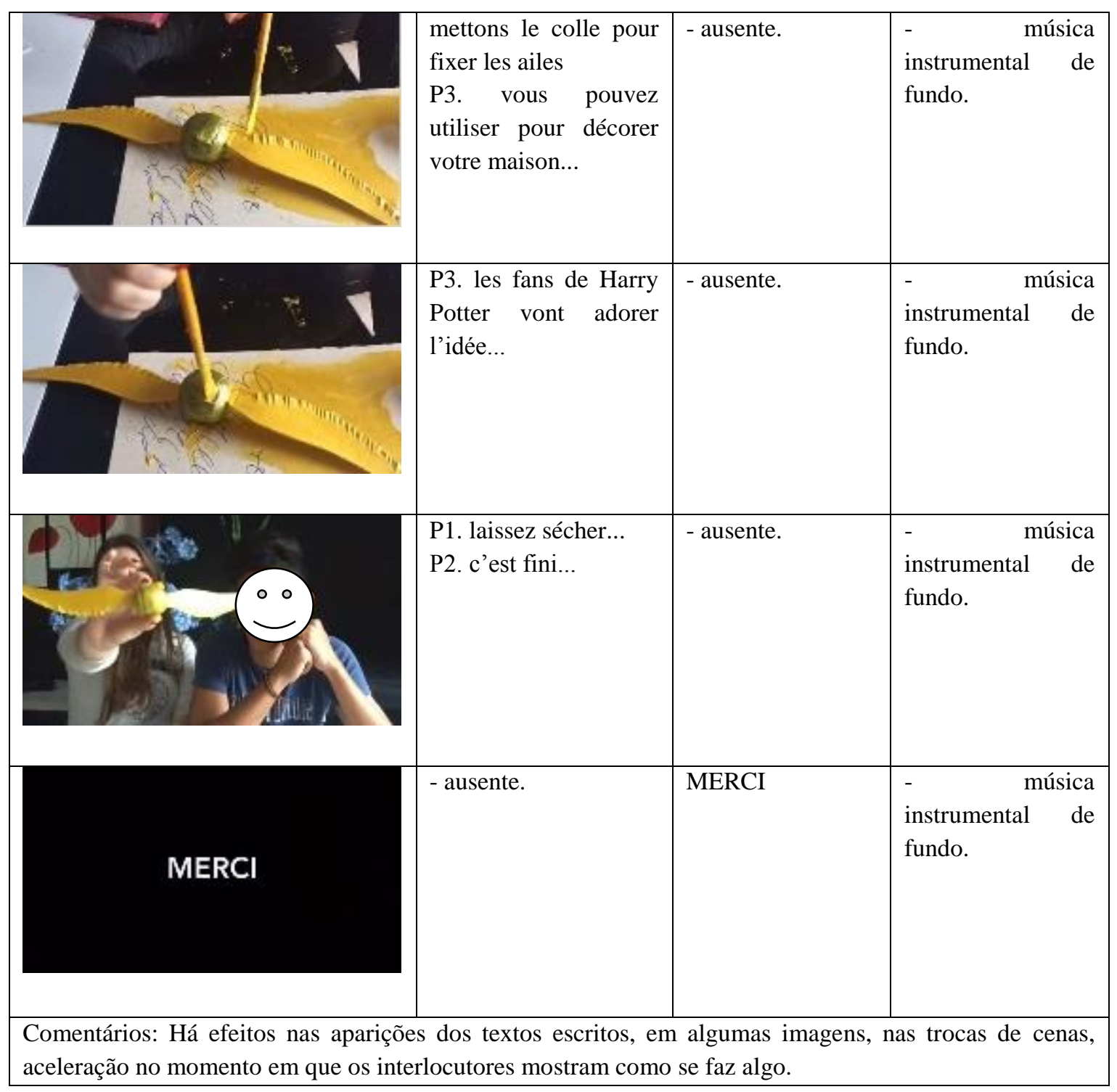

Título: Tye Dye

Duração: 1min 57 seg.

\begin{tabular}{|l|l|l|l|}
\hline \multicolumn{2}{|c|}{ IMAGEM } & \multicolumn{1}{|c|}{ TEXTO ORAL } & \multicolumn{1}{|c|}{ TEXTO } \\
ESCRITO
\end{tabular}




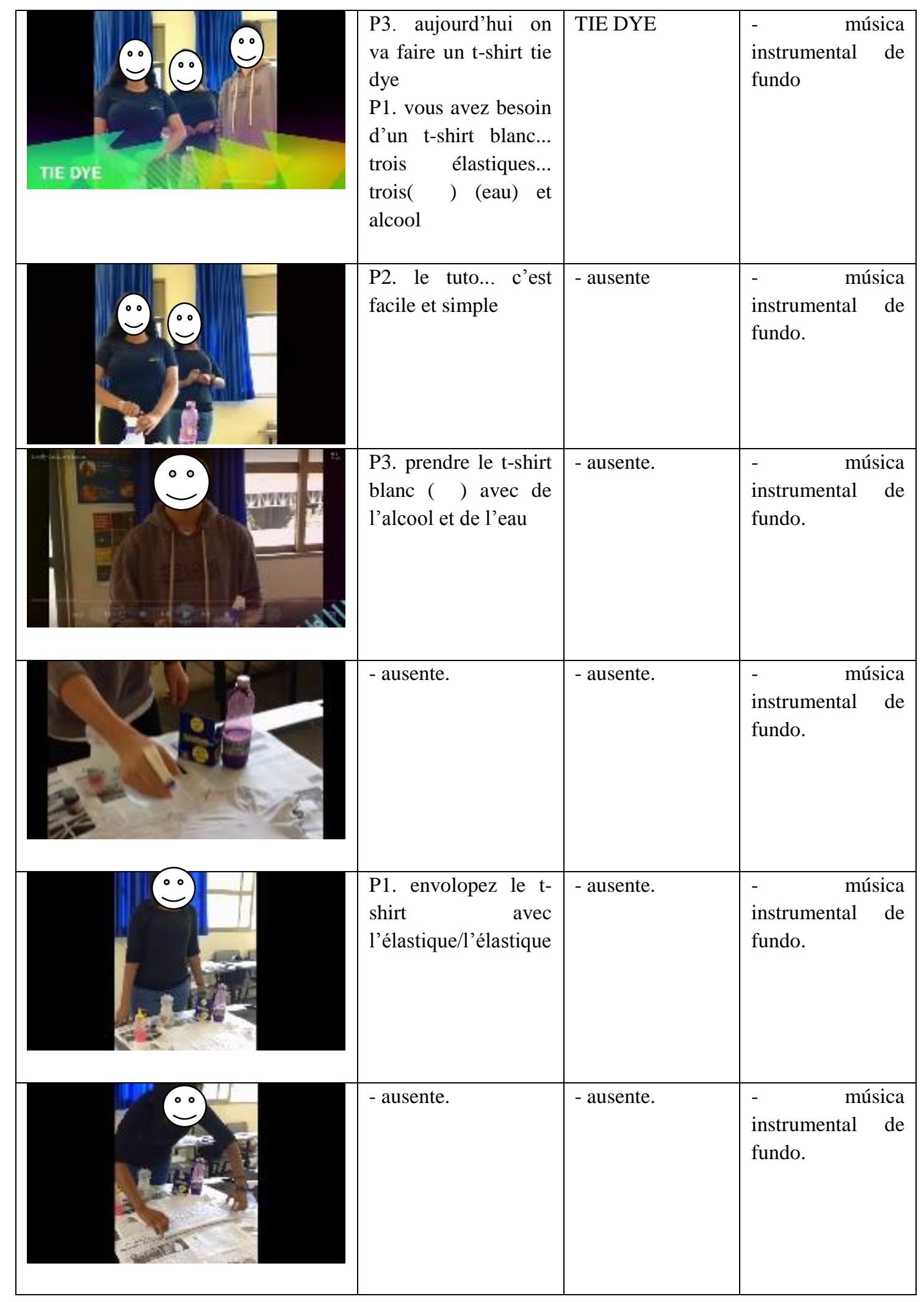




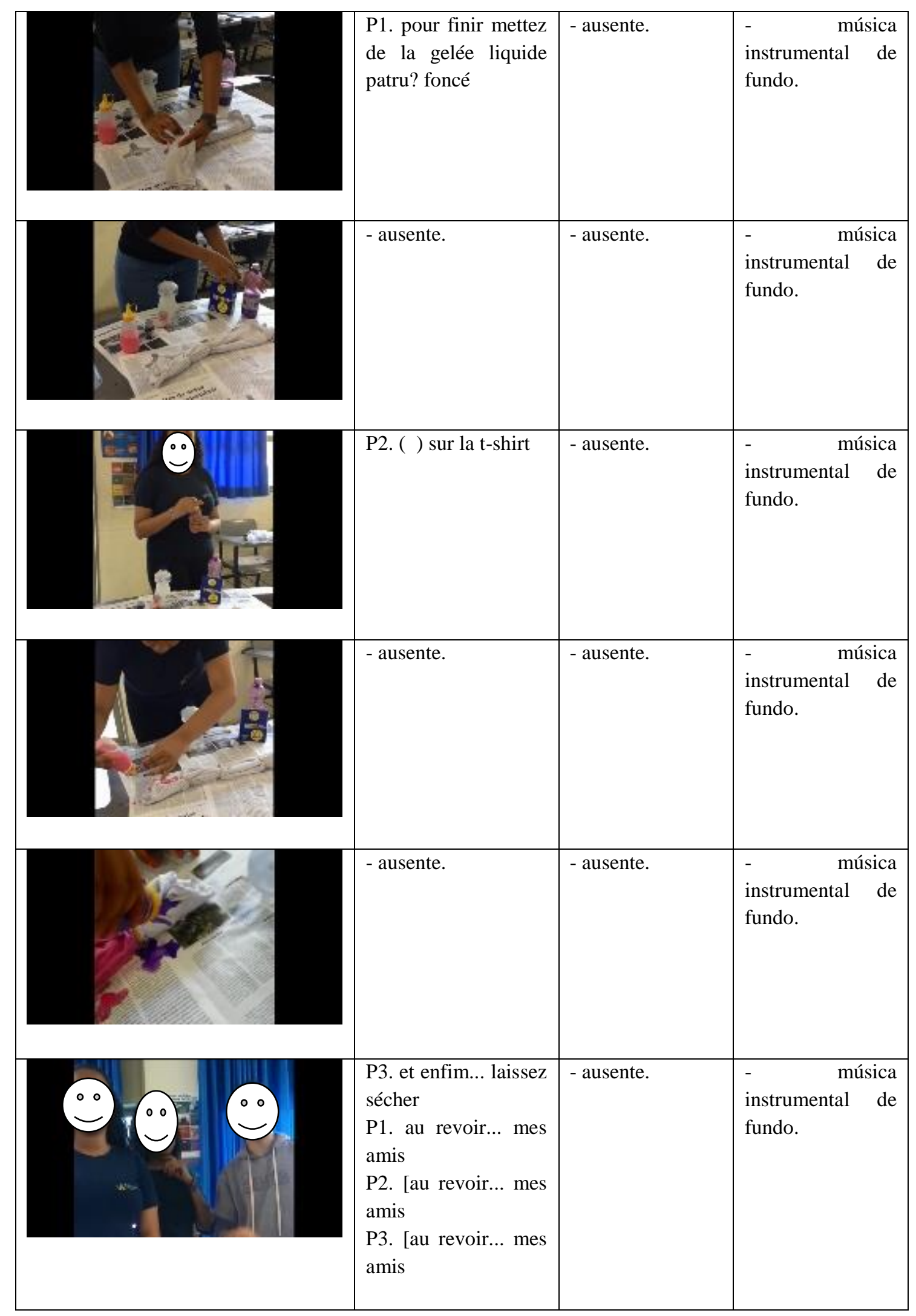




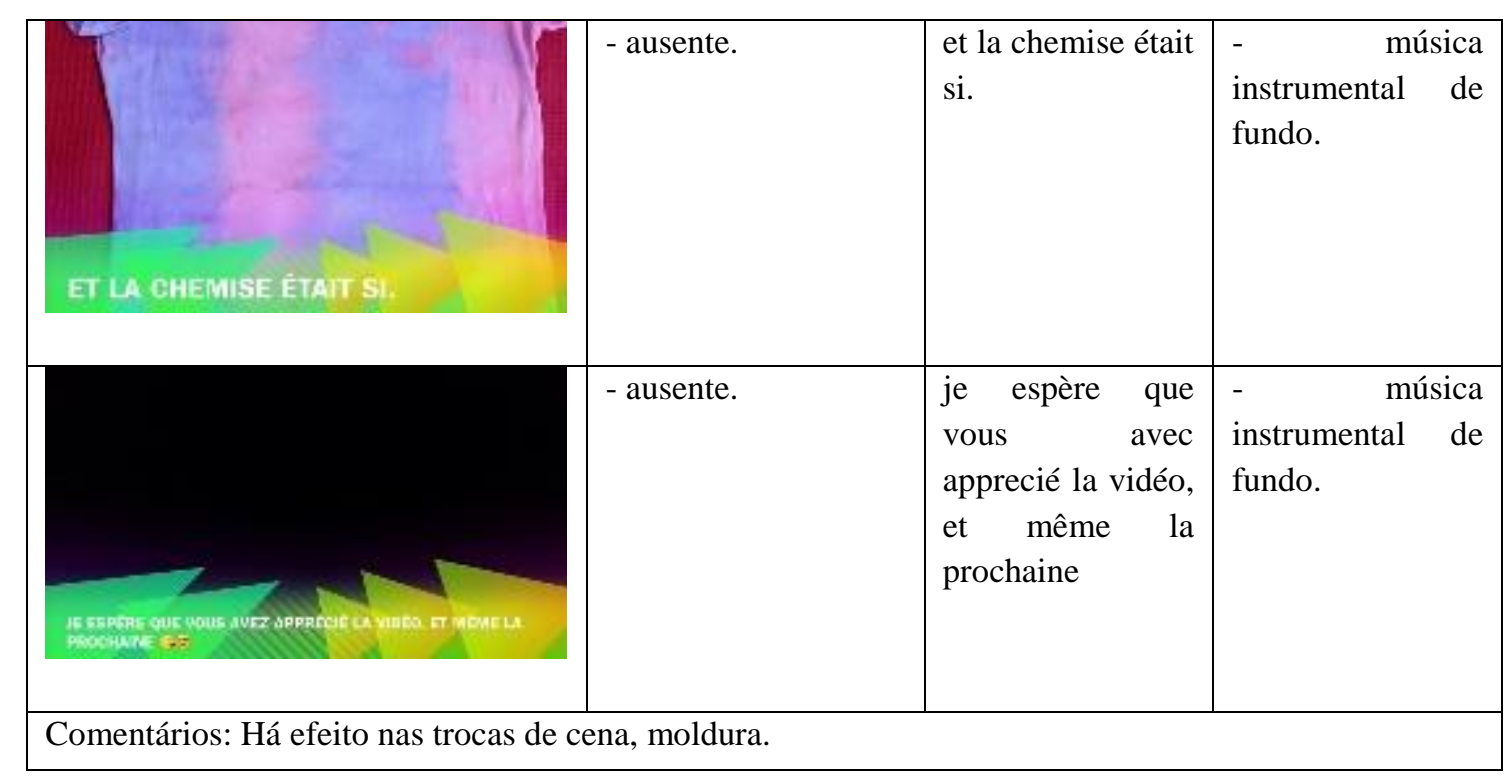

Título do tutorial: Tuto comme faire une poudre de couleur Duração:

\begin{tabular}{|c|c|c|c|}
\hline IMAGEM & TEXTO ORAL & $\begin{array}{c}\text { TEXTO } \\
\text { ESCRITO }\end{array}$ & SOM \\
\hline & - ausente. & $\begin{array}{l}\text { - Tuto de comme } \\
\text { feire une poudre } \\
\text { de couleur. }\end{array}$ & $\begin{array}{l}\text { - música de } \\
\text { fundo. }\end{array}$ \\
\hline & - ausente. & - ausente. & $\begin{array}{l}\text { - música de } \\
\text { fundo. }\end{array}$ \\
\hline & $\begin{array}{ll}\text { P1. bonjour... } & \text { je } \\
\text { m'appelle__ }\end{array}$ & - ausente & - ausente. \\
\hline 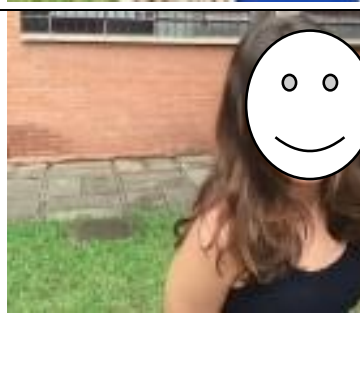 & $\begin{array}{l}\text { P2. je m'appelle } \\
\text { _... aujourd'hui } \\
\text { on va faire une } \\
\text { poudre colorié } \\
\text { seulement avec de } \\
\text { l'eau, du amidon de } \\
\text { maïs... et de colorant } \\
\text { alimentaire }\end{array}$ & - ausente. & - ausente. \\
\hline
\end{tabular}




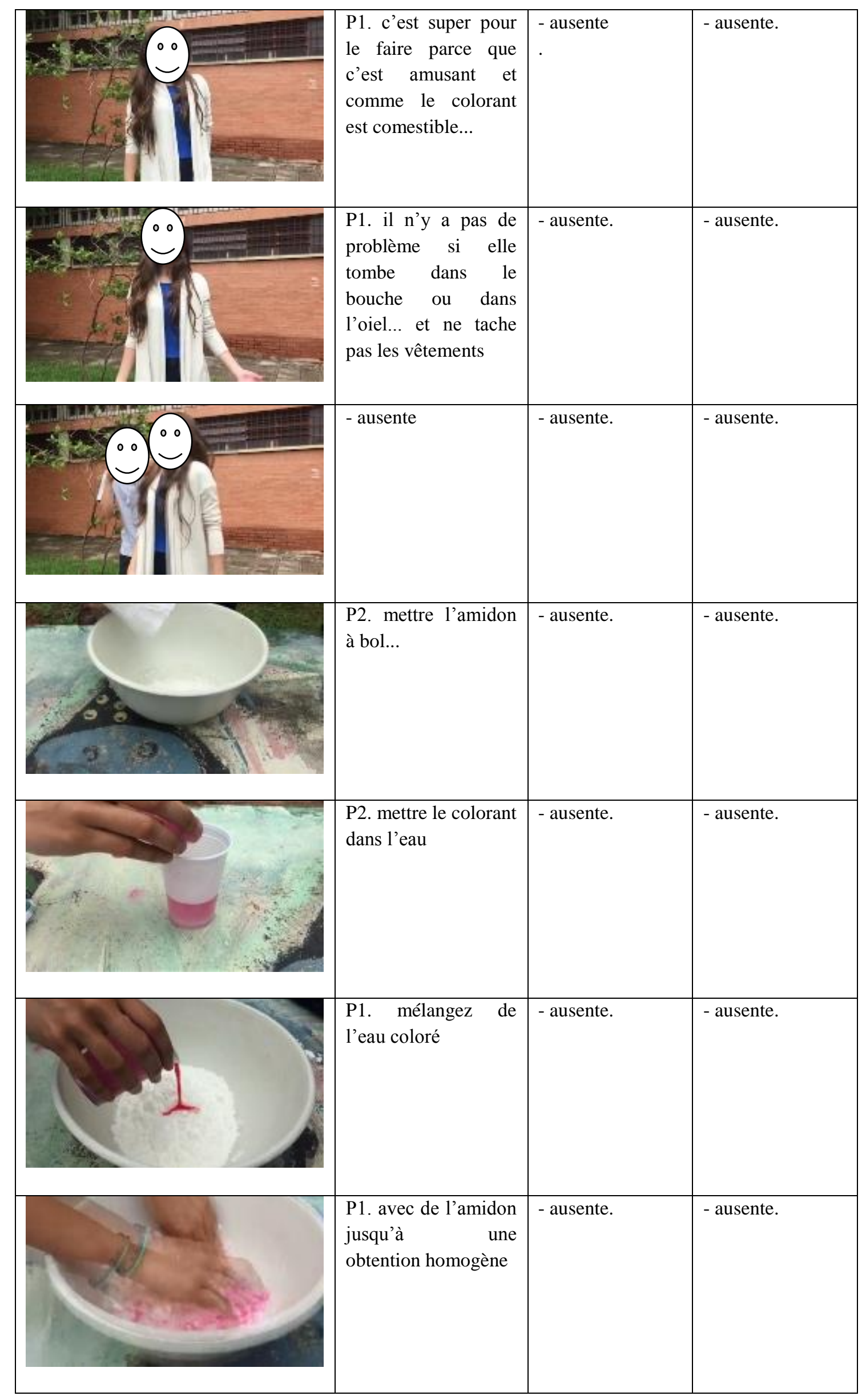




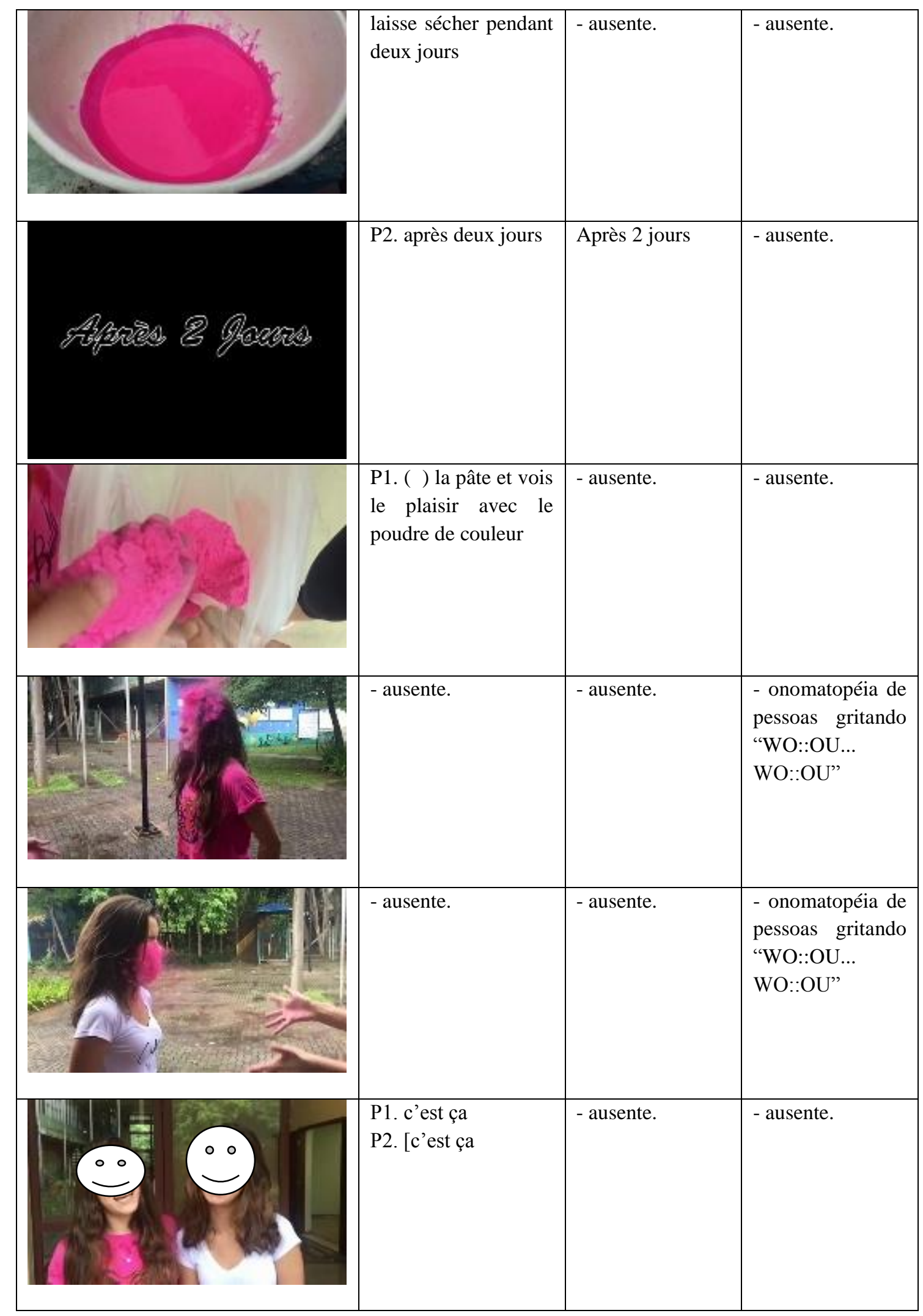




\begin{tabular}{|l|l|l|l|}
\hline & & - ausente. & música de \\
fundo. & \\
\hline & & & \\
\hline
\end{tabular}




\section{ANEXO 2 - Diário de bordo - Aline Hitomi Sumiya}

\section{1 de setembro de 2015}

\section{Aula - Turma A (1h40)}

Hoje iniciei a minha SD com a turma A. A Sahsha me apresentou para a turma e pediu para eu explicar um pouco da atividade para os alunos. Eu falei que faríamos uma atividade com vídeos, pois não queria estragar o effet surprise ${ }^{31}$ do gênero textual que trabalharíamos. Pedi para os alunos se apresentarem, pois ainda não sabia o nome deles e acho importante uma aproximação entre o aluno e professor. Eu não queria simplesmente chegar lá, fazer a atividade e ir embora. Pedi para eles me falarem um pouco do que eles gostam de fazer e do que não gostam. Depois que eles se apresentaram e disseram um pouco dos seus gostos, puxei um gancho dos gostos para as novas tecnologias. Perguntei se eles gostam de usar a internet, o celular etc. Todos disseram que utilizam a internet e redes sociais com bastante frequência. Eu preparei a atividade "Pour échauffer" 32 justamente para iniciarmos a discussão sobre as novas relações sociais que emergiram no contexto tecnológico. Fizemos a atividade e a maioria acrescentou um outro aplicativo, o chamado Snapchat. Os alunos me explicaram que é uma rede social em que você compartilha fotos. Podemos compartilhar com usuários específicos ou com todos os usuários que temos como amigo. Quando o amigo abre a foto, ela fica alguns segundos na tela e depois some. Caso o amigo tire um Print Screen ${ }^{33}$ da foto, o dono da publicação fica sabendo. Achei engraçado esse aplicativo e me fez refletir sobre o porquê de os usuários publicarem fotos que vão sumir em segundos. E porquê saber se alguém tira um Print Screen. Estou pensando em instalar no meu celular só para saber que tipo de fotos as pessoas postam e o porquê de fazer tanto sucesso entre os jovens. Quase todos da turma disse que tem esse aplicativo! Depois de discutir sobre as redes sociais, entramos no assunto tutorial. Eu tentei fazer uma atividade que começasse de um tema maior e que fosse afunilando para o gênero textual que vamos produzir (tecnologia>internet>redes sociais> o que fazemos nas redes sociais> aprendemos algo nas redes sociais?> o quê, onde?> tutorial). Achei que ficou bem legal na interação em sala de aula. Os alunos assistiram os vídeos da atividade "Pour rentrer dans le sujet " ${ }^{\text {34 }}$ com bastante atenção e senti que eles ficaram bem empolgados em produzir um tutorial. No geral, achei que a turma foi bem receptiva comigo. Eu já tive experiência em sala de aula com crianças, adultos (de todas as idades, inclusive da terceira idade), mas a minha única experiência com adolescentes foi na época do estágio supervisionado da graduação que foi na escola pública. Em comparação com as turmas que já tive (adultos e crianças), achei que aquele primeiro mal à l'aise 35 passou rápido e os alunos falavam as coisas sem ter muita vergonha. Reparei que os alunos tem um pouco de dificuldade de falar em francês. Grande parte das discussões eram feitas em português. Imagino que seja pelo pouco contato com a língua, pois eles tem uma aula de $1 \mathrm{~h} 50$ por semana e de certa forma, eles são obrigados a fazerem um língua estrangeira moderna.

03 de setembro de 2015

\footnotetext{
${ }^{31}$ Efeito surpresa.

${ }^{32}$ Para aquecer, aquecimento.

${ }^{33}$ Capturar a tela.

${ }^{34}$ Para entrar no tema.

${ }^{35}$ Mal estar, desconforto.
} 


\section{Aula - Turma B (1h40)}

Hoje teve aula com a segunda turma. Eu tentei repetir a aula e explicar melhor algumas coisas que eu não deixei muito claro na aula com a outra turma. Os alunos foram bastante receptivos também. Achei engraçado, uma aula antes, os alunos tiveram aula de artes e chegaram com o rosto todo pintado. As discussões fluíram e reparei que eles foram um pouco mais focados que a outra turma de alunos na última atividade. Fiquei impressionada também com as ideias de tutorial deles. Todos os grupos da outra turma falaram que vão apresentar um tuto cuisine $e^{36}$, ao passo que nessa turma, vi que eles planejaram montar um skate, ensinar a desenhar e receita vegana.

\section{Atendimento - turma A}

À tarde ofereci atendimento aos alunos da turma A. Um aluno da outra turma apareceu e ficou conversando comigo sobre o tutorial que ele vai fazer. Ele gosta muito de desenhar e vai fazer um tutorial ensinando a desenhar um rosto. Mais três alunos foram, mas eles não tinham definido nada específico. Falaram de receitas, mas ficaram preocupados em afinar o violão. Acabou o meu tempo de atendimento e eu não pude ajudar muito os alunos. Mas fiquei feliz de ter aparecido 4 alunos. Isso demostra um interesse nas atividades.

\section{8 de setembro de 2015}

\section{Apresentação dos tutoriais produzidos - Turma A (30 min)}

Hoje foi o dia da apresentação das produções dos alunos. 2 grupos apresentaram (total de 4 grupos). De certa forma, entendo que foi difícil fazer uma produção de um vídeo em uma semana. Antes das apresentações, pedi para os alunos falarem um pouco de como foi a produção, quem fez, como fizeram, quem gravou etc. Percebi que a grande preocupação dos alunos tem sido a edição do vídeo. Eles acham que para se fazer um bom vídeo, é necessário, somente, saber editar. Diante disso, vi que posso trabalhar várias coisas observadas no modelo didático, tanto nos elementos verbais como no não verbal. Fiquei sabendo que a turma B não vai poder apresentar a produção na quinta feira, pois eles vão ter os jogos da escola. Assim, eles vão apresentar no dia 17. Eu fiquei triste, pois vou ter que iniciar o Modulo $1 \mathrm{com}$ base, somente, nas duas produções da turma de hoje. Queria poder ver melhor as dificuldades dos alunos.

\section{5 de setembro de 2015}

\section{Aula - Turma A (1h50)}

Hoje iniciamos o primeiro módulo da SD. Eu havia programado assistir as produções dos alunos que ainda não haviam apresentado (2 grupos no total) e fazer as atividades da sequência. No entanto, a professora da turma precisava dar alguns recados sobre os próximos eventos e atividades da escola e isso levou mais ou menos trinta minutos da aula. Dos grupos que faltavam apresentar, uma dupla fez e o trio não fez a primeira produção.

Assistimos a produção de duas alunas. Eu pedi para elas comentarem um pouco sobre como foi realizado o tutorial, quem gravou, quais foram os problemas etc. As duas alunas

\footnotetext{
${ }^{36}$ Tutorial de cozinha.
} 
disseram que foi fácil fazer o vídeo, mas tiveram problemas com o áudio e por isso, colocaram legenda em algumas partes do vídeo. Elas apresentaram um tuto cuisine de brigadeiro.

Depois da apresentação, iniciamos a SD. A primeira parte tinha como objetivo fazer uma atividade de compreensão oral. Apesar de os alunos não conseguirem falar muito bem, percebi que eles não tem muita dificuldade na compreensão oral. As falas do vídeo são rápidas e a caixa de som não estava muito boa. Fiz a parte dos partitivos com os alunos, mas não deu tempo para fazer a atividade que eu havia programado para usar o conteúdo. Acho que eles já estavam dispersos para ver a gramática, mas não tinha como trocar a ordem das atividades, pois a última atividade (Pour bien expliquer le processus de préparation... ${ }^{37}$ ) trabalhava tanto os organizadores cronológicos quanto os partitivos.

\section{Atendimento para a turma B}

À tarde me propus a dar atendimento para a turma $\mathrm{B}$, pois eles vão apresentar a primeira produção na quinta-feira próxima. Eu havia combinado de ficar das $14 \mathrm{~h}$ às $15 \mathrm{~h}$, mas como os alunos chegaram às 14h30, decidi ficar até às 15h30. Fiquei feliz, pois 4 alunos apareceram. Um deles é da outra turma, mas apareceu lá para ajudar os colegas com a gravação. O curioso é que esse aluno que foi ajudar na gravação faz parte do trio que não fez a primeira produção da outra turma. Um dos alunos decidiu fazer a produção sozinha, pois ele queria fazer um tutorial de desenho. Orgulhoso, ele me mostrou sua pasta de desenhos. Achei interessante acompanhar o momento da produção do vídeo. Bernardo, o aluno dos desenhos disse para Leo, aluno da outra turma: "Filma só a minha mão!". Leo: "Mas você não tem que se apresentar antes? Você tem que aparecer!". Bernardo: "Nos tutoriais que eu vi, não aparece o rosto da pessoa, pelo menos os de desenho!". Achei interessante, pois os dois observaram como iniciar um tutorial e as suas variações. O Bernardo tem bastante facilidade na língua francesa. Ele fez algumas anotações, tirou algumas dúvidas de vocabulário comigo e gravou sem ler o papel! Isso me deixou bastante impressionada. Os dois outros alunos, Marina e Leo, estavam desmontando um skate, pois eles decidiram apresentar um tutorial de como montar um skate. Depois eles me perguntaram sobre o vocabulário relativo à skate. Eu disse que não sabia, mas que muito provavelmente, assim como no Brasil na França deve ser em inglês também. Reparei que os alunos usam muito o Google tradutor no celular. É difícil explicar como eu tiro dúvidas sobre vocabulário. Normalmente, quando tenho dúvidas, eu jogo a palavra em Google imagens, leio textos para ver a utilização da palavra etc. Mas eu sempre procuro usando o note. Procurar as coisas no celular não é muito fácil.

Às $15 \mathrm{~h} 30$ eu precisava ir embora. Comuniquei os alunos e a Marina e o Leo disseram que ficariam mais à vontade para gravar o vídeo sem que eu estivesse na sala.

\section{7 de setembro de 2015 (1h20)}

Hoje foi o dia das apresentações da primeira produção dos vídeos tutoriais pelos alunos. No início da aula, a professora da turma precisou dar uns recados, como na turma anterior. Pelo que percebi, a escola e/ou a professora promove várias atividades interessantes em que os alunos entram realmente no universo francês. Em uma das atividades, a professora vai levar os alunos para uma Boulangerie française ${ }^{38}$. Lá eles vão poder tomar o café da manhã tipicamente francês. Essa atividade vai ser no horário da aula, assim, os alunos não perderão a aulas das

\footnotetext{
${ }^{37}$ Para explicar o processo de preparação.

${ }^{38}$ Boulangerie française.
} 
outras disciplinas. Outra atividade interessante que a professora comentou foi a Journée des $a_{d o s}{ }^{39}$. A Journée des ados ocorre uma vez por semestre e os alunos dos Centros de Estudo de Línguas (CEL) são convidados a participar também. Acho interessante essa aproximação com outras escolas em que os alunos terão contato com outros brasileiros que falam francês.

Depois dos recados, a professora me deixou um pouco sozinha para iniciar as apresentações. Antes, eu comentei com os alunos sobre eles serem privilegiados de poder participar de atividades como o Petit déj à la boulangerie française e a Journée des ados. Comentei que eu não tive essa oportunidade na minha escola, aliás, eu não tinha nem mesmo o contato com a língua francesa. Sobre as apresentações, fiquei feliz, pois com exceção de um aluno, todos os outros apresentaram. $\mathrm{O}$ outro aluno não estava presente na primeira aula e eu disse que ele poderia trazer a primeira produção na próxima aula. Os temas dos tutoriais foram bastante variados: tivemos como desenhar com rosto, como fazer um bolo vegetariano, como montar um skate e como fazer um porta livros. Dois grupos levaram as atividades em um pendrive e os outros dois, já haviam publicado no grupo de francês do Facebook! Achei interessante, pois esse é o objetivo dos tutoriais: publicá-los em alguma rede social e as pessoas que visualizam os vídeos, podem comentar e "curtir" os vídeos. Com isso, tive a ideia de na última produção, pedir para os alunos publicarem neste mesmo grupo e os outros vão reagir aos vídeos. Assim, a situação de produção será a que ocorre como nas práticas sociais. Eles vão produzir um vídeo autêntico! Estou empolgada. Um grupo fez também Les erreurs d'enregistrement ${ }^{40}$. Foi bem engraçado e deu para observar um pouco mais sobre o processo de produção dos alunos: eles se prepararam/ ensaiaram para a apresentação. Outra coisa que percebi, sem analisar minimamente os vídeos, foi que na maioria dos tutoriais houve grande influência da língua inglesa. No ensino fundamental II, mais especificamente no $7^{\circ}, 8^{\circ}$ e $9^{\circ}$ ano, os alunos estudam três línguas estrangeiras: o francês, o inglês e o espanhol. E no $9^{\circ}$ ano, eles optam por uma língua para estudar nos três anos do Ensino Médio. Fico me perguntando como eles serão quando adultos! Depois das apresentações, iniciamos a SD. Eu não queria iniciar a SD depois das apresentações, pois imaginava que os alunos estariam cansados de ver vídeos tutoriais, mas por conta do tempo (na última aula os alunos tiveram os jogos da EAFAUSP) não tive muita escola, pois eles já estavam atrasados em relação à outra turma. O que eu temia aconteceu. Na hora de iniciar a SD, eles mal prestavam atenção. Fizeram a atividade de compreensão, mas comparando com a outra turma, que observou minimamente o vídeo proposto, deu para perceber que esta turma não fez. Na próxima aula, retomarei um pouco os conteúdos para dar continuidade à SD.

\section{2 de setembro de 2015 Aula - Turma A (50 min)}

Hoje dei continuidade a minha sequência com a turma A. Eu estava com a impressão de que a turma B tinha mais empatia comigo, mas depois da aula de hoje, as coisas mudaram. Eu iniciei a aula com uma recapitulação dos partitivos. Eu perguntei para um dos alunos: “__ dis-moi. Qu'est-ce que tu a mangé aujourd'hui dans le petit déjeuner?" "41 Ele me respondeu: "J'ai mangé gâteau" " Eu escrevi a frase no quadro e pedi para eles se lembrarem da aula passada em que vimos que quando a quantidade não é expressa na frase, devemos usar o

\footnotetext{
39 Jornada dos adolescentes. Na língua francesa, se tem o costume de falar só uma parte das palavras, assim "ados" é adolescent.

${ }^{40}$ Erros de gravações.

41، __ diga-me. O que você comeu hoje no café da manhã?"

42 "Eu comi bolo". No português a frase está correta. No francês, no entanto, quando não se exprime a quantidade (eu comi uma fatia de bolo, por exemplo), utiliza-se o partitivo.
} 
partitivo. A frase ficaria então "J'ai mangé du gâteau" "43. Assim, eu fui perguntando para outros alunos sobre o que eles haviam comido até completar o quadro com todos os exemplos da regra ( $d u$, de la, de l', des). Depois disso iniciamos a atividade. Pedi para que eles fizessem um meio círculo com as carteiras e já senti que eles ficaram animados. Iniciamos a atividade “Aujourd'hui, je vais manger..." ${ }^{44}$ e foi muito divertido. Na primeira vez, eu permiti que eles anotassem no caderno, mas na segunda eu ressaltei que faríamos de memória. Senti que isso os deixou animados e a concentração melhorou. Fizemos a atividade dos organizadores cronológicos e também foi muito boa! Todos fizeram e diferentemente da outra aula que eles estavam mais sérios, nessa eu vi muitos sorrisos!

\section{4 de setembro de 2015}

\section{Turma B - Aula}

Hoje dei continuidade ao módulo I da turma B. Essa turma estava uma atividade da sequência atrasada em relação à outra. Nós fizemos o quadro dos partitifs e as atividades. Em comparação com a outra turma, senti que eles estavam menos focados naquele dia, acho que devido ao calor. Fizemos a atividade de demi-ronde e como eu senti que eles não estavam conseguindo formar as frases, falei para eles que na segunda rodada, dividiríamos o grupo em dois. Mas uma aluna me disse: "ah, mas tá tão legal assim". Então deixei o grupo grande mesmo. No final, os alunos começaram a se apropriar da estrutura gramatical e na última atividade, a maioria já estava usando corretamente.

\section{7 de outubro de 2015}

\section{Turma A - Aula}

Hoje tivemos a aula com o título "pour bien expliquer ce qu'on doit faire..." ${ }^{45}$. No início de cada aula, a professora responsável da turma, coloca os pontos que serão vistos na aula e l'agenda ${ }^{46}$ para as datas importantes como entrega de trabalhos, provas etc. Neste dia, em especial, a professora me enviou uma mensagem dizendo que chegaria um pouco atrasada e pediu para que eu iniciasse a aula sem ela. Escrevi as informações no quadro e conversei um pouco com os alunos: na aula seguinte, eles foram à uma padaria francesa como atividade da aula de francês. Tentei puxar o assunto para que eles respondessem utilizando o partitivo, pois havíamos feito uma atividade com este conteúdo durante a sequência. Iniciamos a atividade que visava o imperativo no francês. Primeiramente eles visualizariam um tutorial e em seguida, responderiam as questões. No entanto, a escola estava sem a caixa de som e tivemos que faze-la sem o vídeo inicial, achei uma pena. A atividade do Yoga insolite ${ }^{47}$, foi criada para que os alunos utilizassem o imperativo. Eu perguntei aos alunos se eles já haviam feito yoga e todos disseram que não. Eu disse então que faríamos uma atividade diferente. Pedi para que eles se levantassem e eu fui dando as coordenadas em francês: Levantem o braço esquerdo, dobre a perna direita, fechem os olhos etc. Depois pedi para um dos alunos ser o "professor de yoga" e repetimos o processo.

\footnotetext{
43 "Eu comi 'do' bolo"

${ }^{44}$ Hoje eu vou comer...

${ }^{45}$ Para explicar bem o que se deve fazer...

${ }^{46}$ Agenda.

${ }^{47}$ Yoga diferente.
} 
Em seguida, tivemos a atividade dos focos de cinema. Apesar dos alunos dominarem certos aspectos da imagem, achei importante colocar na sequência para ser tema de discussão. Para finalizar a aula, fizemos a atividade Pour montrer que le tuto est intéressant... ${ }^{48}$. Ela tinha como objetivo, mostrar algumas formas diferentes de se iniciar e finalizar um tutorial. Evidentemente, salientei aos alunos que temos variadas formas de se iniciar e finalizar um tutorial, isso vai depender muito da criatividade deles, mas que dependendo do objetivo, como por exemplo, conquistar seguidores, a forma que eles articulam o discurso poderá ajuda-los a atingir o objetivo esperado. A turma foi dividida em grupos e eu pedi para que eles imaginassem que fariam um tutorial (exemplos dados na atividade) e eles deveriam pensar no início e no final do tutorial. Após elaborar o texto, deveriam apresentar para a turma e por fim, votar no grupo que fez o melhor texto e a melhor apresentação. Um dos grupos colocou uma música no momento da apresentação. A atividade ficou bem legal!

Para finalizar a aula, fizemos a ficha de auto avaliação e os alunos iniciaram a discussão da última produção. Infelizmente, não deu para discutir muita coisa, então pedi para Sahsha, vinte minutos da outra aula para que os alunos conseguissem elaborar melhor o texto.

\section{9 de outubro de 2015 - turma B}

A aula com esta turma tinha os mesmos objetivos da aula do dia 27 com a outra turma: explicar como fazer alguma coisa; mostrar como se faz alguma coisa (focos de cinema); mostrar que o tutorial é interessante; fazer a ficha de auto avaliação e por fim, iniciar a produção final. No entanto, a Sahsha comentou comigo que os alunos teriam que sair no meio da aula para uma atividade de espanhol, uma exposição da outra turma sobre o dia dos mortos. Por essa razão, só conseguimos fazer até a atividade de mostrar que o tutorial é interessante. Esta atividade foi muito bem realizada, pois senti que os alunos se engajaram bastante para a realização da tarefa.

\section{3 de novembro de 2015}

\section{Aula (20 min)}

Neste dia tivemos vinte minutos para a discussão dos tutoriais. Aproveitei para gravar a conversa dos alunos e ajuda-los a delimitar o tema da produção deles. Muitos utilizaram a internet no celular para procurar ideias e para ver como se faz alguma coisa. Uma questão preocupante é o uso que eles fazem com bastante frequência do Google tradutor. Eu pedi para que eles evitassem de usá-lo, pois a tradução acaba ficando estranha e, muitas vezes, agramatical.

\section{Atendimento}

$\mathrm{Na}$ parte da tarde, ofereci atendimento aos alunos das duas turmas para ajuda-los na produção final. Apareceram seis alunos. Um grupo decidiu fazer um pó para festa Holi. Nesta festa, modinha nos dias de hoje, as pessoas se pintam com esse pó. O outro grupo, decidiu fazer um enfeite do filme Harry Potter e o outro aluno, decidiu fazer um tutorial de desenhos japoneses, ele se interessa muito pela língua e cultura japonesa.

Observei algumas coisas interessantes sobre o processo de produção deles: eles preferiram, com exceção do último aluno, escolher algo que eles acham interessante, mesmo

\footnotetext{
${ }^{48}$ Para mostrar que o tutorial é interessante...
} 
sem saber fazer, olhar o tutorial de como se faz, aprender a fazer para depois, ensinar a fazer. Outra coisa que observei é que eles não olharam os tutoriais em francês (talvez pela dificuldade na língua) o que facilitaria no vocabulário da produção. Eles olhavam os tutoriais em português, anotavam os materiais necessários e algumas informações sobre o modo de fazer e depois, fizeram o texto em francês. É claro que o texto não estava pronto, uma vez que eles precisariam adaptar com a filmagem, mas fizeram grande parte no atendimento.

\section{5 de novembro de 2015}

\section{Aula (20 min)}

Neste dia eu fui para escola de aplicação para fazer com os alunos a ficha de auto avaliação, somente, pois esta turma está um pouco atrasada em relação ao conteúdo e a Sahsha me disse que não teria muito tempo. Fizemos a ficha e eu salientei aos alunos que temos uma grande variedade de estilos nos tutoriais e que tentamos trabalhar alguns aspectos importantes. Pedi para eles seguirem a ficha para a elaboração da última produção, pois facilitará na hora de lembrar as capacidades vistas durante a sequência. Infelizmente não tivemos tempo de iniciar a última produção, pois como havia dito, o tempo estava apertado para essa turma.

10 de novembro de 2015

\section{Apresentação da produção final}

Hoje os alunos apresentaram a produção final dos vídeos tutoriais. Antes de cada apresentação, eu pedi para que os alunos comentassem como fizeram os vídeos, os textos, a filmagem etc. A conversa foi gravada para que eu possa analisar melhor. No total tivemos três grupos de três alunos. Ainda não analisei os vídeos, mas vi que os alunos utilizaram alguns aspectos das sequências e os tutoriais ficaram melhor elaborados. Como última atividade, pedi que os alunos publicassem os vídeos no grupo da turma no Facebook. Esse grupo é foi feito pela professora de francês com o intuito de compartilhar informações sobre as aulas e sobre a língua francesa no geral e as publicações só podem ser visualizadas pelos integrantes do grupo. Esta última atividade será muito interessante, pois o gênero será veiculado no seu real local de interação, as redes sociais. Pedi também para que os alunos comentem os vídeos dos colegas, curtam, se achar interessante etc.

\section{Atendimento para o grupo B}

Neste dia ainda, ofereci atendimento para o grupo B. Um aluno compareceu, o aluno que tem interesse pela língua e cultura japonesa. Ele me falou que gostaria de fazer um vídeo tutorial sobre a língua japonesa. Fiquei na dúvida se os vídeos veiculados na internet sobre língua, expressões francesas, por exemplo, podem ser considerados tutoriais. Eu diria que são vídeo aulas, pois não se ensina a fazer algo. Perguntei a ele se ele não havia pensado em algum outro tema e ele comentou sobre o tutorial de desenho. Falei com ele que talvez fosse melhor a segunda opção, pois nesse caso, ensina-se a fazer algo. Preciso refletir sobre.

19 de novembro de 2015

Apresentação das produções finais - grupo B

Hoje os alunos apresentaram as produções finais. Antes de cada apresentação, pedi para os alunos comentarem sobre a produção, como fizeram o texto verbal, onde gravaram, os problemas durante a produção etc. Quatro grupos apresentaram: um grupo apresentou um tuto 
origami, outro, sobre maquiagem e tivemos 2 trabalhos individuais, um de como baixar músicas no celular e outro, de como desenhar olhos no estilo manga. Uma dupla não apresentou, mas vão publicar diretamente no face. Alguns alunos já haviam publicado os vídeos no grupo da turma no Facebook, mas pedi para os que ainda não publicaram, para posta-los e comentar os vídeos dos colegas. 